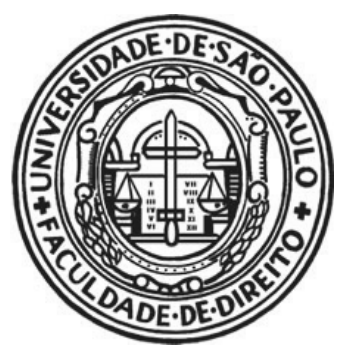

UNIVERSIDADE DE SÃO PAULO

FACULDADE DE DIREITO

Talitha Viegas Borges

DIREITO À VERDADE E JUSTIÇA DE TRANSIÇÃO: A COMISSÃO DE ACOLHIMENTO, VERDADE E RECONCILIAÇÃO DE TIMOR-LESTE (2002-2005)

Dissertação de Mestrado

Orientadora: Professora Associada

Cláudia Perrone-Moisés 


\section{DIREITO À VERDADE E JUSTIÇA DE TRANSIÇÃO: A COMISSÃO DE ACOLHIMENTO, VERDADE E RECONCILIAÇÃO DE TIMOR-LESTE (2002-2005)}

Dissertação apresentada à Banca Examinadora do Programa de Pós-Graduação em Direito, da Faculdade de Direito da Universidade de São Paulo, como exigência parcial para obtenção de título de Mestre em Direito, na área de concentração Direito Internacional e Comparado, sob a orientação da Profa. Cláudia Perrone-Moisés.

Versão corrigida em maio de 2015. A versão original, em formato eletrônico (PDF), encontra-se disponível na CPG da Unidade.

Universidade de São Paulo 
FOLHA DE APROVAÇÃO

Talitha Viegas Borges

\section{DIREITO À VERDADE E JUSTIÇA DE TRANSIÇÃO: A COMISSÃO DE ACOLHIMENTO, VERDADE E RECONCILIAÇÃO DE TIMOR-LESTE (2002-2005)}

Aprovada em:

\section{Banca Examinadora}

Professora Associada Cláudia Perrone-Moisés

Instituição: Universidade de São Paulo-USP

Assinatura:

Professor(a):

Instituição:

Assinatura:

Professor(a):

Instituição:

Assinatura: 
À minha família, que sempre me deu todo apoio necessário para que pudesse trilhar os caminhos escolhidos. Aos queridos amigos, sem os quais seria impossível apreender o sentido da vida. Aos professores Cláudia Perrone-Moisés, Guilherme de Assis e Celso Lafer, por suas valiosas contribuições a este trabalho. Ao Professor Gustavo Badaró pelo importante papel que teve em minha formação acadêmica. Também ao Professor Dionísio Babo Soares, da Universidade Nacional de Timor-Leste, pelas incursões na história e na cultura de Timor-Leste. Aos queridos amigo Luís Costa e Álvaro Vasconcelos pela amabilidade e generosidade em compartilhar seus conhecimentos. 
BORGES, Talitha Viegas. Direito à verdade e justiça de transição:

a Comissão de Acolhimento, Verdade e Reconciliação de Timor-Leste (2002-2005). 173f. Dissertação (Mestrado) - Faculdade de Direito, Universidade de São Paulo, São Paulo, 2015.

\section{RESUMO}

O trabalho a seguir se propõe a analisar o fundamento teórico do direito à verdade, sua origem histórica e implicações. Para tanto parte da ideia arendtiana de que a verdade factual muitas vezes está em oposição à política. Assim, a mentira e o segredo são instrumentos eficazes para manutenção e sobrevivência do autoritarismo estatal. Portanto, estabelecer a verdade se torna elemento essencial de um estado democrático de direito. $\mathrm{O}$ direito à verdade, nesse sentido é reconhecido como um direito de toda a coletividade e se relaciona à discussão sobre o acesso à informação e a responsabilização de agentes do estado. Existe ainda uma segunda faceta do direito à verdade, que se encontra na origem da construção do conceito e consiste no direito individual em saber sobre as circunstâncias do desaparecimento de pessoas. Além do reconhecimento do direito à verdade, outro problema central dos direitos humanos - e que não pode ser preterido - é a sua efetivação. Com efeito, a enunciação de direitos, por si só, não basta. A partir dessa perspectiva, cumpre observar como o direito à verdade pode ser implementado. Dentre os diversos mecanismos disponíveis, as comissões da verdade chamam especial atenção. Nesse sentido, a Comissão de Acolhimento Verdade e Reconciliação (CAVR) de Timor-Leste representa um marco paradigmático para o direito à verdade. Para compreender o funcionamento e os resultados da comissão é necessário considerar as características gerais de uma comissão da verdade, bem como o contexto social e cultural de Timor-Leste. As comissões da verdade, como meios alternativos de solução de conflitos inserem-se em um contexto de justiça restaurativa, cujo objetivo primordial é o encerramento do ciclo de violência. Em razão do poder reconciliador que possuem, inúmeras comissões instalaramse ao redor do globo, com a onda de democratizações, sobretudo a partir dos anos 90 . Embora seja possível identificar alguns elementos comuns às comissões da verdade, cada um delas conta com peculiaridades próprias. Com efeito, a diversidade de contextos nos quais se desenvolvem os mecanismos de justiça de transição, se traduzem também na diversidade do trabalho de tais instituições. Portanto, para que se compreendam os 
trabalhos e desafios enfrentados pela CAVR, é preciso apreender o contexto da sociedade timorense. Timor-Leste caracteriza-se por ser uma sociedade segmentada, em que a justiça comunitária ainda é o principal meio de solução de conflitos. Outro importante fator é a tradição da linguagem oral, que valoriza a memória para o estabelecimento de regras sociais e de justiça. A CAVR, ao incorporar esses elementos, logrou êxito na condução da reconciliação no nível das comunidades e contribuiu igualmente para a construção da identidade nacional. A documentação produzida serviu ainda como importante referência para que se trouxessem à luz os abusos cometidos. Nesse sentido, teve uma importante função educativa ao esclarecer as relações estabelecidas entre os indivíduos e o estado durante o regime autoritário. Além disso, as recomendações produzidas pela CAVR revelam-se ainda atuais, servindo como referência para o desenvolvimento de instituições e políticas nacionais em Timor-Leste.

Palavras Chave: direito à verdade, comissões da verdade, direitos humanos, Timor-Leste, justiça de transição. 
BORGES, Talitha Viegas. Right to Truth and Transitional Justice: Commission for Reception, Truth and Reconciliation of Timor-Leste (2002-2005). 173. Dissertation (Master) - Faculty of Law, University of São Paulo, São Paulo, 2015.

\begin{abstract}
The following study analyzes the theoretical basis of the right to truth, its historical origin and implications. It's starting point is Hannah Arendt's idea that factual truth is often in opposition to politics. Thus, the recourse to lies and the secrecy are effective tools for the maintenance and survival of state authoritarianism. Therefore, establishing the truth becomes a crucial element of democratic states based on the rule of law. The right to the truth in this regard is recognized as a right of the whole community and relates to the discussion on access to information and accountability of state agents. There is a second dimension of the right to truth, which lies within the original construction of the concept and translates into the individual right to know about the circumstances of the disappearance of persons. In addition to the recognition of the right to truth, another central issue of human rights - and that can not disregarded is its effectiveness. The sole announcement of the recognition of rights is not enough. From this perspective, the way in which the right to truth can be implemented should be noted. Among the various available mechanisms, truth commissions draw special attention. Accordingly, the Commission for Reception Truth and Reconciliation (CAVR) in TimorLeste offers a paradigmatic framework for the right to truth. In order to understand how it operated and the outputs of the commission, it is necessary to consider the general characteristics of a truth commissions, as well as the social and cultural context of TimorLeste. As alternative means of dispute resolution, truth commissions fall into the broader context of restorative justice, for which the primary goal is the end of the cycle of violence . Because of the reconciling power they have, many commissions have been set up around the globe, especially after the wave of democratizations in the 90s. Although it is possible to identify some common elements, each truth commission has its own peculiarities. The diversity of contexts in which transitional justice mechanisms develop, implicate on the diversity of the work of such institutions. Therefore, in order to understand the work and challenges faced by the CAVR, it is necessary to understand the context of East Timorese society. Timor-Leste is a segmented society, where community justice is still the primary
\end{abstract}


means of conflict resolution. Another important factor is the tradition of oral language, which values the memory in order to establish of social rules and justice. By incorporating such elements, the CAVR was successful in driving the reconciliation process at the community level and at the same time contributed to the construction of national identity. The documents the CAVR produced also served as an important reference in order to shred light into the human rights violations. In this sense, it had an important educational role by clarifying the relations between individuals and the state during the authoritarian regime. In addition, the recommendations produced by the CAVR turn out to be still accurate, acting as a reference for the development of national institutions and policies in TimorLeste.

Keywords: right to the truth, truth commissions, human rights, Timor-Leste, transitional justice. 


\section{Lista de Abreviaturas}

AG - Assembleia Geral da ONU

CAVR - Comissão de Acolhimento, Verdade e Reconciliação

$\mathrm{CEDH}$ - Corte Europeia de Direitos Humanos

$\mathrm{CIDH}$ - Corte Interamericana de Direitos Humanos

CIJ - Corte Internacional de Justiça

CNRT - Conselho Nacional de Resistência Timorense

CTF - Comissão para Verdade e Amizade

DUDH - Declaração Universal dos Direitos Humanos

FReTiLIn - Frente Revolucionária para Timor-Leste Independente

OEA - Organização dos Estados Americanos

ONU - Organização das Nações Unidas

TADHP - Tribunal de Africano de Direitos Humanos e dos Povos

TPI - Tribunal Penal Internacional

TRC - Comissão para Verdade e Reconciliação da África do Sul

UNMISET - Missão de Suporte ao Timor-Leste

UNOTIL - Escritório das Nações Unidas

UNMIT - Missão das Nações Unidas para Timor-Leste 


\section{SUMÁRIO}

INTRODUÇÃO

1 DELIMITAÇÕES ACERCA DA VERDADE

$\begin{array}{ll}1.1 \text { A busca da verdade } & 14\end{array}$

$\begin{array}{ll}1.2 \text { As diferentes acepções de verdade } & 16\end{array}$

$\begin{array}{ll}1.3 \mathrm{O} \text { desvirtuamento da verdade } & 19\end{array}$

2 A EMERGÊNCIA DO DIREITO À VERDADE 23

2.1 Verdade factual versus verdade jurídica 23

$2.2 \mathrm{O}$ avanço dos direitos humanos e o reconhecimento do direito à verdade $\quad 30$

2.2.1 Direitos humanos em construção: a perspectiva histórica e a luta pelos direitos $\quad 30$

2.2.2 Os novos meios de comunicação e o avanço dos direitos 36 humanos

$2.3 \mathrm{O}$ direito à verdade no contexto da justiça de transição 38

2.3.1 As origens da justiça de transição 38

2.3.2 Elementos da justiça de transição $\quad 42$

2.3.3 Mudanças de regime e a construção democrática

$2.4 \mathrm{O}$ direito à verdade na ordem internacional $\quad 55$

2.4.1 O reconhecimento do direito à verdade $\quad 55$

2.4.2 A exigibilidade do direito à verdade enquanto obrigação estatal $\quad 70$

$\begin{array}{ll}2.5 \text { Direito à verdade e a reordenação do papel da vítima } & 81\end{array}$

2.6 Verdade, memória e a formação de identidades 83

2.7 Direito à verdade e desenvolvimento democrático $\quad 87$

$2.8 \mathrm{O}$ dilema entre o direito à verdade e a razão de estado 91

3 A COMISSÃO DE ACOLHIMENTO, VERDADE E RECONCILIAÇÃO DE TIMOR-LESTE (2002-2005)

3.1 Os antecedentes históricos $\quad 97$

$\begin{array}{lr}3.2 \text { Aspectos sociais e culturais } & 102\end{array}$

3.3 Elementos da justiça de transição em Timor-Leste 110

$\begin{array}{ll}\text { 3.3.1 Os tribunais e a responsabilização criminal } & 112\end{array}$

$\begin{array}{ll}\text { 3.3.2 Dever de reparação } & 117\end{array}$

$\begin{array}{ll}\text { 3.3.3 Reforma institucional } & 126\end{array}$

3.3.4 As comissões da verdade: CAVR e CTF 136

$\begin{array}{ll}\text { 3.4 A CAVR } & 141\end{array}$

$\begin{array}{ll}\text { 3.4.1 Objetivos e resultados da CAVR } & 146\end{array}$

$\begin{array}{ll}\text { 3.4.2 As contribuições da CAVR } & 158\end{array}$

$\begin{array}{ll}\text { CONCLUSÃO } & 161\end{array}$ 
"Somos a memória que temos e a responsabilidade que assumimos. Sem memória não existimos, sem responsabilidade talvez não mereçamos existir."

José Saramago

\section{INTRODUÇÃO}

O direito à verdade tem recebido uma atenção cada vez maior fruto da expansão que o tema da justiça de transição sofreu, bem como em razão do significativo aumento no número de comissões da verdade que foram criadas nas últimas décadas. Nesse contexto, o direito à verdade vem sendo incorporado como elemento fundamental no combate à impunidade e na reformulação das relações entre cidadãos e estado. Contudo, o tema do direito à verdade não se limita aos contextos transicionais, sendo também um elemento essencial na formulação política e na construção do espaço público. De maneira que a análise do tema pode ser vista a partir de diferentes enfoques.

A partir do enfoque da justiça de transição é possível verificar as origens do direito à verdade, bem como os principais desafios que surgem para sua implementação, em contextos de transformações sociais. Nesse sentido, comissões da verdade oferecem um amplo repertório de análise. A Comissão de Acolhimento, Verdade e Reconciliação de Timor-Leste (CAVR) é considerada, por analistas e estudiosos, como uma das mais bem sucedidas comissões. Mesmo diante das deficiências, o estudo dos trabalhos da CAVR imprime uma importante dimensão prática à análise do direito à verdade.

$\mathrm{O}$ direito à verdade reflete uma construção relativamente recente no campo dos direitos humanos, havendo ainda grandes divergências quanto à sua autonomia e conteúdo. Sob o prisma da historicidade dos direitos humanos, a emergência do direito à verdade se deve inicialmente ao seu reconhecimento no contexto do conflito armado, como reflexo da violação de direitos em razão do desaparecimento de pessoas. Entretanto, a partir da evolução na interpretação de outros tratados de direitos humanos, a verdade passou também a ser reconhecida como um direito individual exigível a qualquer tempo. A atuação das cortes regionais de direitos humanos, bem como a política da ONU para sociedades pós-conflitos, através das operações de paz, foram fundamentais para o desenvolvimento do tema do direito à verdade. 
Comissões da verdade passaram a ser um importante recurso institucional na construção dos estados (statebuilding) que emergiam do pós-conflito. No entanto, a necessidade de criação e fortalecimento dos estados revelou antagonismos entre as concepções ocidentais e não ocidentais de mundo e, sobretudo no que se refere às relações entre estado e indivíduo. Assim, países não ocidentalizados depararam-se com a transposição de conceitos de estado fundados sob a lógica do antropocentrismo, que guiou a história das sociedades ocidentais, sem contudo partilhar do mesmo repertório filosófico e teórico. Nesse sentido, Huntingon fala sobre o choque das civilizações. ${ }^{1}$ Surge, portanto, um descompasso de paradigmas que se reflete nas diferentes percepções acerca dos papeis do estado e das relações de autoridade, assim como o alcance e conteúdo dos direitos humanos.

Essa contraposição de pensamentos pode ser percebida a partir de análises políticas e sociais da constituição dos estados. Entretanto, conforme assinala Heynes essa dicotomia pode ser superada a partir de uma visão de luta pelos direitos. ${ }^{2}$ Os direitos humanos refletem, portanto, a luta dos mais vulneráveis, por aquilo que instintivamente percebem como um direito inerente. Portanto, não se trata propriamente da imposição de uma visão ocidental que se formou, sobretudo a partir da influência Kantiana. Trata-se de um movimento ascendente, que surge a partir do próprio povo, que passa a reivindicar seus direitos. Partindo-se de tal visão, a dicotomia entre visão ocidentalizada de direitos humanos e o mundo não ocidentalizado se dissipa.

No contexto das políticas transicionais da ONU estabeleceu-se a CAVR, com o objetivo de apurar violações de direitos humanos ocorridas durante a ocupação que TimorLeste sofreu pela Indonésia. Timor-Leste, antiga colônia de Portugal, foi invadido em 07 de dezembro de 1975, pelo país vizinho, que permaneceu em seu território até o referendo que votou a favor de sua independência em outubro de 1999. No período que se sucedeu foram estabelecidas operações de paz da ONU para permitir a transição política do novo país independente.

A análise de tais aspectos permite compreender o contexto mais amplo de construção do estado e de justiça de transição no qual se estabeleceu a CAVR. Por outro lado, os elementos da cultura e da sociedade timorense também influenciaram a CAVR

\footnotetext{
${ }^{1}$ HUNTINGTON, Samuel. O choque das civilizações. Rio de Janeiro: Objetiva, 1997.

${ }^{2}$ HEYNES, Cristof. A "Struggle Approach" to Human Rights. In: HEYNES, Cristof; STEFISZYN, Karen (edit). Human Rights, Peace and Justice in Africa: A Reader. Pretoria: Pretoria University Law Press, 2006, p. 15-35. Disponível em: <http://www.pulp.up.ac.za/pdf/2006_05/2006_05.pdf> Acesso em: 09.10.2014.
} 
sobremaneira. Assim, a interação entre os elementos locais e os paradigmas da construção de estado, incorporados a partir das operações de paz do ONU, são essenciais para que se compreenda o trabalho da CAVR, seus sucessos e desafios.

A partir dessas considerações o presente trabalho foi organizado da seguinte maneira: o primeiro capítulo dedica-se à análise do que é verdade, se ela pode ou não ser conhecida e as diferentes acepções de verdade. Trata-se de uma perspectiva jusfilosófica, tendo em vista que o diálogo com a filosofia enriquece a compreensão da realidade. $\mathrm{O}$ segundo capítulo trata da relação entre verdade e direito, analisando assim o reconhecimento histórico do direito à verdade. São igualmente analisadas questões como a verdade e a esfera pública. O terceiro capítulo aborda a implementação do direito à verdade por meio do trabalho da CAVR. Para tanto, é feita uma análise preliminar dos fatos que antecederam a criação da CAVR, bem como do contexto social. O capítulo final traz as conclusões e uma breve síntese do trabalho desenvolvido.

Para fins metodológicos, existem duas indagações de cunho geral ao redor das quais se orientam as discussões do trabalho. A primeira diz respeito à possibilidade de se afirmar a existência de um direito à verdade. Em caso afirmativo, resta a indagação a respeito do conteúdo e alcance desse direito. A amplitude de tais questionamentos leva à necessidade de se realizar um recorte teórico, tomando-se por objeto de análise os trabalhos da CAVR, seus sucessos e suas deficiências. 


\section{DELIMITAÇÕES ACERCA DA VERDADE}

A possibilidade de conhecer a verdade, como identificá-la, e a sua própria existência foram objeto de preocupação da filosofia e de outros campos do saber ao longo da história da humanidade. Compreender o significado do vocábulo verdade é fundamental para analisar o papel que possui no campo dos direitos humanos. Assim, sem esgotar o assunto, faz-se pertinente a discussão sobre o que pode ser considerado verdade e suas diferentes dimensões.

\subsection{A busca da verdade}

Ao se debruçar sobre a verdade diversas indagações podem ser colocadas. Platão colocara a questão de como procurar a verdade. Nesse sentido, a verdade relaciona-se à atribuição, ao nome que se dá às coisas. No diálogo entre Sócrates e Cratylus, discute-se como identificar se determinado nome atribuído a algo está correto. Por um lado, é possível argumentar que um nome é correto, na medida em que assim tenha sido convencionado pela comunidade (nomos). Assim, identificar se um vocábulo corresponde à verdade seria uma questão de construção social. Em sentido diverso, é possível sustentar que um nome está correto na medida em que revela a natureza do objeto descrito e portanto não traduz necessariamente uma convenção social e sim a essência daquilo que é descrito (pyhsis). Por fim, Sócrates, por meio da narrativa de Platão, conclui que é preciso ir além das palavras e identificar o aspecto permanente e imutável da natureza das coisas. ${ }^{3}$

Dessa forma, se um nome atribuído a algo estiver correto, ele será também verdade. Se, porém, o nome atribuído estiver incorreto, então é falso. Portanto, neste viés, verdade está em oposição ao falso. Platão descreve, então, como Sócrates chega à conclusão de que é preciso analisar a essência do objeto nomeado, identificando seu núcleo, aquela característica que lhe é indispensável.

A verdade, portanto, aqui está relacionada à atribuição de significado e correspondência. Nesse sentido, é possível dialogar com Hannah Arendt, para quem a

\footnotetext{
${ }^{3}$ COOPER, John M. (org). Plato Complete works. Indianapolis: Hackett Publishing Company, 1997, p.101.
} 
atribuição de significado às palavras não pode ser objeto de uma terminologia privada. ${ }^{4}$ Com isso quer dizer que, para que possa haver mútua compreensão e um verdadeiro diálogo é necessário reconhecer a importância das distinções. A atribuição de nomes para identificação da verdade depende, portanto, do reconhecimento da natureza inerente à coisa. Ao mesmo tempo em que um objeto ou um fato social deve ser descrito em sua essência, o significado das palavras passa a ser também um fenômeno social, em razão de seu caráter público. O espaço público, segundo Arendt, depende portanto desse elemento comum: a atribuição correta dos significados. Não pode haver debate se os pressupostos dos quais se partem são falsamente atribuídos. Portanto, trata-se de estabelecer uma correspondência entre a descrição e os fatos ou objetos.

Essa indagação inicial acerca do que é ou não verdade, leva em conta a precisão e a linguagem descritiva e portanto pressupõe o seu conhecimento pelo ser humano através as experiências sensoriais e cognitivas. Mas, a verdade existe independentemente de estar ao alcance do conhecimento humano. Assim, é possível afirmar que a composição de um átomo, sempre foi a mesma, porém só foi desvendada pelo ser humano a partir do avanço da ciência. O fato, portanto, é o mesmo e permanece imutável, mas com o descobrimento pelo ser humano, traz consigo uma série de consequências.

O mesmo ocorre no espaço público. É possível afirmar que a verdade inacessível, aquela verdade que não é comunicada, que é ocultada ou mascarada influencia também a dinâmica do espaço público. Portanto, ao lado da preocupação de reconhecimento da verdade - ou seja, distingui-la em meio aos erros terminológicos - subsiste também uma preocupação no que se refere à comunicação da verdade. A verdade ao ser veiculada carrega consigo uma série de consequências e enseja o debate, daí porque a construção política sempre anda às voltas com a discussão em torno do reconhecimento de verdades.

Trazer os fatos à público depende, portanto, do estabelecimento de pontes de comunicação, que permitam descortinar os fatos mantidos em sigilo ou travestidos de falsidades. Nesse sentido, a literatura, o cinema e a arte em geral possuem esse poder de revelação dos fatos, através de uma linguagem própria que as caracteriza. ${ }^{5}$ Não por acaso, a censura à produção cultural é uma das marcas que caracterizam os sistemas autoritários,

\footnotetext{
${ }^{4}$ ARENDT, Hannah. Entre o passado e o futuro. São Paulo: Perspectiva, $11^{\mathrm{a}}$ ed. 2011, p. 132-133.

${ }^{5}$ Possíveis exemplos são obra $O$ ano em que Pigafeta completou a circum-navegação, que retrata o período da ocupação indonésia de Luis Cardoso (Porto: Porto Editora, 2013) e o filme Balibo, que narra a morte de jornalistas australianos pelas tropas indonésias, quando da invasão de Timor-Leste (CONNOLY, Robert (dir.) Australia. 2009).
} 
uma vez que esse poder de comunicação pode mostrar-se contrário à manutenção do poder. Por isso, os movimentos culturais são um importante motor de contestação em contextos marcados pela ocultação de informações.

As manifestações artísticas enquanto meios de comunicação dos fatos estabelecem um elo entre o passado e as futuras gerações, ao narrarem os acontecimentos a partir de uma linguagem simbólica. Em razão disso, os bens culturais devem ser protegidos enquanto elementos da formação de um povo, mas também enquanto elementos que informam o espaço público. São, portanto, acessíveis a um maior número de pessoas. $\mathrm{O}$ papel da arte nesse sentido complementa o papel exercido pela mídia, através de jornais, televisão e mais recentemente a internet.

Ao lado desses mecanismos de comunicação, a revelação da verdade, pode também ser realizada por documentos oficiais e através do trabalho investigativo, cuja característica narrativa se sobressai. Por isso relatórios de estados ou mesmo relatórios não oficiais, como por exemplo aqueles produzidos por entidades da sociedade civil, também tem a importante função de levar a verdade a público. Nesse sentido, as comissões da verdade, através de investigação, produzem um material de suma importância ao revelar acontecimentos passados, sobretudo no que se refere a violações de direitos humanos. São instrumentos por meio dos quais as verdades factuais vêm à tona, além de outras funções que normalmente lhe são atribuídas, como a reconciliação.

Os documentos produzidos por uma comissão da verdade possibilitam, portanto, o conhecimento e o reconhecimento da verdade. Devem refletir com adequação e correspondência os acontecimentos e as violações de direitos humanos ocorridas. Assim, trazem os fatos à luz e ao buscar o núcleo dos acontecimentos, atribui-lhes o significado verdadeiro.

A questão da correlação entre a narração e os fatos é, portanto, essencial para o estabelecimento da verdade. Existe um núcleo duro invariável a orientar essa verdade. A maneira como essa verdade será comunicada ou investigada, entretanto, pode ter diferentes formas.

\subsection{As diferentes acepções da verdade}

Podem ser identificados diversos tipos de verdade como: verdade revelada, verdade científica, verdade filosófica, verdade moral, verdade racional, verdade factual e 
verdade jurídica. A verdade revelada é fruto da conexão entre o divino e o sobrenatural. Assim, não é o ser humano que estabelece o que é ou não verdade. O ser humano, tal como um oráculo, é apenas um instrumento para comunicação da verdade. Nesse sentido, não cabe ao homem questionar essa verdade, pois ela é estabelecida pelo divino. Essas verdades são, portanto, os dogmas, que funcionam como verdades irrefutáveis a orientar as ações humanas.

A verdade revelada preponderou sobre o pensamento ocidental até o momento em que passou a ser questionada, dando lugar à primazia da verdade racional, através de um processo de desmistificação. De maneira que a verdade racional está enraizada na ciência moderna, na dúvida cartesiana. A partir de então, a confiança na capacidade que os sentidos têm de revelar, foi perdida. Assim, a verdade racional passou a assumir uma posição de superioridade na construção do mundo ocidental, sobretudo após a ruptura entre igreja e estado.

Mas, é preciso reconhecer também que esse processo de desmistificação, que caracteriza o pensamento ocidental, não reverberou de forma uniforme por toda parte. Assim, a verdade revelada, enquanto proveniente do divino ainda é marcante em algumas sociedades que permaneceram alheias a esse processo de contestação e de valorização da racionalidade humana. Mesmo em sociedades marcadas por esse processo de desmistificação houve uma permanência de elementos divinos em torno da verdade. Por isso, é preciso ter em conta o misticismo que ainda permeia a esfera política e que influencia os debates e espaços públicos, onde coexistem verdades racionais e verdades reveladas.

A verdade racional é aquela produzida pela mente humana, tanto no campo filosófico quanto no campo das ciências. A verdade científica pode ser considerada como aquela verdade matemática, própria das ciências exatas e naturais. A preposição de que dois mais dois são quatro pode ser considerada uma verdade científica, porque não comporta uma margem para alterações ou questionamentos, tratando-se de um dado objetivo. A verdade científica acomoda questionamentos e antíteses, uma vez que a racionalidade é inerente a todo ser humano. Não se trata mais de uma verdade revelada, pelo divino. A verdade científica é a verdade criada a partir da atividade humana de pensamento.

A verdade racional abrange não apenas a verdade matemática, mas também a verdade filosófica. Para Hannah Arendt, a verdade filosófica não é política por natureza. 
Diz respeito ao homem enquanto indivíduo singular. Assim, é uma espécie de verdade racional, pois também é produzida pela mente humana, mas opera a partir de uma linguagem diferenciada em relação à matemática.

A verdade factual, por sua vez, diz respeito a fatos e acontecimentos. São muito mais frágeis que proposições axiológicas, que podem ser redescobertas, desconstruídas e reconstruídas. A verdade factual, uma vez apagada da memória histórica, jamais pode reemergir, porque não deixa vestígios e não pode ser reproduzida pela mente humana, tal como as proposições matemáticas ou filosóficas. Por isso, verdades factuais não podem ser exemplificadas. São também extremamente suscetíveis ao poder, justamente pela impossibilidade de serem recriadas. De acordo com Hannah Arendt:

\begin{abstract}
A verdade factual, ao contrário, relaciona-se sempre com outras pessoas: ela diz respeito a eventos e circunstâncias nas quais muitos são envolvidos; é estabelecida por testemunhas e depende de comprovação: existe apenas na medida em que se fala sobre ela, mesmo quando ocorre no domínio da intimidade. É política por natureza. ${ }^{6}$
\end{abstract}

Dessa forma, a verdade factual está sempre em colisão com o poder, que - não obstante - não pode substituí-la, mas apenas destruí-la. Nesse sentido, a verdade factual é imutável. Para Hannah Arendt não é possível mudar o fato de que Alemanha invadiu a Bélgica, em 1914. Esse mesmo fato pode ser contado de diversas maneiras, mas existe um núcleo duro. Assim, por mais que existam diversas versões do ponto de vista histórico nada mudará o fato de que foi a Alemanha que invadiu a Bélgica, e não o contrário.

A distinção entre as diversas espécies de verdade é o ponto de partida para as discussões em torno do direito à verdade. A verdade factual é a essência que caracteriza esse direito quando se postula o seu reconhecimento na qualidade de direito humano fundamental. A argumentação em torno do reconhecimento e da efetivação do direito à verdade gira em torno do acesso ao conhecimento e reconhecimento dos fatos e violações de direitos humanos.

O caráter fundamental da verdade factual revela-se em um duplo sentido: no direito individual de cada ser humano em ter acesso ao conhecimento e no papel que a verdade possui na construção do espaço público, que é frequentemente esquecido ou subestimado. Sobretudo, a compreensão do papel da verdade na política e também no

\footnotetext{
${ }^{6}$ ARENDT, Hannah. Entre o passado e o futuro. São Paulo: Perspectiva, 11 a ed, 2011, p. 295.
} 
direito passam pela diferenciação entre a verdade factual e outras acepções de verdade, como a verdade cientifica e a verdade filosófica. Mas, é a verdade factual e sua rede de causalidades que interessa ao campo dos direitos humanos.

\subsection{O desvirtuamento da verdade}

Quando se adentra o universo dos estudos sobre a verdade há que se considerar uma objeção frequente. Argumenta-se que a verdade é relativa e, portanto depende de um dado ponto de vista. Segundo essa linha de pensamento, a verdade é subjetiva, na medida em que retrata as percepções humanas e todas as variações que delas advém. Considerando que a verdade varia de acordo com o sujeito ela poderia ser transformada, como se fosse um fluído capaz de moldar-se ao corpo que lhe contém e que pode se adequar às necessidades do narrador.

Embora opinião e verdade factual pertençam ao mesmo domínio, não devem ser confundidas, conforme sustenta Hannah Arendt. ${ }^{7}$ A verdade factual opera no campo dos acontecimentos. As opiniões são apropriações humanas dessas circunstâncias. Nesse sentido, pode-se dizer que a opinião é reflexo da conjunção entre fatos e percepções humanas. A opinião tem um caráter dinâmico porque se sujeita a traço discursivo que lhe é próprio, percorre o caminho da persuasão.

A verdade factual percorre um caminho diverso pois não se sujeita ao consentimento ou ao discurso do convencimento. A verdade factual, nesse sentido, impõese de maneira despótica. É o que é. A verdade factual pode ser estabelecida através de documentos, testemunhos, obras de arte e outros espécies de registro. Nesse sentido, o registro desenvolvido pelas comissões da verdade, permitem que a verdade factual seja trazida à luz, possibilitando assim o debate público e a partir daí a formação de opinião.

Portanto, há uma linha divisória que marca a distinção entre verdade factual e opinião. Essa diferenciação é fundamental para a vita activa. A verdade servirá de base comum para o debate público. A opinião é uma forma de interpretação dos fatos e por isso é naturalmente dinâmica. Fatos são estáticos, mas podem ser interpretados e reinterpretados. O revisionismo histórico, por exemplo, incorpora essa dinâmica das novas

\footnotetext{
${ }^{7}$ ARENDT, Hannah. Entre o passado e o futuro. São Paulo: Perspectiva, $11^{\text {a }}$ ed. 2011, p. 295-303.
} 
interpretações, oferecendo novos olhares sob a historiografia, a maneira como é escrita a história.

Por isso, verdade factual e opinião não se tratam de termos antagônicos. A verdade factual informa a opinião. Muitas vezes, no entanto, uma opinião trasveste-se de verdade. Por isso, alerta Hannah Arendt, há que se atentar para opiniões que na realidade se tratam de puras mentiras mascaradas. Portanto, o termo que se opõe a verdade factual não é opinião e sim a mentira.

A opinião reflete determinada representação dos fatos, não os substitui, apenas oferece um campo interpretativo. A respeito da representação aponta Paul Ricoeur:

Em oposição à ideia unilateral, indiferenciada e maciça de mentalidade, a ideia de representação expressa melhor a plurivocidade, diferenciação e temporalização múltipla dos fenômenos sociais. Nesse aspecto, o campo político oferece um terreno favorável a uma exploração regrada de fenômenos relativos à categoria de representação. Sob esse nome, ou o de opinião, ou até de ideologia, esses fenômenos prestam-se a operações de denominação e de definição, às vezes acessíveis à quantificação pelo método das cotas." (grifo nosso)

Portanto, opinião é um fenômeno representativo, diferenciando-se dos fatos. A representação histórica aspira refletir a verdade de maneira fidedigna. Entretanto, a representação não se refere apenas à verdade factual, mas resulta de um discurso histórico interpretativo. Por isso, a representação, embora tenha a pretensão de retratar o passado adequadamente, sujeita-se a interpretação. Essa interpretação se dá em três níveis, que correspondem às fases do discurso histórico, segundo Paul Ricouer. Identifica assim as três fases: a fase documental, a fase de explicação/compreensão e a fase da representação literária do passado, também chamada de reconstrução. Aponta que: “a interpretação é um traço da investigação da verdade em história que perpassa os três níveis: a interpretação é um componente da própria intenção de verdade de todas as operações historiográficas"9

Assim, é possível descortinar a relação existente entre verdade factual e a formação de ideologias e opiniões, a fim de compreender as influências que exercem uns sobre os outros. Identificar em que medida as representações encontram correspondência em relação à verdade talvez seja uma das tarefas mais árduas, na construção do espaço e do debate público. Justamente em razão do discurso histórico estar sujeito à interpretação é

\footnotetext{
${ }^{8}$ RICOEUR, Paul. A memória, a história, o esquecimento. Campinas: Editora Unicamp, 2007, p. 239.

${ }^{9}$ Idem, p. 196.
} 
que ocorrem os abusos e a manipulação da memória. A própria narrativa tem uma função seletiva, os fatos revelados são escolhidos orientados por uma memória a ser ensinada. Daí surge a necessidade de se criarem mecanismos para verificação da verdade e da correspondência entre as representações e os acontecimentos.

A compreensão do fenômeno da representação, bem como dos abusos da memória, torna mais clara a compreensão do papel da verdade na construção do espaço público. Para dialogar com Hannah Arendt, os fatos e eventos "constituem a verdadeira textura do domínio político". ${ }^{10}$ É pela essencialidade dos fatos no debate público e no espaço político que as comissões da verdade adquirem um papel informador fundamental.

Mas, tendo em conta todas as possíveis formas de abuso da memória, há que se atentar para que as comissões da verdade não sejam transformadas em espaços de formação de ideologias revanchistas ou de perseguições políticas. Ao contrário, uma comissão da verdade deve se prestar ao esclarecimento dos fatos. Para dialogar mais uma vez com Paul Ricouer: "a manipulação da memória em favor da ideologia provoca efeitos sobre a compreensão de mundo levando a uma distorção da realidade, à legitimação do sistema de poder e à integração do mundo". " Por isso, uma comissão da verdade não deve ser um instrumento de manipulação ideológica e sim um meio para revelação dos fatos e, sobretudo, um espaço para participação das vítimas e para o debate público.

O desvirtuamento da verdade pode verificar-se das mais variadas formas. A mentira trasvestida de opinião é apenas uma delas. Mas, é possível identificar ainda outras formas de desvirtuamento da verdade, tais como o erro, a ignorância e a ilusão. O erro e a ignorância nada mais são do que uma falha não intencional, estão em oposição à verdade racional e encontram-se no campo da ciência. A ilusão e a opinião, também estão em oposição à verdade racional, porém no campo filosófico.

Por sua vez, a falsidade e a mentira estão em contraposição à verdade factual, porque se tratam de desvios deliberados dos fatos, ${ }^{12}$ contendo o elemento da intencionalidade. Uma afirmação é falsa, na medida em que atribua algum significado incompatível com sua natureza. Uma afirmação falsa - assim como uma mentira

\footnotetext{
${ }^{10}$ ARENDT, Hannah. Entre o passado e o futuro. São Paulo: Perspectiva, $11^{\mathrm{a}}$ ed. 2011, p. 287.

${ }^{11}$ RICOEUR, Paul. A memória, a história, o esquecimento. Campinas: Editora Unicamp, 2007, p. 95.

12 ARENDT, Hannah. Op.cit. p. 288.
} 
organizada - segundo Hannah Arendt, diz respeito a verdades fatuais. Há portanto, uma linha divisória entre o erro - que é o pseudos involuntário - e a mentira. ${ }^{13}$

Essa diferenciação pode ser extremamente difícil na prática e muitas vezes até mesmo impossível. Desvendar a intencionalidade do agente sempre foi uma das questões mais complexas da humanidade. Daí a grande dificuldade em se atribuir responsabilidades pela disseminação de afirmações falsas.

Ao lado da mentira e da falsidade, que desvirtuam a verdade de forma deliberada, o segredo é também uma preocupação central nos estudos sobre o direito à verdade. Entretanto, é preciso esclarecer que o segredo não é propriamente uma forma de desvirtuamento da verdade. Enquanto a mentira reflete a realidade de maneira falsa, em oposição à verdade, o segredo consiste na ocultação intencional de informação. Impõe uma barreira ao conhecimento.

Sissela Bok descreve o segredo como uma forma de separação entre aqueles que possuem o acesso à informação e aqueles que estão fora desse círculo restrito. ${ }^{14}$ Portanto, verdade e segredo não necessariamente estão em oposição. Apesar do segredo não se caracterizar propriamente como um desvirtuamento da verdade, o estudo do direito à verdade também engendra a ideia de trazer os fatos a público. Assim, para o estudo do direito à verdade, a revelação dos fatos é um tema tão importante quanto a correspondência entre as afirmações e a verdade factual. ${ }^{15}$

O desvirtuamento da verdade - que pode tomar as formas mais variadas possíveis (opinião, mentira, falsidade) - ou mesmo sua ocultação são elementos constantemente presentes no domínio político. Em razão disso, torna-se essencial assegurar meios de preservação e proteção da verdade contra os assédios do poder. A importância inerente da verdade factual se depreende em razão de sua essencialidade para o debate público, para a tomada de decisão dos cidadãos e para a responsabilização dos agentes envolvidos.

${ }^{13}$ ARENDT, Hannah. Entre o passado e o futuro. São Paulo: Perspectiva, 11 a ed. 2011.

${ }^{14}$ BOK, Sissela. Secrets - On the Ethics of Concealment and Revelation. New York: Vintage Books, 1989.

${ }^{15} \mathrm{~A}$ relação entre o segredo e a razão de estado será abordada de maneira mais aprofundada no capítulo 2.8 . 


\section{A EMERGÊNCIA DO DIREITO À VERDADE}

É preciso compreender a verdade como elemento informador e ao mesmo tempo integrado no estudo do direito. Primeiramente é necessário analisar a distinção entre verdade factual e verdade jurídica a fim de que se possa posteriormente estabelecer como o direito à verdade surgiu e como ele ainda procura se afirmar diante das violações de direitos humanos. Ademais, é imprescindível compreender a quem esse direito é dirigido. Assim, fala-se em uma dimensão individual e uma dimensão coletiva do direito à verdade.

\subsection{Verdade factual versus verdade jurídica}

Foram pontuadas, no presente estudo, algumas distinções necessárias entre as diferentes acepções de verdade e também entre as várias formas possíveis de desvirtuamento da verdade. Sob a perspectiva do direito à verdade, é preciso ainda estabelecer outra distinção fundamental: entre verdade factual e verdade jurídica, que não se confundem. A verdade jurídica se materializa na coisa julgada. É a estabilização das relações, ou em outras palavras, é a domesticação do tempo. O estado ao atuar como julgador realiza um recorte da realidade, limitando aquilo que será julgado e as provas que serão analisadas. Assim, a verdade jurídica nada mais é do que o reflexo desse recorte que se faz, tendo em vista os limites impostos pelas normas de natureza processual e material. ${ }^{16}$

Por vezes, a verdade jurídica pode corresponder à verdade factual. Em tais circunstâncias, normalmente há uma percepção de que o direito e os ideais de justiça convergem. Não raro, porém, a verdade jurídica anda em descompasso com a verdade factual. Em tais casos há uma quebra na confiança das instituições estatais e na expectativa

\footnotetext{
${ }^{16}$ Daniel Simião, em seu trabalho sobre sensibilidades jurídicas, retrata o processo judicial como um artefato cultural. Assim, a linguagem normativa é transposta para o fato. Conforme pontua, a tradição ocidental, para traduzir o fato, utiliza-se de conceitos de julgamento e de provas. Essa é apenas uma das possíveis sensibilidades jurídicas. Partindo-se da perspectiva das sensibilidades jurídicas de que fala Simião é possível compreender que o processo judicial, ao estabelecer a verdade jurídica, através da coisa julgada, é na verdade o reflexo de uma visão de mundo limitada pelas regras processuais. Daí, porque nem sempre a verdade jurídica corresponde à verdade factual.

SIMIÃO, Daniel Schroeter. Sensibilidade jurídica e diversidade cultural: dilemas timorenses em perspectiva comparada. In: SILVA, Kelly; SOUZA, Lúcio (orgs.). Ita maunalin: o livro do irmão mais novo. Lisboa: Edições Colibri, 2011.
} 
que se tem sobre a atuação das instâncias judiciais. Essa quebra de expectativa pode levar a uma desconfiança em relação às instituições judiciais, elevando uma espécie de barreira entre o judiciário e a sociedade. Há uma percepção de que as instituições jurídicas e estatais estão descoladas da realidade, porque não conseguem em determinados casos apreender toda a miríade de elementos envolvidos em determinada situação, de maneira a orientar o processo e o julgamento.

Trata-se de uma visão que deve ser analisada cuidadosamente nos estudos acerca da teoria da justiça. Mas, o principal elemento que se quer extrair dessa linha de argumentação é a compreensão de que verdade jurídica e verdade factual nem sempre são correspondentes. Essa diferenciação é essencial para a compreensão do desenvolvimento e reconhecimento do direito à verdade.

A verdade jurídica se ocupa em reconhecer a existência ou não de certas relações jurídicas. Em um estado de direito ela é limitada por regras de direito material e pelo direito processual. Em estados marcados pelo autoritarismo a verdade jurídica pode tomar as mais variadas formas, sem que se atente a essas limitações, já que não necessariamente são observadas as garantias individuais. Ainda sim, será apenas uma verdade jurídica e não necessariamente irá coincidir com a verdade factual.

A verdade factual, diz respeito aos acontecimentos. Nesse sentido, não cabe ao direito impor limites para dizer o que pode ou não ser verdade. Não há contingência limitadora dos acontecimentos, como a própria história tem insistentemente demonstrado. Portanto, o direito não pode impor limites aos fatos já ocorridos e nem é capaz de modificá-los ou apagá-los. Nesse sentido, a verdade factual se afasta da verdade jurídica, porque esta comporta um universo de fatos limitados pelas regras de julgamento, ao realizar um recorte para fins de análise do caso concreto.

Dessa forma, o direito por si não é capaz de impor um corte metodológico à verdade factual, da mesma forma que faz com a verdade jurídica. Pode apenas limitar os instrumentos e a forma como a verdade factual será comunicada, por exemplo através de leis de imprensa ou leis que imponham sigilo a determinados documentos. É preciso, portanto, reconhecer que os instrumentos jurídicos e o direito podem ser utilizados para impor limitações à revelação da verdade factual, embora não seja capaz sozinho de modificá-la. Enquanto a verdade jurídica é condicionada pelo direito, a verdade factual opera no plano dos acontecimentos. 
Para Hannah Arendt, a verdade factual padece de fragilidade, pois no momento em que ela desaparece, não há mais como recuperá-la. Diferentemente da verdade racional, que pode ser redescoberta através do próprio homem, a verdade factual uma vez destruída não pode ser substituída por uma nova verdade factual: "a verdade é que isto [se livrar dos fatos] não pode ser feito nem pela teoria nem pela manipulação da opinião - como se um fato pudesse ser removido do mundo simplesmente porque gente bastante acredita na sua não-existência. Isto só pode ser feito através de radical destruição". ${ }^{17}$

Sob esse prisma, o direito pode servir como instrumento de manipulação da verdade ou de restrição a seu acesso. ${ }^{18}$ Portanto, pode impor barreiras de comunicação, impedindo o acesso da população à verdade factual, mas a completa destruição da verdade exige um sistema de dominação total, que depende não apenas de instrumentos jurídicos. A dominação total de que fala Hannah Arendt emerge no seio dos sistemas totalitários.

Mas, a restrição de acesso à verdade factual, através do sigilo de documentos e da censura de manifestações artísticas e culturais, por exemplo, ocorre também em regimes autoritários ou mesmo democráticos. Nesse sentido, o direito à verdade não é uma preocupação que se restringe ao contexto totalitário, mas permeia toda a formulação do poder político.

Conforme apontado, a verdade a que se refere aqui é a verdade relativa aos fatos, que não se confunde com a verdade jurídica. Ao debruçar-se sobre essa distinção, inevitavelmente emerge também o debate em torno da relação entre verdade e punição, uma vez que esta é reflexo da verdade jurídica, estabelecida no curso do processo. É necessário, portanto, realizar um corte no sentido de que não necessariamente a ausência de punição condicione o reconhecimento da verdade factual. Mesmo diante da impunidade, um direito ao conhecimento da verdade factual deve subsistir. Sob esse prisma, as comissões da verdade permitem o esclarecimento dos fatos e produção da memória - que nem sempre tem seu lugar assegurado por meios judiciais.

O processo judicial é conduzido tendo-se em perspectiva regras como leis de anistia e prescrição. Especialmente em contextos de justiça de transição, essas normas representam sérios obstáculos à responsabilização dos agentes. O que se questiona é o alcance e legitimidade dessas normas.

${ }^{17}$ ARENDT, Hannah. Crises da República. São Paulo: Perspectiva, 2a ed. 2004, p. 21.

${ }^{18}$ A relação entre a verdade e a razão de estado não é uma preocupação unicamente em estados autoritários, uma vez que até mesmo estados democráticos, procuram assegurar o sigilo de certas informações sensíveis. Para uma análise mais aprofundada entre segredo e razão de estado, verificar o capitulo 2.8. 
Quando se adentra a esfera de crimes contra a humanidade os institutos da anistia e prescrição passam por uma série de indagações, devido à natureza das violações. Por atingirem toda a humanidade em seu núcleo essencial, os crimes contra a humanidade não deveriam estar sujeitos a normas que impõem limites temporais à responsabilização (prescrição) ou que extinguem a punibilidade como consequência da política criminal (anistia). Com efeito, a defesa da imprescritibilidade e da não sujeição dos crimes contra a humanidade às leis de anistia têm frequentemente gerado uma polarização de opiniões.

A esse respeito é importante retomar as origens das garantias processuais penais. Uma análise histórica revela que as garantias processuais penais surgiram como um freio ao poder arbitrário estatal. Nasceram, portanto, como garantia do indivíduo contra abusos do poder. A anistia e prescrição, por sua vez, caracterizam-se como instrumentos de política criminal, ou seja, refletem as escolhas políticas que garantem uma maior harmonização social. Ao retomar as origens de tais institutos, cumpre indagar se a finalidade a que se prestam, também se verifica nos casos de crimes contra a humanidade.

Alguns casos emblemáticos de crimes contra a humanidade, como o genocídio durante o regime nazista, o genocídio de Ruanda e do Camboja levam à inevitável conclusão de que tais crimes foram cometidos num contexto sistemático de utilização do aparelho estatal. Nesse sentido, fala-se em uma macrocriminaldade política. De acordo com Kai Ambos ela pode ser entendida em dois sentidos. ${ }^{19}$ Em sentido estrito refere-se à criminalidade que ocorre em condições políticas de exceção e em que o estado desempenha um papel ativo. Em sentido amplo, a macrocriminalidade política inclui hoje também os crimes internacionais perpetrados por agentes não estatais como o terrorismo, por exemplo. Assim, a natureza distintiva dos crimes de macrocriminalidade política, em sentido estrito, no qual os agentes estatais exercem um papel ativo, exige também a ressignificação da própria estrutura do direito penal e do processo penal.

As garantias processuais e os institutos da política criminal, como a anistia e a prescrição, foram concebidos justamente como forma de garantia do indivíduo frente aos abusos do poder estatal e enquanto políticas criminais de harmonização social. Mas, nos crimes contra a humanidade cometidos no uso do poder estatal, essas garantias e instrumentos mostram-se inadequadas, porque se encontram em conflito com suas próprias finalidades. Ora, uma garantia erigida para fazer frente ao uso arbitrário do poder não

19 AMBOS, Kai. A parte geral do direito penal internacional: Bases para uma elaboração dogmática. São Paulo: Editora Revista dos Tribunais, 2008, p. 54-59. 
pode ser invocada para garantir a impunidade por esses mesmos abusos. A mesma observação se aplica aos institutos da anistia e prescrição, que perdem sua razão de ser frente à macrocriminalidade do estado. Há, portanto, um descolamento entre as finalidades das garantias processuais penais, bem como dos institutos como a anistia e a prescrição, quando se analisa o contexto em que esses crimes foram praticados.

Argumenta-se, por outro lado, que as garantias individuais devem ser aplicadas, independentemente do caso concreto, pois a relativização traz consigo o risco de criar-se sempre uma exceção à regra. Mas, conforme apontado, tal argumento deve ser rechaçado já que a própria natureza dos crimes contra a humanidade difere de qualquer outro crime, tal como concebido pelo direito penal em sua formulação clássica.

Mas, o debate em torno dessa questão é mais profundo do que podem comportar essas breves considerações. O que se quer destacar aqui é a relação entre verdade factual e as leis de anistia ou de prescrição, enquanto limitadoras da pena e da atividade jurisdicional. Nas palavras de Cláudia Perrone-Moisés: "a questão da impunidade, como consequência da edição de leis de anistia, insere-se na discussão acerca da busca da verdade e da justiça como forma de proteção dos direitos humanos". ${ }^{20}$

Tendo em conta os fins da atividade jurisdicional, é de se indagar se a verdade factual pode também ser afirmada através de demandas jurisdicionais, mesmo diante de leis de anistia e da prescrição. Para isso, é necessário ter em conta as funções do procedimento judicial. $\mathrm{O}$ direito de acesso às instâncias judiciais, o direito de pedir, é direito humano fundamental reconhecido pela ordem internacional. Disso resulta ser perfeitamente admissível o reconhecimento do direito à verdade através de demandas judiciais. Sustenta-se aqui, que mesmo diante de leis de anistia e de regras de prescrição, o direito ao conhecimento dos fatos - consubstanciado na verdade factual - permanece intocado pelas normas de extinção de punibilidade. É preciso estar atento para fato de que as instâncias jurisdicionais não se prestam somente à atividade de punição ligada à esfera do direito penal. A atividade jurisdicional diz respeito à amplitude de relações sociais. Daí porque também se mostra possível o pedido de reconhecimento de determinado fato, ou de determinada relação jurídica, independentemente dos pressupostos necessários à responsabilização penal.

${ }^{20}$ PERRONE-MOISÉS, Cláudia. Direito internacional penal. Barueri: Manole, 2012, p. 116. 
A adjudicação em favor do reconhecimento do direito à verdade tomou corpo, sobretudo, no contexto latino-americano de redemocratização. A esse respeito, cumpre mais uma vez retomar os ensinamentos de Cláudia Perrone-Moisés, que pontua:

Os resultados iniciais de julgamentos efetuados pelo Poder Judiciário argentino não forneciam resposta uniforme a essas questões, dado que alguns reconheciam o direito à verdade, enquanto outros o restringiam ou negavam, mas seu papel fundamental para a legitimação das demandas fundadas nesse direito. Além disso, a intervenção judicial construiu um ponto de inflexão que determinou a transcendência pública da questão. ${ }^{21}$

Portanto, a priori não há óbice para o estabelecimento da verdade factual através dos tribunais. Isso porque a atividade de dizer o direito, a que se propõe o juiz, não se limita ao estabelecimento de penas e de responsabilização penal. É muito mais ampla e se presta também ao reconhecimento da amplitude de relações jurídicas, o que inclui o acesso à informação. $\mathrm{O}$ reconhecimento do direito à verdade enquanto direito humano fundamental engendra a ideia do direito de saber, e sua consequente efetivação, inclusive através de demandas judiciais.

Por outro lado, a realidade demonstra que o reconhecimento do direito à verdade através das instâncias jurisdicionais não é uniforme, refletindo as configurações díspares dos sistemas jurídicos internos. Assim, antes de se atestar de maneira categórica a possibilidade de se reconhecer o direito à verdade através de demandas judiciais é necessário levar em conta que internamente trata-se ainda de uma questão que encontra a resistência característica do positivismo jurídico restritivo, que se funda na necessidade de regras explícitas insculpidas na forma de leis e que passa por cima da análise sistêmica de regras e princípios orientadores do direito. A resistência de alguns tribunais em reconhecer o direito à verdade resulta de uma associação entre o positivismo acrítico e a ausência de previsões explícitas em alguns ordenamentos prevendo o direito à verdade.

Esse posicionamento, entretanto, vem aos poucos sendo superado nos ordenamentos que primam pelas regras inerentes ao estado democrático de direito e diante da inevitável constatação de que o direito à verdade já é reconhecido pela ordem internacional. ${ }^{22}$ Esse reconhecimento internacional, através de tribunais, declarações de

${ }^{21}$ PERRONE-MOISÉS, Cláudia. Direito internacional penal. Barueri: Manole, 2012. p. 130.

${ }^{22}$ Dois exemplos podem ser mencionados no que tange o reconhecimento do direito à verdade, como causa de pedir no processo civil e penal. No Brasil, o caso da família Teles, o Tribunal de Justiça do Estado de São 
princípios e da própria atividade estatal tem provocado mudanças também na ordem interna. Assim, o direito internacional tem influenciado o reconhecimento do direito à verdade pelos ordenamentos internos. A atividade jurisdicional também percorre o mesmo caminho no sentido de fortalecer o direito à verdade e o conhecimento dos fatos a partir de demandas de vítimas, familiares e outros interessados.

Mas, não se pode ignorar o fato de que mesmo diante do direito de saber, o poder judiciário caracteriza-se por sua atividade limitada pela inércia. Assim, sua atuação depende da provocação dos interessados e de um processo rigidamente dialético de produção de provas, contraprovas, afirmações e contestações. O processo judicial é também marcado pelo caráter individualizado, orientado por uma atuação casuística. Mesmo quando diante de demandas coletivas, é da natureza da atividade jurisdicional estabelecer um recorte da realidade. Será analisado individualmente cada caso, que pode eventualmente envolver mais interessados, mas nunca será possível uma análise sistemática de todo um contexto social em que tenham ocorrido violações em larga escala.

Cumpre lembrar, portanto, que mesmo diante da possibilidade de adjudicação para o reconhecimento do direito à verdade, outros mecanismos também podem prestar uma importante contribuição, como é o caso das comissões da verdade, por oferecer uma visão abrangente de todo um contexto. Nesse sentido as comissões da verdade têm um importante papel, pois permitem um meio alternativo à instância judicial para resolução de conflitos. Seu modus operandi é diverso e seus fundamentos também. As comissões da verdade permitem que se conciliem os anseios da coletividade, como direitos individuais. Permitem uma abordagem holística, que considera vítima, acusado, estado e sociedade.

O que se deve extrair disso tudo é que, para lançar-se no estudo do direito à verdade é necessário, antes de tudo, compreender que essa verdade à qual se refere diz respeito aos acontecimentos e portanto difere do conceito de verdade jurídica. É necessário porém reconhecer que mesmo a verdade factual pode ser estabelecida através da via judicial, tal como ocorre com a verdade jurídica. Portanto, não existe nenhum empecilho de ordem fundamental ao reconhecimento do direito à verdade pela poder judiciário. É certo, no entanto, que algumas peculiaridades que caracterizam a via jurisdicional podem levar à conclusão de que nem sempre esse será o meio mais adequado ao estabelecimento

Paulo reconheceu em sentença declaratória que as vitimas mencionadas no processo foram torturadas e em decorrência sofreram danos físicos e morais. Na Argentina, a Corte Suprema reconheceu o direito de saber os acontecimentos não através do processos penal, mas através do Habeas Data. Vide: PERRONE-MOISÉS, Claudia. Direito internacional penal. Barueri: Manole, 2012. 
da verdade factual. Essencialmente, não se pode perder de vista o fato de que a verdade factual, embora guarde relações com a verdade jurídica, com ela não se confunde, sendo necessário manter essa diferenciação sempre em perspectiva.

\subsection{O avanço dos direitos humanos e o reconhecimento do direito à verdade}

O direito à verdade resulta de uma construção histórica, onde elementos de direito internacional e ordem local se entrelaçam. Com efeito, para poder compreender o atual conceito de direito à verdade é necessário traçar o longo processo pelo qual passou seu desenvolvimento e os principais fatores que o erigiram ao centro das discussões de direitos humanos.

\subsubsection{Direitos humanos em construção: a perspectiva histórica e a luta pelos direitos}

A afirmação da existência de um direito à verdade ainda é sujeita a questionamentos e controvérsias, que se exacerbam quando se pugna por sua autonomia. Seu reconhecimento, suas dimensões e implicações resultam de uma construção relativamente recente. Diferentemente de outros direitos individuais e coletivos que encontram o respaldo do positivismo normativo típico do estado nacional, para que se compreenda as origens do direito à verdade é preciso primeiramente despir-se da visão de que o direito corresponde unicamente às normas positivadas. É preciso partir de uma perspectiva do diálogo intercultural, bem como da historicidade e da luta pelos direitos, sob o risco de se negar a profundidade inerente ao tema.

O reconhecimento da historicidade dos direitos humanos e da perspectiva da luta pelos direitos permite que novos direitos sejam afirmados. Esses fenômenos reafirmam o papel dos juristas como transformadores das relações e atribui-lhes maior responsabilidade. Ao mesmo tempo, a retomada de acontecimentos funestos e de novas violações de direitos humanos, também coloca em evidência o papel e a responsabilidade dos juristas, numa realidade dinâmica que engendra avanços e ao mesmo tempo retrocessos. 
O direito informa e é constantemente informado por outras esferas, como a sociologia, a filosofia e até mesmo a tecnologia. Nesse sentido, a tradição jurídica é constantemente renovada. As mudanças no seio da sociedade são apreendidas pelo direito, que se transforma de maneira a manter-se vivo. ${ }^{23} \mathrm{O}$ direito, portanto mantém uma relação constante de mútuas influências com outras áreas do conhecimento. Há um dinamismo próprio que deve ser contrabalanceado com a necessidade de estabilização das normas. A respeito desse dinamismo histórico assinala Fábio K. Comparato, "a ideia de que indivíduos e grupos humanos podem ser reduzidos a um conceito ou categoria geral, que a todos engloba, é elaboração recente da história". ${ }^{24}$ Assim, é possível traçar a linha evolutiva da fundamentação dos direitos humanos, naquilo se chama historicidade dos direitos.

Os movimentos que marcaram a história dos direitos humanos podem ser analisados a partir de diferentes imagens de tempo. Quando se estuda a história e o desenvolvimento da humanidade vêm à tona essencialmente duas visões: uma visão cíclica atribuída sobretudo ao pensamento grego e uma visão linear, típica da modernidade. A visão cíclica contém em si a ideia de repetição, na medida em que as vivências humanas são esquecidas e por isso é natural que haja uma eterna volta ao passado. ${ }^{25}$ Por outro lado, a visão linear traduz a ideia de continuo progresso, no sentido da evolução histórica. É possível observar movimentos pendulares da ciência, em um ou noutro sentido, ao longo do desenvolvimento da humanidade.

A análise do tempo a partir de uma visão linear ou cíclica também pode informar a compreensão no campo dos direitos humanos.Com efeito, a afirmação histórica dos direitos humanos remete a essa ideia de linearidade histórica e simultaneamente contém um caráter cíclico. Conforme assinala Paolo Rossi, é possível a "presença simultânea das duas imagens numa mesma cultura e num mesmo pensador". ${ }^{26}$ Portanto, o desenvolvimento dos direitos humanos aponta em um sentido geral de aprimoramento e implementação cada vez maiores. Ao mesmo tempo, é marcado por crises que colocam em cheque as conquistas adquiridas.

23 BERMAN, Harold J. Direito e revolução, a formação da tradição jurídica ocidental. São Leopoldo: Unisinos.

${ }^{24}$ COMPARATO, Fabio K. A afirmação histórica dos direitos humanos. São Paulo: Saraiva, 2010, p. 24.

${ }^{25}$ ROSSI, Paolo. O passado, a memória, o esquecimento. São Paulo: UNESP, 2010.

${ }^{26}$ Idem. p. 125. 
O desenvolvimento dos direitos humanos já pode ser identificado desde a Grécia Antiga, passando pelos pensadores do cristianismo, bem como pelos ideais Kantianos e as Revoluções Francesa e Americana. O reconhecimento desses direitos deu-se no seio do estado nacional, a partir de uma perspectiva do direito positivo. Conforme assinala Celso Lafer:

\begin{abstract}
O processo de asserção histórica destas duas gerações de direitos humanos [individuais e econômicos, sociais e culturais], que são direitos de titularidade individual, foram inspirados pelo legado cosmopolita e universalista do liberalismo e do socialismo. Ocorreram, no entanto, na moldura ex parte populi da soberania nacional, consoante o modelo da Revolução Francesa, ou seja, foram conjugados no âmbito de um espaço que consagrava um direito popular de titularidade coletiva: o principio das nacionalidades. ${ }^{27}$
\end{abstract}

Ao atrelar o reconhecimento desses direitos à nacionalidade, a perda da cidadania leva a uma negação de direitos. Para dialogar com o pensamento de Hannah Arendt, o isolamento do homem - sua retirada da esfera política - torna-o invisível, tal como ocorreu com o extermínio do povo judeu durante o regime nazista, que foi antes de mais nada destituído de sua qualidade de cidadão. Assim, o homem tornou-se supérfluo. A apropriação da visão positivista pelos regimes totalitários colocou em evidência a fragilidade do ser humano. As atrocidades cometidas levaram a uma reflexão profunda sobre o papel do direito.

Conforme assinala Norberto Bobbio, diante da negação de direitos aos indivíduos pelos estados, somente a extensão dessa proteção num grau mais elevado - o da comunidade internacional - pode superar a relação de forças entre a opressão e a resistência. ${ }^{28}$ A necessidade de desenvolvimento de uma linguagem universalizante, para além do paradigma da proteção oferecida pelo estado nacional, levou assim ao surgimento da ONU e dos mecanismos de proteção do indivíduo no plano internacional, que inauguraram uma nova fase na proteção dos direitos humanos.

Essa pretensão universalizante porém não impediu o surgimento de novas violações. Daí, por exemplo, o grande choque que o mundo sofreu com os massacres em Ruanda (1994), pois acreditava-se que a experiência da Segunda Guerra Mundial servira como lição à humanidade. Entretanto, o que se viu foi um novo genocídio, retornando ao

${ }^{27}$ LAFER, Celso. Hannah Arendt - Pensamento, persuasão e poder. São Paulo: Paz e Terra, 2003.

${ }^{28}$ BOBBIO, Norberto. A era dos direitos. Rio de Janeiro: Elsevier, 2004, p. 31. 
trauma, que acreditava-se havia sido superado. A historia da humanidade é farta em exemplos de novas violações em larga escala. Simultaneamente, porém, é possível também citar inúmeros casos e exemplos de elevação no grau de respeito e implementação desses direitos, por exemplo com os processos de democratização que marcaram os anos 90 e com o estabelecimento do Tribunal Penal Internacional.

A lógica universalizante, porém, encontrou forte resistência por parte do relativismo cultural. Nesse sentido, o reconhecimento e garantia dos direitos humanos em um mesmo período histórico encontram enorme discrepância entre as diversas localidades, refletindo assim a diversidade social e cultural. Portanto, além do aspecto temporal que permeia o desenvolvimento dos direitos humanos, a diversidade cultural e geográfica também imprimem maior complexidade à temática, que não pode ser olvidada.

Com efeito, a construção dos direitos humanos fundamenta-se sob a centralidade do indivíduo, que caracteriza as sociedades ocidentalizadas. Conforme assinala Norberto Bobbio: "a doutrina filosófica que fez do individuo, e não mais da sociedade, o ponto de partida para a construção da doutrina moral e do direito foi o justnaturalismo, que pode ser considerado, sob muitos aspectos (e foi certamente nas intenções de seus criadores), a secularização da ética cristã (etsi daremos non esse deum)" ${ }^{29}$ A influência da ética cristã nessa construção teórica naturalmente não teve o mesmo impacto em sociedades cuja tradição filosófica é distinta. A ausência dessas raízes comuns, leva ao que Huntington chamou de choque das civilizações, retratando as diferentes visões de mundo. Assim, a discrepância dos fundamentos filosóficos e culturais das sociedades ocidentalizadas e as não ocidentalizadas ensejam também uma diferente interpretação e compreensão dos direitos humanos. ${ }^{30}$

Sob esse ponto de vista, comumente adota-se a justificativa de que na realidade os direitos humanos nada mais são do que uma imposição de valores ocidentais, refletindo o embate entre universalismo e relativismo cultural. Se por um lado, a história do ocidente reflete a desmistificação do mundo e a conquista de direitos civis que caracterizou a Revolução Francesa, as sociedades asiáticas são marcadas por uma disciplina organizada,

\footnotetext{
${ }^{29}$ BOBBIO, Norberto. A era dos direitos. Rio de Janeiro: Elsevier, 2004, p. 55.

${ }^{30}$ Em linhas gerais, as sociedade ocidentalizadas caracterizam-se pela presença marcante da religião e culturalidade típicos dos países europeus, que se lançaram na empreitada colonizadora e em outras sociedades, que tenham absorvido esses traços marcantes. Em contrapartida, quando se fala em sociedades não ocidentalizadas, trata-se de um amplo conjunto de tradições e culturas locais, como a africana, a asiática e a islâmica, que na realidade guardam grandes diferenças entre si. O elemento comum dessas culturas é que sua origem não foi marcada pela lógica cristã.
} 
fruto da lógica confucionista. A lealdade à família e a obediência ao estado são identificados como os dois pilares dessa doutrina. Esses pilares, portanto, permitiriam o florescimento de regimes com tendências autoritárias, uma vez que o senso de comunidade e obediência se sobrepõem à lógica individual que informa os direitos humanos.

Contudo, o discurso de que os direitos humanos representam a lógica e os valores ocidentais vem sendo frequentemente invocado para justificar violações de toda espécie. Essa polarização encobre simultaneamente três importantes elementos da discussão: a própria diversidade da tradição filosófica não ocidental, a possibilidade de um diálogo intercultural, bem como a perspectiva da luta pelos direitos e da resistência.

A esse respeito cumpre retomar a discussão de Amartya Sen, que sustenta ser equivocada a visão de que não há espaço para as liberdades fundamentais nas tradições e nos valores asiáticos. ${ }^{31}$ Pontua que, o primeiro equívoco é identificar os valores asiáticos, como todo homogêneo, quando na verdade há uma enorme variação histórica e social. O segundo equivoco é pensar que não existe na filosofia oriental sustentação à ideia de liberdade e para isso cita diversos textos, que de alguma forma defendem a tolerância e liberdade individual. Por fim, é importante destacar que, a concepção autoritária de valores asiáticos é fruto da interpretação do próprio poder autoritário, que não necessariamente reflete a voz das minorias.

Não é difícil encontrar casos de violações - de violações extremas - da
tolerância em qualquer cultura (das inquisições medievais aos campos de
concentração modernos no ocidente, e da chacina religiosa à opressão
vitimadora do Taliban no Oriente), mas persistentemente se levantam
vozes em favor da liberdade - de diferentes formas - em culturas
distintas e distantes. ${ }^{32}$

Portanto, a justificativa de que os valores asiáticos não comportam os ideais de liberdade inerente aos direitos humanos mostra-se apenas como uma construção de conveniência a serviço do próprio autoritarismo. Mas, ainda que seja possível a construção de direitos humanos a partir da própria tradição filosófica oriental, não se pode escapar ao fato de que a lógica de obediência ao estado e de lealdade à família é marcantemente presente na cultura de muitas dessas das sociedades. Essa característica deve ser considerada, quando se estuda a evolução e efetividade dos direitos humanos. Entretanto,

${ }^{31}$ SEN, Amartya. Desenvolvimento como liberdade. São Paulo: Companhia das Letras, 2012.

${ }^{32}$ Idem, p. 315. 
ela por si só não explica a sociedade não ocidental como um todo e nem toda a sua tradição filosófica. Com efeito, outros referenciais teóricos não ocidentais podem ser usadas em favor de uma compreensão em favor das liberdades individuais, mas por si só não apegam a força da tradição confucionista no continente asiático, que deve ser considerada quando do estudo dos direitos humanos e seus desafios. ${ }^{33}$

Para dialogar com Boaventura de Sousa Santos, todas as culturas possuem concepções de dignidade humana, mas seu conteúdo é bastante variável e nem todas são concebidas em termos de direitos humanos. ${ }^{34}$ Acrescenta ainda que todas as culturas são de certa forma incompletas e problemática em suas concepções de dignidade humana. Daí o diálogo intercultural poder contribuir para o aprimoramento dessa concepção. É possível falar, portanto, em um diálogo de cultura a partir dos diferentes topoi, que marcam cada uma dessas culturas. Com efeito, o fenômeno da globalização e da internacionalização dos direitos humanos permitem esse intercâmbio de culturas e de desconstrução de dogmas. Permitem, ainda o questionamento a estruturas sociais e oferece um importante fórum de diálogo e apoio às minorias.

A tese de que os direitos humanos são na verdade imposição de valores ocidentais pode ser ainda refutada a partir do prisma da luta pelos direitos. Conforme assinala Norberto Bobbio, quando um estado nega aos cidadãos os direitos dignos de proteção resta-lhes a resistência. De acordo com Heynes, os direitos humanos podem ter sua universalidade reconhecida através da luta dos indivíduos e coletividades ao redor do mundo. ${ }^{35}$ As darem voz aos seus anseios e às suas reivindicações, as parcelas mais vulneráveis da sociedade justamente afirmam os valores que reconhecem como lhe sendo inerentes, independentemente do ordenamento jurídico ou estatal. Portanto, não se trata da imposição de um modelo ocidentalizado e sim de uma mudança no sentido ascendente, que nasce a partir das necessidades dos próprios seres humanos. Os direitos humanos engendram, portanto, um papel contra majoritário. Esse papel torna-se evidente diante da contestação e da denúncia.

\footnotetext{
${ }^{33}$ Esse debate é especialmente importante no contexto de Timor-Leste, pois a longa dominação indonésia carregou consigo as concepções de mundo aqui retratadas.

${ }^{34}$ SANTOS, Boaventura de Sousa. Direitos Humanos: o desafio da interculturalidade. In: Revista Direitos Humanos. vol. 02, jun de 2009.

${ }^{35}$ HEYNES, Cristof. A "Struggle Approach" to Human Rights. In: HEYNES, Cristof; STEFISZYN, Karen (edit). Human Rights, Peace and Justice in Africa: a Reader. Pretoria: Pretoria Univeristy Law Press, 2006, p. 15-35.
} 
Aos analisar os direitos humanos sob o prisma da luta pelos direitos, é possível compreender as origens do direito à verdade e como veio a ser reconhecido. Trata-se de um processo que se caracteriza não apenas por ser histórico, mas por engendrar em si a participação dos próprios indivíduos. Foi a partir da luta e reivindicações das vítimas e familiares, que no final do século XX e início do século XXI, no contexto das transições de regimes ditatoriais para regimes democráticos, que se passou a reconhecer o direito à verdade enquanto direito individual. Nessa acepção, possui íntima ligação com o direito ao luto, que deve ser entendido como o direito das famílias em saber sobre o passado de seus entes e as circunstâncias de seu desaparecimento.

O direito à verdade, inicialmente reconhecido em sua dimensão individual, sofreu uma enorme expansão e atualmente defende-se também que seja reconhecido seu caráter coletivo. Nesse sentido, é pressuposto necessário aos estados democráticos. Assim, todo estado fundado na ordem democrática e no direito tem o dever de informar o cidadão a respeito de sua atuação. O direito à informação gera uma obrigação de transparência assegurando-se que os cidadãos, enquanto coletividade, possam ser informados a respeito da atividade estatal. De maneira que o caráter evolutivo dos direitos humanos permite não só a afirmação de novos direitos, mas também a atualização de seu conteúdo e alcance. Com efeito, as normas de direitos humanos, assim como as normas concernentes a outros ramos do direito, operam como organismos vivos influenciados pela ação dos sujeitos de direito internacional, bem como pela atuação das cortes internacionais. A partir dessa perspectiva, é possível compreender evolução, afirmação e expansão do direito à verdade.

\subsubsection{Os novos meios de comunicação e o avanço dos direitos humanos}

As mudanças provocadas pela sociedade da informação e pelos novos meios de comunicação imprimiram uma nova dinâmica na afirmação dos direitos humanos, que não pode passar desapercebida. Esse fenômeno pode ser identificado através do papel exercido pelos novos meios de comunicação, por exemplo, na divulgação de incidentes humanitários e na influência exercida sobre a opinião pública. Pode-se, portanto, identificar uma nova etapa na formação histórica dos direitos humanos, marcada pela troca intensa de informações, pela aproximação entre os interlocutores e vítimas, bem como pelo image making. 
Como exemplo emblemático da influência que os novos meios de comunicação possuem sobre a afirmação dos direitos humanos, está o televisionamento do Massacre de Santa Cruz, ocorrido em 12 de novembro de 1991, em Timor-Leste. Uma grande massa de manifestantes a favor a independência do país foi massacrada pelas tropas indonésias. Entre os presentes que sobreviveram ao ocorrido estavam jornalistas estrangeiros, dentre os quais Max Stahl, que capturou as cenas do massacre em vídeo. As imagens foram então televisionadas no Reino Unido, em 1992. A partir das imagens difundidas ao redor de todo o mundo das graves de violações de direitos humanos perpetradas por agentes da Indonésia, passou a haver forte pressão internacional para investigação das violações e para a causa timorense.

A internet também passa a ter uma crescente importância na aproximação de grupos minoritários, permitindo que dialoguem em fóruns internacionais. As conexões estabelecidas imprimiram um novo sentido à participação da sociedade civil. Ao mesmo tempo, o controle sobre a internet também trouxe novos debates em torno do acesso à informação frente a privacidade.

Há, portanto, um papel inegável dos meios de comunicação no desenvolvimento histórico dos direitos humanos. Os meios de comunicação atuais permitem a junção de forças geograficamente dispersas. Ademais, esses meios também proporcionam a identificação de responsáveis e a responsabilização moral dos estados através do que André Carvalho Ramos chama de power of embarasament, ou seja constrangimento público. ${ }^{36} \mathrm{~A}$ exposição à opinião pública leva a uma espécie de responsabilização moral, que em algumas circunstâncias tem o poder de avançar a proteção dos direitos humanos. Nesse sentido, os novos meios de comunicação potencializam o fenômeno da publicização das ações do estado, mobilizando a sociedade civil.

Apesar do constrangimento público de estados e dirigentes não ser propriamente mecanismo jurídico sancionatório, pode - em determinadas circunstâncias - revelar-se mais efetivo do que as sanções jurídicas no sentido de desestimular condutas lesivas aos direitos humanos. Os novos meios de comunicação social permitem que a população tome conhecimento das ações levadas a cabo pelos estados e o impacto da opinião podem levar à uma mudança de postura em relação às violações. A necessidade de oferecer uma resposta condizente com a pressão da opinião pública pode levar a uma mudança política, no

${ }^{36}$ RAMOS. André de Carvalho. Responsabilidade internacional por violação dos direitos humanos. Rio de Janeiro: Renovar, 2004, p. 321-325. 
sentido de evitar futuras violações e até mesmo de assegurar a responsabilização dos agentes do estado. Assim, a exposição dos fatos e acontecimentos pelos novos meios, sobretudo a internet e a televisão provoca uma transformação no desenvolvimento histórico dos direitos humanos.

O avanço dos novos meios de comunicação também implica uma maior responsabilidade, uma vez que a veiculação de informações falsas e a disseminação de mentiras ferem o direito à verdade e o acesso à informação. Portanto, ao mesmo tempo em que a internet e a televisão imprimem uma nova velocidade aos direitos humanos, também introduzem novos dilemas. Essa temática é especialmente cara ao direito à verdade, já que a verdade factual deve embasar a atividade comunicativa de caráter público.

\subsection{O direito à verdade no contexto da justiça de transição}

O direito à verdade incialmente foi reconhecido no contexto das transições políticas. Atualmente, atribui-se um sentido muito mais amplo a esse direito. Entretanto, é de fundamental importância considerar o direito à verdade à luz da justiça de transição, que em sentido estrito caracteriza-se tanto pelo encerramento de um período de conflitos, quanto pelo fim de estruturas autoritárias.

\subsubsection{As origens da justiça de transição}

As transições políticas carregam consigo uma necessidade inerente de transformação da ordem jurídica, a fim de que esta possa garantir a sobrevivência do novo regime escolhido. A mudança de regime político pode tomar sentidos variados abrindo-se a possibilidade de instalação das mais variadas formas de organização política. Portanto, a queda de um regime autoritário e sua substituição por uma democracia é apenas um dos possíveis cenários de uma transição política. Ademais, a caracterização de um regime político, na prática, pode muitas vezes não ser evidente, já que comumente regimes autoritários transvestem-se de uma falsa legitimidade popular. Mas, independentemente da caracterização do regime anterior e do regime que o substitui, a modificação da organização política, reflete uma mudança na ordem jurídica e de suas instituições. 
Portanto, em uma acepção genérica, justiça de transição não necessariamente tipifica o processo de abandono de regime autoritário em nome de um novo regime democrático.

Entretanto, a terminologia justiça de transição é normalmente empregada na literatura em seu sentido mais estrito: caracterizando a passagem do regime autoritário ao regime democrático ou o fim da fase de conflitos, bem como as implicações advindas desses processos. Portanto, a esse respeito é importante ressaltar que a justiça de transição em sua concepção estrita abrange tanto contextos de repressão autoritária por parte do governo, como contextos de ruptura social, caracterizada pelo conflito armado. Em ambos os casos a justiça de transição marca o encerramento das tensões e a passagem a uma nova etapa nas relações que se estabelecem. Contudo, conforme observa Gonzáles:

Essa distinção baseada na observação de determinada forma de autoritarismo ou de conflito interno, assim como outras generalizaçãos, tem um valor limitado. Há muitos casos híbridos, porque conflitos armados internos muitas vezes resultam da escalada de tensões causadas por um regime opressor... ${ }^{37}$

O autoritarismo, tal como qualquer outro regime político, está sempre resguardado por normas de conduta que garantem a manutenção do sistema. No momento em que essa forma de organização política é abandonada e passa-se à democracia é preciso haver também uma transformação por completo do sistema jurídico, de maneira a garantir o efetivo funcionamento de mecanismos democráticos. Essa transformação não se faz espontaneamente. É preciso um processo - muitas vezes longo - a fim de se desconstruir o ordenamento jurídico anterior até que um novo sistema seja implementado. Daí a necessidade de transformação do próprio direito diante dos processos de democratização. Esses processos engendram em si não apenas a reconstrução das estruturas políticas, mas também de uma mudança social e cultural muito mais abrangente.

Por seu turno, o término da fase de conflito traz consigo também a necessidade de reestruturação das instituições, que frequentemente encontram-se destruídas. Assim, mesmo nos casos de pós-conflito a necessidade de erigir novas bases institucionais, que

37 "However, this distinction is based on observations of a certain type of authoritarian regime and eternal conflict, and, like any generalization, it has limited value. There are many mixed cases, because internal armed conflicts sometimes result from escalating tensions caused by an oppressive regime..." GONZÁLES, Eduardo. Set to fail? Assessing tendencies in Truth Commissions Created after Violent Conflict. In: ICTJ. Challenging the Conventional: Can truth Commissions Strengthen Peace Processes? Jun 2014, tradução livre. Disponível em: <http://www.ictj.org/publication/challenging-conventional-can-truth-commissionsstrengthen-peace-processes $>$ Acesso em: 06.12.2014. 
sejam capaz de absorver os anseios dos diferentes grupos políticos orienta o planejamento dos mecanismos da justiça de transição.

A análise dessas rupturas no ordenamento e das consequências delas advindas traduz-se, portanto, em objeto de estudo do que se convencionou chamar justiça de transição. A justiça de transição caracteriza-se por um processo de abandono dos paradigmas anteriores, que tenham ocasionado violações de direitos humanos e de início de uma nova fase na relação do estado com os indivíduos. É o laço que une o passado repressor à almejada democracia.

Os processos transicionais são tão diversos quanto os regimes e sociedades existentes. Cada processo de transição é marcado por uma história completamente distinta. Ao mesmo tempo, o conceito de justiça de transição permite aproximar essas realidades distantes, podendo-se falar em traços comuns que marcam os processos de democratização. Mesmo diante da dificuldade em se estabelecer com precisão em que se traduz a justiça de transição, justamente por abarcar realidades tão divergentes, é possível afirmar que a justiça de transição é a maneira como esse processo de democratização e de mudança das estruturas estatais é conduzido.

O conceito de justiça de transição é definido pelo Centro Internacional de Justiça de Transição (ICTJ) como: "um conjunto de abordagens e mecanismos destinados a endereçar a questão das violações maciças de direitos humanos ocorridos durante um período de repressão ou conflito". ${ }^{38}$ Em relatório endereçado ao Conselho de Segurança da ONU, o Secretário Geral definiu justiça de transição como: “toda a gama de processos e mecanismos associados a uma tentativa da sociedade para chegar a termos com um legado de abusos cometidos no passado em grande escala, a fim de garantir a prestação de contas, servir a justiça e a reconciliação". 39 A justiça de transição assinala, portanto, essa passagem entre um regime de violência para uma nova etapa de reconstrução dos alicerces da sociedade, que pode ser levada a cabo de maneiras diversas. É justamente essa variedade

\footnotetext{
38 "Transitional Justice refers to a set of approaches and mechanisms designed to address the situation of massive violations of human rights in the Wake of repressive rule or conflict". ICTJ. Transitional Justice in the United Nations Human Rights Council. jun de 2011, p. 2, tradução livre. Disponível em: $<$ http://www.ictj.org/publication/transitional-justice-united-nations-human-rights-council> Acesso em: 01.09.2014.

39 "Comprises the full range of processes and mechanisms associated with a society's attempts to come to terms with a legacy of large-scale past abuses, in order to ensure accountability, serve justice and achieve reconciliation" ONU. Secretary General. Report on the Rule of Law and Transitional Justice in Conflict and Post-conflict Societies. Ago de $2004 . \quad$ Disponível em: $<$ http://www.unrol.org/files/2004\%20report.pdf>Acesso em 01.09.2014.
} 
de mecanismos que tem trazido o estudo da justiça de transição para o centro das discussões de direito internacional e direitos humanos.

Nesse sentido, as comissões da verdade são fio condutores desses processos de transição - são instrumentos dentro de um contexto maior. A enorme diferença nos processos de transição também se traduz em uma grande discrepância entre as comissões da verdade, seu funcionamento, objetivos e resultados. Na mesma medida em que é difícil chegar a uma única definição de justiça de transição, a dificuldade também se estende à conceituação de comissão da verdade.

Compreender em que consiste uma comissão da verdade e o trabalho que ela executa, passa preliminarmente por sua contextualização no âmbito da justiça de transição, que é tão complexo quanto a mudança de regime político que a caracteriza. Jon Elster identifica processos transicionais já na restauração da democracia ateniense, em 411 e 406 a.c., bem como na restauração monárquica da dinastia Bourbon, na França do século XIX $^{40}$ Assim, enfatiza que processos transicionais não são exclusividade da era moderna e nem se limitam a regimes democráticos. A mudança de regime político não é um fenômeno exclusivo da contemporaneidade. Com efeito, a história é repleta em exemplos de quedas de regimes políticos e de sua substituição por novos. Mas o olhar e o estudo dessas transições, sob a perspectiva dos direitos humanos, é muito mais recente.

É possível afirmar que o estudo da justiça de transição tem seu embrião no período após a I Guerra Mundial. A partir de então, o tema foi ganhando força, com as sucessivas redemocratizações ao redor do mundo como: A Revolução dos Cravos, em Portugal em 1974; a redemocratização da América Latina no final dos anos 80; o fim do Apartheid na África do Sul, em 1994 e posteriormente com o fim do regime de Suharto na Indonésia, em 1998. De maneira que a justiça de transição constituiu-se como ramo de estudo cada vez mais complexo, diante das mudanças na política global.

Para Ruti Teitel a genealogia da justiça de transição pode ser divida em três períodos: um que vai do fim da II Guerra Mundial ao início da Guerra Fria, um segundo período que se inicia logo após o fim da Guerra Fria, no fim dos anos 80, seguido do terceiro período, em que a noção de justiça de transição está associada ao que chama de normalização da justiça de transição, que passa a ser um instituto não do estado

${ }^{40}$ ELSTER, Jon. Transitional Justice in Historical Perspective. Cambridge: Cambridge University Press, 2004, p. I. 
excepcional, mas sim a regra geral. ${ }^{41} \mathrm{O}$ primeiro período ficou marcado por uma construção nacional a partir de uma visão internacional com os julgamentos de Nuremberg. O segundo período está associado a soluções que envolvem a comunidade local e as vítimas, enquanto que o primeiro período tinha por foco a responsabilização dos líderes políticos. No terceiro período, assevera Teitel, a justiça de transição deixa de ser uma exceção e passa a estar inserida no contexto de estado estáveis. É isso que chama de normalização.

A partir dessa periodização é possível ter uma visão geral da evolução do tema ao mesmo tempo em que se coloca em perspectiva a transição ocorrida em Timor Leste. O fim da dominação indonésia e a instauração de um novo regime, deram-se no contexto de desmilitarização dos regimes apoiados pelos Estados Unidos durante a Guerra Fria em contraposição à ameaça comunista, refletindo, portanto, o segundo período a que se refere a Ruti Teitel. À retirada das tropas indonésias seguiu-se a construção de um novo estado (statebuilding) timorense, marcado pela influência internacional.

O segundo período na genealogia da justiça de transição foi marcado, sobretudo, pelo dilema entre responsabilização penal e a coesão social trazida pelo estado de direito. De fato, essa dicotomia permanece até hoje no seio das discussões em torno da democracia em Timor-Leste. É possível compreender melhor essa tensão ao se observar que não se trata de um fenômeno isolado, mas reflete uma problemática corrente quando se coloca em foco a teoria e prática da justiça de transição. Assim, é sempre pertinente imprimir um olhar sobre o todo, sobre as próprias limitações da uma justiça de transição a fim de possibilitar uma melhor compreensão dos processos locais.

\subsubsection{Elementos da justiça de transição}

A limitação dos conceitos não permite que se chegue a uma definição conglobante e precisa de justiça de transição, até mesmo porque tem como característica justamente descrever períodos marcados pela incerteza e excepcionalidade. Com efeito, não existe um modelo acabado de justiça de transição. Conforme aponta Priscilla Heyner, existem

41 TEITEL, Ruti G. Transitional Justice Genealogy. In: Harvard Human Rights Journal. v. 16, p. 69 - 94 , 2003, p. 70. Disponível em: <http://www.hcdh-togo.org/documentation/hcdh-26082011151336tjgenealogy.pdf $>$ Acesso em: 30.08.2014. 
possibilidades transacionais e diante delas é necessário fazer escolhas transacionais. ${ }^{42}$ Para isso, é preciso traçar as limitações de cada contexto bem como as necessidades mediatas e imediatas de cada caso. As escolhas transicionais devem levar em conta fatores como a força dos grupos responsáveis pelos abusos, a coesão social e o papel da comunidade internacional. Em razão disso, o estudo de uma justiça de transição compreende não apenas aspectos jurídicos, mas também escolhas políticas e contingências sociais.

Não obstante as diferenças inerentes à justiça de transição, podem ser traçados alguns elementos característicos que encontram uma certa variação na literatura do gênero. Adotam-se aqui os elementos apontados pelo ICTJ, como instituição internacional de referência no estudo da justiça de transição. Os quatro elementos destacados são: responsabilização, reparação, reforma institucional e comissões da verdade. ${ }^{43}$ Cumpre tecer alguns comentários gerais sobre cada um deles, a fim de clarificar os desdobramentos e implicações da justiça de transição. ${ }^{44}$

Ao debruçar-se sobre o tema da responsabilização é preciso delimitar o seu alcance, que pode ir desde a responsabilização por reparação material ou simbólica até a responsabilização penal. A responsabilização penal tem como fio condutor o processo penal, que baseia-se na demonstração da culpabilidade e dos fatos para chegar a uma verdade jurídica. Cumpre a esse respeito retomar a distinção entre verdade factual e verdade jurídica. Um processo de responsabilização penal toma como referência a verdade jurídica. Assim, o processo judicial se presta a uma finalidade distinta daquela que se coloca em relação às comissões da verdade. Com efeito, a responsabilização penal não pode integrar o papel atribuído às comissões da verdade, cujo foco está na elucidação da verdade factual. Essa distinção é fundamental para análise dos sucessos e insucessos de uma política transicional.

A impunidade que permeia grande parte dos processos transicionais, portanto, deve ser analisada a partir dos papéis exercidos por cada um dos elementos da justiça de transição. Assim, repudia-se a frequente crítica às comissões da verdade, no sentido de que elas permitem a impunidade dos agentes. O objetivo que se coloca às comissões da verdade é o esclarecimento dos acontecimentos, tomando-se por base a verdade factual, enquanto que a responsabilização penal compete a tribunais, sejam eles nacionais,

\footnotetext{
${ }^{42}$ HEYNER, Priscilla B. Unspeakable Truths. New York: Routledge, $2^{\mathrm{a}}$ ed, 2002, p. 17.

${ }^{43}$ ICTJ. Disponível em: <http://ictj.org/about/transitional-justice> Acesso em: 02.05.2014.

${ }^{44}$ Cada um desses elementos e especialmente sua interação com a comissão da verdade será analisado à luz do contexto de Timor-Leste no capítulo 3.
} 
internacionais ou híbridos. Essas finalidades distintas não estão em relação de oposição ou de substituição. Ao contrário, trata-se de uma relação complementar entre: responsabilização e esclarecimento e reconhecimento dos fatos.

Um processo de responsabilização penal que não tome por base o revanchismo ou a mera vingança orienta-se pela verdade jurídica, que para ser alcançada deve respeitar regras processuais e de julgamento. Essas limitações processuais se devem essencialmente a duas ordens: uma que diz respeito ao próprio papel do provimento jurisdicional e outra que reflete as conquistas de direito humanos e garantias individuais. Quando se analisa a responsabilização penal de agentes por violações de direitos humanos, cumpre retomar a discussão a cerca do processo penal e das garantias processuais. Tais garantias surgiram justamente em oposição ao autoritarismo estatal, a fim de garantir um julgamento mais justo, assim como o contraditório. Essas garantias individuais são reconhecidas como direitos humanos fundamentais. $\mathrm{O}$ que se vê, porém, é uma tendência atual a relativizar tais regras, sobretudo diante da guerra ao terror. As novas formas de organização da violência têm trazido uma série de indagações a cerca da rigidez das garantias processuais penais. Há uma forte inclinação atual no sentido de prever mecanismos judiciais e de investigação que possam fazer frente às novas formas de violência, reinterpretando as garantias processuais. É natural que esse novo olhar sobre o processo penal gere polarizações entre aqueles que sustentam a necessidade de se preservarem as garantias individuais e aqueles que defendem a releitura e renovação das regras processuais.

Questionamentos similares vêm sendo feitos no que toca à justiça penal internacional, que tem como foco investigar e julgar os crimes contra a humanidade. Isso porque, quando se está diante das graves violações de direitos humanos, sobretudo quando praticadas por chefes de estado de regimes autoritários, as garantias clássicas do processo penal podem revelar-se ultrapassadas ou desarrazoadas, afinal o seu propósito inicial era justamente oferecer garantias o indivíduo contra a arbitrariedade estatal. No momento em que essa regra é utilizada para assegurar a própria arbitrariedade, ela pode revelar-se descabida e descolada de sua própria finalidade. Tal assunto vem sendo objeto de intensos debates entre aqueles que defendem acima de tudo as garantias processuais penais e os que defendem a necessidade de garantir a punição aos agentes que violaram sistematicamente os direitos humanos.

Essa dicotomia, ao lado de questões políticas que permeiam os períodos de transição leva a uma dificuldade de garantir processos éticos e que ao mesmo tempo sejam 
capazes de promover uma justiça efetiva. Nesse sentido, a responsabilização dos agentes de estado por violações de direitos humanos revela-se um verdadeiro desafio na atualidade. A garantia da não impunidade é essencial na construção dos novos alicerces da sociedade pós-conflito. A nova ordem depende da garantia de justiciabilidade e deve estar ancorada em um regime que respeite os direitos humanos para que não se torne incoerente com o próprio sentido de democratização.

Ao confrontar a garantia da não impunidade, com a realidade, revela-se um quadro perturbador. Ainda que a preocupação em punir os agentes responsáveis pelas violações de direitos humanos seja intrínseca à justiça de transição, e por isso mesmo um elemento desta, nem sempre há a efetiva imposição da sanção correspondente. Essa constatação trouxe a preocupação em se elaborar mecanismos adequados para garantir que os crimes contra a humanidade não saiam impunes. Como resultado desse esforço foram criados tribunais internacionais, tal como ocorreu com Ruanda e na antiga Iugoslávia. A história demonstrou que a proteção dos direitos humanos restrita ao paradigma do estado nação é insuficiente, tornando os mecanismos internacionais imprescindíveis à proteção do ser humano.

A primeira previsão de um tribunal internacional de que se tem notícia, remonta ao Tratado de Versalhes, de 1919, que previu que os derrotados na I Guerra Mundial fossem julgados por tribunais internacionais em razão de seus crimes. Entretanto, a responsabilidade individual pelos crimes da I Guerra Mundial jamais chegou a efetivar-se.

A noção de responsabilidade criminal no âmbito internacional foi posteriormente fortalecida com a criação dos tribunais de Tóquio, Nuremberg, Ruanda, bem como pelo Tribunal Penal Internacional (TPI). Todos têm e tiveram em comum o objetivo de responsabilizar os agentes pelas gravíssimas violações de direitos humanos, diante da impossibilidade de processamento no âmbito nacional. Essa dimensão do direito internacional, com vínculo mais direto com o direito das gentes, busca a responsabilização de indivíduos por atos de guerra, agressão e ilícitos internacionais. Ultrapassam a ideia de crime comum, pois além da agressão ao bem jurídico individual, existe uma agressão ao gênero humano como um todo. Portanto, possuem uma transcendência para além do caso concreto.

Em razão das funções que desempenhadas pelo direito penal, foi eleito para os casos de graves violações a direito humanos. Nesse ponto há uma confluência mútua entre direito penal e direito internacional. Mireille Delmas-Marty aponta que o direito penal 
pode através de um universalismo de valores estabelecer um maior equilíbrio no processo incessante de globalização. ${ }^{45}$ Para ela "o direito penal pode contribuir para reordenar os poderes políticos, econômicos e jurídicos e reequilibrar valores monetários e não monetários". ${ }^{46} \mathrm{O}$ direito penal elege aqueles bens que irá proteger. Nesse sentido: a humanidade é o bem digno de maior proteção. De fato, o direito penal permite colocar padrões éticos mínimos na esfera internacional. Assim, há uma influência cada vez maior entre direito penal e direito internacional. Nesse contexto aparecem os tribunais internacionais ad hoc e o próprio Tribunal Penal Internacional. A responsabilização penal, portanto, é um elemento de extrema importância para compreensão e análise de uma justiça de transição.

Embora seja possível afirmar que, o foco de trabalho do TPI e dos Tribunais ad hoc criados consiste na responsabilização penal individual, os trabalhos por eles desenvolvidos envolveram em grande medida o estabelecimento da verdade a partir das evidências produzidas no curso do processo de investigação. ${ }^{47}$ Com efeito, apesar de seus trabalhos implicarem o estabelecimento de uma verdade jurídica, o material, documentação e testemunhos levantados também contribuem para a garantia do direito à verdade, em sua acepção fatual, pois trazem à luz do debate as violações de direito humanos perpetradas.

Nesse sentido, a criação do TPI através do Tratado de Roma de 1998 veio a fortalecer os mecanismos de justiça de transição. Embora o TPI seja o único organismo internacional permanente com competência para estabelecer a responsabilidade individual por violações de direitos humanos, coexiste com outras importantes instâncias internacionais que contribuem para o avanço e proteção dos direitos humanos. Como exemplos importantes a serem mencionados, as cortes regionais de direitos humanos: a Corte Interamericana de Direitos Humanos (CIDH), a Corte Europeia de Direitos Humanos

45 DELMAS-MARTY, Mireille. Le droit penal comme éthique de la mondialisation. In: Annales Internacionales de Criminologie. v. 41, n.1-2, 2003.

46 DELMAS-MARTY, Mireille. Le champs pénal.In: Mélanges en l'honneur du professeur Reynald Ottenhof. Paris: Dalloz, p. 1.

${ }^{47}$ Nesse sentido: "The UN Security Council designed the ICTY in such a way that it had jurisdiction to adjudicate the criminal responsibility of perpetrators. Implicit in this jurisdiction was that such a tribunal would adjudicate based upon the truth as revealed by a careful examination of credible and reliable evidence. Although

it might be argued that peace and security would have been equally served by a more comprehensive factfinding process such as a truth commission, the Security Council placed the truth-finding process within the walls of a courtroom in which individual criminal responsibility would be determined." GROOME, Dermot. The Right to Truth in the Fight Against Impunity. In: Berkeley Journal of International Law. 175, vol. 29, 2011, p. $186 . \quad$ Disponível em: $<$ http://scholarship.law.berkeley.edu/cgi/viewcontent.cgi?article=1401\&context=bjil $>$ Acesso em: 20.11.2014. 
(CEDH) e o Tribunal Africano de Direitos Humanos e dos Povos (TADHP), cujo objetivo primordial é a proteção dos direitos humanos, tendo em vista a responsabilização estatal. No continente asiático, porém, a proteção regional dos direitos humanos por meio de instâncias regionais é ainda incipiente. No âmbito da ASEAN (Associação de Nações do Sudeste Asiático) foi criada a Comissão Intergovernamenal de Proteção aos Direitos Humanos que elaborou a Declaração da ASEAN de Direitos Humanos, em 2012. Entretanto, a comissão não possui as mesmas competências que as comissões homólogas presentes nos demais sistemas regionais. ${ }^{48}$ Essa constatação ilustra de maneira simbólica a percepção do papel e o sentido atribuído aos direitos humanos em cada região.

As variações regionais não restringem a importância dessas instituições e as contribuições prestada no avanço dos direitos humanos. Com efeito, as cortes regionais têm demonstrado o seu papel inovador. Especificamente no que toca o direito à verdade, a Corte Interamericana de Direitos Humanos teve um papel fundamental para o seu reconhecimento a partir de uma interpretação sistêmica da Convenção Americana de Direitos Humanos. Ainda que se trate de um mecanismo regional, é certo que sua atuação tem efeitos expansivos, no sentido de informar o direito internacional como um todo.

As referidas cortes regionais de direitos humanos, diferentemente do TPI não possuem competência para responsabilização individual. De maneira que se prestam a estabelecer a responsabilidade estatal. Ainda sim, a responsabilização estatal constitui importante precedente para uma eventual responsabilização criminal dos agentes estatais. Contribui na medida em que produz material probatório e reconhece a existência de violações.

Nesse sentido, também a Corte Internacional de Justiça (CIJ), embora não seja propriamente uma corte de direitos humanos, oferece uma significativa contribuição para esse campo, ao estabelecer a responsabilidade dos estados por violação de direitos humanos praticadas por seus agentes. No caso Congo versus Uganda a CIJ reconheceu a responsabilidade do estado reclamado por violações cometidas em território congolês. ${ }^{49}$ Assim, determinou a obrigação de reparação por parte de Uganda, em razão dos atos cometidos por suas tropas em 1998, quando ocupava o território do país vizinho. Portanto,

\footnotetext{
${ }^{48}$ É importante notar que Timor-Leste tem como um dos principais objetivos de sua agenda política, integrar o bloco regional e conta com o apoio da Indonésia para o pleito. Atualmente a ASEAN é composta por: Tailândia, Filipinas, Malásia, Singapura, Indonésia, Brunei, Vietnã, Myanmar, Laos e Camboja.

49 Julgamento em 19.12.2005. Disponível em: <http://www.icj-cij.org/docket/files/116/10455.pdf> Acesso em: 11.08.2014.
} 
embora a CIJ não seja competente para estabelecer a responsabilização penal, a jurisprudência por ela elaborada tem o condão de influenciar a postura adotada pelos estados. Portanto, a responsabilização penal caminha paralelamente à responsabilização do estado, sendo que ambos constituem duas facetas complementares da luta contra a impunidade.

Com efeito, o TPI convive também com outros tribunais internacionais, tribunais nacionais e tribunais híbridos cada um com suas peculiaridades, finalidades e modos de operar próprios, o que não implica a diminuição do seu papel, que ainda sim simboliza um novo paradigma na ordem mundial. No contexto transicional, especialmente diante da fragilidade institucional que marca esse período, a tutela internacional dos direitos humanos e a estrutura do TPI constituem um importante mecanismo para fazer frente às dificuldade do estado nacional em garantir o combate à impunidade, superando o paradigma nacionalista da proteção dos direitos humanos. Entretanto, diante da impossibilidade de acionamento do TPI, existem ainda uma série de outros mecanismos que podem também ser utilizados para assegurar ou ao menos pressionar na direção da responsabilização. ${ }^{50}$

Portanto, faz-se imprescindível a harmonização e coexistência das distintas formas de responsabilização. A fragmentariedade da ordem internacional conduz à necessidade de diálogo entre as cortes, no sentido de fortalecer os mecanismos de proteção dos direitos humanos e de direito humanitário. Há uma relação de complementaridade das diversas instâncias no combate à impunidade.

Paralelemente à responsabilização penal existe ainda a responsabilidade por reparação. $\mathrm{O}$ dever de reparar abriga a ideia de reconhecimento do mal infligido às vítimas e de mecanismos que busquem restaurar sua dignidade. O dever de reparação leva à imposição de obrigações ao estado, e eventualmente a indivíduos, em relação às vítimas e seus familiares assim como em relação à coletividade. A violação de direitos humanos

\footnotetext{
${ }^{50}$ A escolha por um ou outro modo carrega consigo uma escolha prévia entre prosseguir com o julgamento dos crimes ou promover a anistia. Trata-se de uma escolha política perversa, pois a realidade demonstra que em alguns casos a transição para a democracia seria inviabilizada se não estivesse acompanhada de uma anistia. Por outro lado, a omissão da responsabilização penal pode ter efeitos ainda mais perversos na construção do novo paradigma democrático. Enquanto alguns países optaram expressamente pela anistia, como foi o caso do Brasil, outros realizaram uma espécie de anistia silenciosa, por não promoverem o julgamento dos responsáveis ao mesmo tempo em que também não foi aprovado nenhum instrumento isentando-os da responsabilidade. Foi o caso da Indonésia, que até hoje não proporcionou um julgamento efetivo dos agentes responsáveis por violações de direitos humanos em seus territórios e em Timor-Leste, apesar da instalação de um tribunal com essa finalidade, que foi considerado pela comunidade internacional como um simulacro.
} 
enseja o direito à reparação, que pode ser atribuído ao estado na medida em que tenha ativamente contribuído para tal, ou caso tenha se omitido. Isso porque, as obrigações de direitos humanos implicam um dever de respeito, proteção e promoção pelo estado. Portanto, ainda que a violação não tenha sido diretamente perpetrada pelo estado, a violação do dever de proteção leva à sua responsabilização. $\mathrm{O}$ desrespeito a qualquer um dos três deveres acarreta a responsabilização pelo estado, que não exclui uma possível reparação devida pelo autor da violação.

De acordo com os Princípios e Diretrizes sobre o Direito a Recurso e Reparação para Vítimas de Graves Violações do Direito Internacional dos Direitos Humanos e Graves Violações do Internacional Humanitário, aprovado pela Assembleia Geral da ONU, as reparações podem ser feitas na forma de restituição, compensação, reabilitação, satisfação ou garantias de não repetição. ${ }^{51}$

A restituição implica restaurar a situação da vítima anterior à violação. Ocorre que, nas violações de direitos humanos essa restituição torna-se muitas vezes impossível. Assim, permite-se a compensação, que deve ser proporcional à gravidade e indenizar os danos causados, o que inclui o dano moral, bem como outros aspectos econômicos, como tratamentos de saúde e perdas de propriedade. A reabilitação, por sua vez, consiste no tratamento médico, psicológico e na prestação e serviços sociais. O conceito de satisfação, por seu turno, é mais abrangente e inclui por exemplo medidas efetivas para que cessem as violações, bem como a verificação dos fatos e revelação da verdade. Também se compreende por satisfação a localização de pessoas desaparecidas e declarações oficiais no sentido de restaurar a dignidades e reputação das vítimas. O perdão público, o tributo às vitimas e a produção de material educacional e didático, reconhecendo as violações também integram o conceito amplo de satisfação. A garantia de não repetição também é um conceito abrangente que inclui, por exemplo o controle civil das forças armadas, o fortalecimento do poder judiciário, educação para direitos humanos e mecanismos de prevenção de conflito, entre outras medidas.

As reparações podem ser divididas em dois grandes grupos: reparações materiais e reparações simbólicas. O marco referencial que se tem a respeito de reparações materiais é o exemplo da Alemanha no pós II Guerra Mundial, que além de pagar indenizações ao 
estado de Israel, também pagou milhares de indenizações a título individual. ${ }^{52}$ No Brasil, por exemplo, as reparações materiais foram inicialmente atribuídas a partir da judicialização de demandas. Em seguida, a Comissão de Anistia do Governo Federal passou a conceder essas reparações em sede administrativa. Na África do Sul, foi estabelecido um programa de reparações materiais extremamente criticado pela lentidão na análise dos pedidos. ${ }^{53}$ No caso de Timor-Leste não houve um programa geral de reparações, apesar das políticas de assistência social aos ex-combatentes, mas nunca em razão da condição de vítima do conflito.

A responsabilidade por reparar pode recair tanto sobre estados, quanto sobre indivíduos. Mas, é sobretudo, a responsabilidade dos estados que interesse neste estudo, como resultado da macrocriminalidade estatal, de que fala Kai Ambos. No que se refere à responsabilidade de reparação, as comissões da verdade podem ser importantes mecanismos de reparação simbólica por parte dos estados e podem também prever o pagamento de indenizações às vitimas, como foi o caso da Comissão de Verdade e Reconciliação da África do Sul (TRC). Paralelamente, podem também as comissões da verdade, promover programas de reabilitação, promovendo a reintegração social. Ademais, as comissões da verdade podem também servir como mecanismo de satisfação ao revelar a verdade e os acontecimentos, como foi o caso da CAVR. São também garantias de não repetição, pois produzem materiais disponíveis à educação para direitos humanos. Ademais, quando as comissões da verdade, por si só não são capazes de promover essas reparações, podem fazer recomendações às instituições competentes.

Ao debruçar-se sobre o tema das reparações surge ainda o debate em torno do sujeito passivo dessa obrigação. Tanto estados quanto indivíduos têm direito à reparação. A reparação aos estados está fundada em normas de direito internacionais. ${ }^{54}$ As reparações devidas aos indivíduos vítimas de violações de direitos humanos fundam-se nas obrigações internacionais de respeito aos direitos humanos. É essa a perspectiva mais relevante do ponto de vista da justiça de transição. Pode-se ainda falar em reparações a uma certa

\footnotetext{
${ }^{52}$ ELLIS, Mark S. HUTTON, Elizabeth. Policy Implications of World War II Reparations and Restitution as Applied to the Former Yugoslavia. In: Berkeley Journal of International Law. Vol. 20, 2002, p. 342-354. Disponível em: $\quad<$ http://scholarship.law.berkeley.edu/cgi/viewcontent.cgi?article=1218\&context=bjil> Acesso em: 07.09.2014.

53 TRC. Truth and Reconciliation Committee Final Report. 2003. Disponível em: $<$ http://www.justice.gov.za/trc/report/> Acesso em: 07.09.2014.

${ }^{54}$ Partindo-se dessa visão, existem fortes argumentos no sentido de que o estado indonésio tem o dever de reparar o estado timorense. Mas, conforme será analisado no capítulo 3, não houve nenhuma tentativa de buscar reparações por parte do estado de Timor-Leste.
} 
comunidade ou coletividade, que não se confunde com a reparação de um estado a outro estado, baseada na soberania e igualdade dos estados na ordem internacional.

Além da responsabilização criminal e por reparações, a justiça de transição caracteriza-se ainda pelo elemento da reforma institucional, que deve refletir os novos paradigmas políticos da sociedade. A reforma institucional carrega consigo uma série de medidas como a reforma das leis, do sistema judiciário, dos órgãos de representação e de fiscalização. Por sua complexidade, representa uma mudança a longo prazo e muito mais difusa. Tratam-se de uma série de medidas, que levam ultimamente a uma mudança de mentalidade: do autoritarismo à democracia. A reforma institucional idealmente abriga também uma reforma dos quadros administrativos, ao excluir de sua atividade indivíduos que tenham perpetrado graves violações de direitos humanos.

Ainda em relação à reforma institucional, as comissões da verdade, identificadas como quarto elemento da justiça de transição, simbolizam uma mudança na concepção de tais estruturas, uma vez que trazem ao debate público o papel e atuação do estado. As comissões da verdade refletem a necessidade de reforma institucional e surgem como uma alternativa à justiça tradicional, ao incorporarem o conceito de justiça restaurativa. Enquanto os métodos judiciais de solução de conflitos têm como paradigma o punitivismo estatal e a concepção individualista de direitos e deveres, as comissões da verdade podem ser consideradas uma espécie de alternativa. Entre o punitivismo e o esquecimento, as comissões da verdade revelam seu papel de reconstrução das estruturas sociais. Nesse sentido, as comissões da verdade, são a alternativa não violenta para que se apurem os fatos passados, não deixando que caiam no esquecimento. As comissões da verdade permitem que se funde um poder cooperativo, desprendendo-se dos padrões de violência. ${ }^{55}$

Quando surgiram os primeiros mecanismos de justiça de transição, as comissões da verdade eram vistas como subterfúgios para evitar a responsabilização penal. Essa visão, hoje parece ultrapassada, uma vez que as comissões contribuem em grande medida para possibilitar alguma forma de responsabilização. Assim, comissões da verdade podem abrir caminhos para a responsabilização criminal. Passou-se portanto de uma visão de alternatividade para uma visão de complementariedade.

${ }^{55}$ SHAFFER, Matthew Shaffer. An Arendtian Analysis of the Truth and Reconciliation Commission. In: The Yale Review of International Studies. v. 03, 2012. Disponível em: http://yris.yira.org/essays/833. Acesso em: 12.02.2013. 
Em que pese serem as comissões meios alternativos de solução de conflito isso não lhes retira exigência de independência e imparcialidade. A transparência da comissão e a publicidade de seus atos, portanto, são formas de garantir o controle social. Assim, é possível fiscalizar se a atuação da comissão segue a exigência de independência, bem como o cumprimento das demais regras impostas para seu funcionamento. De fato, instituir uma comissão que atue de maneira obscura e revanchista é uma contradição inerente, uma vez que seu fim é justamente esclarecer abusos estatais cometidos contra os indivíduos.

As comissões da verdade têm como característica o estabelecimento de um espaço para empoderamento das vítimas. Trata-se de um conceito elementar quando se estudam as comissões da verdade. Em sua origem, as comissões da verdade surgem como um mecanismo de reequilíbrio das relações entre vítima e autor. Inserem-se em um conceito de justiça restaurativa, que deve ser entendida como um processo em que vítima e ofensor são envolvidos de forma ativa na resolução dos conflitos. O objetivo é a reintegração e a responsabilização. ${ }^{56}$

As comissões, de maneira geral, procuram esclarecer fatos ocorridos durante um período de autoritarismo ou de conflito interno, através produção de registros. Mas, é preciso enfatizar que não necessariamente são precedidas por regimes ditatoriais ou pelo autoritarismo estatal. A Comissão da Verdade e Reconciliação do Canadá, por exemplo, busca esclarecer violações de direitos dos povos indígenas nas escolas residenciais. A ocorrência desse tipo de violação, mesmo em estado democráticos, demonstra que as comissões da verdade não se restringem a contextos de justiça de transição. Assim, é muito mais adequado caracterizar as comissões da verdade como mecanismos de esclarecimento e estabelecimento da verdade em período de violações de direitos humanos. Todo documento, se propõe a retratar algo ou alguma coisa. Ao documentar algum acontecimento este é sempre orientado a algum interlocutor, qualquer que seja ele e procura explicar algum fenômeno. Os trabalhos desenvolvidos por uma comissão a verdade, o trabalho de documentação e de recolha de arquivos e testemunhos, está orientado a uma finalidade: o esclarecimento de violações de direitos humanos.

Comissões da verdade foram implementadas em diversos países, com objetivos, estruturas e em contextos variados. Alguns exemplos são: a Comissão para Verdade e

56 ONU. ECOSOC. Basic principles on the use of restorative justice programs in criminal matters. Resolução 2000/14. Disponível em: $<$ www.unicef.org/lac/spbarbados/Legal/global/CP/Basic\%2520principles\%2520restorative\%2520justice\%25 20 criminal $\% 2520$ matters.doc $+\& c d=4 \& \mathrm{hl}=$ en $\& \mathrm{ct}=\mathrm{clnk} \& \mathrm{gl}=$ br\&client=safari $>$ Acesso em: 07.08.2014. 
Reconciliação da África do Sul; Comissão para o Esclarecimento Histórico na Guatemala e a Comissão de Verdade e Reconciliação em Serra Leoa. De acordo com dados do Centro Internacional para Justiça de Transição (ICTJ), mais de quarenta comissões da verdade foram criadas desde a Comissão Nacional Argentina para Desaparecidos, de $1983 .^{57} \mathrm{Em}$ que pese a diversidade das comissões, é possível identificar algumas características comuns presentes nas diferentes comissões instaladas. De acordo com Priscilla Heyner, comissões da verdade podem ser definidas de acordo com quatro critérios: o foco no passado, o objetivo de investigar um padrão de abusos cometidos durante certo período de tempo, ao invés de um evento específico, uma instituição temporária, cuja intenção é concluir um relatório final e, por fim, o fato de ser oficialmente autorizada ou instituída pelo estado. $^{58}$

Portanto, de uma maneira geral as comissões da verdade, possuem competências de investigação a respeito de um determinado período ou evento em que tenham ocorrido violações de direitos humanos. Conforme pontuado por Cláudia Perrone-Moisés:

Talvez se esteja vivendo uma época em que é possível encontrar um lugar entre
o perdão e a punição. As comissões da verdade e reconciliação podem ser
entendidas como espaços onde as vítimas, seus familiares e a sociedade têm a
possibilidade de tentar se reconciliar com o passado, ao compreender o que
aconteceu, fazendo com que possamos sentir-nos de novo em casa no mundo ${ }^{59}$

Seu papel não se confunde com o do poder judiciário, pois fundamenta-se em razões diversas. As comissões da verdade têm por finalidade o esclarecimento da verdade factual. Devem portanto, ter um mandado por prazo determinado. As comissões da verdade, são um elemento importante para a efetivação de uma justiça de transição e coexistem com outros, fortalecendo-se mutuamente. Cada realidade demonstra uma maior ou menor fragilidade em relação a cada um dos elementos destacados (responsabilização, reparação, reforma institucional e comissões da verdade). Entretanto, o que sobressai é que só podem ser compreendidos quando estudados à luz de sua relação de sinergia que se estabelece. O estudo da justiça de transição exige um panejamento integrado e complementar, conforma aponta o Relatório sobre Estado de Direito e Justiça de Transição

57 GONZÁLES, Eduardo. Drafting a Truth Commission Mandate. A Practical Tool. ICTJ, 2013, p.1.Disponível em: <http://ictj.org/sites/default/files/ICTJ-Report-Drafting Mandate-Truth-Commission2013_0.pdf $>$ Acesso em: 13.06.2013.

${ }^{58}$ HEYNER.Priscilla. Unspeakable Truths. New York: Routledge, $2^{\mathrm{a}}$ ed, 2002, p. 11.

${ }^{59}$ PERRONE-MOISÉS, Cláudia. Direito internacional penal: Imunidades e Anistias. Barueri: Manole, 2012, p. 85 . 
em Sociedades de Conflito e de Pós-conflito, elaborado pelo Secretário Geral da ONU. ${ }^{60}$ Portanto, compreender os trabalhos de uma comissão da verdade passa pela compreensão holística de que uma justiça de transição é composta por outros elementos, que influenciam e são influenciados pelas comissões da verdade.

\subsubsection{Mudanças de regime e a construção democrática}

O imperativo da verdade revela-se como fundamento da própria democracia, que sustenta-se na ideia de prestação de contas ao povo enquanto detentor da soberania popular. Assim, a construção de um novo regime democrático, exige que de alguma forma se prestem satisfações à população em relação às violações de direitos humanos ocorridas. Toma-se aqui essa satisfação em um sentido amplo, significando a necessidade de revelar e reconhecer os abusos cometidos.

É importante reconhecer que o direito à verdade não se resume a contextos de transição. Ao contrário, o direito à verdade é pressuposto de qualquer estado democrático, inclusive de democracias consolidadas. É que o direito à verdade deriva da própria concepção democrática e de estado de direito e por isso seu âmbito de discussão não se limita à justiça de transição. Assim, todo cidadão tem direito a ter conhecimento sobre a atuação estatal, a fim de que possa fiscalizar o uso do poder. O direito à verdade é, assim, imprescindível ao debate público. Sem esse debate, sem a liberdade de exprimir e trocar ideias, não há que se falar em democracia.

Mas é durante a fase de transição para a democracia, que o direito à verdade revela-se como elemento essencial na superação do autoritarismo. É a partir do estudo da justiça de transição que nasce o ideal de direito à verdade. Isso porque o regime autoritário deixa inúmeras questões em aberto, questionamentos não respondidos, sombras do passado. Cercado pela mentira e pelo segredo, o autoritarismo não tem espaço para a verdade factual. Assim, no momento em que esse autoritarismo é substituído por um regime democrático as questões em aberto devem ser esclarecidas e os fatos devem ser trazidos à luz. Por isso, a justiça de transição traz consigo a reivindicação pela verdade dos fatos e o reconhecimento da atuação estatal perante a sociedade. Mas, a revelação da

${ }^{60}$ ONU. Secretary General. Report on The rule of law and transitional justice in conflict and post-conflict societies.S/2004/616, 03 de ago de 2004. Disponível em: $<$ http://www.unrol.org/doc.aspx?n=2004+report.pdf $>$ Acesso em: 11.09.2014. 
verdade, não se reduz a um único olhar sobre os fatos ocorridos durante um passado autoritário. Com efeito, não se prega a estatização da verdade, mas pugna-se pelo reconhecimento dos fatos por parte do estado.

Nesse sentido, o direito à verdade para além de refletir um direito individual, como inicialmente fora reconhecido nos tratados internacionais, também é elemento essencial na formação do estado democrático de direito. Funciona, portanto, como um pilar sobre o qual se fundamenta a relação entre o estado e a sociedade.

\subsection{O direito à verdade na ordem internacional}

$\mathrm{O}$ direito à verdade tem sua gênese no direito humanitário, mas posteriormente ampliou-se para abranger também situações de não conflito. Passou, então, a ser reconhecido por cortes regionais de direitos humanos a partir da interpretação sistêmica das previsões insculpidas nos tratados. Nesse sentido, o direito à verdade surge como um importante mecanismo de satisfação das vítimas e familiares de pessoas desaparecidas.

\subsubsection{O reconhecimento do direito à verdade}

O direito à verdade é reconhecido de maneira implícita e explícita através de inúmeros instrumentos internacionais. Vem ganhando cada vez mais a atenção por parte de estudiosos, na esteira do destaque atribuído ao tema da justiça de transição. Essa crescente importância informa e ao mesmo tempo é informada por uma proliferação de mecanismos garantidores do direito à verdade e de interpretações ampliativas das previsões de direitos humanos. Nesse diapasão, podem ser identificados instrumentos de direito internacional geral e também instrumentos regionais que permitem concluir pelo reconhecimento do direito à verdade. A partir de uma interpretação ampliativa da Declaração Universal de Direitos Humanos é possível identificar o direito à verdade fundado na liberdade de expressão e no livre acesso a informações. Prevê em seu artigo XIXI:

Todo ser humano tem direito à liberdade de opinião e expressão; este direito inclui a liberdade de, sem interferência, ter opiniões e de procurar, 
receber e transmitir informações e ideias por quaisquer meios e independentemente de fronteiras.

A liberdade de opinião e expressão traduz-se no direito de receber e transmitir informações. Nesse sentido, os estados têm a obrigação de garantir o acesso à informação, incluindo aquelas que dizem respeito à sua própria atuação. Com isso, é garantido o direito de conhecimento dos fatos, tornando-os de domínio público. Implica também a garantia de reconhecimento de violações de direitos humanos praticadas ao abrigo estado. Conforme assinala Cláudia Perrone-Moisés:

O conhecimento consiste na verdade dos fatos que, a partir da evidência acumulada, já não pode ser negada. O reconhecimento, a seu turno, é uma espécie de transformação que sofre a verdade histórica, quando assumida de forma oficial pela sociedade e pelo estado. Trata-se de impedir que se possam negar determinados fatos relacionados a atrocidades cometidas a exemplo do que ocorre com o "negacionismo", no caso do Holocausto e, em muitos países da América do Sul, no que se refere aos abusos não reconhecidos pelas ditaduras militares. ${ }^{61}$

Portanto, o direito à verdade se desdobra por um lado, na garantia de tornar público os fatos, e por outro, na admissão dos acontecimentos por parte do estado. Essas duas dimensões caminham lado a lado, complementando-se a fim de permitir a fiscalização por parte da população e a atribuição de responsabilidades, ao identificar as violações e seus responsáveis. Não se trata, portanto, de atribuir ao estado o poder de construir uma verdade uníssona e inconteste. $\mathrm{O}$ direito à verdade, implica a admissão pelo estado das verdades relativas ao envolvimento de agentes estatais em violações de direitos humanos. Tais fatos devem ser de amplo acesso à população de maneira a garantir a publicidade dos atos cometidos pelo estado ou ao abrigo deste.

O direito à verdade foi inicialmente reconhecido em documentos fruto da necessidade de localização e de se obter informações a respeito do desaparecimento de pessoas. O Protocolo adicional I da Convenção de Genebra - que entrou em vigor em 07

\footnotetext{
${ }^{61}$ PERRONE-MOISÉS. Claudia. Imunidades de chefes de Estado e crimes internacionais. Tese (Livre Docência) - Faculdade de Direito, Universidade de São Paulo, São Paulo, 2009, p. 89.
} 
de dezembro de 1979 - prevê em seus artigos 33 e 34 a obrigação da parte em um conflito de procurar e identificar o paradeiro de pessoas desaparecidas. ${ }^{62}$

A Convenção de Genebra de 1949, enquanto ponto nevrálgico do direito internacional humanitário (jus in bellum) e que procura estabelecer regras mínimas a serem seguidas durante um conflito armado, surgiu como uma resposta ao período sombrio vivido durante as duas grandes guerras. Não se confunde com o direito de guerra (jus ad bellum), que disciplina as hipóteses em que o uso da força pode ser admitido e se debruça sobre temas como guerra justa, guerra de agressão e legítima defesa. Enquanto o direito de guerra se preocupa em analisar as causas dos conflitos e sua justificativa, o direito internacional humanitário preocupa-se em disciplinar situações de conflito já existentes, no sentido de garantir alguns parâmetros mínimos de proteção às vítimas e a preservar a população civil. Portanto, o primeiro tratado internacional que prevê expressamente o direito de obter informações sobre pessoas desaparecidas surge no seio do direito humanitário. $^{63}$

\footnotetext{
${ }^{62}$ Artigo 33 - Pessoas desaparecidas

1 - Desde que as circunstâncias o permitam, e o mais tardar a partir do fim das hostilidades ativas, cada Parte no conflito deve procurar as pessoas cujo desaparecimento tiver sido assinalado por uma Parte adversa. A citada Parte adversa deve comunicar todas as informações úteis sobre essas pessoas, a fim de facilitar as buscas.

2 - A fim de facilitar a recolha das informações previstas no número precedente, cada Parte no conflito deve, relativamente às pessoas que não beneficiem dum regime mais favorável em virtude das Convenções ou do presente Protocolo:

a) Registar as informações previstas no artigo $138 .^{\circ}$ da Convenção IV sobre as pessoas que tiverem sido detidas, presas ou de qualquer outra forma mantidas em cativeiro durante mais de duas semanas devido às hostilidades ou à ocupação, ou que tenham morrido durante um período de detenção;

b) Na medida do possível, facilitar e, se necessário, efetuar a procura e registo de informações sobre essas pessoas se tiverem morrido noutras circunstâncias devido a hostilidades ou ocupação.

3 - As informações sobre as pessoas cujo desaparecimento foi assinalado em aplicação do $n .^{\circ} 1 \mathrm{e}$ os pedidos relativos a essas informações serão transmitidos diretamente ou por intermédio da Potência protetora, da Agência Central de Pesquisas do Comité Internacional da Cruz Vermelha, ou das Sociedades Nacionais da Cruz Vermelha e do Crescente Vermelho. Quando essas informações não forem transmitidas por intermédio do Comité Internacional da Cruz Vermelha e da sua Agência Central de Pesquisas, cada Parte no conflito procederá de maneira que elas também sejam fornecidas à Agência Central de Pesquisas.

4 - As Partes no conflito esforçar-se-ão por acordar sobre as disposições que permitam às equipas procurar, identificar e retirar os mortos nas zonas dos campos de batalha; estas disposições podem prever, em caso de necessidade, que essas equipes sejam acompanhadas por pessoal da Parte adversa quando desempenharem a sua missão nas zonas que estiverem sob controlo dessa Parte adversa. O pessoal dessas equipas deve ser respeitado e protegido quando se consagrar exclusivamente a tais missões.

${ }^{63}$ Cumpre a esse respeito distinguir o direito internacional humanitário e os direitos humanos internacionais. O direito internacional humanitário se presta a regular situações de conflito, aos quais se aplica a Convenção de Genebra. Por outro lado, os direitos humanos internacionais constituem-se um corpo de regras e princípios operantes em qualquer circunstância, de guerra ou paz. São o núcleo fundamental de proteção ao ser humano, são os direitos reconhecidos como inalienáveis e intrínsecos a todos os indivíduos.
} 
Importante esclarecer que, mesmo em períodos de conflito, a aplicação de regras do direito internacional humanitário não anula as regras de direitos humanos internacionais. A Corte Internacional de Justiça firmou entendimento no sentido de que:

De maneira geral, a Corte considera que a proteção oferecida pelas
convenções de direitos humanos não cessa em caso de conflito armado,
salvo através do efeito das provisões para derrogação, como aquela
encontrada no artigo $4{ }^{\circ}$ do Pacto Internacional sobre os Direitos Civis e
Políticos. Assim, no que respeita à relação entre o direito internacional
humanitário e o direito dos direitos humanos, há três situações possíveis:
alguns direitos podem ser exclusivamente questões do direito
internacional humanitário; outros podem ser exclusivamente matéria de
direito dos direitos humanos; outros ainda podem ser questões de ambos
os ramos do direito internacional. A fim de responder à pergunta que lhe
foi colocada, a Corte terá que levar em consideração estes dois ramos do
direito internacional, ou seja, dos direitos humanos e, como lex specialis,
o direito internacional humanitário.

As obrigações de direitos humanos internacionais, portanto, continuam a ser exigíveis mesmo em tempos de conflito, porém, o direito internacional humanitário se sobrepõe a elas, ao estipular regras especiais. As obrigações de direitos humanos podem ser suspensas em duas circunstâncias. A primeira delas diz respeito às próprias previsões dos tratados de direitos humanos, que permitem a suspensão de alguns direitos em determinados contextos. $\mathrm{O}$ direito à liberdade de expressão, por exemplo, pode ser limitado em situações específicas, como o estado de emergência.

A segunda circunstância em que as normas de direitos humanos podem ser suspensas verifica-se nos casos em que o direito internacional humanitário prevê outra norma específica. Por se tratar de lex specialis, prevalece sobre as normas gerais de direitos humanos internacionais. Por isso, é necessário compreender os direitos humanos internacionais e o direito internacional humanitário de maneira sistêmica, uma vez que mesmo diante de um conflito armado, as regras de ambos os ramos coexistem.

\footnotetext{
64 "More generally, the Court considers that the protection offered by human rights conventions does not cease in case of armed conflict, Save through the effect of provisions for derogation of the kind to be found in Article 4 of the International Covenant on Civil and Political Rights. As regards the relationship between international humanitarian law and human rights law, there are thus three possible situations: some rights may be exclusively matters of international humanitarian law; others may be exclusively matters of human rights law; yet others may be matters of both these branches of international law. In order to answer the question put to it, the Court will have to take into consideration both these branches of international law, namely human rights law and, as lex specialis, international humanitarian law." ICJ. Legal Consequences of the Construction of a Wall in Occupied Palestinan Territory.2004, p.178, tradução livre.

Ainda sobre aplicação das normas de direitos humanos a decisão da ICJ no caso Legality of the Threat or Use of Nuclear Weapons, n. 26.
} 
A necessidade de localização de pessoas desaparecidas aparece primeiramente na Convenção de Genebra, constituindo-se a partir do direito internacional humanitário. Todavia, o direito à localização de pessoas desaparecidas não se limita ao jus in bellum. Conforme apontado, é necessário proceder a uma análise holística do tema. Embora o direito à verdade tenha sua gênese no jus in bellum, passa a ser reconhecido também como regra de direitos humanos devendo ser respeitado tanto em tempos de conflito quanto em tempos de paz. A previsão contida no Protocolo I da Convenção de Genebra abriu a discussão em torno do direito à verdade, fazendo com que a obrigação de localizar pessoas desaparecidas também em tempos de paz fosse posteriormente reconhecida.

A emergência do direito à verdade e a extensão da obrigação de localizar pessoas desaparecidas também em períodos de não conflito se deve em grande medida à atuação da Corte Interamericana de Direitos Humanos. Embora se trate de um mecanismo regional de jurisdição contenciosa e consultiva, seus trabalhos tiveram grande impacto no reconhecimento do direito à verdade no campo dos direitos humanos internacionais, contribuindo para avanços significativos sobre o tema, em razão de sua atuação paradigmática.

Por diversas vezes confrontada com o crime de desaparecimento de pessoas no contexto latino americano, a CIDH firmou uma ampla jurisprudência acolhendo o direito à verdade, a partir de uma interpretação sistemática da Convenção Americana de Direitos Humanos. ${ }^{65}$ Em 1989, no caso Velásquez Rodríguez VS Honduras, reconheceu o direito dos familiares em saber o destino das vítimas ou o local onde se encontram seus restos mortais. ${ }^{66}$ Também emblemático, no caso Caso Godinez VS Honduras a Corte firmou entendimento no sentido de que os estados têm a obrigação de buscar a verdade. ${ }^{67}$

Embora a $\mathrm{CIDH}$ reconheça o direito à verdade enquanto garantia individual, decorrente dos artigos $8^{\circ}$ e 25 da Convenção Americana de Direitos Humanos ${ }^{68}$, que

${ }^{65}$ Uma relação ampla e análise dos casos julgados pela CIDH pode ser consultada em PERRUSO, Camila Akemi. O desparecimento forçado de pessoas no sistema Interamericano de Direitos Humanos - direitos humanos e memória. Dissertação (Mestrado em Direito) - Faculdade de Direito, Universidade de São Paulo, São Paulo, 2010.

${ }^{66}$ CIDH. Caso Velásquez Rodríguez VS Honduras. 29.07.1988. Velásquez Rodriguez foi preso pelas forcas armadas sem ordem judicial, em 12 de setembro de 1981. A existência de sua detenção foi negada pelo estado hondurenho.

${ }^{67}$ CIDH. Caso Godinez Cruz VS Honduras.20.01.1989. Godínez Cruz desapareceu em 22 de julho de 1982. Testemunhas afirmam tê-lo visto sendo levado por pessoas com trajes civis e militares.

${ }^{68}$ Artigo $8^{\circ}$ - Garantias judiciais

1. Toda pessoa terá o direito de ser ouvida, com as devidas garantias e dentro de um prazo razoável, por um juiz ou Tribunal competente, independente e imparcial, estabelecido anteriormente por lei, na apuração de qualquer acusação penal formulada contra ela, ou na determinação de seus direitos e obrigações de caráter 
preveêm respectivamente as garantias e proteção judiciais, a dimensão coletiva do direito à verdade também passou a ser ponderada a partir do Caso Bámaca Velásquez VS Guatemala, julgado em 25 de novembro de 2000. ${ }^{69}$ O juiz Hernan Salgado Pesantes destacou em seu voto em apartado:

\begin{abstract}
Disto se segue que, o direito à verdade apresenta - pelo menos até à data um caráter coletivo e abrangente, uma espécie de direito difuso cuja eficácia deve beneficiar toda a sociedade. No entanto, este caráter difuso não impediria - em certas circunstâncias, como o desaparecimento forçado - que a pretensão de obter a verdade seja aclamada por uma pessoa ou uma família ${ }^{70}$
\end{abstract}

civil, trabalhista, fiscal ou de qualquer outra natureza.

2. Toda pessoa acusada de um delito tem direito a que se presuma sua inocência, enquanto não for legalmente comprovada sua culpa. Durante o processo, toda pessoa tem direito, em plena igualdade, às seguintes garantias mínimas:

a) direito do acusado de ser assistido gratuitamente por um tradutor ou intérprete, caso não compreenda ou não fale a língua do juízo ou tribunal;

b) comunicação prévia e pormenorizada ao acusado da acusação formulada;

c) concessão ao acusado do tempo e dos meios necessários à preparação de sua defesa;

d) direito do acusado de defender-se pessoalmente ou de ser assistido por um defensor de sua escolha e de comunicar-se, livremente e em particular, com seu defensor;

e) direito irrenunciável de ser assistido por um defensor proporcionado pelo Estado, remunerado ou não, segundo a legislação interna, se o acusado não se defender ele próprio, nem nomear defensor dentro do prazo estabelecido pela lei;

f) direito da defesa de inquirir as testemunhas presentes no Tribunal e de obter o comparecimento, como testemunhas ou peritos, de outras pessoas que possam lançar luz sobre os fatos;

g) direito de não ser obrigada a depor contra si mesma, nem a confessar-se culpada; e

h) direito de recorrer da sentença a juiz ou tribunal superior.

3. A confissão do acusado só é válida se feita sem coação de nenhuma natureza.

4. O acusado absolvido por sentença transitada em julgado não poderá ser submetido a novo processo pelos mesmos fatos.

5. O processo penal deve ser público, salvo no que for necessário para preservar os interesses da justiça.

Artigo 25 - Proteção judicial

1. Toda pessoa tem direito a um recurso simples e rápido ou a qualquer outro recurso efetivo, perante os juízes ou tribunais competentes, que a proteja contra atos que violem seus direitos fundamentais reconhecidos pela Constituição, pela lei ou pela presente Convenção, mesmo quando tal violação seja cometida por pessoas que estejam atuando no exercício de suas funções oficiais.

2. Os Estados-partes comprometem-se:

a) a assegurar que a autoridade competente prevista pelo sistema legal do Estado decida sobre os direitos de toda pessoa que interpuser tal recurso;

b) a desenvolver as possibilidades de recurso judicial; e

c) a assegurar o cumprimento, pelas autoridades competentes, de toda decisão em que se tenha considerado procedente o recurso.

${ }^{69} \mathrm{CIDH}$. Caso Bámaca Velásquez VS Guatemala. 25.11.2000. Em confronto com as forças da Guatemala, Bámaca Velásquez deasapareceu em 12 de março de 1992.

70 "De lo dicho se desprende que el derecho a la verdade presenta - al menos hasta hoy - un carácter colectivo y general, una espécie de derecho difuso cuya efectividad debe beneficiar a la sociedade toda. Sin embargo, este carácter difuso no impediria - en determinadas circunstancias, como la de la desaparición forzada - que la pretensión a obtener la verdade sea eclamado por una persona o una família". CIDH. Caso Bámaca Velásquez VS Guatemala. Voto em separado de Hernan Salgado Pesantes, tradução livre. Disponível em: <http://www.cidh.oas.org/Indigenas/seriec_70_esp.pdf> Acesso em: 20.11.2014.

No mesmo sentido o voto de Cançado Trindade: "29. Varios pueblos de America Latina han, en sua historia reciente, conocido y sufrido el flagelo y crueldade de la tortura, los tratados inhumanos o degradantes, las 
Posteriormente, no caso Contreras e outros VS El Salvador, julgado em 31 de agosto de 2011, a CIDH firmou entendimento no sentido de que o direito de conhecer à verdade, também implica uma dimensão coletiva, ao afirmar :

a Corte lembra que toda pessoa, inclusive os familiares das vítimas de graves violações de direitos humanos tem, de acordo com os artigos 1.1, 8.1 e 25, bem como, em determinadas circunstâncias, o artigo 13 da Convenção, o direito de conhecer a verdade, motivo por que devem, juntamente com a sociedade, ser informadas sobre o ocorrido... ${ }^{71}$

Assim, o direito à verdade implica o dever do estado em assegurar a verdade histórica. ${ }^{72}$ Há, portanto, uma tendência nos fóruns internacionais que apontam no sentido de se reconhecer a dimensão coletiva do direito à verdade. A atuação da CIDH contribuiu para uma interpretação ampliativa do direito de saber a verdade reconhecendo-o como uma obrigação do estado, não restringindo-o à situação de conflito armado. Isso porque, um grande número de casos julgados pela Corte tem como pano de fundo a sistemática de desaparecimentos forçados adotados pelos regimes militares na América Latina entre os anos 60 e 90. Apesar de se tratar de um mecanismo regional e de um contexto histórico e geográfico específico, as contribuições da $\mathrm{CIDH}$ revelam uma prática comum aos regimes militares da época. O desaparecimento forçado foi amplamente utilizado como tática de manutenção do controle pelos regimes militares que se instalaram nas mais variadas regiões do globo. ${ }^{73}$ Nesse sentido, o reconhecimento do direito à verdade como um direito

ejecuciones sumarias y arbitrarias o extra-legales, y las desapariciones forzadas de personas. La búsqueda de la verdade - como ilustran los casos de desaparición forzada de personas - constituyeelpunto de partida para la libertación ai como la protección del ser humanos sin la verdade (por mas insuportable que esta venga a ser) no es posible libertarse del tormento de la incertitumbre, y tampoco es posible ejercer los derecho protegidos. 30. Enefecto, la prevalência del derecho a la verdade configurse como una condition sine qua non para hacer efectivos el derecho a las garantias judiciales (articulo 8 de la convencion americana) y el derecho a la proteccion judicial (articulo 25 de a convencioón), reforzandose todos mutuamente, en beneficio de los familiares inmediatos de la persona desaparecida. El derecho a la verdade se reviste, así, de dimensiones tanto individual como colectiva."

${ }^{71}$ CIDH. Caso Contreras e outros VS El Salvador. 31.08.2011. O caso diz respeito ao desaparecimento de crianças entre 1981 e 1983, perpetrados por membros de diferentes órgãos militares no contexto de "operações de contrainsurgência" durante o conflito em El Salvador.

72 A respeito do direito à verdade no sistema americano de proteção dos direitos humanos consultar o documento: COMISSÃO INTERAMERICANA DE DIREITOS HUMANOS. Derecho a la verdade en América, 2014. Disponível em: <http://www.oas.org/es/cidh/informes/pdfs/Derecho-Verdad-es.pdf> Acesso em: 06.12.2014.

${ }^{73}$ Só em Timor-Leste, por exemplo, estima-se que tenham ocorrido 18.600 mortes e desaparecimentos forçados, entre 05 de abril de 1974 e 25 de outubro de 1999. CAVR. Relatório Chega! 2005. Disponível em: $<$ http://www.cavr-timorleste.org/po/Relatorio\%20Chega!.htm> Acesso em: 07.03.2012. 
humano também exigível em tempos de não conflito, marca um momento decisivo para a ampliação do direito à verdade.

Além da importante contribuição da $\mathrm{CIDH}$, a temática do direito à verdade também desenvolveu-se a partir de relatórios, diretrizes, resoluções, decisões internacionais, bem como da atuação dos estados em sua ordem interna. Mas, somente em 2010 é que o direito à verdade passou a ser expressamente reconhecido por um tratado internacional de direitos humanos. A Convenção Internacional para a Proteção de Todas as Pessoas contra Desaparecimentos Forçados, que entrou em vigor em 23 de dezembro de 2010, passou a integrar as normas de direitos humanos. Em seu preâmbulo, bem como no artigo 24.2 enuncia o direito das vítimas em saber a verdade sobre as circunstâncias do desaparecimento forçado:

Artigo 24.2. A vítima tem o direito de saber a verdade sobre as circunstâncias do desaparecimento forçado, o andamento e os resultados da investigação e o destino da pessoa desaparecida. O Estado Parte tomará medidas apropriadas a esse respeito.

Mais uma vez, o direito à verdade encontra-se associado ao desaparecimento forçado de pessoas. Desta vez, o direito a obter notícias sobre o desaparecimento vem insculpido não em uma regra de direito humanitário, tal como previsto no Protocolo I da Convenção de Genebra, mas em um tratado de direitos humanos, cuja aplicabilidade se estende a tempos de paz. Em razão da natureza da convenção suas regras aplicam-se a qualquer tempo. Até agosto de 2014, a convenção contava com 43 estados membros. ${ }^{74} \mathrm{~A}$ convenção prevê um comitê específico, o CED (“Committee on Enforced Disappearance”), cuja atribuição consiste em monitorar as obrigações estabelecidas pela convenção, bem como as violações às suas previsões. O reconhecimento expresso do direito à verdade nos tratados internacionais nasce, portanto, em resposta ao crime de desaparecimento forçado.

Além de tais previsões, o direito internacional, enquanto corpo sistêmico, reconhece ainda o direito à verdade por meio de outros mecanismos. Há uma série de princípios, relatórios e decisões elaborados por órgão internacionais, concernente aos direito à verdade. $\mathrm{O}$ direito internacional engendra em si não apenas tratados (hard law),

\footnotetext{
${ }^{74} \mathrm{O}$ status dos estados membros da convenção está disponível no site: <http://indicators.ohchr.org> Acesso em: 04.09.2014.

O Brasil ratificou a convecção em 2010. Timor-Leste, por sua vez não acedeu à convenção.
} 
mas declarações de princípios e práticas internacionais (soft law), que também são fontes do direito internacional.

Nesse sentido, a Assembleia Geral da ONU aprovou os Princípios e Diretrizes sobre o Direito a Recurso e Reparação para Vítimas de Graves Violações do Direito Internacional dos Direitos Humanos e Violações Graves do Internacional Humanitário (Resolução 60/147), no qual prevê o direito à verificação dos fatos e sua total publicidade. ${ }^{75} \mathrm{O}$ direito à verdade emerge assim como núcleo integrante de uma noção abrangente do direito à reparação. ${ }^{76} \mathrm{O}$ perdão e o reconhecimento público dos fatos e da responsabilidade também constituem formas de satisfação das vítimas, assim como à sociedade, reconhecendo-lhes o direito à verdade no que diz respeito às violações ocorridas. No âmbito da Assembleia Geral aprovou-se também a resolução 65/196 de 21 de dezembro de 2010, que institui o dia internacional do direito à verdade e a resolução 68/165 de 18 de dezembro de 2013, que reconheceu o direito à verdade e sua importância no combate à impunidade a na proteção dos direitos humanos.

As resoluções da Assembleia Geral encontram-se amparadas pela legitimidade internacional de que goza o órgão, por abranger a comunidade dos estados. Ao endereçar o tema do direito à verdade, a Assembleia Geral imprime não apenas um maior destaque ao tema, mas assinala também o entendimento de que o direito à verdade não resulta apenas de uma interpretação regional, como aquela elaborada pela CIDH e nem se restringe a tempos de conflitos. Assim, amplia-se o debate em torno do direito à verdade, fortalecendo o entendimento de que se trata de um direito humano fundamental, a ser protegido pela comunidade dos estados de maneira integral. Com efeito, ainda que as resoluções não tenham por si só a mesma força vinculante que os tratados internacionais, apontam no sentido de que tais previsões são aceitas pelos estados como regras de conduta e integram a praxe internacional. Corroboram, portanto, o entendimento em favor do reconhecimento do direito à verdade, ensejando a obrigação estatal de garantia, proteção e promoção.

Paralelamente às resoluções da Assembleia Geral, há ainda uma série de resoluções de órgãos da ONU que também complementam o panorama do direito à verdade no contexto internacional. A esse respeito cumpre mencionar as resoluções da

${ }^{75}$ ONU. AG. Resolução 60/147. A/60/PV.64, em 16.12.2005.

${ }^{76}$ Artigo. 22. Satisfaction should include, where applicable, any or all of the following:

(b) Verification of the facts and full and public disclosure of the truth to the extent that such disclosure does not cause further harm or threaten the safety and interests of the victim, the victim's relatives, witnesses, or persons who have intervened to assist the victim or prevent the occurrence of further violations;

(e) Public apology, including acknowledgement of the facts and acceptance of responsibility 
Comissão de Direitos Humanos relacionadas ao direito à verdade e à justiça de transição: resolução 2005/70 sobre direitos humanos e justiça de transição, resolução 2005/81, sobre o combate à impunidade e resolução 2005/66, sobre o direito à verdade.

Após a substituição da Comissão de Direitos Humanos pelo Conselho de Direitos Humanos, foram aprovadas ainda as seguintes resoluções: 11/12 de 2009 sobre direitos humanos e justiça de transição e 10/26 de 2009, sobre genética forense e direitos humanos. No que diz respeito ao direito à verdade, foram aprovadas as resoluções 9/11 de 2008, $12 / 12$ de 2009 e 21/7 de 2012. Igualmente relacionado ao tema discutido, também são dignas da nota as resoluções 10/10 de 2009 e 14/10 de 2010, ambas sobre desaparecimento forçado. Todas elas oferecem os contornos do direito à verdade e sua inter-relação com outros temas, como justiça de transição e desaparecimento forçado. Essas resoluções ainda servem como orientações gerais para que os estados e órgãos internacionais envidem esforços no sentido de implementação desse direito.

As resoluções, embora não possuam a mesma natureza dos tratados, podem de certa forma pressionar os estados na formulação de tratados ou de políticas que adotem os conceitos insculpidos nas resoluções. As resoluções aprovadas pelo Conselho de Direitos Humanos têm um caráter técnico. Naturalmente que as resoluções aprovadas no seio da Assembleia Geral adquirem maior legitimidade, por se tratar de um fórum bastante amplo. Por outro lado é, em grande medida, a partir do trabalho do Conselho que a Assembleia Geral vota e define diretrizes de direitos humanos. O conjunto das resoluções tem um efeito cumulativo. Nesse contexto, o trabalho do Conselho constitui a linha de frente para o avanço dos direitos humanos.

Além das resoluções mencionadas, foi ainda produzida uma série de relatórios, sobretudo pela Comissão de Direitos Humanos e posteriormente pelo Conselho de Direitos Humanos, que lhe sucedeu. Nesse sentido, o Relatório Joinet, de 1998 foi paradigmático para o reconhecimento do direito a verdade. ${ }^{77}$ Foi elaborado pela Comissão de Direitos Humanos da ONU, por meio de sua Subcomissão para Prevenção de Discriminação e Proteção das Minorias.

O Relatório Joinet é um retrato da luta contra a impunidade por violações de direitos humanos e estabelece três princípios referenciais na proteção dos direitos das vítimas: (1) o direito de saber, (2) o direito à justiça e (3) as garantias de reparações.

${ }^{77}$ ONU. Human Rights Commission.Final report on the Question of the impunity of perpetrators of human rights violations (civil and political).E/CN.4/Sub.2/1997/20/Rev.1, de 02.10.1997. 
Assim, o direito de saber a verdade é um dos princípios orientadores do combate à impunidade. O relatório ressalta que não se trata somente de um direito individual, mas de um direito coletivo, que gera uma obrigação aos estados: um dever de memória. Enquanto direito coletivo, se presta a evitar que os acontecimentos passados se repitam.

O direito de saber implica o direito inalienável à verdade, no dever de estabelecer uma memória histórica, bem como no direito à verdade das vítimas e em garantias de efetivação desses direitos. A primeira versão do relatório estabelece:

\footnotetext{
Todo povo tem direito inalienável de conhecer a verdade sobre os acontecimentos passados e sobre as circunstâncias e os motivos que levaram, de maneira sistemática e através de agraves violação de direitos humanos, à perpetração de crimes hediondos. O exercício pleno e efetivo fazer direito à verdade é essencial para prevenir a recorrência dessas violações no futuro. ${ }^{78}$
}

$\mathrm{O}$ exercício do direito à verdade pode ser efetivado das maneiras mais diversas. $\mathrm{O}$ relatório aponta o papel essencial que comissões de investigação desempenham no combate à impunidade. $\mathrm{O}$ direito de saber implica a preservação a memória, que se traduz em uma dimensão individual e ao mesmo tempo coletiva.

O relatório sofreu revisão em 08 de fevereiro de $2005 .^{79}$ Entretanto, não houve mudanças substanciais no conteúdo fundamental do direito à verdade. A nova versão do relatório dá, porém, nova ênfase às comissões da verdade, valorizando o seu papel. O foco do relatório anterior estava nas comissões de investigação, enquanto que a versão revisada eleva as comissões da verdade como os principais mecanismos de efetivação do direito à verdade. Prevê no princípio 6o estabelecimento e o papel das comissões da verdade:

\footnotetext{
Na medida do possível, as decisões para estabelecer uma comissão da verdade, seus termos de referência e sua composição devem levar em conta uma ampla consulta pública, que considere especialmente o ponto de vista das vítimas e sobreviventes. Devem ser feitos esforços para garantir que homens e mulheres participem das deliberações de forma igualitária. Em reconhecimento à dignidade das vítimas e familiares, as investigações realizadas pelas comissões da verdade devem ser conduzidas com o objetivo de garantir o reconhecimento da verdade, naquilo que tenha sido anteriormente negado. ${ }^{80}$
}

\footnotetext{
${ }^{78}$ Idem.

${ }^{79}$ ONU. Human Rights Commission. Report of theIindependent Expert to Update the Set of Principles to Combat Impunity, Diane Orientlicher. E/CN.4/2005/102/Add.1, de 08.02.2005.

${ }^{80}$ Principle 6: The Establishment and Role of Truth Commissions
} 
Além das comissões da verdade, o relatório aponta também a importância da preservação dos arquivos, como instrumentos para garantia do direito à verdade e à memória. Deve ser garantida não apenas a preservação dos arquivos, mas também a colaboração do órgão responsável por eles, permitindo-se-lhes o livre acesso. Assim, o relatório aponta os diversos mecanismos necessários à garantia do direito à verdade.

Também constitui material relevante ao estudo do direito à verdade o relatório a respeito de direitos civis e políticos, incluindo questões de desaparecimento forçado e execuções sumarias, elaborado pela Comissão de Direitos Humanos da ONU em $2005 .{ }^{81}$ Em linha com os demais documentos internacionais, o relatório enfatiza a necessidade de processo transicionais holísticos e que integrem não apenas mecanismos judiciais e de responsabilização penal, mas também mecanismos que garantem a efetivação do direito à verdade. A grande contribuição dos relatórios consiste não apenas estabelecer o conteúdo do direito à verdade, mas também em sistematizar os mecanismos através dos quais esse direito possa ser efetivado.

Na mesma esteira, o Alto Comissariado de Direitos Humanos da ONU, a pedido do Conselho de Direitos Humanos elaborou relatórios em 2006, 2009 e 2011 sobre direitos humanos e justiça de transição, nos quais aborda o direito à verdade. ${ }^{82}$ As ferramentas para busca da verdade, especialmente as comissões da verdade são mecanismos que contam com o apoio da ONU nos contextos de justiça de transição. Os relatórios apontam que as comissões da verdade têm um importante papel na reintegração de ex-combatentes e podem também incorporar em seus mandatos os direitos econômicos e sociais, conforme ocorreu em Timor-Leste e não endereçando apenas as violações de direito civis e políticos.

\footnotetext{
To the greatest extent possible, decisions to establish a truth commission, define its terms of reference and determine its composition should be based upon broad public consultations in which the views of victims and survivors especially are sought. Special efforts should be made to ensure that men and women participate in these deliberations on a basis of equality. In recognition of the dignity of victims and their families, investigations undertaken by truth commissions should be conducted with the object in particular of securing recognition of such parts of the truth as were formerly denied, tradução livre.

81 ONU. Commission for Human Rights on Civil and Political Rights.Report of the Working Group on Enforced or Involuntary Disappearances. E/CN.4/2006/56 de 27.12.2005.

82 ONU. Office of the High Commissioner for Human Rights. Analytical Study on Human Rights and Transitional Justice.A/HRC/12/18, de 06.08.2009.

ONU. Office of the High Commissioner for Human Rights. Analytical Study on Human Rights and Transitional Justice,Activities Undertaken by the Human Rights Components of the United Nations System. E/CN.4/2006/93, de 07.02.2006.

ONU. Office of the High Commissioner for Human Rights. Human Rights and Transitional Justice. $\mathrm{A} / \mathrm{HRC} / 18 / 23$, de 04.06.2011.
} 
Paralelamente aos relatórios que abordam o tema justiça de transição, de caráter mais abrangente, o Alto Comissariado de Direitos Humanos da ONU também elaborou quatro relatórios que tratam especificamente sobre o direito à verdade em: 2006, 2007, 2009 e $2010 .^{83}$ Já no primeiro relatório, conclui pela autonomia e inalienabilidade do direito à verdade e afirma a obrigação que os estados têm de garantir a efetividade desse direito, tanto em sua dimensão individual quanto coletiva. O segundo relatório analisa o conteúdo do direito à verdade e sua relação com o acesso à justiça, o direito à reparação e o direito à informação. Debruça-se também sobre os mecanismos institucionais para a realização do direito à verdade, tal como as comissões da verdade. Por sua vez, o terceiro relatório discute a efetividade do direito à verdade, bem como a necessidade de se estabelecer mecanismos de proteção às vítimas e testemunhas das violações de direitos humanos. Em um continum, o quarto relatório gira em torno da proteção das vítimas, tanto em juízo, quanto fora. Uma análise atenta dos quatro relatórios permite identificar conceitos e problemas centrais do direito à verdade, como por exemplo a dificuldade em ter acesso à documentação e em garantir a integridade das vítimas e testemunhas.

Com a crescente importância que o tema do direito à verdade ganhou, em 29 de setembro de 2011, o Conselho de Direitos Humanos nomeou relator especial, por um período de três anos, com um mandato para promoção da verdade, justiça, reparação e garantias de não reincidência. ${ }^{84}$ A decisão de nomear um relator especial para o tema, mostra a importância e o reconhecimento internacional que o tema vem adquirindo nas últimas décadas. Foram, assim, elaborados relatórios específicos concernentes a determinados países e também relatórios gerais anuais (2012, 2013 e 2014), que trouxeram grande contribuição ao estudo do direito à verdade.

O primeiro relatório geral enfatiza a necessidade de uma análise holística, que integre a promoção da verdade, justiça, reparação e garantias de não reincidência. Ressalta ainda a relação desses conteúdos com desenvolvimento e segurança. De fato, nos contextos transicionais, a experiência do conflito leva a uma fragilidade de todas as estruturas da

\footnotetext{
${ }^{83}$ ONU. Office of the High Commissioner for Human Rights. Report on the Right to Truth. E/CN.4/2006/91 de 08.02.2006;

ONU. Office of the High Commissioner for Human Rights. Report on the Right to Truth. A/HRC/5/7, de 07.06.2007;

ONU. Office of the High Commissioner for Human Rights. Report on the Right to the Truth. A/HRC/12/19 de 21.08.2009;

ONU. Office of the High Commissioner for Human Rights. Report on Rights on the Right to the Truth. $\mathrm{A} / \mathrm{HRC} / 15 / 33$, de 28.07.2010.

${ }^{84}$ ONU. Human Rights Council.Resolução 18/7.A/HRC/RES/18/7, de 29.09.2011.
} 
sociedade, daí a necessidade de se promover uma reforma institucional.

O segundo relatório tem como foco principal as comissões da verdade e identifica uma enorme expansão no número e no mandato dessas comissões. Aponta também que as comissões da verdade instaladas em contextos pós-conflito possuem desafios muito peculiares em razão das fragilidades políticas e econômicas que caracterizam essas regiões. Por seu turno, o terceiro relatório tem como eixo central a necessidade de persecução criminal pelos crimes cometidos e a participação cada vez mais crescente das vítimas. Com efeito, a responsabilização criminal dos agentes continua a ser um dos maiores desafios da justiça de transição, fruto da influência política e econômica que os perpetradores continuam exercendo, mesmo após a mudança de regime. Os relatórios, por abordarem especificamente o direito à verdade, contribuem para a compreensão de seus desafios e correlação com os demais elementos transicionais.

Ainda no que se refere ao reconhecimento do direito à verdade na ordem internacional, é possível mencionar o relatório elaborado pelo Secretário Geral da ONU, a pedido do Conselho de Segurança, em 2004 sobre o Estado de Direito e a Justiça de Transição nas Sociedades em Conflito ou em Pós-Conflito, que contém uma sessão dedicada à facilitação do processo de narração e de conhecimento da verdade (truth telling), associado ao trabalho das comissões da verdade. ${ }^{85}$ Ademais, o Manual de Práticas das Nações Unidas para a Justiça de Transição, de 2010, reconhece como componentes de uma justiça de transição: a persecução pelos crimes cometidos, a facilitação do direito à verdade, as reparações, a reforma institucional e a consulta nacional. ${ }^{86}$ Estabelece ainda que a efetivação de um direito à verdade, passa pela preservação dos arquivos nacionais, bem como outras importantes providências que dizem respeito à proteção de vítimas e testemunhas.

Os documentos citados, embora configurem-se como recomendações, sendo desprovidos de caráter vinculante, permitem estabelecer os contornos do direito à verdade, suas dimensões e conteúdo. Assim, contribuem para o debate, bem como para o reconhecimento desse direito por parte dos estados. Simultaneamente permitem a identificação dos mecanismos de garantia e das atuais práticas relacionadas ao tema, assim como os desafios em seu desenvolvimento.

85 ONU. Secretary General. The Rule of Law and Transitional Justice in Conflict and Post-conflict Societies.S/2004/616 de 03.08.2004.

${ }^{86}$ ONU. Secretary General. Guidance Note - United Nations Approach to Transitional Justice. março de 2010. 
Deve-se ter em conta ainda que, para além das previsões contidas em tratados e documentos internacionais de ordem geral, outros tratados e convenções regionais também permitem que se identifique a proteção do direito à verdade a partir de uma interpretação ampliativa dos direitos humanos. Assim, pode-se mencionar a Convenção Americana de Direitos Humanos, a Convenção Europeia de Direitos Humanos, bem como a Carta Africana de Direitos Humanos e dos Povos, que embora não façam menção expressa ao direito à verdade, permitem que tal garantia seja extraída a partir da interpretação de seus princípios e previsões expressas.

O direito à verdade, portanto, cuja gênese encontra-se na previsão expressa do Protocolo I da Convenção de Genebra, sofreu uma enorme expansão, tornando-se um conceito que abrange não apenas situações de conflito, mas que deve ser observado em diversos contextos. Mais recentemente o direito à verdade e sua relação com o crime de desaparecimento forçado tomou novos contornos a partir da luta contra o terrorismo. Se anteriormente o crime de desaparecimento forçado caracterizava o modus operandi dos regimes militares, a partir dos anos 2000 passou a ser incorporado como prática por estados democráticos para fazer face à essa nova forma de criminalidade. Assim, evidencia-se que o direito à verdade não é uma preocupação que se restringe a estados autoritários ou a regimes transicionais, mas que permeia toda a relação entre estado e indivíduo. $^{87}$

Ainda que as previsões expressas nos tratados de direito internacional reconheçam o direito à verdade como uma questão ligada ao desparecimento forçado, é necessário reconhecer que seu conteúdo foi ampliado de forma a abranger também outras temáticas como: justiça de transição, desenvolvimento democrático, memória e direito à informação. Essa ampliação se deve em grande medida aos trabalhos desenvolvidos pelas cortes internacionais, pelo Conselho de Direitos Humanos e pela Assembleia Geral da ONU, bem como por organizações não governamentais como o ICTJ. Seus trabalhos contribuem para a edificação e fortalecimento do direito à verdade, demonstrando sua fundamentalidade para a dignidade do homem.

\footnotetext{
${ }^{87}$ A respeito do crime de desaparecimento forcado no contexto do combate ao terrorismo, a decisão do cao El-Masri VS antiga República da Iugoslávia, julgado pela CEDH e discutido mais adiante, no capitulo. 2.3.5.
} 


\subsubsection{A exigibilidade do direito à verdade enquanto obrigação estatal}

Um grande número de documentos internacionais (tratados, sentenças, resoluções e relatórios) aponta no sentido do reconhecimento da verdade enquanto direito humano, seja de maneira expressa, ou de maneira implícita. Esse reconhecimento constitui um grande avanço. Entretanto, conforme assinala Norberto Bobbio:

...uma coisa é proclamar esse direito, outra é desfrutá-lo efetivamente. A
linguagem dos direitos tem indubitavelmente uma grande função prática,
que é emprestar uma força particular às reivindicações dos movimentos
que demandam para si e para outros a satisfação de novos carecimentos
materiais e morais, mas ela se torna enganadora se obscurecer ou ocultar
a diferença entre o direito reivindicado e o direito reconhecido e
protegido.

Portanto, uma análise limitada à identificação dos instrumentos internacionais que reconhecem o direito à verdade tornar-se-ia vazia, se não acompanhada da exame de sua exigibilidade enquanto obrigação estatal. É necessário, assim, identificar em que medida o direito pretendido pode ser exigido.

São frequentes os discursos defendendo que as obrigações de direitos humanos internacionais não passam de postulados éticos, desprovidos de força normativa. Há, naturalmente, uma dificuldade de compreensão do sistema do direito internacional, quando se parte de paradigmas da ordem interna, sobretudo, se considerados os dogmas existentes nos sistemas de civil law. Entretanto, procurar compreender o sistema internacional a partir dessa perspectiva constitui um erro apriorístico. De fato, é impossível analisar e apreender o direito internacional, sobretudo o direito internacional dos direitos humanos, sob o prisma redutor do direito interno. O sistema internacional possui características próprias e que não se reduzem a uma análise superficial da unicidade das fontes.

$\mathrm{Na}$ fragmentada ordem internacional inexiste um único centro irradiador das normas ou mesmo uma unicidade jurisdicional. Portanto, as normas internacionais assumem formas variadas, podendo fundamentar-se também nos costumes e práticas internacionais. Por isso, a interpretação dos direitos humanos internacionais exige que se reconheça a fragmentariedade dessa ordem, bem como suas peculiaridades. Nenhuma

${ }^{88}$ BOBBIO, Norberto. A era dos direitos. Rio de Janeiro: Elsevier, 2004, p. 9. 
análise pode ser feita, sem compreender essa característica intrínseca ao direito internacional. Os céticos associam essa fragmentariedade a um não direito. Sustentam que o fato de não haver centralidade na produção normativa associada à ausência do monopólio da força, por alguma espécie de força policial, tornam o direito internacional um não direito.

Diante dessas críticas, é penitente demonstrar a fragilidade desses argumentos a fim de estabelecer a imperatividade do dever de assegurar o direito à verdade. Primeiramente ressalta-se que a produção normativa mesmo na ordem interna pode ser tão difusa quanto na ordem internacional, seja por meio da presença de diversos órgãos legislativos, com competências sobre o mesmo território, por exemplo nos estados federativos ou descentralizados, seja por meio do poder normativo dos órgãos executivos. Assim, a difusão da produção normativa não é característica unicamente do sistema internacional.

No que diz respeito ao monopólio da força, a ordem interna também guarda semelhanças com o sistema internacional. $\mathrm{Na}$ ordem internacional existem normas que regulam o uso da força, que é autorizado em caso de legítima defesa ou através do Conselho de Segurança da ONU. Por outro lado, em termos pragmáticos, os próprios estados podem fazer uso da força, de forma individual, ou mesmo conjunta, por exemplo através de organizações internacionais. Tal como na ordem interna, esse uso da força pelo estado pode ser legal ou ilegal. Portanto, a inobservância das normas não pode servir como elemento diferenciador para a desconstrução do direito internacional e nem do direito internacional dos direitos humanos. Com efeito, tanto na ordem interna, quanto na ordem internacional, a aderência às normas postas pelo direito afigura-se como um desafio.

Esta breve discussão demonstra que as diferenças entre ordem interna e internacional, que procuram justificar o argumento de que o direito internacional não passa de uma política internacional, são apenas aparentes. Ao contrário, cada vez mais a atuação de órgãos internacionais, a produção normativa internacional e os julgados internacionais, tornam irrefutável a realidade e a força do direito internacional no sentido de impor obrigações aos estados.

Portanto, o argumento de que os direitos humanos internacionais não passam de pretensões políticas ou postulados éticos é refutado pela própria realidade, que demonstra a obrigatoriedade e exigibilidade das normas de direitos humanos internacionais. Os problemas de efetivação encontram-se sem dúvida presentes, assim como estão presentes 
em outros ramos do direito na ordenam interna. Entretanto, a não observância das normas não descaracteriza o direito internacional enquanto instituidor de obrigações para os estados.

A respeito das obrigações internacionais dos estados para com os indivíduos, cumpre retomar o pensamento de Hannah Arendt, no sentido de se construir uma formulação de direitos que supere o paradigma do positivismo atrelado ao estado nação. A partir dessa noção supraestatal universalizante, a soberania estatal é limitada por regras de direitos humanos internacionais, que impõem a garantia de respeito aos seus cidadãos. Assim, geram-se obrigações de ordem internacional aos estados, não apenas em relação uns aos outros, mas em relação ao ser humano.

Nessa mesma linha, Mirrelle Delmas-Marty aponta para a construção de um universalismo de valores, no qual o direito penal tem um papel central de proteção dos valores fundamentais. Assim, não se tratam apenas de postulados éticos, mas de valores protegidos por normas internacionais dotadas de força coercitiva, que impõem obrigações e sanções em caso de descumprimento.

Partindo-se do pressuposto de que o direito internacional pode criar obrigações e de que existem múltiplas fontes normativas no direito internacional cumpre ainda indagar se as normas que reconhecem o direito à verdade são igualmente exigíveis. Há, conforme apontado, uma série de resoluções e tratados que estabelecem o direito à verdade e a respectiva obrigação estatal. Essas previsões, porém, possuem naturezas distintas, ordenadas em função da fonte irradiadora. Os tratados, constituem regras coercitivas (hard law) e por isso diferenciam-se das resoluções, que constituem aquilo que se chama de soft law.

Não há dúvidas de que a força obrigacional que emana dos tratados internacionais vincula a atuação dos estados membros. Mas, a questão que se coloca então é se as obrigações previstas nas resoluções podem também vincular a atuação dos estados. Para responder a essa questão, é preciso partir das fontes do direito internacional. Atualmente, há um relativo consenso quanto à enumeração das fontes presentes no artigo 38 (1) do Estatuto da Corte Internacional de Justiça: tratados, direito costumeiro, normas de jus cogens, princípios gerais do direito, decisões dos tribunais internacionais e a doutrina de direito internacional. 
Embora o direito à verdade seja reconhecido pela Convenção Internacional para a Proteção de Todas as Pessoas contra Desaparecimentos Forçados e pelo Protocolo adicional I da Convenção de Genebra, há ainda uma série de resoluções no âmbito da AG e do Conselho de Direitos Humanos, que auxiliam a determinar o seu conteúdo, funcionando como fontes interpretativas. É possível sustentar que o conjunto de resoluções aponta no sentido do reconhecimento do direito à verdade, como direito costumeiro, ensejando obrigações estatais.

O conceito de direito costumeiro é composto por dois elementos, de acordo com o entendimento da CIJ: uma prática extensiva e uniforme dos estados e a opinion juris, que consiste convicção de uma obrigação jurídica. ${ }^{89}$ A partir desses critérios é possível analisar se o direito à verdade pode, então, ser efetivamente reconhecido como direito costumeiro.

As resoluções da Assembleia Geral da ONU, ao reconhecerem a importância em se respeitar e assegurar o direito à verdade, refletem a percepção dos estados de que se trata de um direito humano fundamental. A reunião de todos os estados membros em único fórum acaba por oferecer maior legitimidade aos seus pronunciamentos, demonstrando a aceitação dos postulados pela generalidade dos estados. Não se trata somente da enunciação de deveres, mas uma análise da realidade leva à inevitável conclusão de que o direito à verdade foi incorporado também na prática dos estados.

A prática internacional no sentido do reconhecimento do direito à verdade é evidenciada pela ampla jurisprudência internacional desenvolvida, bem como pela proliferação de comissões da verdade e o aprimoramento de mecanismos de físcalização da ação estatal. A título exemplificativo, desde 1974, em todo o mundo, foram instaladas mais de 57 comissões da verdade. ${ }^{90}$ Ora, a instalação dessas comissões demonstra que os estados possuem a convicção de que existe uma obrigação de garantir o direito à verdade e os demais direitos que lhe são correlatos.

Ademais, outro elemento que aponta no sentido da consolidação do direito à verdade enquanto direito costumeiro é também a atividade das cortes internacionais. Conforme apontado anteriormente, a Corte Interamericana de Direitos Humanos prestou grande contribuição ao reconhecer de forma paradigmática o direito das vítimas e familiares de saber a verdade em relação ao desaparecimento de pessoas. O julgamento de

${ }^{89}$ MÉGRET, Frederic. Nature of Obligations. In: MOEKLI, Daniel, SHAH, Sangreeta, SIVAKUMARAN, Sandesh. International Human Rights. Oxford: Oxford University Press, 2010.

${ }^{90}$ VAN DER MERWE, Hugo. BAXTER, Victoria. CHAPMAN, Audrey R. Assessing the Impact of Transitional Justice. Washington: United States Institute of Peace, 2009. 
casos como Velásquez Rodríguez VS Honduras e Godínez Cruz VS Honduras, dentre muitos outros, criou um corpo jurisprudencial bastante substancioso no sentido de afirmar o dever do estado em assegurar que as vítimas e familiares tenham informações a respeito de pessoas desaparecidas.

A CIDH reconhece o direito à verdade como um direito reflexo da garantia judicial e da garantia ao recurso efetivo, previstos respectivamente nos artigos $8^{\circ}$ e 25 . Assim, não considera que seja um direito autônomo, conforme apontado no julgamento do caso Blanco Romero VS Venezuela, de 2005. Blanco Romero e outros foram detidos por agentes do estado venezuelano, em dezembro de 1999 e em seguida desapareceram. No julgamento do caso, a CIDH posicionou-se da seguinte maneira, acerca do direito pretendido:

\begin{abstract}
A Corte não considera que o direito à verdade seja um direito autônomo consagrado nos artigos 8,13,25 e 1.1 da Convenção, como alegado pelos representantes e, portanto, não endossa o reconhecimento da responsabilidade do estado a esse respeito. $O$ direito à verdade se fundamenta no direito da vítima ou de seus familiares para a obtenção de esclarecimentos, por parte dos órgãos competentes estado, acerca das violações e responsabilidades correspondentes, por meio da investigação e julgamento. ${ }^{91}$
\end{abstract}

De maneira que a $\mathrm{CIDH}$ reconhece o direito à verdade como direito individual reflexo da garantia judicial e do recurso efetivo. O mesmo entendimento pode ser verificado no caso Barrios Altos VS Peru, julgado em 2001. ${ }^{92}$ Por sua vez, a Comissão Interamericana de Direito Humanos, responsável por trazer os casos perante a Corte, tem

91“'La Corte no estima que el derecho a la verdade sea un derecho autónomo consagrado en los artículos 8 , 13, 25 y 1.1 de la Convención, como fuera alegado por los representantes, y por lo tanto no homologa el reconocimiento de responsabilidade del Estado en este punto. el derecho a la verdad se encuentra subsumido en el

derecho de la víctima o sus familiares a obtener de los órganos competentes del Estado el esclarecimiento de los hechos violatorios y las responsabilidades correspondientes, a través de la investigación y el juzgamiento." Caso Blanco Romero VS Venezuela. 28.11.2005. Disponível em: $<$ http://www.corteidh.or.cr/docs/casos/articulos/seriec_138_esp.pdf $>$ Acesso em: 01.12.2014.

${ }^{92}$ No massacre de Barrios Altos, no Peru, quinze jovens foram mortos por agentes das forças armadas. No caso em apreço a CIDH estabeleceu que: "Enel presente caso, es incuestionable que se impidió a las víctimas sobrevivientes, sus familiares y a los familiares de las víctimas que fallecieron, conocer la verdad acerca de los hechos ocurridos en Barrios Altos.

48. Pese a lo anterior, en las circunstancias del presente caso, el derecho a la verdad se encuentra subsumido en el derecho de la víctima o sus familiares a obtener de los órganos competentes del Estado el esclarecimiento de los hechos violatorios y las responsabilidades correspondientes, a través de la investigación y el juzgamiento que previenen los artículos 8 y 25 de la Convención." Caso Barrios Altos VS Peru. 14.03.2001. Disponível em: <http:/www.corteidh.or.cr/docs/casos/articulos/Seriec_75_esp.pdf> Acesso em: 01.12.2014. 
envidado esforços no sentido de que se reconheça também a dimensão social do direito à verdade. Para parte da Comissão, o direito à verdade consiste em um direito de toda a coletividade, com base no artigo 13 da Convenção, que garante a liberdade de pensamento e expressão. ${ }^{93}$ Assim, o direito à verdade em sua dimensão coletiva consiste na garantia de obter informações acerca da atuação do estado.

Além da importante atuação da CIDH e da respectiva Comissão para o avanço e reconhecimento do direito à verdade, a Corte Europeia de Direitos Humanos também tem se debruçado sobre o tema. Reconheceu o direito à verdade, como uma garantia contra o tratamento desumano, no caso no caso Chipre VS Turquia, julgado em 10 de maio de 2001. Desde 1974 a região norte do Chipre é ocupada pela Turquia, que foi condenada pela $\mathrm{CEDH}$ em razão do desaparecimento de cidadãos greco-cipriotas. $\mathrm{Na}$ oportunidade a CEDH considerou que a ausência de informações acerca das pessoas desaparecidas deve ser considerada uma violação ao artigo $3^{\circ}$ da Convenção Europeia de Direito Humanos, que proíbe o tratamento desumano ${ }^{94}$ :

O contexto global deve ainda estar vivo na mente dos familiares das pessoas cujo destino nunca foi contabilizado pelas autoridades. Suportam a agonia de não saber se os membros da família foram mortos no conflito ou ainda estão na prisão ou, se detidos, já faleceram. O fato de que um número muito substancial de greco-cipriotas tiveram que buscar refúgio no sul aliado à permanente divisão de Chipre devem ser considerados obstáculos muito sérios na busca por informações. A prestação de tais informações são de responsabilidade das autoridades do Estado demandado. Esta responsabilidade não foi abolida. Para a Corte, o silêncio das autoridades do Estado demandado em face das preocupações reais dos familiares das pessoas desaparecidas atinge um nível de

${ }^{93}$ Artigo 13 - Liberdade de pensamento e de expressão

1. Toda pessoa tem o direito à liberdade de pensamento e de expressão. Esse direito inclui a liberdade de procurar, receber e difundir informações e ideias de qualquer natureza, sem considerações de fronteiras, verbalmente ou por escrito, ou em forma impressa ou artística, ou por qualquer meio de sua escolha.

2. O exercício do direito previsto no inciso precedente não pode estar sujeito à censura prévia, mas a responsabilidades ulteriores, que devem ser expressamente previstas em lei e que se façam necessárias para assegurar:

a) o respeito dos direitos e da reputação das demais pessoas;

b) a proteção da segurança nacional, da ordem pública, ou da saúde ou da moral públicas.

3. Não se pode restringir o direito de expressão por vias e meios indiretos, tais como o abuso de controles oficiais ou particulares de papel de imprensa, de frequências radioelétricas ou de equipamentos e aparelhos usados na difusão de informação, nem por quaisquer outros meios destinados a obstar a comunicação e a circulação de ideias e opiniões.

4. A lei pode submeter os espetáculos públicos a censura prévia, com o objetivo exclusivo de regular o acesso a eles, para proteção moral da infância e da adolescência, sem prejuízo do disposto no inciso 2 .

5. A lei deve proibir toda propaganda a favor da guerra, bem como toda apologia ao ódio nacional, racial ou religioso que constitua incitamento à discriminação, à hostilidade, ao crime ou à violência.

${ }^{94}$ Artigo $3^{\circ}$ - Proibição da tortura

Ninguém pode ser submetido a torturas, nem a penas ou tratamentos desumanos ou degradantes. 
gravidade que só pode ser classificado como tratamento inumano, na acepção do artigo 3.Pelas razões acima expostas, a Corte conclui que, durante o período considerado, houve uma violação contínua do artigo 3 da Convenção no que diz respeito aos familiares das pessoas gregocipriota desaparecidas. ${ }^{95}$

De maneira que a CEDH reconheceu o direito de saber a verdade, por considerar que a ausência de informações inflige tratamento desumano aos familiares. ${ }^{96}$ Conforme se depreende, portanto, a fundamentação para o direito de saber encontrada pela Corte Europeia de Direitos Humanos em sua decisão é bastante diversa, daquela pugnada pela CIDH.

Por outro lado, a CEDH ao analisar o crime de desaparecimento forçado no contexto do combate ao terrorismo, deixou de se pronunciar acerca da violação ao direito à verdade. Em decisão de 13 de dezembro de 2012, a CEDH julgou o caso de El-Masri VS antiga República Iugoslávia da Macedônia, no qual o senhor El-Masri, cidadão alemão, foi ilegalmente detido por forças da Macedônia, que o entregaram aos Estados Unidos, sob o argumento de que se tratava de um terrorista. Foi levado ao Afeganistão onde foi torturado e posteriormente solto após a CIA reconhecer que se tratava de um engano. Diante dos fatos, a antiga República Iugoslávia da Macedônia foi condenada pela CEDH. Em sua sentença a CEDH pontuou que:

... a Corte pretende também abordar outro aspecto inadequado sobre a
investigação do presente caso, nomeadamente, o seu impacto sobre o
direito à verdade em relação às circunstâncias relevantes do caso. Neste
contexto, sublinha a grande importância do caso em apreço, não apenas
para o requerente e sua família, mas também para as vítimas de crimes
semelhantes, e para o público em geral, que tem o direito de saber sobre o
ocorrido. A questão da "rendição extraordinária" atraiu a atenção mundial e

95 "The overall context must still be vivid in the minds of the relatives of persons whose fate has never been accounted for by the authorities. They endure the agony of not knowing whether family members were killed in the conflict or are still in detention or, if detained, have since died. The fact that a very substantial number of Greek Cypriots had to seek refuge in the south coupled with the continuing division of Cyprus must be considered to constitute very serious obstacles to their quest for information. The provision of such information is the responsibility of the authorities of the respondent State. This responsibility has not been discharged. For the Court, the silence of the authorities of the respondent State in the face of the real concerns of the relatives of the missing persons attains a level of severity which can only be categorized as inhuman treatment within the meaning of Article 3.

For the above reasons, the Court concludes that, during the period under consideration, there has been a continuing violation of Article 3 of the Convention in respect of the relatives of the Greek-Cypriot missing persons." http://hudoc.echr.coe.int/sites/eng/pages/search.aspx?i=001-59454\#\{"itemid":["001-59454"]\}

${ }_{96}$ Outros casos julgado pela Corte Europeia de Direito Humanos dignos de nota são: Kurt VS Turkey, julgado em 25.05.1998 e no caso Tas VS Turkey, julgado em 14.11.2000, conforme apontado em:

NAQVI, Yasmin. The Right to the Truth in International Law: Fact or Fiction? In: International Review of the Red Cross, vol. 88, n. 862, jun 2006, p. 257. 
provocou questionamentos por parte de organizações internacionais e intergovernamentais, incluindo os organismos de direitos humanos das Nações Unidas, o Conselho da Europa e o Parlamento Europeu. Este último revelou que alguns dos Estados em causa não estavam interessados em revelar a verdade. O conceito de "segredos de Estado" tem sido frequentemente invocado para obstruir a busca da verdade... ${ }^{97}$

Apesar de abordar a discussão em torno do direito à verdade, a $\mathrm{CEDH}$, no caso em apreço, não analisou se houve ou não violação do direito pretendido, com base no artigo 10 da Convenção Europeia de Direitos Humanos, que prevê a garantia da liberdade de expressão. ${ }^{98}$ A CEDH considerou a questão prejudicada, por já haver violação a outros direitos insculpidos na Convenção. Entretanto, o voto em separado dos juízes Tulkens, Spielmann, Sicilianos e Keller, nota que a análise do direito à verdade, efetuada pela Corte foi bastante tímida. Nesse sentido, reconhecem em seu voto o direito à verdade, enquanto garantia decorrente do direito ao recurso efetivo, previsto no artigo 13 da Convenção Europeia de Direito Humanos. ${ }^{99}$

O caso julgado pela CEDH coloca em evidência a atualidade do debate a respeito da necessidade de se assegurar o direito à verdade diante dos desaparecimentos forçados no contexto do combate ao terrorismo. Os votos em apartados aproximam-se da

\footnotetext{
97 “...the Court also wishes to address another aspect of the inadequate character of the investigation in the present case, namely its impact on the right to the truth regarding the relevant circumstances of the case. In this connection it underlines the great importance of the present case not only for the applicant and his family, but also for other victims of similar crimes and the general public, who had the right to know what had happened. The issue of "extraordinary rendition" attracted worldwide attention and triggered inquiries by many international and intergovernmental organizations, including the United Nations human rights bodies, the Council of Europe and the European Parliament. The latter revealed that some of the States concerned were not interested in seeing the truth come out. The concept of "State secrets" has often been invoked to obstruct the search for the truth". CEDH. Case of El-Masri VS The Former Yugoslav Republic of Macedonia.13.12.2013. Disponível em: <http://hudoc.echr.coe.int/sites/eng/pages/search.aspx?i=001115621\#\{"itemid":["001-115621> Acesso em: 21.11.2014.

${ }^{98}$ Artigo $10^{\circ}$ - Liberdade de expressão

1. Qualquer pessoa tem direito à liberdade de expressão. Este direito compreende a liberdade de opinião e a liberdade de receber ou de transmitir informações ou ideias sem que possa haver ingerência de quaisquer autoridades públicas e sem considerações de fronteiras. O presente artigo não impede que os Estados submetam as empresas de radiodifusão, de cinematografia ou de televisão a um regime de autorização prévia. 2. $\mathrm{O}$ exercício desta liberdade, porquanto implica deveres e responsabilidades, pode ser submetido a certas formalidades, condições, restrições ou sanções, previstas pela lei, que constituam providências necessárias, numa sociedade democrática, para a segurança nacional, a integridade territorial ou a segurança pública, a defesa da ordem e a prevenção do crime, a proteção da saúde ou da moral, a proteção da honra ou dos direitos de outrem, para impedir a divulgação de informações confidenciais, ou para garantir a autoridade e a imparcialidade do poder judicial.

${ }^{99}$ Artigo $13^{\circ}$ - Direito a um recurso efetivo

Qualquer pessoa cujos direitos e liberdades reconhecidos na presente Convenção tiverem sido violados tem direito a recurso perante uma instância nacional, mesmo quando a violação tiver sido cometida por pessoas que atuem no exercício das suas funções oficiais.
} 
jurisprudência da $\mathrm{CIDH}$, que reconhece o direito à verdade como direito individual decorrente da garantia judicial.

Ainda no âmbito dos sistemas regionais, admite-se de forma incipiente o direito à verdade no Sistema Africano de proteção dos Direitos Humanos. Nesse sentido a Comissão Africana de Direitos Humanos e dos Povos, que possui atribuições mistas de interpretar a Carta Africana de Direitos Humanos e dos Povos, bem como receber demandas individuais, estabelece em seus Princípios e Diretrizes de Acesso à Justiça, de 2003, que o direito ao remédio efetivo não apenas inclui a reparação mas também o acesso a informações fatuais referentes às violações sofridas. ${ }^{100}$

Mais recentemente, com o estabelecimento efetivo do Tribunal Africano de Direitos Humanos e dos Povos em 2006, a questão do desaparecimento de pessoas também foi objeto de decisão no caso envolvendo a família do jornalista Norberto Zongo e o estado de Burkina Fasso, julgado em 28 de maio de 2014. No caso em apreço, Norberto Zongo, jornalista, foi assassinado em 1998, sem que fossem conduzidas as devidas investigações. ${ }^{101} \mathrm{O}$ TADH considerou que:

O Estado demandado, portanto, violou o artigo 7, bem como o artigo 9 (2) da Carta, lidas em conjunto com o artigo 66 (2) c) do Tratado revisado da CEDEAO [Comunidade Econômica dos Estados da África Ocidental], por não ter agido com a devida diligência na busca, na apuração e julgamento dos assassinos de Norbert Zongo e seus companheiros. Assim, Burkina Faso violou simultaneamente o artigo 1 da Carta, ao não tomar as medidas legais adequadas para garantir o respeito dos direitos dos requerentes nos termos do artigo 7 da Carta. ${ }^{102}$

${ }^{100}$ C. Right to an Effective Remedy:

(a) Everyone has the right to an effective remedy by competent national tribunals for acts violating the rights granted by the constitution, by law or by the Charter, notwithstanding that the acts were committed by persons in an official capacity.

(b) The right to an effective remedy includes:

1. access to justice;

2. reparation for the harm suffered;

3. access to the factual information concerning the violations.

COMISSÃO AFRICANA DE DIREITOS HUMANOS E DOS POVOS. Principles and Guidelines on the Right to a Fair Trial and Legal Assistance in Africa, 2003.

${ }^{101}$ TADHP. Case Abdoulaye Nikiema, Ernest Zongo, Blaise Ilboudo\& Burkinabe Human and Peoples' Rights Movement VS The Republic of Burkina Faso. Disponível em: <http://www.african-court.org > Acesso em: 01.12.2014.

102 "The Respondent State therefore violated Article 7 as well as Article 9 (2) of the Charter, read jointly with Article 66 (2) c) of the revised ECOWAS Treaty, because it failed to act with due diligence in seeking, trying and judging the assassins of Norbert Zongo and his companions. Hence, Burkina Faso simultaneously violated Article 1 of the Charter by failing to take appropriate legal measures to guarantee the respect of the rights of the Applicants pursuant to Article 7 of the Charter." 
A decisão do TADHP, portanto, assim como sua homologa no continente americano, reconhece o direito a ter acesso às informações acerca do assassinato, com base no direito de acesso à justiça e no direito de informação, assegurados, respectivamente nos $\operatorname{artigos} 7^{\circ}$ e $9^{\circ}$ da Carta Africana de Direitos Humanos e dos Povos. ${ }^{103}$

$\mathrm{O}$ conjunto de casos e a jurisprudência das diversas cortes, aliado às outras práticas dos estados permitem inferir que o direito à verdade passou a integrar o costume internacional. Assim, o reconhecimento do direito à verdade não se restringe às previsões expressas dos tratados internacionais, mas resultam de uma construção na órbita internacional, demonstrando-se a existência da opinio juris, ao se reconhecer a existência de uma obrigação.

Portanto, pode-se afirmar inclusive que o reconhecimento do direito à verdade em documentos internacionais reflete práticas que já vinham sendo desenvolvidas por alguns estados. Simultaneamente, as formulações do conteúdo do direito à verdade em resoluções e tratados, vêm também promover um avanço na implementação e concepção desse direito. Há, portanto, uma relação dialética entre a prática dos estados e os postulados teóricos do direito à verdade insculpidos no seio do soft law e do hard law internacionais.

As obrigações de direitos humanos possuem uma natureza especial e distinta das outras obrigações de direito internacional. Isso significa dizer que o consentimento dos estados por meio de tratados tem caráter declaratório de direitos humanos e não constitutivo. ${ }^{104}$ Tratam-se de obrigações erga omnes, pois dirigem-se à comunidade internacional como um todo. A respeito do caráter especial das normas de direitos humanos, pontua Mégret: “Embora a natureza especial das obrigações de direitos humanos

\footnotetext{
${ }^{103}$ Artigo $7^{\circ}$

1. Toda a pessoa tem direito a que a sua causa seja apreciada. Esse direito compreende:

a) $\mathrm{O}$ direito de recorrer aos tribunais nacionais competentes de qualquer ato que viole os direitos fundamentais que lhe são reconhecidos e garantidos pelas convenções, as leis, os regulamentos e os costumes em vigor;

b) $\mathrm{O}$ direito de presunção de inocência, até que a sua culpabilidade seja estabelecida por um tribunal competente;

c) O direito de defesa, incluindo o de ser assistido por um defensor de sua escolha;

d) O direito de ser julgado num prazo razoável por um tribunal imparcial.

2. Ninguém pode ser condenado por uma ação ou omissão que não constituía, no momento em que foi cometida, uma infracção legalmente punível. Nenhuma pena pode ser prescrita se não estiver prevista no momento em que a infracção foi cometida. A pena é pessoal e apenas pode atingir o delinquente.

Artigo $9^{\circ}$

1. Toda a pessoa tem direito à informação.

Toda a pessoa tem direito de exprimir e de difundir as suas opiniões no quadro das leis e dos regulamentos.

${ }^{104}$ MÉGRET, Frederic. Nature of Obligations. In: MOEKLI, Daniel, SHAH, Sangreeta, SIVAKUMARAN, Sandesh. International Human Rights. Oxford: Oxford University Press, 2010, p. 129.
} 
possa parecer, à primeira vista, ser uma mera construção doutrinária, é notável a extensão das consequências advindas dessa ideia."

Ademais, é possível também argumentar no sentido de que o direito à verdade é um princípio emergente do direito internacional, conforme pontua Mendez. ${ }^{106}$ A identificação dos princípios internacionais pode ser tão problemática quanto a do direito costumeiro. Entretanto, em linhas gerias, o que se pode afirmar, é que os princípios gerais do direito resultam de uma análise da prática dos principais sistemas legais. ${ }^{107}$

Em um dos trabalhos emblemáticos a respeito do direito à verdade, em 1997, Mendez descreveu haver uma tendência no direito internacional que aponta esse direito como princípio emergente. Desde, então o direito à verdade, passou a estar cada vez mais presente na agenda internacional e foi ainda objeto de inúmeras resoluções, sendo integrado também na Convenção Internacional para a Proteção de Todas as Pessoas contra Desaparecimentos Forçados. Houve, portanto, um impressionante desenvolvimento do tema. Assim, hoje, o que se vê é que o direito à verdade emergiu de forma definitiva como uma obrigação internacional e exigível.

Portanto, a obrigação de garantir o direito à verdade, pode ser reconhecida a partir de três perspectivas distintas: em razão das previsões insculpidas em tratados internacionais, enquanto direito costumeiro e na qualidade de princípio do direito internacional. Essas perspectivas não são excludentes, e conjuntamente oferecem a fundamentação necessária ao reconhecimento do direito à verdade, enquanto direito humano internacional.

A exigibilidade do direito à verdade implica um dever de respeito, proteção e promoção. Isso significa que, os estados têm um dever de não violação desse direito, na forma de prestação negativa, abstendo-se de divulgar informações falsas ou inverídicas. Deve ainda assegurar outras garantias para que não ocorram violações desse direito em seu território, por exemplo garantindo o direito ao recurso. Ao mesmo tempo, há também a obrigação de tomar providências a fim de garantir mecanismos de promoção do direito à verdade, por exemplo abrindo arquivos nacionais e instalando comissões da verdade quando necessário.

\footnotetext{
105 "Although the special nature of human rights obligations might at first appear to be a mere doctrinal construct, what is remarkable is the extent to which concrete consequences have flowen from this idea". Idem, p. 130, tradução livre.

106 MENDEZ, Juan E. Accountability for Past Abuses. In: Human Rights Quarterly. The Johns Hopkins University Press.19.2, 1997, p. 255-282

${ }^{107}$ BASSIOUNI, Cherif. A Functional Approach to General Principles of International Law. Spring, 1990.
} 


\subsection{Direito à verdade e a reordenação do papel da vítima}

Conforme apontado na seção anterior, o direito à verdade foi reconhecido inicialmente enquanto direito individual, no contexto de reparação das vítimas. Portanto, para análise do direito à verdade, é essencial compreender-se o papel exercido por elas, pois ocupam um lugar central nas discussões em torno do assunto.

Ao longo do curso da história, o papel das vítimas nos sistemas legais sofreu modificações, algumas vezes adquirindo centralidade e outras vezes sendo meramente secundário. Conforme aponta M. Cherif Bassiouni, os direitos das vítimas foram marginalizados com a centralização da administração da justiça nas mãos do estado. ${ }^{108} \mathrm{De}$ fato, durante o período em que a justiça tinha um caráter privatista, as vítimas assumiam um papel central, que entretanto, foi modificado quando o monopólio da força e da justiça passou a pertencer ao estado.

Juntamente com a própria ideia de estado, como detentor do monopólio do poder, nasceu o conceito de jurisdição estatal. Assim, a jurisdição encerra a ideia de substitutividade ao impor a vontade coercitiva do estado a partir do seu poder de imperium. ${ }^{109}$ Ao tornar-se público, o processo retirou a vítima do centro desse processo. Essa perda de espaço foi ainda mais contundente na esfera da responsabilidade penal, onde o próprio estado é ao mesmo tempo julgador e acusador. Com efeito, a partir da publicização do processo a vítima passou a ser mera expectante, não sendo-lhe facultado exercer qualquer tipo de influência sobrea decisão final ou no processo como um todo.

Só no final do século XIX é que as vítimas passaram a novamente ganhar espaço, a partir dos questionamentos a respeito da justiça retributiva. Surgiram, então, num movimento reflexo as teorias em favor de uma justiça com caráter restaurativo. A justiça restaurativa parte da visão de que há uma ruptura das relações entre a vítima e o autor no momento da agressão. Com isso, procura-se modificar essa dinâmica, reestabelecendo o balanço das relações, utilizando-se métodos de reconciliação e mediação.

\footnotetext{
${ }^{108}$ BASSIOUNI, M. Cherif. International Recognition of Victims Rights.In: Human Rights Law Review,62, 2006 , p. 208.

${ }^{109}$ Apesar dessa substituição da justiça privada pelo estado, em alguns países admiti-se que o julgamento seja feito por particulares através por exemplo do tribunal composto por representantes da sociedade. Essa tradição esta presente sobretudo nos países de common law, onde a competência dos tribunais do júri é alargada. Ainda sim permanece o caráter público do processo, que é conduzido pelo estado.
} 
A revalorização do papel da vítima é reflexo não apenas das novas teorias acerca da justiça e da solução de conflitos, mas também das grandes perdas humanas ocorridas nas duas grandes guerras, que chamam a atenção para a necessidade de garantir mecanismos de reparação. O julgamento de Eichmann é paradigmático do sentido de integrar as vítimas no processo. A partir de então a vítima passou a ter maior participação no julgamento de crimes graves. Nesse sentido, o próprio Estatuto de Roma, que instituiu o TPI, conta com inúmeras previsões que asseguram os interesses das vítimas no processo. Assim, a medida em que a responsabilização individual pelas violações de direitos humanos ganha força, passa-se também a atribuir maior peso ao papel das vítimas.

Portanto, o papel desempenhado pela vítima passa a ganhar destaque tanto no plano internacional, quanto no plano interno. No plano interno, as teorias mais modernas de direito penal e processual penal preocupam-se não apenas com o acusado e com a sanção a ele imposta, mas com os danos causados à vítima. No plano internacional, a vítima também passa a ter um papel proeminente na análise de crimes internacionais e contra a humanidade. Aponta o Secretário Geral da ONU que é necessário assegurar-se a centralidade das vítimas ao se projetarem os processo e mecanismos transicionais. ${ }^{110}$

Partindo-se desse ponto de vista, as comissões da verdade, enquanto mecanismos da justiça de transição, tornam-se um importante fórum de participação das vítimas. Essa participação ativa, simboliza por um lado uma espécie de catarse. Por outro lado, possibilita a reconstrução dos eventos, servindo como material essencial para o reconhecimento oficial das violações perpetradas.

Ao se ouvirem as diversas vozes, é possível traçar um panorama acerca do período vivido. Conforme apontado pelo ICTJ, ao se colocar foco sobre a violação de sofrida, permite-se maior objetividade política. Isso porque para ocupar a qualidade de vítima é imprescindível a experiência da violação e independente de qual lado estivesse ocupando durante o conflito. ${ }^{111}$ De maneira que a importância adquirida pelas vítimas nos processos transicionais caminha paralelamente ao reconhecimento do direito à verdade.

\footnotetext{
${ }^{110}$ A. Guiding Principles

6. Ensure the centrality of victims in the design and implementation of transitional justice processes and mechanisms. ONU. Secretary General. Guidance Note -United Nations Approach to Transitional Justice -2010.

111 "The focus on having suffered a human rights violation allows political objectivity, because a person is a victim if he or she experienced a violation regardless of what "side" he or she fought on in the conflict." ICTJ. Unfulfilled Expectations: Victims' Perceptions of Justice and Reparations in Timor-Leste.2010, p. 12. Disponível em: $\quad<$ http://www.ictj.org/sites/default/files/ICTJ-TimorLeste-Unfulfilled-Expectations-2010English.pdf $>$ Acesso em: 05.09.2014.
} 
Nesse sentido, as comissões da verdade exercem um papel essencial, na reordenação do papel exercido por elas, pois permite-lhes que sejam ouvidas e participem da narração histórica.

\subsection{Verdade, memória e o formação de identidades}

O exercício da memória é de fundamental importância para o estudo do direito à verdade. A partir do experiência individual e da retomada da trajetória das vítimas e familiares, forma-se uma memória coletiva, que reflete as diferentes forças existentes na sociedades que enfrentaram períodos de graves violações de direitos humanos.

$\mathrm{O}$ direito à verdade $\mathrm{e} \mathrm{o}$ direito à memória estão intimamente relacionados. $\mathrm{O}$ direito à memória implica a necessidade que se tem de refletir sobre o passado. ${ }^{112}$ É a garantia de que a verdade insculpida no passado será preservada e trazida à luz do debate público. O direito à verdade é, portanto, pressuposto necessário para o exercício do direito à memória, já que a reflexão sobre o passado só é possível - só é dotada de sentido quando feita a partir do conhecimento dos fatos. O direito à verdade, assim, diz respeito à revelação e elucidação dos fatos. A partir daí é possível a construção de uma memória coletiva. Assim, verdade e memória se entrelaçam em uma relação de sinergia. $\mathrm{O}$ direito à memória implica assegurar que os fatos e acontecimentos não sejam simplesmente esquecidos ou ocultados. Tal como o direito à verdade, também a memória pode ser retratada em termos individuais ou coletivos, sendo que ambas têm uma relação de influência recíproca. A memória individual é reflexo do testemunho subjetivo, é a lembrança pessoal. A memória coletiva, por seu turno, é a memória no plural, reflete a história de um povo, de uma comunidade, da conjunção das diferentes narrativas e vozes.

O direito à memória se consubstancia em diversos mecanismos de preservação das narrativas. Assim, a edição de relatos escritos, a preservação de espaços da memória, museus, registros midiáticos e outros recursos permitem que essa memória seja mantida. ${ }^{113}$

\footnotetext{
112 MENDONÇA, Andrey Borges de. O direito à memória: uma análise de seu conteúdo e efetividade no contexto brasileiro. 2009. Dissertação (Mestrado em Direito) - Departamento de Direito Público, Universidade Pablo de Olavide, Sevilha, 2009, p. 141.

${ }^{113} \mathrm{O}$ retrato e relevância desses mecanismos revela-se, por exemplo, na construção do Arquivo e Museu da Resistência de Timor Leste, instalado na capital Dili, e que tem como objetivo narrar a história da resistência às novas gerações. É não apenas um espaço de memória, mas também de construção da própria identidade timorense.
} 
Através de recursos variados é possível garantir o não esquecimento das experiências vividas individualmente e pela sociedade.

O esquecimento faz parte da natureza humana. Daí a necessidade de se estabelecerem mecanismos para afirmação da memória, pois ela pode facilmente ser apagada pelo esquecimento. Conforme assinala Paolo Rossi:

\begin{abstract}
No caso da historiografia, os processos de rememoração, que a constituem em sua essência mais profunda, parecem guiados por intenções precisas: remediar o esquecimento natural dos seres humanos, atarefados em seu cotidiano presente; conservar e permitir que seja utilizado um grande e rico patrimônio de traduções, instituições e ideias; criar um elo entre diferentes gerações dar lugar a formas de memoria coletiva que podem dizer respeito a pequenas ou grandes comunidades (os tifernantes, os escoceses ou os europeus) ou, até mesmo, a todo o gênero humano. $^{114}$
\end{abstract}

O esquecimento pode, por um lado, ocorrer de forma natural como reflexo da natureza humana que escolhe aquilo que deve ser lembrado. Essa seleção é inerente à própria constituição do indivíduo, que não sendo capaz de armazenar todas as informações e experiências vividas, se desfaz de partes dela, num processo de seleção natural. Esse processo diz respeito ao ser subjetivo e à memória individual. Por outro lado, o esquecimento também pode fazer parte de uma política do esquecimento, em uma tentativa de anular a memória coletiva e apagar as diversas vozes. Esquecimento, nesse aspecto, assemelha-se à ocultação. O esquecimento como escolha política, passa igualmente por uma seleção. Mas, o recorte que se faz leva em conta elementos de política de estado e a afirmação de uma ideologia.

Há, portanto, um abismo que separa o esquecimento natural do esquecimento imposto enquanto escolha política. O primeiro é reflexo da própria constituição humana e ocorre na esfera individual. O esquecimento enquanto escolha política é a ocultação deliberada dos acontecimentos. É o apagar dos fatos e por isso pode servir como instrumento perverso de manipulação, a favor de determinada ideologia. Com efeito, a seletividade dos fatos permite a dominação através da formação de uma falsa consciência, ocultando, assim, a realidade.

Além disso, a memória permite que se construa um senso de identidade, a partir da escolha dos fatos a serem valorizados e cultuados. As narrativas comuns levam a um

${ }^{114}$ ROSSI, Paolo. O passado, a memória, o esquecimento. São Paulo: UNESP, 2010, p. 206. 
senso de proximidade entre os indivíduos. Para dialogar com Zygmunt Bauman: "a ideia de "identidade" nasceu da crise do pertencimento e do esforço que esta desencadeou no sentido de transpor a brecha entre o "deve" e o "é" e erguer a realidade ao nível dos padrões estabelecidos pela ideia - recriar a realidade à semelhança da ideia". ${ }^{115}$ De maneira que a verdade e a memória, tornam-se eixos fundamentais na construção de identidades, ao permitir o reconhecimento de si no outro. Com efeito, a construção da identidade toma por base os elementos comuns, bem como as lutas históricas, transformando-os em uma narrativa integradora da sociedade.

A partir dessa visão é possível compreender porque a política de estado timorense busca a construção de sua identidade justamente a partir da luta da resistência. A valorização desse movimento imprime uma identidade comum a uma sociedade marcada pela segmentariedade. Em sentido oposto, a Indonésia absteve-se de um amplo debate público a respeito do período de dominação do território timorense e das violações de direito humanos ocorridas nas ilhas periféricas do arquipélago. Com efeito, as violações cometidas em Timor-Leste foram relegadas como um problema do novo país e não como uma mancha na história da sociedade indonésia. De maneira que a Indonésia adotou uma política do esquecimento, não apenas por não garantir a responsabilização penal dos mandantes, mas também por não incorporar os eventos sombrios de sua historia em sua própria narrativa e no debate publico.

A política do esquecimento é também o silenciar das experiências individuais, que compõem a memória coletiva. O direito à memória, portanto, não se traduz apenas na retomada de experiências coletivas, mas também de experiências individuais, que foram silenciadas, ou esquecidas em virtude da política do esquecimento. Há uma tensão permanente entre lembrar e esquecer. A partir dessa tensão emerge a necessidade de garantir mecanismos de preservação da história e da memória. O estudo do passado e dos acontecimento sempre foi objeto de estudo dos historiadores, entretanto ao se reconhecer importância da preservação da memória também no campo dos direitos humanos, essa memória transcende o campo da historiografia. O reconhecimento da memória e da verdade como um direito refletem o fato de que esse elementos são essenciais ao desenvolvimento do indivíduos enquanto seres humanos e da coletividade a que pertencem.

${ }^{115}$ BAUMAN, Zygmunt. Identidade. Rio de Janeiro: Zahar, 2005, p. 26. 
O reconhecimento do direito à memória não se esgota na narrativa estatal dos acontecimentos, na revelação dos fatos. Uma política de memória deve considerar os males e a violência infligidas às vítimas. ${ }^{116}$ Nesse sentido, engendra em si a narrativa da experiência individual, a narrativa da subjetividade, ao permitir que as próprias vítimas sejam ouvidas.

Mas, resta em aberto a indagação em torno de como essa memória e experiência individuais permitem a construção da memória e da identidade coletivas. Nesse diapasão, questiona-se de que maneira as experiências individuais, formam a base para a construção da memória coletiva. A esse respeito cumpre retomar o pensamento de Paul Ricoeur, para quem entre os dois polos da memória individual e da memória coletiva há a memória em relação ao próximo. Essa dimensão intermediária permite que as narrativas individuais, sejam trocadas com aqueles indivíduos mais próximos, como amigos e familiares. Assim, afirma que: "a ligação com os próximos corta transversal e eletivamente tanto as relações de filiação e do conjugalidade quando as relações sociais dispersas segundo suas formas múltiplas de pertencimento ou as ordens respectivas de grandeza." ${ }^{\prime 17}$ Portanto, é na relação com o próximo, que se estabelece o elo de ligação entre a memória individual e a memória coletiva.

A rememoração individual utiliza-se da linguagem, cuja estrutura é publica. A esse respeito, cumpre mais uma vez retomar o pensamento de Hannah Arendt, para quem o debate público deve ser caracterizado pela atribuição verdadeira de significados. Nesse sentido, a verdade factual, informa o debate público. Assim, a passagem da memória individual para a memória coletiva, é dotada de uma estrutura semelhante à passagem do direito à verdade enquanto direito individual, para o direito à verdade em sua dimensão coletiva. O estabelecimento de uma linguagem comum dos fatos, que permita o debate, passa pela rememoração de experiências individuais que tornam-se coletivas, a partir da relação estabelecida com os indivíduos próximos.

\footnotetext{
${ }^{116}$ GAUER, Ruth M. Chittó, SAAVEDRA, Giovani Agostini, GAUER, Gabriel J. Chittó. Memória, punição e justiça: uma abordagem interdisciplinar. Porto Alegre: Livraria do advogado, 2011, p. 46.

${ }^{117}$ RICOEUR, Paul. A memória, a história, o esquecimento. Campinas: Editora Unicamp, 2007, p. 141.
} 


\subsection{Direito à verdade e desenvolvimento democrático}

O direito à verdade, conforme apontado, deve também ser compreendido como o direito da sociedade em tomar conhecimento dos fatos e acontecimentos relacionados a atuação estatal. No entanto, o fato de ter-se tornado um tema central nos contextos transicionais, não reduz o direito de estabelecer a verdade a determinado período histórico ou em relação apenas a fatos específicos. O direito à verdade é pressuposto necessário aos estados democráticos, pois informa a relação entre estado e indivíduo. A esse respeito, a Comissão Interamericana de Direitos Humanos ressalta a intrínseca relação entre democracia, direitos humanos e verdade. ${ }^{118}$ Com efeito, trata-se de uma preocupação permanente no desenvolvimento democrático. Nesse sentido, mecanismos de transparência, como a abertura de arquivos públicos que se tornam instrumentos de garantia de acesso à informação por parte da população.

Para entender a relação entre verdade e democracia cumpre retomar o pensamento de Hannah Arendt, para quem a liberdade de participação se exerce na esfera pública através do debate e da ação. Não apenas a liberdade de participação exige essa interação pública, mas a própria liberdade de pensar, de acordo com Kant. Isso porque a razão humana é suscetível de falhas e por isso a atividade de pensar precisa ser examinada pelo controle público. ${ }^{119}$ Essas trocas na esfera pública podem ser traduzidas no que Kant chamou de mentalidade alargada (enlarged mentality). O diálogo com o outro permite considerar novas perspectivas. Pensar a partir de um novo ponto de vista torna-se imprescindível à própria liberdade de pensamento, sem a qual esta não é verdadeiramente livre.

O diálogo, a vida no plural deve ter como pano de fundo a verdade factual. Nas palavras de Celso Lafer: "a natureza dialógica da política propõe o problema da verdade factual, que informa a estrutura desse diálogo". ${ }^{120}$ Assim, todo sistema político depara-se com os dilemas em torno da verdade, da mentira e do segredo. Por isso, e discussão em torno do direito à verdade, não se limita a períodos transicionais, mas ocupa lugar central

\footnotetext{
118 CIDH. Derecho a la verdade en América, 2014, p. 17. Disponível em: $<$ http://www.oas.org/es/cidh/informes/pdfs/Derecho-Verdad-es.pdf $>$ Acesso em: 06.12.2014.

119 KANT, Immanuel. What is Enlightment.Apud: ARENDT, Hannah. Entre o passado e o futuro. São Paulo: Perspectiva, $11^{\text {a }}$ ed. 2011, p. 291-292 p.

${ }^{120}$ LAFER, Celso. Hannah Arendt pensamento, persuasão e poder. São Paulo: Paz e terra, 2003, p. 61.
} 
em toda formulação política. Tais preocupações podem tomar diferentes contornos e verificam-se em menor ou maior grau a depender do sistema político adotado.

Em uma democracia, o conhecimento da verdade factual revela-se essencial para que se possa informar os debates, garantindo-se a participação efetiva. A vita activa a que Hannah Arendt faz referência é justamente essa liberdade, em acepção grega: a liberdade de participar.

Nos sistemas democráticos, a soberania popular torna imprescindível a prestação de contas e informação aos cidadãos. Aos dirigentes estatais compete zelar pelos interesses da população - não como ocorre no paternalismo estatal - mas na qualidade de mandatários. O paternalismo estatal, caracterizado pela crença na ignorância dos cidadãos está presente nos sistemas autoritários, mas também pode emergir nas sociedades democráticas.

Aos mandatários exige-se a transparência na gestão do estado, uma vez que em última análise serão os cidadãos a chancelarem as escolhas de seus dirigentes. Os termos em que se dá essa relação entre representantes e representados são orientados pela liberdade de informação que circula na esfera pública. Quanto mais transparente essa atuação, maior o grau de participação popular e de controle da atuação estatal por parte da população. O sentido de responsabilização (accountability) repousa, portanto, na prestação de contas do estado. Com efeito, a responsabilização exige mecanismos de garantia e controle para que não haja um desvirtuamento das funções do estado.

A partir desse panorama, o direito à verdade revela-se em seu viés coletivo, de maneira a assegurar o acesso às informações a respeito da atuação estatal. Trata-se de um pressuposto necessário à própria ideia de representatividade. Nesse sentido, a medida dessa transparência e do acesso a informações estatais só atingiria o nível ideal em uma democracia perfeita. Entretanto, é possível identificar diferentes graus de transparência na atuação estatal, o que garante maior fiscalização e controle por parte da população. Portanto, quanto menos democrático um sistema político, tanto menos transparente será. Com efeito, um estado não democrático ou um estado autoritário não se sustentaria diante do controle popular. Para dialogar com Hannah Arendt:

Sem dúvida, os segredos de Estado sempre existiram; todo governo precisa classificar determinadas informações, subtraí-las da percepção pública, e os que revelam segredos autênticos foram sempre tratados como traidores. Não é com isto que me preocupo. Os fatos que tenho em 
mente são conhecidos publicamente, não obstante, o mesmo público que os conhece pode, com êxito, amiúde, espontaneamente, transformar em tabu sua discussão pública, tratando-os como se fossem aquilo que não são - isto é segredos. ${ }^{121}$

São utilizados recursos variados para alterar as verdades factuais, reescrevendo a história. Por isso, faz-se necessário compreender os mecanismos e aparatos utilizados na manipulação das verdades, que não são exclusivos de determinado sistema político. Com efeito, até mesmo uma democracia pode conter elementos do totalitarismo ou do autoritarismo.

Ainda que possam conter elementos comuns, a distinção dos regimes políticos é essencial. ${ }^{122}$ Tirania, ditadura, autoritarismo e totalitarismo não se confundem. A tirania caracteriza-se por ser um governo de um contra todos, em que não há qualquer tipo de limitação por leis. Assim, possui uma estrutura de forma igualitária, ou seja, o tirano permanece no topo da pirâmide de forma suspensa e todos os demais se encontram abaixo dele, sem distinção.

O autoritarismo repousa sobre uma legitimação externa e por isso está limitado por certas leis. Estruturalmente, o autoritarismo possui uma forma piramidal, com hierarquização de níveis, em que cada camada possui um grau de autoridade. Os regimes totalitários, por sua vez, buscam a dominação completa não apenas dos indivíduos, mas de todo o mundo. Caracterizam-se justamente por sua natureza amorfa. São alheios à estabilidade. Assemelham-se a uma casca de cebola, como suas diversas camadas encobertas entre si. Essa estrutura permite que se resista aos fatos reais. Por outro lado, pode haver hierarquias intermediárias, entretanto, trata-se de uma mera simulação, uma vez que a distribuição de poder não segue essa estrutura. ${ }^{123}$

Por seu turno, as ditaduras modernas caracterizam-se pela tomada do poder pelos militares e privação dos direitos políticos dos cidadãos. Podem também as ditaduras modernas resultar da captura do aparelho estatal por um determinado partido em

${ }^{121}$ ARENDT, Hannah. Entre o passado e o futuro. São Paulo: Perspectiva, 11 a ed. 2011, p. 293.

${ }^{122}$ Vide ARENDT, Hannah. Entre o passado e o futuro. São Paulo: Perspectiva, 11. ed. 2011, p. 133-138.

ARENDT, Hannah. As origens do totalitarismo. São Paulo: Companhia das Letras, 2012.

${ }^{123} \mathrm{O}$ regime totalitário também não se confunde com movimento totalitário. O regime totalitário só pode instalar-se onde houver uma população em número suficiente que permite, a eliminação de parte dessa população - algo que países com uma pequena população não poderiam se dar ao luxo. Os movimentos totalitários caracterizam-se pela organização das massas, diferentemente dos partidos, que baseiam-se no conceito de classes e de visão de negócios para sua organização. ARENDT, Hannah. As origens do totalitarismo. São Paulo: Companhia das Letras, 2012, p. 436-437. 
detrimento da oposição. ${ }^{124} \mathrm{~A}$ ditadura se assemelha ao totalitarismo, na medida em que impõe o fim da liberdade política. Entretanto, em uma ditadura, diferentemente de um regime totalitário, a vida privada ou a atividade política não são necessariamente afetadas. Os crimes cometidos por um regime ditatorial são orientados a seus opositores, enquanto que os crimes cometidos por sistemas totalitárias são abrangentes.

Sob esse prisma, é importante diferenciar as ditaduras que tipicamente se instalaram na segunda metade do século $\mathrm{XX}$ ao redor do mundo dos regimes totalitários, embora possam conter elementos destes. As ditaduras que se instalaram, sobretudo nos anos 60, 70 e 80, foram reflexo direto do fenômeno da bipolarização mundial entre países capitalistas e comunistas. ${ }^{125}$ Nesse contexto ocorreram grandes e repetidas violações de direitos humanos, na tentativa de neutralizar a atuação dos opositores políticos. Os opositores, ao terem seus direitos violados, eram enfraquecidos. Tornaram-se vítimas de crimes perpetrados por agentes estatais ou que se omitiram na punição dos violadores.

É importante considerar que as ditaduras e não apenas os regimes totalitários utilizam-se do artifício da mentira e do segredo para manutenção do poder. Hannah Arendt reconhece que "o verdadeiro poder começa onde o segredo começa". ${ }^{126}$ Por isso é que o direito à verdade é tão caro ao sistema democrático. Seu valor não está apenas na verdade factual como pano de fundo para o diálogo, para a ligação com o público, mas por se tratar de ferramenta de proteção contra arbitrariedades estatais.

$\mathrm{Na}$ medida em que atua como instrumento de proteção do indivíduo e da sociedade contra abusos do poder estatal, a verdade deve ser estabelecida, mesmo que tardiamente. Ainda que o direito à verdade tenha sido negado durante períodos de governos não democráticos, o dever de retrospecção, de recuperação da verdade permanece. Isso pode ser feito através de inúmeros mecanismos, como processos judiciais e comissões da

\footnotetext{
${ }^{124}$ As ditaduras podem ser ditaduras modernas ou ditaduras, na acepção romana. As ditaduras romanas caracterizavam-se por situações emergenciais de governo. Eram portanto, limitadas espacialmente e temporalmente. Inseriam-se no contexto de um governo constitucional. ARENDT, Hannah. Responsabilidade e julgamento. São Paulo: Companhia das Letras, 2004, p.95.

${ }^{125}$ Nesse período Timor-Leste sofreu a ocupação pela Indonésia, sob o comando do ditador Suharto, em 07 de dezembro de 1975. Suharto - o segundo presidente da Indonésia, após a independência do país - ascendeu ao poder em 1967, logo após um golpe militar e permaneceu no poder até 1998, quando resignou o comando do país. Timor-Leste, que acabara de declarar unilateralmente sua independência, nove dias antes, representava a ameaça do comunismo na região. Com efeito, no mesmo ano em que a Fretilin declarou unilateralmente a independência de Timor-Leste, o Vietnã comemorava a vitória do comunismo na guerra que travará com a porção sul, que era apoiada pelos Estados Unidos. Nesse contexto, Estados Unidos e Austrália não opuseram qualquer tipo de obstáculo à ocupação da Indonésia, pois a ameaça comunista era iminente.

${ }^{126}$ ARENDT, Hannah. As origens do totalitarismo.São Paulo: Companhia das Letras, 2012, p. 542.
} 
verdade. O estabelecimento da verdade a posteriori, tem uma finalidade dupla. Ao mesmo tempo em que se volta para o passado, tem função pedagógica, servindo como um esclarecimento para as gerações futuras. Daí a importância em se apurarem violações do passado e estabelecer a verdade. Conforme lição de Hannah Arendt "compreender não significa negar o ultrajante....significa antes examinar e suportar conscientemente o fardo que os acontecimentos colocaram sobre nós...significa em suma, encarar a realidade". ${ }^{27}$

O direito à verdade atua, portanto, como mola propulsora para o desenvolvimento humano e da sociedade. Exerce assim um papel educativo, que reside no fato de revelar aquilo que não mais pode tornar a ser. Assinala Paul Ricoeur: "as coisas passadas são abolidas, mas ninguém pode fazer com que não tenham sido". ${ }^{128}$ Assim, não se pode apagar o passado, mas é possível estabelecer novos paradigmas para o futuro. $\mathrm{O}$ estabelecimento a verdade factual pode atuar como limitador das ações humanas futuras, passando a pertencer ao repertório de valores da sociedade.

Através da atividade comunicativa, cuja fundamentação deve ter por base os fatos, as experiências são repassadas e passam a fazer parte do patrimônio comum. ${ }^{129}$ Referida asserção leva ao reconhecimento da fundamentalidade do direito à verdade, em sua dimensão coletiva, para o desenvolvimento democrático.

\subsection{O dilema entre o direito à verdade e a razão de estado}

Segundo Hannah Arendt, os estado autoritários estruturam-se na forma de cebola, de maneira a manter o segredo no centro, protegido contra os choques exteriores. $\mathrm{O}$ segredo, entretanto, não é um artifício que caracteriza exclusivamente os estados totalitários. Com efeito, o recurso ao segredo permeia todas as formas de organização política em maior ou menor grau, sob a égide do discurso da razão de estado.

Assim, estados autoritários e até mesmo estados democráticos, também se utilizam amplamente desse recurso. A história é farta em exemplos nesse sentido. $\mathrm{O}$ caso de Eduard Snowden é paradigmático ao sinalizar que mesmo em estados democráticos os

\footnotetext{
${ }^{127}$ Idem, p. 21.

${ }^{128}$ RICOEUR, Paul. A memória, a história, o esquecimento. Campinas: Editora Unicamp, 2007. p. 294.

${ }^{129}$ Fukuyama assinala "qualquer grupo social que tenha desenvolvido uma capacidade cognitiva ligeiramente melhor de usar e interpretar a linguagem e, portanto, para detectar a mentira, conseguiu vantagens sobre os concorrentes". FUKUYAMA, Francis. The Origins of Political Order.London: Profile Books, 2012, p.35.
} 
dilemas entre a verdade e o segredo são inquietantes. $O$ ex-agente de inteligência americana trouxe a público o monitoramento de todo o fluxo de informações a nível global, realizado pelos Estados Unidos, contando com o apoio de outros países. Revela assim duas facetas do dilema em torno do direito à informação: o fato de as mensagens estarem sendo monitoradas de forma sigilosa, sem qualquer mecanismo de controle do poder estatal e o direito à privacidade dos indivíduos, países e entidades monitorados.

Outro exemplo do dilema entre verdade e segredo consiste na não abertura dos arquivos referentes ao período da ditadura militar no Brasil para as investigações da Comissão Nacional da Verdade. A obstacularização do acesso aos arquivos coloca sérios entraves ao cumprimento das obrigações de direitos humanos por parte do estado. $\mathrm{O}$ fenômeno de manutenção do sigilo dos documentos militares revela-se como uma problemática frequente. A mesma dificuldade foi enfrentada pela CAVR em Timor-Leste, a quem foi negado o aceso aos arquivos dos militares indonésios. Solução diametralmente oposta foi adotada na Alemanha, onde todos os arquivos dos antigos órgãos de repressão e investigação foram abertos ao público.

De maneira que mesmo nos estados democráticos, o segredo é utilizado como ferramenta de política de estado.Com efeito, há certas esferas de decisão que para serem tomadas, ou para serem efetivas, primeiro devem passar por um processo de deliberação de alguma forma excludente do conhecimento de toda a população. Entretanto, tais temas devem ser reduzidos somente ao estritamente necessário. Nesse sentido, não se pode presumir a necessidade de sigilo, devendo ela ser muito bem fundamentada, sob o risco de tornar-se abusivo. A esse respeito assinala Sisella Bok:

\footnotetext{
[Referida] tendência de ampliação do segredo administrativo aumenta as chances de abuso, sobretudo entre os funcionários com um elevado senso de encargo e de estar acima das considerações morais comuns. Quando um governo desenvolve poderes de polícia secreta ou de controle sobre a censura, os riscos são ainda maiores. O sigilo pode, então, tornar-se um fim em si mesmo, criando mudanças sutis naqueles que o exercem, na forma como eles vêm a si mesmos, e na sua propensão em manipular e coagir a fim de manter o segredo e, assim, proteger-se. Ao utilizarem o véu do segredo para cometer os crimes, buscam por uma proteção cada vez mais abrangente. ${ }^{130}$
}

\footnotetext{
130 "Such a tendency for administrative secrecy to spread increases the chances of abuse, especially among officials with a strong sense of mission and of being above ordinary moral considerations. When a government develops secret police powers or control over censorship, the risks are even greater. Secrecy can then become an end in itself, creating subtle changes in those who exercise it, in how they see themselves, and in their willingness to manipulate and coerce in order to uphold secrecy and thus shield themselves. To the extent that they have used the cover of secrecy to commit crimes, they reach out for ever greater
} 
Ainda que em algumas situações o segredo de estado seja imprescindível à manutenção da própria soberania, é pertinente indagar a respeito dos limites desse segredo. Conforme apontado, não se pode presumir a legitimidade da manutenção do sigilo. Ao contrário, em princípio todas as decisões tomadas em nome do estado devem ser públicas para que se submetam ao escrutínio da população. Especialmente quando se tratam de violações de direitos humanos, a manutenção do sigilo mostra-se inadmissível, porque incompatível com as obrigações e funções do próprio estado de assegurar tais direitos.

Com efeito, a segurança e a manutenção da soberania do estado não são suficientes para justificar o segredo em relação a violações de direitos humanos. É certo que em casos de estado de sítio e emergência revele-se necessária a restrição parcial de determinadas liberdades fundamentais. Entretanto, tais situações não justificam por si só a violação massiva de direitos humanos, nem tampouco sua ocultação.

A dicotomia entre segredo e verdade coloca questões morais às escolhas políticas, assim como o dilema entre verdade e mentira. O segredo não se confunde com a mentira, pois erige barreiras, diferenciando o grupo seleto que possui acesso à informação. Por outro lado, a mentira se caracteriza pelo desvirtuamento deliberado da verdade. A mentira, assim como o segredo, também é utilizada como forma de dominação e de manutenção do poder. A respeito da utilização da mentira assinala Celso Lafer:

\begin{abstract}
Ora, a mentira, nos sistemas políticos tradicionais, era limitada porque, sendo limitada a participação política, ela não implicava normalmente em auto-ilusão. Entretanto, no mundo contemporâneo, estas distinções tendem a desaparecer porque a novas técnicas de comunicação somadas à incorporação das massas nos sistema políticos levaram a novas modalidades de manipulação da opinião ${ }^{131}$
\end{abstract}

É certo que os novos meios de comunicação inauguram uma nova fase na relação entre estado e indivíduos, colocando novos métodos de manipulação das verdades, mas também abrindo caminho para o maior acesso à informação. De maneira que a internet, e a televisão ao mesmo tempo em que podem servir como instrumento de ilusão que favorecem ideologias e elementos do autoritarismo, podem também servir em favor de uma maior fiscalização da atuação estatal.

protection". BOK, Sissela. Secrets - On the Ethics of Concealment and Revelation.New York: Vintage Books, 1989. p. 177, tradução livre.

${ }^{131}$ LAFER, Celso. Hannah Arendt-Pensamento, persuasão e poder. São Paulo: Paz e Terra. 2003, p. 61. 
Assim, os limites a serem traçados entre a publicização de informações, a preservação da privacidade e os interesses de estado colocam questões éticas em torno das quais é necessário refletir. Mas, o que é certo é que antagonismo entre direito à verdade e a mentira ou direito à verdade e segredo, fundados na razão de estado, não são suficientes para justificar o mascaramento de violações de direitos humanos.

Não obstante, a realidade revela que frequentemente a escala de valores entre direitos humanos e razão de estado é invertida. Diante de tal fenômeno, o fortalecimento de instancias de fiscalização, de mobilização da sociedade civil e de mecanismos internacionais de proteção dos direitos humanos são essenciais para assegurar o respeito aos direitos humanos por parte dos estados e o amplo acesso à informação. 


\section{A COMISSÃO DE ACOLHIMENTO, VERDADE E RECONCILIAÇÃO DE TIMOR-LESTE (2002-2005)}

A questão da implementação - não apenas dos direitos humanos - é uma discussão permanente e central para o direito. Por isso, o estudo jurídico que se limita à discussão teórica torna-se estéril, no sentido de não abranger os próprios fins do direito. Isso porque o direito é, na realidade, um meio de tutela do indivíduo e da sociedade. Assim, um estudo compreensivo necessita estar de acordo com as próprias finalidades a que o direito se propõe. Para Bobbio, a discussão em torno dos meios para proteção dos direitos reconhecidos é fundamental não apenas em termos de efetivação, mas para a própria compreensão desses direitos enunciados. ${ }^{132}$

Portanto, a seguir será analisado como o direito à verdade pode ser implementado, tomando-se como exemplo os trabalhos da CAVR. O estudo do direito à verdade faz com que seja imprescindível uma análise pragmática pois: "outro fator de grande impacto sobre o desenvolvimento do direito à verdade foi o estabelecimento de "Comissões da Verdade" ou de outros mecanismos semelhantes no rescaldo do conflito ou de um governo autoritário que tenha levado a violações massivas de direitos humanos". ${ }^{133}$ Assim, o próprio conceito de direito à verdade e seu conteúdo também são influenciados pelo conjunto dos trabalhos desenvolvidos por essas comissões.

A CAVR foi instalada com a finalidade de apurar as violações de direitos humanos ocorridas durante a ocupação que Timor-Leste sofreu por parte da Indonésia, abrangendo também o período imediatamente antes da invasão, bem como o contexto do referendo popular que votou a favor da independência do país. Foi criada durante a missão de operação de paz da ONU, a quem incumbiu a administração do território logo após a retirada da Indonésia. O embrião da CAVR, surgiu no primeiro congresso nacional do CNRT (Congresso Nacional de Reconstrução de Timor-Leste) realizado em 2000. Atualmente o CNRT é um dos partidos políticos com maior expressão no país, cujo o principal expoente foi o líder da resistência Xanana Gusmão. Mas, ao ser criado em abril de 1998 o CNRT caracterizava-se como um movimento de unidade nacional que liderou a

\footnotetext{
${ }^{132}$ BOBBIO, Norberto. A era dos direitos. Rio de Janeiro: Elsevier, 2004, p.44.

${ }^{133}$ ONU. Commission on Human Rights. Report of the Office of the United Nations High Commissioner for Human Rights - Study on the Right to the Truth. E/CN.4/2006/91, de 08.02.2006.
} 
resistência, abrangendo diversos grupos e ideologias políticas. ${ }^{134}$ A ideia de estabelecer uma comissão da verdade para Timor-Leste levou à criação de uma Comissão Diretiva, apoiada por ONGs de direitos humanos, por associações, pela Igreja Católica, pela ACNUR e pela UNTAET. Essa comissão diretiva, então organizou reuniões, entre setembro de 2000 e janeiro de 2001, com diversos segmentos da sociedade em todo o país para ouvir opiniões. A partir da proposta dessa comissão, foi promulgado o regulamento UNTAET 10, em 13 de julho de 2001, criando a CAVR e recepcionado pela nova Constituição de Timor-Leste, de maio de 2002. ${ }^{135}$

Coube à CAVR investigar as violações de direitos humanos, estabelecer um registro histórico fatual, promover processos de reconciliação comunitária e realizar recomendações, de forma a assegurar a promoção e o respeito aos direitos humanos, bem como as reformas institucionais necessárias. A apresentação do relatório Chega! constituído por 2800 páginas, em 2005, representou um marco paradigmático no processo de reestruturação e reconciliação do país. Os trabalhos e os resultados apresentados pela CAVR são considerados, ao lado do trabalho da Comissão da Verdade para África do Sul, como referência de sucesso no estudo da justiça de transição. No entanto, conforme será apontado, contingências políticas e sociais impuseram inúmeros desafios aos trabalhos, que devem ser devidamente consideradas.

Ao lado da CAVR, outros mecanismos de justiça de transição foram adotados em Timor-Leste. De maneira que é preciso ainda considerar a interação da CAVR com os demais elementos que compuseram a política transicional, como os Painéis Especiais e a Comissão para Verdade e Amizade (CTF), entre Timor-Leste e Indonésia.

\footnotetext{
${ }^{134}$ O CNRT veio substituir o Conselho Regional Maubere (CRM), que já se propunha a estabelecer um movimento de unidade nacional. O CRM foi instalado em 1987 e por sua vez substituiu o Conselho Revolucionário de Resistencia Nacional (CRRN), que foi estabelecido em 1981. A criação desse conselhos se deve à perda de espaço que sofreu a resistência em final dos anos 70. Desde a anexação pela Indonésia em 1975 até 1979 , a resistência contava ainda com uma forte participação civil, caracterizada por uma guerra popular prolongada, contando om zonas libertadas. Durante esse período, o partido político da FReTiLIn, que havia declarada a independência unilateral em 1975, esteve a frente da organização do apoio dos civis. Cabia às Falintil, enquanto braço armado cuidar da segurança. Mas, com a perda de espaço e a consolidação do poder da Indonésia a partir da década de 80 foi necessário um rearranjo organizacional da resistência, que não podia mais contar com a base de apoio das zonas libertadas. Com isso a luta armada e a frente diplomática cresceram em importância. Com a parda do espaço civil, as Falintil, enquanto braço armado, passaram a liderar a resistência, já que era o único braço que efetivamente ainda funcionava. Diante da perda das zonas libertadas, que eram organizadas pela FReTiLIn, esta restou enfraquecida. Mas, a necessidade de ter um fórum politico de liderança da resistência e não apenas uma frente armada levara à criação do CRRN e dos conselhos que lhe sucederam (CRM e CNRT).

${ }^{135}$ A sede da CAVR e o local onde atualmente se encontra o pós-secretariado é revestida de simbolismo, localizada no antigo presídio de Balidi. Construído pelos portugueses, foi utilizado pela FReTiLIn como presidio politico, onde eram mantidos os membros da UDT e Apodeti. Posteriormente, a Indonésia utilizou o mesmo local como prisão, que foi danificada na onda de violência de 1999.
} 
Antes de se passar à análise dos trabalhos da CAVR e sua relação com o direito à verdade, é imprescindível compreender o contexto de Timor-Leste. Portanto, a seguir serão abordados os principais elementos históricos e sociais que influenciaram a criação e a atuação da CAVR. Muitos dos eventos a seguir descritos foram objeto de estudo da comissão, cujo mandato abrangia os fatos ocorridos entre 05 de abril de 1974 e 25 de outubro de 1999. Conforme será analisado a seguir, Timor-Leste é marcado por um histórico de invasões estrangeiras, resistência e uma estrutura social segmentada e centrada nos laços comunitários e familiares.

\subsection{Os antecedentes históricos}

Timor-Leste, está situado entre o Sudeste asiático, a Austrália e as Ilhas Melanésias. Foi colonizado pelos portugueses e posteriormente invadido pela Indonésia, em 1975. Marcado por traumas da violência, o país restaurou sua independência em 2002.

Apesar de não haver muitos registros a respeito da fase anterior à chegada dos portugueses, sabe-se que Timor-Leste era divido em reinos, dirigidos pelos liurais (reis). Há uma mistificação em torno do povo maubere (timorense) do período pré-colonial. A necessidade de construção de uma identidade nacional, a partir da retirada indonésia, levou a um movimento de retomada da cultura originária timorense.

Os primeiros portugueses chegaram à ilha em 1512, pouco antes da chegada dos holandeses à porção oeste no ano de 1595. De maneira que a ilha de Timor dividia-se em dois domínios - o domínio português e o domínio holandês - atual região de Kupang, que pertence à Indonésia. ${ }^{136} \mathrm{~A}$ porção portuguesa foi declarada colônia em 1769. A presença portuguesa caracterizou-se pelas alianças com os liurais. ${ }^{137}$ A relação entre Timor-Leste e Portugal pouco se assemelhava à relação estabelecida com suas demais colônias na África e no Brasil. Pode-se dizer que em Timor-Leste a presença portuguesa era diminuta, não apenas pela distância do continente europeu, mas também pela aparente ausência de recursos naturais presentes na ilha, com exceção do sândalo. Além da colonização

\footnotetext{
${ }^{136}$ Importante registrar que, já durante o período colonial, havia um enclave na região Oeste, que pertencia ao domínio português, e posteriormente passou a ser o distrito de Oecusse, parte integrante de Timor-Leste.

${ }^{137}$ Há registros de que se tratavam de relações bastante conflituosas. Vide CUNHA, João Solano Carneiro de. A questão do Timor-Leste: origens e evolução. Brasília: do Instituto Rio Branco, 2001. Disponível em: $<$ http://www.funag.gov.br/biblioteca/index.php?option=com_docman\&task=doc_details\&gid=390\&Itemid= 41> Acesso em: 07.032012.
} 
portuguesa, deve-se ressaltar a presença de comerciantes chineses, que tiveram um importante papel na história de Timor-Leste.

No decorrer da $2^{\mathrm{a}}$ Guerra Mundial o domínio de Portugal - que permaneceu neutro ao conflito - restou enfraquecido. Em 1941 - devido à proximidade com a Austrália, Timor-Leste foi tomado por forças australianas e holandesas, diante do temor de uma possível invasão japonesa. Esse temor concretizou-se e em seguida o território foi invadido pelo Japão, deixando milhares de timorenses mortos. A invasão japonesa levou a uma espécie de dívida moral do país para com Timor-Leste, presente ainda hoje na condução da política externa e das relações bilaterais. ${ }^{138}$

O fim da $2^{\mathrm{a}}$ Guerra Mundial assinalou a volta da região às mãos da administração portuguesa. Simultaneamente, inaugurou-se uma nova fase na ordem mundial em que o modelo colonial passou a sofrer veemente oposição, tendo a ONU um importante papel nesse novo contexto. Com a entrada de Portugal para as Nações Unidas iniciou-se certa pressão para garantir autonomia dos territórios coloniais.Com a resolução A/RES/XV/1541, da Assembleia Geral da ONU, de 15 de dezembro de 1960, que afirmou o direito à autodeterminação dos povos e a garantia de descolonização, Timor-Leste foi considerado como território sem governo. ${ }^{139}$ De acordo com a resolução, essa condição só cessaria mediante a emergência de um novo estado soberano, a associação livre a um estado independente ou a integração a um estado independente (princípio VI).

Ainda que o cenário internacional apontasse no sentido inevitável da descolonização, Portugal manteve durante longos anos sua política de dominação sobre suas colônias. Uma efetiva mudança na posição de Portugal só ocorreu após a Revolução dos Cravos, em abril de 1974. O governo provisório que se constituiu logo após a revolução tratou de reconhecer a autodeterminação dos povos e passou a abordar a questão sob o aspecto político e não mais militar. Para tanto foi necessária a edição de uma nova lei constitucional que autorizasse a interpretação em favor da autodeterminação e o reconhecimento das independências nos territórios ultramarinos.

A partir dessa nova fase - com a autorização de Portugal para criação de partidos políticos - nasceram três principais partidos em Timor-Leste: (1) UDT; (2) ASDT e (3) AITI. A União Democrática Timorense (UDT) defendia uma fase de transição, em ${ }^{138}$ COTTON, James. East Timor, Australia and Regional Order, Politics. London School of Economics, 2004.

${ }^{139}$ ONU. AG. Resolução 1541 (XV), de 15.12.1960. 
cooperação com Portugal antes da efetiva independência. Já a Associação SocialDemocrática Timorense (ASDT) - antecessora do atual partido FReTLIn (Frente Revolucionária para Timor-Leste Independente) - defendia ideais anti-colonialista. Por sua vez, a Associação para a Integração de Timor na Indonésia (AITI) - antecessora da (APODETI) - propunha que Timor-Leste fosse integrado à Indonésia. É importante compreender a formação de referidas forças políticas, pois a oposição entre elas foi um fator decisivo no escalonamento do conflito interno, que antecedeu a invasão pelo país vizinho. Em 7 de dezembro de 1975 - nove dias após a declaração unilateral de independência feita pela FReTLIn, a Indonésia invadiu Timor-Leste.

A invasão pela Indonésia levou ao abandono do território pelos portugueses, dando início a 24 anos de dominação, marcada pela supressão da cultura timorense e pela proibição de utilização do idioma português. Desde 1967, a Indonésia esteve sob o regime militar, comandado pelo General Suharto, que governou o país por mais de trinta anos. Somente resignou em 21 de maio de 1998 em meio à crise econômica e aos conflitos étnicos e religiosos por todo o país.

Tão logo a FReTLIn declarou unilateralmente a independência, os outros partidos políticos assinaram o que ficou conhecido como a Declaração de Balibó, em que afirmavam a integração de Timor-Leste à Indonésia, conforme consta no relatório final da CAVR: “A Indonésia procurou legitimar a sua anexação de Timor-Leste. Uma Assembleia Representativa Popular, composta por timorenses escolhidos a dedo, reuniu-se em Maio de 1976, invocando a Declaração de Balibó, aprovou por unanimidade uma petição que solicitava a integração". ${ }^{140}$ Em julho de 1976 o Parlamento da Indonésia aprovou uma lei que reconheceu Timor-Leste como província do país, procurando assim imprimir maior legitimidade à invasão.

A dominação indonésia em Timor-Leste pode ser dividida em três fases. De acordo com o relatório Chega! a primeira fase, de 1976 a 1979 ficou conhecido como o "período de operações militares indonésias em larga escala e de resistência". A segunda fase, de 1980 a 1984, foi de consolidação militar da Indonésia e reconstrução da resistência. De 1985 a 1998 ocorreu a terceira fase, chamadade normalização. Por fim,

140 CAVR. Relatório Chega! Introdução, 2005, p. 9. Disponível em: <http://www.cavrtimorleste.org/po/Relatorio\%20Chega!.htm> Acesso em 07.03.2012. 
houve ainda o período próximo ao referendo em 1999, de extrema violência e marcado pela doutrina da terra arrasada. ${ }^{141}$

Apesar de Timor-Leste estar de facto sujeito ao governo indonésio, do ponto de vista do direito internacional, a condição de Timor-Leste enquanto território sem governo só cessou em 2002, quando finalmente o país tornou-se independente. Isso porque, a comunidade internacional não reconheceu a anexação realizada pela Indonésia e nem a independência proclamada pelos timorenses em 1975. Daí porque, Portugal sempre esteve à frente das negociações em prol da independência do país. Portugal não só tinha interesses políticos e econômicos na independência de Timor-Leste, mas tinha ainda e apesar de tudo, obrigações e responsabilidades sobre o território.

Em 1999 uma série de tratados entre Portugal e Indonésia foram assinados, com a intermediação da ONU. Estabeleceu-se que seria feita uma consulta pública aos timorenses a respeito da situação do Timor-Leste: foram indagados se desejavam ser parte de território autônomo da Indonésia ou se votavam pela independência. Em 30 de agosto de 1999 os timorenses decidiram por uma maioria esmagadora que desejavam a independência. À afirmação da vontade de independência seguiram-se cenas de terror generalizado por parte das forças pro Indonésia. O mundo assistiu em choque a doutrina de terra arrasada adotada pelas forças do país vizinho em relação a Timor-Leste, que viu todo o seu território em chamas. A cobertura midiática - possibilitada em grande parte pela presença de jornalistas que se encontravam lá para relatar as votações - fez com que o mundo inteiro visse as cenas de horror perpetradas no ano de 1999.

A partir desse momento, a ONU estabeleceu Administração de Transição para o Timor-Leste (United Nations Transitional Administration for East Timor - UNTAET), cujo mandato iniciou-se em 25 de outubro de 1999 e estendeu-se até 20 de maio de 2002.A missão da UNTAET tinha por objetivo, entre outros, a manutenção da ordem e segurança, bem como o estabelecimento de uma administração efetiva. Chefiada pelo brasileiro Sérgio Vieira de Mello, a UNTAET além de nomear os integrantes do poder judiciário, detinha poderes administrativos e normativos.

Foi durante o mandato da UNTAET, encarregada de desenvolver uma política transicional efetiva, que se criou em 13 de julho de 2001 a Comissão para Acolhimento, Verdade e Reconciliação (CAVR), com objetivo de averiguar as violações aos direitos

${ }^{141}$ Idem. CAVR. 
humanos cometidas entre abril de 1974 - quando Portugal deu início ao processo de autonomia e autorizou a criação dos partidos políticos - e Outubro de 1999 - período de acirramentos dos conflitos no território em razão do referendo. ${ }^{142} \mathrm{~A}$ instalação de comissões da verdade, já fazia parte de uma agenda política do ONU no contexto transicional, sobretudo guiadas pelo exemplo da comissão da verdade instalada na África do Sul.

Com a aproximação do fim do mandato da UNTAET e diante das fragilidades institucionais, percebeu-se a necessidade de nova missão para Timor-Leste. Instalou-se a Missão de Suporte a Timor-Leste (United Nations Mission of Support to East Timor UNMISET), que durou três anos - de 20 de maio de 2002 a 20 de maio de 2005. Com o fim da UNMISET, instalou-se um escritório das Nações Unidas, denominado de UNOTIL (United Nations Office for Timor-Leste), que perdurou por pouco tempo: de 20 de maio de 2005 a 25 de agosto de 2006. A instalação do escritório tinha por objetivo possibilitar a paulatina autonomia efetiva dos timorenses e de suas instituições. Com a saída das forças de manutenção de paz, tinha-se a ideia de que ficassem no país apenas alguns funcionários da ONU a fim de observar e auxiliar nesse novo passo da independência timorense.

Entretanto, nas eleições de agosto de 2006 alastrou-se violência generalizada, fruto de descontentamentos da população e de rivalidades territoriais. A situação levou a um grande número de refugiados. A crise de 2006 é frequentemente apontada como um sintoma do insucesso da política transicional adotada em Timor-Leste, que não teria sido eficaz em estabelecer os fundamentos da coesão nacional.

Diante da nova onda de violência, o próprio país solicitou o auxílio das forças da ONU para conter a situação, que já se mostrava dramática. Foi, então, enviada uma força internacional de estabilização, sobretudo com tropas australianas e neozelandesas. Instalou-se então a UNMIT (United Nations Mission to Timor-Leste), cujo mandato iniciou-se em 25 de agosto de 2006 e se encerrou em 31 de dezembro de $2012 .{ }^{143}$ Desde a crise de 2006, não há registros de incidentes de violência generalizada em larga escala, apesar permanência de alguns conflitos pontuais.

Assim, o ano de 2012 teve significado histórico de extrema relevância, ao encerar as operações de paz no país, marcando a superação do pós-conflito. A partir de então os 142 UNTAET. REG/2001/10. Disponível em: <http://www.unmit.org/legal/UNTAET-
Law/Regulations\%20Portuguese/Reg2001-10por.pdf>Acesso em: 07.03.2012.
ONU. Conselho de Segurança. Resolução 1969, de 24.02.2011. Disponível el em
<http://www.un.org/ga/search/view_doc.asp?symbol=S/RES/1969(2011)> Acesso em 07.03. 2012. 
esforços passaram a ser reorientados, expondo novos desafios, como o desenvolvimento e a consolidação das instituições democráticas do país. Nesse sentido a CAVR teve um importante papel na reformulação das instituições, por se tratar de um espaço democrático, que permitiu a participação popular.

\subsection{Aspectos sociais e culturais}

O trabalho da CAVR não pode ser compreendido sem que se considerem as peculiaridades da sociedade timorense. Portanto, é necessário analisar não apenas o contexto histórico no qual foi criada a CAVR, mas também a organização social prevalecente no país, que foi determinante para o alcance comunitário e o apelo social que teve a comissão.

A efetividade com que a CAVR conseguiu estabelecer laços de comunicação e interesse com a população se deve em grande medida ao fato de que o conflito penetrou no seio da sociedade civil, envolvendo toda a população. Portanto, o trabalho da CAVR no contexto do pós-conflito de alguma forma tocava diretamente em interesses da maior parte da população. O grande número de mortes e desparecimentos fez com que todos se relacionassem ao conflito e, portanto, se interessem pelos trabalhos da comissão.

Outro importante fator no envolvimento da sociedade nos trabalhos da CAVR diz respeito à própria estrutura social, que se caracteriza como segmentaria. Isso faz com que cada indivíduo timorense identifique-se em um primeiro plano com sua vila (suco) e sua família, sendo que a qualidade de timorense, muitas vezes vem em um segundo plano. Ciente desse senso de pertencimento do indivíduo à sua comunidade, a CAVR incorporou esses aspectos formadores da cultura local, fazendo com que operassem a seu favor. Assim, estabeleceu-se uma ponte para o diálogo com os indivíduos através das comunidades a partir da valorização de processo locais e de formas tradicionais de justiça.

Devido a essa característica segmentada da sociedade timorense, a noção de estado ainda oferece desafios à compreensão, pois prevalece no país a organização a nível local de forma autossuficiente e isolada. Há, portanto, uma zona de grande incerteza quanto ao papel desempenhado pelo estado, seus poderes e limites. Nesse sentido, permanece ainda hoje um grande desafio de penetração das instituições democráticas. 
Apesar da transposição de regimes políticos dos países que dominaram Timor-Leste, nenhuma deles levou consigo o conceito de estado democrático de direito.

Inicialmente, Portugal instalou uma administração para o território timorense em Dili e realizava alianças com os chefes locais. Não houve efetivamente uma penetração das instituições políticas portuguesas na organização política de Timor-Leste. Ao contrário, utilizaram-se alianças com líderes locais, atribuindo aos chefes dos reinos (liurais) o título de Dom, o que fez com que o poder se mantivesse fragmentado. Assim, não foi possível que se formasse um sentimento de unidade nacional. Tampouco foi difundida a compreensão do funcionamento da organização das instituições políticas do estado português. $^{144}$

A constatação de que um senso de unidade não se desenvolveu durante o período colonial torna-se evidente quando se analisa o período de conflito interno que antecedeu a invasão indonésia. Parte substancial dos timorenses apoiavam a anexação ao país vizinho. Foi somente diante da discriminação que o governo da Indonésia fazia em relação aos timorenses durante o período de ocupação, que um senso de unidade timorense começou a ser forjado.

Posteriormente, com a anexação, as estruturas políticas transpostas caracterizavam-se pelo autoritarismo do poder estatal, que tudo pode, não havendo qualquer tipo de limitação ou garantia individual. Nesse contexto, as instituições políticas não passavam de instrumentos para a manutenção do regime autoritário, servindo portanto unicamente à vontade dos chefes políticos. Sob a perspectiva autoritária, as instituições políticas estão a serviço da manutenção do poder. Assim, o estado priorizava as necessidade básicas materiais da população, como o acesso à alimentação, a fim de garantir a pacificação social. Ainda sim, esse estado o fazia na medida em que servia a seus próprios interesses, já que não havia qualquer mecanismo que garantisse efetivamente a participação popular.

As instituições indonésias lograram penetrar no seio da comunidade timorense, mas os conceitos carregados consigo foram os de instituições autoritárias, desenhadas para apoiar o regime central de Jakarta em sua política de dominação. Assim, o conceito de estado trazido para Timor-Leste foi o do estado autoritário com forte apelo à ideologia nacional (Pancasila). Durante o período de ocupação, mesmo as instituições civis eram controladas pelos militares, deixando a população civil à margem das decisões de

${ }^{144}$ CAVR. Relatório Chega! Introdução, 2005, p. 4. 
estado. ${ }^{145}$ Os timorenses jamais se sentiram integrados na sociedade indonésia, conforme assinala Benedict Anderson:

Creio que o resultado tem sido uma profunda incapacidade para imaginar Timor-Leste como indonésio... A linguagem é a do superior e civilizado em relação ao inferior e bárbaro. Não anda muito longe do racismo e revela uma profunda incapacidade para "incorporar" os timorenses do leste, um sentimento não reconhecido de que na verdade eles são estrangeiros. ${ }^{146}$

Apesar de haver um esforço político no sentido de integrar Timor-Leste a ideia de grande Indonésia (Indonesia Raya), aos timorenses não eram garantidos os mesmos direitos, levando assim a uma marginalização. Para integrar o serviço público, por exemplo, um timorense teria que adquirir a cidadania indonésia. Em um movimento de reação à discriminação sofrida a partir da ocupação indonésia, um senso unitário de identidade timorense começou efetivamente a tomar corpo, pois até então Timor-Leste era composto por comunidades isoladas e autossuficientes, com línguas e tradições diferentes, sem vínculos identitários suficientemente fortes.

A organização segmentada ainda predomina no dias atuais, mesmo após a independência do país. O que evidencia-se por exemplo através das tensões entre comunidade e famílias que levaram à uma escalada da violência em 2006. Assim, o senso de pertencimento ao estado de Timor-Leste, enquanto unidade nacional, permanece em um plano secundário quando comparado ao senso de pertencimento de cada indivíduo enquanto membro da comunidade local e integrante da família alargada. ${ }^{147}$ Daí porque, diante da história timorense, emerge a necessidade de construção de uma identidade nacional em um sentido unitário.

A crise de 2006 demonstrou que a sustentação de um estado nacional faz imprescindível o desenvolvimento da ideia de nação, em que os indivíduos e comunidades reconheçam seu vínculo identitário, garantindo assim a necessária legitimidade e coesão

\footnotetext{
${ }^{145}$ Não há, portanto na história do povo timorense qualquer referência anterior ao estado democrático e à soberania popular. Como consequência, os conceitos de instituições democráticas, de ideologia liberal que carrega consigo, bem como da ideia de direitos humanos e proteção das minorias perde a vinculação histórica que lhe oferece um importante sustento. A transposição desses conceitos, sem que se compreenda o histórico de lutas sociais e de rupturas leva muitas vezes a atritos entre a visão ocidentalizada de estado de direito e as instituições tradicionais de Timor-Leste.

${ }^{146}$ ANDERSON, Benedict. Imaginar Timor Leste.Tradução de Osvaldo M. Silvestre in de Arena Magazine 4, Abril-Maio 1993, p. 3.

${ }^{147}$ Essas tensões locais culminaram no conflito de 2006, levando a um grande número de refugiados a à reformulação da operação de manutenção de paz da ONU.
} 
social. O desenvolvimento dessa identidade nacional guarda uma relação inseparável com a memória. Para dialogar com Paul Ricoeur: "No plano mais profundo, o das mediações simbólicas da ação, a memória é incorporada à constituição da identidade por meio da função narrativa". ${ }^{148}$ Assim, o recurso à memória coletiva permite que se formule um vínculo de identidade a partir das experiências comuns.

Ao considerar a inseparabilidade dos conceitos de memória e identidade, torna-se evidente o papel da CAVR para formulação da identidade nacional timorense. Ao narrar os fatos e violações envolvidos na luta pela independência, cria-se uma memória coletiva que imprime solidez à identidade nacional.

Essa construção exige que se percorra um longo caminho, pois não se trata apenas de forjar uma identidade, mas também de compreensão do papel do estado de direito. A mudança de concepção constitui um processo complexo, onde sobressaem pontos de fricção. Assim, enquanto o estado de direito pressupõe a participação dos cidadãos, como detentores da soberania popular, existe pouca informação e compreensão a respeito do papel que cada cidadão desempenha e do papel exercido por cada instituição sob a qual se sustenta a sociedade democrática.

Nesse contexto, a CAVR revelou-se como uma ponte no sentido de unir essas concepções dissonantes de organização política e social. Por se tratar de um mecanismo alternativo de solução de disputas, que ao mesmo tempo integra a comunidade no processo e traz elementos do poder estatal, a CAVR teve esse importante papel no sentido de aproximar essas realidades dissonantes. Portanto, a CAVR contribuiu não somente na construção da memória coletiva e identidade nacional, mas também permitiu a aproximação das instituições que caracterizam cada uma das duas formas de ordenamento social: estado de direito e sociedade segmentada.

Outro importante fator a influenciar os trabalhos da CAVR foi a existência de um sistema de justiça tradicional prévio. As sociedade segmentadas contam com seus próprios mecanismos de solução de disputas, que não se assentam sobre o poder estatal, mas sobre o reconhecimento de autoridades locais. Em Timor-Leste não é diferente. Essa forma de solução de disputas foi determinante para os trabalhos da CAVR, que incorporou os rituais e cerimonias no Processo de Reconciliação Comunitária (PRC).

A sobrevivência da justiça tradicional em Timor-Leste se deve ao fato de que durante o período colonial português não houve uma efetiva penetração das instituições

${ }^{148}$ RICOEUR, Paul. A memória, a história, o esquecimento. Campinas: Editora Unicamp, 2007, p. 98. 
estatais. Mesmo, durante a ocupação indonésia, que foi muito mais eficiente nesse sentido, os métodos locais de solução de disputas (nahe biti) permaneceram. Durante a ocupação indonésia muitos assuntos eram considerados de interesse privado, pelo que a resolução de um conflito que surgisse nesse âmbito, poderia ser feita de acordo com os mecanismos de justiça tradicional, sem que houvesse a interferência do poder estatal. Ademais, o fato de o sistema judiciário indonésio operar a serviço do regime militar, também levou ao afastamento do poder judiciário em relação à sociedade timorense. Em razão do impacto limitado das instituições judiciárias, tanto no período português, quanto durante a ocupação indonésia, os métodos informais de resolução de conflitos foram preservados como parte da cultura timorense.

Até os dias de hoje há uma forte resistência em se recorrer ao judiciário. ${ }^{149}$ Assim, os arranjos comunitários para o endereçamento dos conflitos fazem parte da própria tradição e cultura do país. Conforme assinala Daniel Simião:

\begin{abstract}
No caso de Timor-Leste, contudo, não temos apenas uma sensibilidade jurídica operante, mesmo dentro do sistema judicial patrocinado pelo Estado. As formas locais de justiça operam com sensibilidades jurídicas próprias, traduzindo plano normativo e interpretação dos fatos por meio de outras gramáticas. Muitos dos problemas de aceitação da justiça estatal por parte da população vêm desta diferença de sensibilidades jurídicas um desencontro que impede que o resultado final seja percebido como justo; impede um sentido de equidade (fairness). ${ }^{150}$
\end{abstract}

$\mathrm{Na}$ justiça tradicional o arcabouço de valores e símbolos que servem como referencial da norma são completamente diversos dos conceitos insculpidos na justiça estatal. Enquanto o poder judiciário baseia-se em uma conceito individualista de justiça, a justiça tradicional de Timor-Leste estrutura-se sobre uma concepção coletiva. Essa diferença fundante leva a um afastamento das instâncias judiciais em relação à sociedade, em razão da não correspondência de paradigmas.

Esse distanciamento entre a jurisdição estatal e as formas tradicionais de justiça tem levado a sérios desafios institucionais para o país. Porém, a CAVR logrou conciliar essas

\footnotetext{
${ }^{149}$ BELTRAMI, Priscila A. A eficácia do acesso à justiça e a reconstrução institucional em regiões pósconflito: contribuição ao marco teórico da reconstrução de sistemas de justiça. Dissertação (Mestrado em Direito) - Faculdade de Direito, Universidade de São Paulo, São Paulo, 2011, p. 92.

150 SIMIÃO, Daniel Schroeter. Sensibilidade jurídica e diversidade cultural: dilemas timorenses em perspectiva comparada. In: SILVA, Kelly; SOUZA, Lúcio (orgs.). Ita maunalin: o livro do irmão mais novo. Lisboa: Edições Colibri, 2011, p.5.
} 
diferentes visões de mundo e justiça ao incorporar os mecanismos tradicionais. Sobre o papel do nahe biti Dionísio Babo-Soares assinala com propriedade:

\begin{abstract}
Reconhece-se que a variação na implementação do Nahe Biti entre os diferentes grupos etno-linguísticos em Timor Leste é inevitável. No entanto, a ênfase está no envolvimento direto das pessoas neste processo que, com todas as suas razões filosóficas, garante que uma paz longa e duradoura possa ser alcançada, sem prejudicar o valor da justiça. Além disso, para além de ser eficaz, esse método é menos dispendioso e menos demorado. Sobretudo, para a população local, apresenta um compromisso e uma maneira de recuperar, efetivamente reestabelecer, a ordem social anterior, previamente devastada. ${ }^{151}$
\end{abstract}

Assim, as formas tradicionais de solução de disputas consideram sobretudo as estruturas sociais e a harmonia da comunidade. Essa realidade influiu positivamente para o funcionamento da CAVR, conforme apontado no relatório final: "a audiência demonstrou a importância de coligar elementos do processo legal formal aos costumes tradicionais. A combinação destas duas fontes conferiu total legitimidade ao processo, aos olhos dos membros da comunidade". ${ }^{152}$

O modelo institucional da CAVR refletiu, portanto, a tradição timorense de mecanismos de solução de disputas, ao mesmo tempo em que incorporou padrões internacionais de direitos humanos. Ao invés de se apoiar em um centralismo jurídico, que seria infrutífero, a CAVR, de maneira perspicaz, reconheceu a importância de uma visão pluralista, encarando de maneira positiva a multiplicidade de fontes, instâncias e processos. $^{153}$

A maneira positiva com que os processo locais foram integrados nos trabalhos da CAVR é também reflexo das bases conceituais sobre os quais estão alicerçadas as

\footnotetext{
${ }^{151}$ It is acknowledged that variation in the implementation of nahe biti among different ethno-linguist groups in East Timor cannot be avoided. Nevertheless, the emphasis here is that direct involvement of the people in this process, with all its philosophical reasons, guarantees that a long and lasting peace can be achieved without undermining the value of justice. Furthermore, apart from being effective, this approach is less costly and less time consuming. Most importantly, for the local people, it does present a compromise and a way to recover, indeed re-establish, the previously devastated social order. SOARES, Dionísio Babo. NaheBiti: The Philosophy and Process of Grassroots Reconciliation (and Justice) in East Timor. In: The Asia Pacific Journal of Anthropology.vol.5, n.1, abril, 2004, p. 31.

${ }^{152}$ CAVR. Relatório Chega! Introdução, 2005, p. 25.

${ }^{153}$ Sobre a centralidade jurídica e o acesso à justiça: "entenda-se por jurisdiciocentrismo a obsessão de analisar o fenômeno da resolução de controvérsias apenas pela lendo dos deveres, faculdade e ônus processual. LORENCINI, Marco Antonio Garcia. Prestação jurisdicional pelo estado e meios alternativos de solução de controvérsias: convivência e formas de pacificação social. Tese (Doutorado em Direito) Faculdade de Direito, Universidade de São Paulo, São Paulo, 2009, p. 86.
} 
comissões da verdade. Apoiam-se em conceitos de reconciliação e mediação dos conflitos, representando uma alternativa ao poder judiciário. Portanto, partem do mesmo conceito de solução pacífica dos conflitos, que marca os métodos tradicionais de justiça local em Timor-Leste. De maneira, que a cultura local permitiu que os integrantes da comunidade compreendessem o trabalho desenvolvido pela CAVR e participassem ativamente nesse processo.

Além do próprio processo de composição dos conflitos que marca a organização social timorense, é igualmente necessário, para análise dos trabalhos da CAVR, a compreensão dos fatores da comunicação e do uso da linguagem, que tiveram uma considerável influência nos resultados apresentados. O multilinguismo, a oralidade e o simbolismo são traços característicos da cultura timorense. Embora o português e o tetum sejam as línguas oficiais de Timor-Leste atualmente, existem mais de 35 idiomas de tradição oral. Em que pese a oficialidade do português, não é ainda amplamente utilizado, prevalecendo apenas para assuntos oficiais relacionados à atuação estatal, gerando assim um distanciamento ainda maior entre a população e as instituições estatais.

Diante desse contexto, a CAVR notou que os processos de reconciliação comunitária só seriam efetivos, se a comunicação estabelecida fosse realizada nos idiomas locais. Naturalmente que isso representou uma série de dificuldades de ordem prática, sobretudo para a preparação do relatório final. Por outro lado, a condução dos processos nos idiomas locais permitiu aproximação junto às comunidades.

É preciso notar que, apesar da enorme variação linguística, em comum as línguas locais caracterizam-se por uma linguagem não escrita. Nas tradições orais, a lembrança dos anciãos torna-se, portanto, fonte das regras do grupo. ${ }^{154} \mathrm{~A}$ oralidade é a tradução da memória viva. A memória e o passado exercem um papel central nessas sociedades. Nesse sentido, as fontes normativas emanam da tradição, revelada através dos conceitos e histórias contadas pelos anciãos. Assim, a narração das experiências passadas, constitui-se um importante mecanismo de manutenção da coesão social. O vínculo entre o presente e o passado possui uma importância primordial nas sociedades marcadas pela oralidade. É o ato de recontar e rememorar que garante a perenidade do grupo através do tempo e os laços de comunhão no presente. Ademais, a oralidade e valorização da memória foram também fatores importantes na estratégia de resistência, pois garantiam um maior sigilo às

${ }^{154}$ DINIZ, Debora. Antropologia e os limites dos direitos humanos: o dilema moral. In: NOVAES, Regina Reyes, LIMA, Roberto Kant de (Org.). Antropologia e direitos humanos. Niterói: Editora da Universidade Federal Fluminense, 2001. 17-46 p. 
informações, ao mesmo tempo em que preservavam a identidade e estratégia dos opositores.

Esses fenômenos contribuíram favoravelmente para o sucesso dos trabalhos da CAVR. A valorização da memória é um dos eixos centrais a guiar os trabalhos de comissões da verdade, de maneira geral. Assim, a CAVR baseou-se em uma profunda compreensão social do papel que a memória exerce, permitindo que ela se desenvolvesse em consonância com a cultura local.

Memória viva e memória escrita, devem ser analisadas sob um ótica de complementariedade. A memória viva afigura-se como uma lembrança inscrita na alma. ${ }^{155}$ Ao passo que, a memória escrita proporciona uma rememoração. A relação entre elas não é de substituição. Assim, a CAVR, ao estabelecer um registro histórico através dos relatórios, não vem destituir a memória oral do seu papel. Ao contrário, utiliza essa tradição local a seu favor. Ao oferecer um espaço às diferentes vozes, encampou as diferentes percepções do momento histórico vivido.

Ao contrário do que se pode pensar em uma análise superficial, essa valorização das diferentes vozes não se opõe ao objetivo de apurar a verdade factual. São inúmeras as teses que argumentam no sentido de não haver uma única verdade, sendo esta variável a depender do ponto de vista que se toma, o que impediria a formulação de ume verdade objetiva. Para essa corrente, na realidade, a percepção de cada ator ou expectador envolvido nos fatos cria diferentes concepções a respeito da verdade dos fatos.

Ocorre que, conforme já apontado neste trabalho, não se pode confundir a verdade factual com opinião ou mesmo interpretação. Uma comissão da verdade, tal como a CAVR, ao se propor apurar a verdade, se compromete a trazer à luz os fatos e o contexto envolvendo graves violações de direitos humanos. Nesse processo, realiza escolhas metodológicas, que normalmente incluem consultas a documentos, a oitiva de vítimas e a recolha de testemunhos. A partir daí traça um panorama dos acontecimentos. Uma verdadeira comissão da verdade não se propõe a ser uma justiça dos vencedores, mas se compromete a trazer a público os fatos negados ou ocultados.

Simultaneamente, as comissões da verdade também se constituem em um espaço de catarse das vítimas. Assim, finalmente lhes é dada a oportunidade de serem ouvidas. Isso não implica reescrever a história segundo a visão dessas vítimas, e sim em promover um espaço para que se ouçam as diferentes vozes a fim de compor o quadro maior de

${ }^{155}$ RICOEUR, Paulo. A memória, a história, o esquecimento. Campinas: Editora Unicamp, 2007, p. 153. 
violações. Assim, o objetivo de apuramento e revelação da verdade não se contradiz e também não se confunde com a abertura de espaço para participação das vítimas. Ao contrario, tratam-se de papéis complementares.

Por fim, ainda no que se refere ao uso da linguagem e a sua relação com os trabalhos da CAVR, outro fator deve ser apontado: a importância da simbologia e das palavras sacramentais na cultura local. A cultura timorense é marcada por cerimonias revestidas de simbolismo, como por exemplo, o ato de estender um tapete nas cerimônias de nahe biti. Outro exemplo, consiste na incorporação do tais - tecido tradicional - como elemento da tradição utilizado em ocasiões especiais. Existem outros inúmeros exemplos que evidenciam o culto aos símbolos. Essa mesma simbologia também se estende ao uso de palavras sacramentais. Entretanto, em razão da própria estrutura linguística e da oralidade, essas palavras sacramentais se traduzem em um empirismo que pode assumir muitas formas diferentes. Assim, o conceito preciso da terminologia empregada pode receber interpretações muito dispares a depender do contexto. Mas, a sacramentalidade do termo permanece.

A incorporação desses valores nas cerimônias de reconciliação promovidas no âmbito da CAVR, foi um fator de extrema relevância para o sucesso dos seus trabalhos. Juntamente com as formas tradicionais de justiça, a CAVR incorporou também os procedimentos ritualísticos com ela relacionados, o que permitiu uma aproximação com as comunidades locais.

A compreensão da cultura local e da organização social timorense foi portanto essencial no planejamento, nos trabalhos e nos resultados apresentados pela CAVR. Assim, para análise de seu funcionamento exige-se igualmente essa contextualização. Além disso, a função da memória para a formação da identidade nacional timorense e do papel de apuramento da verdade só podem ser compreendidos em sua inteireza quando reconhecido o papel da linguagem e da justiça tradicional, aliado às experiências históricas de TimorLeste.

\subsection{Elementos da justiça de transição em Timor-Leste}

A partir do referendo de 1999 e com a retirada da Indonésia, surgiu um forte apelo pela investigação e apuração dos crimes ocorridos durante o domínio indonésio a que Timor-Leste foi submetido. Em pleno terceiro milênio e diante da conjuntura mundial 
parecia inadmissível que os crimes cometidos contra a população local permanecessem impunes. Era necessário, portanto, traçar uma política transicional que fosse capaz de endereçar as necessidades imediatas e futuras e ao mesmo tempo absorver as peculiaridades do contexto local. A CAVR foi um dos mecanismos escolhidos, mas outros elementos também compuseram o cenário do pós-conflito.

Assim, defendeu-se a criação de um tribunal penal internacional, que, entretanto não chegou a ser criado. Por outro lado, foram criadas outras instituições que operavam em função desse período de transição. O Tribunal $A d$ hoc em Jakarta, capital da Indonésia, tinha por fim investigar e punir os atentados contra os direitos humanos cometidos no Timor-Leste. A Comissão Nacional de Direitos Humanos da Indonésia também criou uma comissão especial para violações de direitos humanos em Timor-Leste (KPP-HAM). À KPP-HAM foi atribuída a competência para investigar as violações de direitos humanos ocorridas no contexto do referendo de 1999. Seu relatório foi submetido ao procurador geral da Indonésia, mas seu impacto foi bastante limitado.

Foram também criados Painéis Especiais para investigação e persecução penal dos crimes. Tratavam-se de painéis híbridos, criados durante a administração da UNTAET e instalados na capital Dili. Paralelamente, foram instaladas duas comissões da verdade: a Comissão de Acolhimento Verdade e Reconciliação (CAVR) e a Comissão de Verdade e Amizade (Comission for Truth and Friendship - CFT), que foi uma comissão mista para apuração da verdade, entre Timor-Leste e Indonésia.

À CAVR competia colaborar com as investigações realizadas no âmbito de competência de julgamento dos Painéis Especiais. Essa relação é relevante na medida em que influenciou os trabalhos da CAVR. Com efeito, o prosseguimento dos processos de reconciliação desenvolvidos no seio da CAVR, dependiam de uma concordância do procurador geral, responsável por apurar os crimes dos painéis especiais. No entanto, a obrigatoriedade de comunicação entre a CAVR e a unidade de investigação especial, trouxe um certo receio em revelar certos crimes e detalhes a respeito das circunstâncias envolvendo as violações.

De maneira que é importante compreender essas interações entre a CAVR e os demais elementos da justiça de transição. Conforme apontado diversas vezes, os mecanismos disponíveis para a formulação de uma política e de uma justiça de transição são múltiplos e variados e devem atuar em sinergia. A escolha metodológica e institucional depende, portanto das variáveis sociais, culturais e histórias enfrentadas. Foram 
identificados quatro elementos caracterizadores da justiça de transição: responsabilização, reparação, reforma institucional e comissões da verdade. ${ }^{156}$ Esses elementos interagem em forma de rede complexa, exercendo influências mútuas.

Em razão dessa complexidade sistêmica, é necessário ter-se em conta as limitações metodológicas desta análise. Tem-se por foco, neste trabalho, as comissões da verdade, sob a perspectiva concreta da CAVR e o seu papel na apuração da verdade. Mas, compreender o funcionamento da CAVR exige preliminarmente a compreensão contextual da justiça de transição e seus elementos em Timor-Leste, sem os quais é impossível apreender a dimensão e os resultados dos trabalhos da CAVR. Mesmo quando a prática revela uma ausência de diálogo entre os mecanismos simultaneamente empregados, é preciso ter-se uma perspectiva holística a fim de compreender as contingências que os cercam, bem como as incompatibilidade, incoerências e desafios.

\subsubsection{Os tribunais e a responsabilização criminal}

A responsabilização pelas violações de direitos humanos talvez seja um dos maiores desafios das políticas transicionais, porque encontra óbices de ordem política, em razão do prestígio conservado pelos autores das violações e em razão da fragmentariedade da sociedade que emerge. O Conselho de Segurança da ONU manifestou-se diversas vezes ressaltando a necessidade de assegurar a responsabilização pelas graves violações de direitos humanos ocorridas em Timor-Leste. Foi então estabelecida, pelo Secretário Geral da ONU, em 2005, a Comissão de Experts para Timor-Leste, composta por Prafullachandra Bhagwati (India); Yozo Yokota (Japão) e Shaista Shameem (Fiji). Sua finalidade era acompanhar os trabalhos levados a cabo pelos Painéis Especiais e também pelo Tribunal Ad hoc de direitos humanos para Timor-Leste, em Jakarta. ${ }^{157}$

A Comissão de Experts recomendou a criação de um tribunal internacional, em um terceiro país, caso Indonésia e Timor-Leste não conseguissem seguir as recomendações no sentido de garantir a responsabilização penal e um processo adequado. $\mathrm{O}$ estabelecimento de comissões de experts, na Iugoslávia e em Ruanda, levaram à criação de

\footnotetext{
${ }^{156}$ Vide capítulo 2.3.2.

157 ONU. Carta do Secretário Geral da ONU endereçada ao Conselho de Segurança. S/2005/96 Disponível em: $\quad<$ http://daccess-dds-ny.un.org/doc/UNDOC/GEN/N05/243/59/PDF/N0524359.pdf?OpenElement> Acesso em: 02.09.2014.
} 
um tribunal internacional para cada um dos casos. Havia, portanto, uma forte expectativa de que o mesmo ocorresse no caso de Timor-Leste. Entretanto, a realidade revelou a dificuldade em se estabelecer tal tribunal, que jamais chegou a ser criado.

Os obstáculos políticos e a forte influência dos militares indonésios mesmo após a queda do General Suharto foram suficientes a ponto de deter a criação de um tribunal internacional e a tentativa de responsabilização dos escalões hierárquicos mais altos do governo. Isso porque, mesmo com a mudança de regime na Indonésia, a herança militar permaneceu enraizada no seio de uma sociedade que ainda hoje preza pela hierarquia e obediência devida.

A cultura indonésia, sobretudo a cultura Javanesa, ilha central onde se situa a capital Jakarta, é marcada pelo louvor à ordem. ${ }^{158}$ Assim, a submissão a um poder autoritário justifica-se com a finalidade de garantir ordem, estabilidade e continuidade. ${ }^{159}$ Nesse sentido, o questionamento das decisões de estado e dos altos escalões da hierarquia militar entram em choque com os valores predominantes da cultura local, dificultando qualquer tipo de responsabilização. Naturalmente, que existem vozes dissonantes e que advogam em favor dos direitos humanos, bem como da necessidade de responsabilização pelos crimes cometidos, mas a influência exercida pelos militares ainda hoje é decisiva na política da Indonésia. ${ }^{160}$

O apreço pela ordem e estabilidade, que caracterizam a cultura indonésia foi apropriado pela doutrina militar, justificando assim seu envolvimento na burocracia e na condução política do país. Nesse contexto, foi forjado o conceito de dwifungsi, que significa uma dupla função. De acordo com essa doutrina, os militares deveriam, por um lado, garantir a segurança externa e por outro, promover o desenvolvimento e a estabilidade política. ${ }^{161}$ Atualmente, em que pese o dwifungsi não fazer mais parte da política oficial do país, é certo que a essência dessa doutrina permanece enquanto herança no seio da sociedade indonésia, fator que dificulta a responsabilização pelos crimes praticados durante o regime militar.

A política repressiva e autoritária não se restringiram ao território timorense. A geografia da Indonésia, composta por dezenas de ilhas e o histórico de movimentos

${ }^{158}$ A esse respeito, importante retomar a discussão sobre a relação entre valores asiáticos e direitos humanos e o que Huntington chamou de choque das civilizações vide capítulo 2.2.1.

${ }^{159}$ SEBASTIAN, Leonard C. Realpolitik Ideology Indonesia's Use of Military Force. Singapore: Institute of Southeast Asian Studies, 2006, p. 11.

${ }^{160}$ HONNA, Jun. Military Politics and Democratization in Indonesia. London: Routledge, 2005.

${ }^{161}$ Idem. 
libertários levou a uma extrema centralização do poder, em torno da capital Jakarta e ao desenvolvimento de uma espécie de paternalismo estatal. Com efeito, houve forte repressão, resultando em diversas violações de direitos humanos por todo o país, na tentativa de conter esses movimentos. Até hoje, mesmo com o fim do regime militar, permanecem os conflitos na Papua do Oeste, entre os movimentos independentistas e o governo central de Jakarta. Ainda mais intensos eram os conflitos à época do governo de Suharto, que reprimia violentamente qualquer tentativa de contestação do poder central, com meios tipicamente característicos das ditaduras militares da segunda metade do século XX.

Portanto, a responsabilização pelos crimes cometidos não é apenas uma questão timorense, mas está inserida em um contexto maior e sistêmico de repressão estatal que caracterizou o estado indonésio. Apesar da reforma política com a saída de Suharto, os militares ainda hoje detém grande prestígio e poder político, o que se mostrou um enorme obstáculo na sua responsabilização. A instalação de um tribunal internacional, foi assim inviabilizada, em razão da grande influência exercida pelos militares indonésios.Com efeito, a realidade revela que as forças políticas e a pressão de grupos de poder são determinantes no delineamento da justiça de transição.

A não instalação de um tribunal internacional, resultou não apenas do prestígio político ainda gozado pelos militares indonésios, mas da própria posição assumida pelo governo timorense, de não pressionar pela criação de um tribunal internacional, colocando os interesses econômicos à frente e adotando uma visão de realpolitik. Em razão da ausência de vontade política de ambos os países, restou silenciado o clamor dos defensores de direitos humanos, ONGs e de própria parcela da sociedade timorense e indonésia, que defendiam criação de um tribunal internacional.

Mas, se a criação de um tribunal internacional não foi possível, restava ainda em aberto uma segunda alternativa para garantia de responsabilização criminal: o Tribunal Penal Internacional. Timor-Leste aderiu ao Tratado de Roma, aceitando a jurisdição do tribunal em setembro de 2002. Entretanto, revelaram-se dois obstáculos em relação à jurisdição do tribunal. Primeiramente, em relação ao aspecto temporal, o TPI não possui competência para julgar crimes anteriores à sua entrada em vigor, em $1^{\circ}$ de julho de $2002 \mathrm{e}$ nem anteriores à adesão do estado parte, conforme previsto no artigo 11 do estatuto. Ademais, embora Timor-Leste seja um estado membro do TPI, a Indonésia até hoje não aderiu ao tratado, impossibilitando portanto o reconhecimento da competência do tribunal. 
A impossibilidade de se recorrer aos tribunais internacionais, porém, não esgotou todas as possibilidades de responsabilização criminal. Assim, foram instalados tribunais híbridos, chamados de Painéis Especiais, através do regulamento UNTAET 11, de 2000. Ao instituir o sistema judicial, atribuiu ao Tribunal Distrital da capital Dili a competência exclusiva para os crimes graves de: genocídio, crimes de guerra, crimes contra a humanidade, assassinato, crimes sexuais e tortura (artigo 10.1). Para tanto, permitiu-se a criação de câmaras especializadas, integradas por juízes nacionais e internacionais. $\mathrm{O}$ mesmo foi previsto, no artigo 15.5. do regulamento 11/2000 em relação ao Tribunal de Apelação. Essas câmaras do Tribunal Distrital de Dili e do Tribunal de Apelação formaram os Painéis Especiais para Crimes Graves. A competência desses painéis foi prevista em detalhes no regulamento UNTAET 15 de 2000, que dispôs sobre a criação de câmaras com jurisdição exclusiva sobre delitos criminais graves.

Embora o trabalho dos Painéis Especiais tenha sido elogiado por sua celeridade e eficiência dos crimes processados, outros desafios de ordem prática predominaram. A atuação dos painéis foi prejudicada pelo fato de que aqueles que se encontravam nos mais altos escalões responsáveis pelos crimes praticados encontravam-se na Indonésia. Isso gerou um sentimento de impunidade e de que a maior parte dos condenados foram os timorenses e não os indonésios, que efetivamente exerciam o comando sobre as operações. $\mathrm{Na}$ prática, todas as acusações foram feitas com base no crime contra a humanidade, ou com base na lei doméstica. ${ }^{162} \mathrm{~A}$ falta de cooperação por parte da Indonésia fez com que, dos 391 indiciados, 309 permanecessem fora da jurisdição dos painéis. ${ }^{163}$ Assim, embora tenha havido um grande esforço para garantir a responsabilização criminal, houve um esvaziamento dos painéis, que não conseguiram alcançar os chefes de comando.

Os Painéis Especiais, juntamente com a CAVR compunham o quadro de justiça transicional projetado pela ONU, através de sua missão de paz. O regulamento UNTAET 10, de 2001, que estabeleceu a CAVR, previu um mecanismo de reconciliação comunitária, de acordo com o qual, alguns crimes menores poderiam ser julgados em audiências públicas locais, incorporando o sistema de justiça tradicional timorense (adat). Esses processos locais eram denominados Processo de Reconciliação Comunitária (PRC). Para isso, o caso primeiramente era enviado à promotoria responsável pela acusação nos

162 REIGER, Caitlin, WIERDA, Marieke. The Serious Crimes Process in Timor-Leste: In Retrospect. Internacional Centre for Transitional Justice. 2006, p. 23. Disponível em: $<$ http://www.ictj.org/sites/default/files/ICTJ-TimorLeste-Criminal-Process-2006-English.pdf $>$ Acesso em 20 de set de 2014.

${ }^{163}$ Idem, p. 21. 
crimes de competência dos Painéis Especial. Não sendo um crime grave, o processo se desenrolava a nível local. A promotoria também tinha livre acesso à documentação e informação da CAVR. Por outro lado, o mesmo direito não era garantido à defesa, o que levou a um certo desequilíbrio processual. ${ }^{164}$

Ainda em relação ao diálogo institucional, é necessário pontuar que o estabelecimento pela UNTAET dos Painéis Especiais em nada obstava a criação de um tribunal internacional. Ao contrário, havia grande esperança de que os crimes praticados ainda pudessem ser julgados por um tribunal internacional, conforme já apontava o próprio regulamento 11/2000 em seu artigo 10.4:

10.4. O estabelecimento de câmaras com competência sobre delitos criminais graves não afetará a competência de um tribunal internacional para o Timor-Leste sobre tais, quando este tribunal vier a ser criado.

Mas, ao invés da criação de um tribunal internacional, instalou-se o Tribunal $A d$ Hoc em Jakarta. Sua criação foi vista por analistas e observadores como uma tentativa da Indonésia de evitar a internacionalização desse processo, mantendo o controle sobre o julgamento. Conforme orientação da Comissão de Experts, só deveria ser criado um tribunal internacional, se Timor-Leste e Indonésia não fossem capazes de tratar da questão. A instalação desse Tribunal $A d$ Hoc em Jakarta foi vista como um jogo de aparências, para assegurar que os militares indonésios não fossem processados em outra instância judicial. Ainda, de acordo com o relatório da Comissão de Experts para Timor-Leste, os trabalhos do tribunal e da acusação não tiveram credibilidade e não garantiram a adequada responsabilização. ${ }^{165}$ No mesmo sentido posicionaram-se as organizações não governamentais. De acordo com a Human Right's Watch, o Tribunal Ad hoc de Jakarta foi um grande fracasso. ${ }^{166}$

Não se estabeleceu um diálogo entre o Tribunal $A d H o c$ com as demais instituições transicionais essencialmente porque eram movidos por princípios e motivações políticas diversas. Se por um lado o alto escalão do comando militar não estava ao alcance

\footnotetext{
164 Não obstante, parece não ter havido uma grande contribuição do PRC aos trabalhos da promotoria especial, conforme apontam os estudos. Idem, p.35.

${ }^{165}$ ONU. Carta do Secretário Geral da ONU endereçada ao Conselho de Segurança. S/2005/96 Disponível em: $\quad<$ http://daccess-dds-ny.un.org/doc/UNDOC/GEN/N05/243/59/PDF/N0524359.pdf?OpenElement> Acesso em: 02 de set de 2014.

166 HUMAN RIGHTS WATCH. Justice Denied for East Timor. Disponível em: $<$ http://www.hrw.org/legacy/backgrounder/asia/timor/etimor1202bg.htm> Acesso em 02 de set de 2014.
} 
da jurisdição dos Painéis Especiais, situados em Dili, também não foram efetivamente processados e julgados no Tribunal $A d H o c$ de Jakarta, deixando assim em aberto a questão da responsabilização criminal pelas violações de direitos humanos e o combate à impunidade.

\subsubsection{Dever de Reparação}

A reparação é um fator essencial quando se analisam políticas transicionais. Tratase de um conceito amplo cujo conteúdo consiste em restaurar a condição anterior à violação de um direito ou, quando isso não for possível, a promover alguma forma de compensação. A reparação, como elemento da justiça de transição tem como foco primordial as vítimas das violações de direitos humanos. Sob esse prisma, implica um conjunto de medidas voltadas à restituição, através da compensação e reabilitação da vítimas, bem como a satisfação e a garantia de não recorrência. ${ }^{167}$

Para uma análise apropriada do dever de reparação, há três discussões centrais: determinar a quem compete o dever de reparação; determinar o sujeito passivo das obrigações e as formas de reparação. Em Timor-Leste a questão as reparações ao lado da responsabilização, talvez tenha sido um dos aspectos mais problemáticos da justiça de transição, uma vez que não houve um amplo programa nesse sentido. As causas dessas dificuldades serão a seguir apresentadas, bem como a relação existente entre as reparações e a CAVR.

Primeiramente, é necessário discutir a quem incumbe o dever de reparação. A responsabilidade de reparar pode recair sobre um estado, por sua ação ou omissão. Pode também recair sobre o indivíduo ou até mesmo sobre entidades coletivas, como empresas e ONGs.

Sob a perspectiva da reparação devida pelo autor do crime, a justiça de transição em Timor-Leste logrou sua promoção através da reconciliação comunitária conduzida pela CAVR. O ato de instituição da CAVR previu o Processo de Reconciliação Comunitária (PRC), como forma de justiça local focada na reconciliação. $\mathrm{O}$ ato de reconciliação, poderia traduzir-se na forma de serviço comunitário, de pedido público de desculpas,

\footnotetext{
${ }^{167}$ Para uma análise mais aprofundada dos conceitos, vide capítulo 2.1 .
} 
outra forma de constrição ou por uma reparação, conforme previsto no art. 27.7 do regulamento UNTAET 10 de 2001. Essa reparação, poderia constituir-se por exemplo no pagamento de certa quantia, ou de uma ato simbólico da entrega de um animal. Nesse sentido, pode-se dizer que as reparações individuais foram implementadas de maneira exitosa em Timor-Leste, incorporando elementos culturais que envolviam a entrega simbólica de objetos, animais e alimentos. Esse mecanismo de justiça local foi eficiente para reintegração daqueles que permaneceram no seio da comunidade. Assim, esteve voltado aos autores de crimes de menor gravidade e que mantinham relações de proximidade com as comunidades e vítimas. Portanto, a reparação devida pelos autores das violações manteve-se restrita aos pequenos ofensores, sem alcançar os oficiais indonésios de alto escalão, cuja responsabilidade, quer em matéria criminal, quer em função das reparações, jamais foi assumida.

Mas, a responsabilidade de reparação por parte dos agressores não encobre a questão central em torno das violações de direitos humanos, que diz respeito à violência institucional praticada em nome e em favor do estado. Nesse sentido, a responsabilidade estatal pela garantia de reparação revela-se como um tema espinhoso e se delineia especificamente no caso de Timor-Leste - de forma ainda mais problemática em razão da sucessão de estados e da herança indonésia.

Coloca-se então a indagação se seria possível responsabilizar o estado timorense pelas violações de direitos humanos ocorridas, exigindo-lhe a garantia de reparação. Para análise dessa questão é preciso considerar que Timor-Leste passou a ser reconhecido na ordem internacional após a desocupação Indonésia, uma vez que do ponto de vista do direito internacional foi até 1999, território sem governo, ocupado de maneira ilegal pela Indonésia. Apesar da declaração unilateral de independência de Timor-Leste em 28 de novembro de 1975, essa independência não chegou a ser reconhecida. Por isso, só é possível falar em emancipação do estado timorense em 1999, com a retirada da potência invasora. $^{168}$

A criação de um novo estado pode ser caracterizada como uma espécie de sucessão de estados, a respeito do qual existem inúmeros tratados e julgados internacionais disciplinando a transferência de obrigações, deveres e responsabilidade. Predomina entre os estudiosos de direito internacional a visão de que aos estados recém criados, não se

\footnotetext{
${ }^{168}$ Ressalta-se porém, que a independência do país só foi oficialmente reconhecida em 2002. Entre 1999 e 2002, Timor-Leste manteve-se sobre a administração da ONU.
} 
aplicam as mesmas regras gerais da sucessão de estados. Isso, porque se trata de uma circunstância muito especifica de libertação e a manutenção das obrigações, deveres e responsabilidades apenas viria a perpetuar o ciclo de dependência. Assim, não haveria como sustentar o dever de reparação do estado timorense pelo ciclo de violações de direitos humanos levadas a cabo durante a ocupação Indonésia. Cheriff Bassiouni assinala com propriedade:

Timor-Leste não está em uma posição para fazer reparações por 25 anos de violações de direitos humanos. As péssimas condições do país são impeditivas, e de qualquer maneira, seria extremamente injusto e inapropriado que um novo Estado independente, mas empobrecido, fosse o único a tentar corrigir os erros de outro Estado, sobretudo, se foi justamente aquele que sofreu com a devastação. ${ }^{169}$

Sustentar a transferência a Timor-Leste da obrigação de reparação pelas violações perpetradas pelo estado indonésio seria um contrassenso moral e jurídico. Por outro lado, é possível argumentar no sentido de que Timor-Leste tem a responsabilidade de reparar em razão das violações de direitos humanos perpetradas pela resistência, na medida em que sua atuação possa ser considerada como um ato do estado recém criado. Essa responsabilização do novo estado pelos atos promovidos pelos movimentos de libertação é o entendimento sustentado pela Comissão de Direito Internacional, criada pela Assembleia Geral da ONU e que tem competência para fazer recomendações e emitir pareceres a respeito do desenvolvimento e codificação do direito internacional. ${ }^{170}$ Portanto, do ponto de vista da teoria da continuidade Timor-Leste tornou-se responsável pelas violações de direitos humanos cometidas pela resistência, ensejando consequentemente um dever de reparação. ${ }^{171}$ Esse dever de reparação, estaria amparado na teoria de continuidade entre o movimento de resistência e o estado recém criado. ${ }^{172}$

\footnotetext{
169 "East Timor is not in a position to make reparations for 25 years of human rights violations. The dire conditions of the country preclude that, and in any event, it is most unjust and inappropriate that a newly independent but impoverished state should be the one to try to make right the wrongs of another state, worse still, one that had a role to play in its devastated condition". BASSIOUNI, M. Cherif. International Criminal Court. Leiden: Martinus Nijhoff Publishers, $3^{\mathrm{a}}$ ed. 2008, p. 265, tradução livre.

${ }^{170}$ ONU. Assembleia Geral. Resolução 94 de 11 de dezembro de 1946 1, 1946.

${ }^{171}$ Article 10

Conduct of an insurrectional or other movement

1. The conduct of an insurrectional movement which becomes the new Government of a State shall be considered an act of that State under international law.

2. The conduct of a movement, insurrectional or other, which succeeds in establishing a new State in part of the territory of a pre-existing State or in a territory under its administration shall be considered an act of the new State under international law.
} 
A realidade revela as dificuldades suscitadas por essa teoria, que raras vezes foi aplicada no direito internacional. Apesar da responsabilidade de Timor-Leste por reparações ser controvertida, uma análise mais abrangente permite concluir que uma série de ações pontuais promoveram de certa forma o direito à reparação simbólica, sem que, entretanto, integrassem em uma política nacional de reparações.

A própria CAVR, de certa forma, desempenhou um importante papel enquanto forma de reparação simbólica, embora tal objetivo não tenha sido expressamente mencionado em seu ato de criação. É possível afirmar que, através da CAVR Timor-Leste promoveu reparações na forma de satisfação e da garantia de não repetição. A satisfação enquanto forma de reparação implica o direito à verdade e também no reconhecimento oficial dos acontecimentos. O relatório da CAVR também aborda os crimes cometidos por agentes da resistência. Assim, o que se valoriza é a centralidade do papel da vítima. Ao promover o publicamente o conhecimento dos fatos, há uma satisfação tanto do direto à verdade quanto do direito à reparação.

Ademais, a CAVR também promoveu reparações no sentido da não repetição. $\mathrm{O}$ material produzido e a própria condução das audiências públicas contribuíram para a educação em direitos humanos, bem como para prevenção e resolução de conflitos, que são medidas de não repetição previstas nos Princípios e Diretrizes sobre o Direito a Recurso e Reparação para Vítimas de Graves Violações do Direito Internacional dos Direitos Humanos e Graves Violações do Internacional Humanitário, aprovado pela Assembleia Geral da ONU.

A seriedade com que os trabalhos da CAVR foram encarados, assinalam o comprometimento de Timor-Leste em promover uma justiça de transição efetiva. Com efeito, o relatório da CAVR abrange também o período da guerra civil que antecedeu a ocupação indonésia, revelando os fatos ocorridos durante o conflito interno, bem como os crimes cometidos pelos agentes da resistência. Portanto, a CAVR não deixa de ser um mecanismo de reparação simbólica ao tornar público os crimes cometidos e o sofrimento daqueles que foram vítimas da própria resistência.

A obrigação de reparar, entretanto, não se dirige somente ao estado de Timor Leste. Ao contrário, a responsabilidade que pesa sobre a Indonésia possui um peso muito

3. This article is without prejudice to the attribution to a State of any conduct, however related to that of the movement concerned, which is to be considered an act of that State by virtue of articles 4 to 9 .

172 DUMBERRY, Patrick. New State Responsibility for Internationally Wrongful Acts by an Insurrectional Movement. In: The European Journal of International Law.v. 17 n.3, 2006, p. 605-621. 
maior. Se por um lado existem controvérsias quanto à possibilidade de atribuir responsabilidades ao estado timorense, por outro, não restam dúvidas quanto à responsabilidade da Indonésia, na qualidade de estado ocupante.

$\mathrm{Na}$ Indonésia não foi instituído nenhum programa no sentido de garantir reparações às vítimas, apesar das recomendações da comissão mista da verdade, a CTF. Com efeito, a Indonésia jamais admitiu publicamente as violações de direitos humanos ocorridas durante a ocupação ou promoveu a efetiva responsabilização dos agentes do estado. A própria CTF teve seu mandato restrito aos acontecimentos de 1999, o que por si só já evidencia o posicionamento de negação da Indonésia em relação às violações anteriores ao período do referendo. Mesmo no que concerne os eventos de 1999, a Indonésia jamais mostrou-se disposta a estabelecer mecanismos de reparação.

A responsabilidade da Indonésia em reparar emerge a partir das violações de normas de duas naturezas: normas de direitos humanos e normas de direito internacional. Conforme assinala André de Carvalho Ramos:

De acordo com a teoria geral da responsabilidade internacional, o Estado infrator deve indenização financeira ao Estado vítima, caso ainda o dano não tenha sido reparado pela restituição na íntegra. Já na responsabilidade internacional do Estado por violações de direitos humanos, a indenização é devida não a um Estado vítima, mas sim ao indivíduo titular do direito protegido, que foi violado por conduta imputável ao Estado autor. ${ }^{173}$

Assim, em razão das violações de direitos humanos há um dever de reparação às vítimas. Por sua vez, as normas de direito internacional ensejam a reparação ao estado de Timor-Leste. ${ }^{174}$ Em que pese haver fortes argumentos no sentido de garantir alguma forma de reparação ao estado timorense pela Indonésia, a situação política revelou-se desfavorável. Não houve, assim, qualquer movimento a fim de reivindicar essas reparações. Muito ao contrário, a posição adotada por Timor-Leste foi a de não levar a frente qualquer demanda de reparação contra a Indonésia.

\footnotetext{
${ }^{173}$ RAMOS, André de Carvalho. Responsabilidade Internacional por violação de Direitos Humanos: seus elementos, a reparação devida e as sançães possiveis: teoria e prática. Rio de Janeiro: Renovar, 2004, p. 248

${ }^{174}$ Ademais, a invasão indonésia poderia ainda ensejar uma reparação devida a Portugal, considerando que Timor-Leste à época da anexação era território português. A partir desse ponto de vista, esse direito à reparação teria sido transmitido ao novo estado timorense, por sucessão.
} 
Num contexto transicional, quando se analisa o direito à reparação, tem-se como foco o direito das vítimas. Ocorre que, em Timor-Leste a escolha política do país em não exigir indenizações por parte da Indonésia, faz parte de um contexto mais amplo de não responsabilização do antigo estado invasor pelas violações de direitos humanos perpetradas. A escolha política de Timor-Leste, em não levar adiante nenhuma espécie de pedido de reparação, reflete claramente a priorização das relações econômicas e de uma opção pela não confrontação no plano geopolítico. Com efeito, a forte presença de empresas indonésias, os laços familiares entre timorenses e indonésios, bem como o desejo de participar do bloco regional da ASEAN, levou Timor-Leste a adotar o caminho da realpolitik, prejudicando assim também as pressões exercidas em favor das reparações devidas às vítimas.

A Indonésia, por sua vez, adotou postura aposta à de Timor-Leste, buscando reparações como consequência da perda de investimentos feitos em território timorense. ${ }^{175}$ O desfecho dessa demanda e a existência ou não de um acordo entre os dois países permanece uma pergunta em aberto.

Por fim, ainda no que concerne à responsabilidade por garantir as reparações, também sugiram inúmeras vozes atribuindo-a à comunidade internacional, por ter se omitido na questão de Timor-Leste, seja no período de dominação indonésia, seja no ano de 1999, no período do referendo. ${ }^{176}$ Nesse sentido, sustenta-se que Estados Unidos e Austrália, teriam uma responsabilidade coletiva, por terem apoiado a Indonésia durante a ocupação. Ademais, a ONU, ao atribuir a manutenção da segurança às tropas indonésias durante referendo, seria também responsável pelo massacre que ocorreu após a divulgação dos resultados, uma vez que tais ações por parte da Indonésia já eram previsíveis. A atribuição de responsabilidade política à comunidade internacional é defensável diante de todo o cenário geopolítico no qual está inserido o histórico de violações de direitos humanos que ocorreu em Timor-Leste, mas não se traduz em um dever de reparação e sim numa responsabilidade moral e numa dívida histórica para com o país.

O dever de reparação e sua implementação no caso de Timor-Leste, conforme demonstrado, revela-se ainda uma questão em aberto. Não restam dúvidas de que a

${ }^{175}$ BASSIOUNI, M. Cherif. International Criminal Court. Leiden: Martinus Nijhoff Publishers, $3^{\mathrm{a}}$ ed. 2008 , p. 265.

${ }^{176}$ Elizbeth Drexler faz uma análise critica da reponsabilidade da comunidade internacional e do fracasso da justiça internacional no caso de timor leste. DREXLER, Elisabeth. The Failure of International Justice in East Timor and Indonesia. In: HINTON, Alexadra Laban. Transitional Justice. London: Rutgers University Press, 2011, p. 49-66. 
responsabilidade por reparações reside primordialmente no estado indonésio, que entretanto, não tomou nenhuma iniciativa nesse sentido. Ademais, a comunidade internacional detém certo grau de responsabilidade moral pelos crimes cometidos, sobretudo dos principais apoiadores do regime de Suharto. Por outro lado, a responsabilidade de Timor-Leste em garantir o direito de reparação é um tema bastante controvertido. Mas, o certo é que, ainda que Timor-Leste não possa ser responsabilizado por reparar violações cometidas pelo estado indonésio, há uma percepção e também o reconhecimento público de que essas reparações são importantes para a coesão nacional. Nesse sentido, o debate em torno de uma política nacional de reparações permanece uma questão atual.

Outro importante debate diz respeito a quem são devidas essas reparações. Quando se fala em reparação, a principal preocupação no contexto transicional é a reparação devida às vítimas e violações de direitos humanos. Assim, podem ser devidas tanto às vítimas de forma individual, quanto à comunidades.

As reparações individuais dependem de algum mecanismo prévio objetivo que permita a identificação daqueles que irão receber o benefício. Isso pode gerar sentimentos de injustiça no seio da comunidade, uma vez que necessariamente implica uma seleção daqueles que irão receber a reparação exclusão de outros. Por outro lado, os mecanismos coletivos procuram endereçar as necessidades do grupo como um todo, por exemplo as mulheres ou crianças devido a sua vulnerabilidade. ${ }^{177}$ As reparações coletivas e individuais não são excludentes e podem ser conciliadas dependendo do contexto.

Em locais onde os laços comunitários são elementos formadores marcantes da cultura e da sociedade, como é o caso de Timor-Leste, uma abordagem coletiva às reparações pode revelar-se preferível, pois integra os valores culturais. Por outro lado, é também preciso reconhecer que, ao privilegiarem-se as reparações coletivas, é possível incidir no erro de promover novas formas de vitimização e opressão pelos indivíduos mais vulneráveis daquela comunidade. De sorte que, é desejável a busca por um balanceamento nessas relações, ao se configurarem as políticas de reparação.

Mas, em Timor-Leste não houve uma política ampla de reparações, apesar de algumas iniciativas pontuais. A CAVR, assim como a Comissão da Verdade e Amizade

\footnotetext{
${ }^{177}$ Para uma análise mais abrangente dos possíveis mecanismos de reparação consultar: MAGARRELL, Lisa. Reparations in Theory and Practice. New York: ICTJ, 2007. Disponível em: $<$ http://ictj.org/sites/default/files/ICTJ-Global-Reparations-Practice-2007-English.pdf $>$ Acesso em 20 de set de 2014.
} 
(CTF), fizeram recomendações no sentido de se estabelecer um projeto amplo de reparações. Entretanto, pouco foi feito nesse sentido, gerando um descontentamento por parte da população. Há uma percepção entre as vítimas de que a independência só foi possível com a sua contribuição, mas que seu papel e sua importância não foram devidamente reconhecidos após a independência. ${ }^{178}$ Com efeito, em Timor-Leste priorizou-se uma política em favor dos ex-combatentes em detrimento das vítimas de violações de direitos humanos. Ao dar-se tal enfoque perpetua-se o ciclo de negação dos direitos humanos das vítimas, em favor de uma lógica de hierarquia e ordem.

O terceiro aspecto a ser discutido sobre as reparações em Timor-Leste, diz respeito à formas de reparação. As reparações podem ser traduzidas em indenizações materiais ou em atos simbólicos de homenagem às vítimas. Essas formas de reparação não são substitutivas, e idealmente um programa de reparações abrange ambas as formas de reparação.

No que toca às reparações materiais foi instituído um programa de reparações urgentes, mas que teve um alcance bastante limitado. Ao identificar a necessidade premente que algumas vítimas tinham de fazer face aos custos de tratamentos médicos e psicológicos, a CAVR recomendou a criação desse programa. Nessa esteira, o Banco Mundial financiou o projeto, que inseriu as vítimas mais vulneráveis nas redes de proteção social, atribuindo-lhes um pagamento único no valor de US\$ 200,00. ${ }^{179}$ Entretanto, somente um pequeno número de vítimas beneficiou-se do programa, que também foi questionado por não estabelecer critérios claros de acesso às reparações. A iniciativa, não foi acompanhada por uma programa geral e compreensivo de reparações, apesar das recomendações da CAVR. Portanto, o alcance e efetividade do programa revelaram-se limitados.

Foi também prevista a criação de um fundo de reparação às vítimas, pelo Regulamento da UNTAET 15 de 2000, artigo 25, que estabeleceu os Painéis Especiais. O fundo, porém, jamais chegou a ser implementado. Além disso, existem ainda pagamentos específicos aos veteranos de guerra, executados pelo governo de Timor-Leste através do Ministério da Seguridade Social. Esse pagamentos, porém, não se tratam propriamente de reparações e sim de uma política de assistência social, uma vez que é atribuída em razão

${ }^{178}$ ICTJ. Unfulfilled Expectations: Victims' perceptions of justice and reparations in Timor-Leste. 2010. Disponível em: http://www.ictj.org/sites/default/files/ICTJ-TimorLeste-Unfulfilled-Expectations-2010English.pdf. Acesso em 05 de set de 2014.

${ }^{179}$ Idem. 
dos serviços prestados à nação na forma de resistência armada, não se estendendo às vítimas. Há, portanto, um enfoque diverso, e frequentemente criticado:

\begin{abstract}
[as vítimas] acreditam que as questões relativas aos veteranos na luta para alcançar a independência de Timor-Leste foram e continuam sendo priorizadas política e economicamente em relação aos problemas das vítimas, apesar da importância de seu papel na luta pela libertação. As vítimas acreditam que os veteranos apropriaram-se dos processos para obter reparações em seu próprio benefício econômico. ${ }^{180}$
\end{abstract}

A ausência, portanto de um programa de reparações materiais com foco nas vítimas tem gerado uma série de descontentamentos no seio da sociedade timorense. Em razão disso e buscando dar cumprimentos às recomendações da CAVR, em 2010 foi submetido à votação no Parlamento Nacional um projeto de reparações, que estabelecia também um instituto público da memória. O projeto previa reparações materiais e também reparações simbólicas, como atos de solenidade. Entretanto, as votações foram sucessivamente adiadas e o projeto não foi aprovado, restando ainda em aberto a formulação da política nacional de reparações.

Apesar da ausência de um projeto amplo de reparações, existem algumas iniciativas isoladas que de certa forma promoveram. Isso porque as reparações não se dão apenas em termos materiais. As reparações simbólicas também têm um importante papel de garantir o reconhecimento das vítimas, através de homenagens e solenidades.

Nesses termos, o panorama que se traça em Timor-Leste é mais positivo. Homenagens, entregas de medalhas, cerimônias e monumentos em homenagem às vítimas e combatentes fazem parte da realidade de Timor-Leste, por refletir as próprias tradições locais. O próprio trabalho da CAVR pode ser considerado uma forma de reparação. Sob tal prisma, a reparação simbólica, para além da esfera individual, também se presta à construção de uma identidade nacional. A sociedade timorense tradicionalmente valoriza as homenagens e cerimonias, o que favorece essas reparações simbólicas e a construção e de uma memória coletiva. Assim, mesmo que não haja um programa compreensivo de reparações, há - ainda que não intencionalmente - formas de reparações coletivas, homenageando comunidades e grupos familiares.

${ }^{180}$ ONU. Human Rights Council. Report of the Working Group on enforced or Involuntary Dissapearances Mission to Timor-Leste. A/HRC/19/58/Add.1, de 26 de dezembro de 2011, p. 11. 
Por outro lado, é importante também lembrar que a garantia de não repetição é uma das formas de reparação, reconhecidas pelos Princípios e Diretrizes sobre o Direito a Recurso e Reparação para Vítimas de Graves Violações do Direito Internacional dos Direitos Humanos e Graves Violações do Direito Internacional Humanitário. A garantia de não-repetição consiste justamente no controle civil das forças armadas, no fortalecimento do poder judiciário e mecanismos de prevenção de conflito. Existem inúmeras políticas nesse sentido, como por exemplo as iniciativas do Programa de Monitoramento de Justiça (Justice System Monitoring Programme - JSPM), do Programa das Nações Unidas para Desenvolvimento (UNDP), que acabam por realizar essa garantia de não repetição, ainda que não de forma sistematicamente organizada.

Em essência, a questão das reparações em Timor-Leste permanece como um desafio. Para tanto é necessário uma mudança de foco dos ex-combatentes para as vítimas, pois são elas a preocupação constante no debate dos direitos humanos. Ademais, o abandono das estruturas totalitárias exige uma mudança de paradigmas na relação entre estado e cidadãos, que só pode ser realizada através do empoderamento das vítimas da violência estatal.

\subsubsection{Reforma institucional}

O terceiro elemento da justiça de transição consiste na reforma institucional. $O$ estabelecimento da CAVR se insere nesse contexto de transformação das instituições. Sua idealização traduz a necessidade de estabelecer instituições democráticas, que reflitam a ruptura com o antigo sistema repressivo anterior. A CAVR, portanto, estabelece o elo de ligação entre o passado e os novo paradigma democrático. Assim, uma comissão a verdade é uma instituição temporária, mas cujos efeitos podem ser perpetuar para além de sua atuação. Suas contribuições devem assim ser considerados como um legado à história do país.

A relação entre a CAVR e a reforma institucional é uma questão mais complexa do que se mostra à primeira vista. Isso porque, a correlação existente entre reforma 
institucional e comissão da verdade não se trata necessariamente de uma relação causal. ${ }^{181}$ Em razão disso, é preciso tomar certo cuidado em atribuir este ou aquele efeito à CAVR sobre as instituições timorenses. O contexto de transformação institucional engloba inúmeros fatores, e atribuir a causa a apenas um deles seria desconsiderar o efeito dos demais. Por isso, a análise dessa relação entre reforma institucional e a CAVR deve ser cautelosa.

É possível afirmar que houve uma completa transformação das instituições em Timor-Leste após a retirada do vizinho ocupante. Não haveria de existir outra solução, diante do histórico do conflito. A libertação de Timor-Leste exigia uma reforma institucional completa, levada a diante pela ONU inicialmente e posteriormente conduzida pelo próprio governo timorense, a partir da restauração da independência em 2002.

Um reforma institucional implica a adequação das instâncias governamentais, legislativas e administrativas, bem como das próprias estruturas sociais, a partir de uma outra visão de estado. Instituições adequadas ao modelo de estado de direito exigem não apenas a realização de eleições e o respeito à vontade popular, consubstanciada no ato de votação, mas engendra em si outros importantes elementos como: segurança jurídica, proteção das minorias, limitações ao poder estatal e prestação de contas.

O fato é que cada vez torna-se evidente, a partir de estudos e análises empíricas, a relação entre governança, direitos humanos e desenvolvimento. Daí porque a proteção dos direitos humanos esteja associada às instituições democráticas. Nesse sentido, a realização dos direitos humanos depende de instituições que garantam o acesso à justiça, aos direitos econômicos, sociais, civis e políticos, bem como a proteção contra a arbitrariedade do poder estatal. Ao mesmo tempo, os direitos humanos se refletem em prestações estatais positivas, que informam o conceito de desenvolvimento. Desenvolvimento não se resume a um mero fator econômico, mas é composto por inúmeros outros elementos, como a redução de desigualdades sociais e a garantia de proteção aos grupos mais vulneráveis.

Amartya Sen traduz desenvolvimento como liberdade. Ou seja, desenvolvimento implica oferecer aos indivíduos escolhas verdadeiramente livres. Assim, é papel do estado garantir as condições mínimas econômica e sociais para que o sujeito se desenvolva e para que possa fazer suas escolhas. Portanto, o estado tem o dever de prestação positiva, ao

\footnotetext{
${ }^{181}$ A respeito dos efeitos e consequências da justiça de transição sobre a reforma institucional consultar: WIEBELHAUS-BRAHM, Eric. Truth Commissions and Transitional Societies - The Impact on Human Rights and Democracy. New York: Routledge, 2010.
} 
promover as condições necessárias ao exercício da liberdade e tem também um papel negativo, ao possibilitar a escolha individual. O reconhecimento de que o desenvolvimento é na verdade a liberdade real dos indivíduos, leva a uma relação complementar e dual entre desenvolvimento e direitos humanos.

Os laços informativos entres esses conceitos são inúmeros e complexos, daí a necessidade da multiplicidade de mecanismos de implementação. A coordenação e conjunção desses fatores para a construção do estado democrático de direito (state building) é ainda dificultada pelas limitações de ordem material e de recursos financeiros e humanos, que devem ser considerados no desenho dessas instituições. Com efeito, o desenvolvimento de instituições democráticas revela-se como um verdadeiro desafio em regiões de pós-conflito, onde as estruturas sociais e políticas anteriores foram desestabilizadas.

Mas, se por um lado associa-se a construção democrática com a realização de direitos humanos, por outro, há inúmeras críticas no sentido de que as reformas institucionais refletem ideais liberais forjados no seio da sociedade ocidental e que não são sensíveis às realidades locais. A idealização de um estado democrático de direito carrega consigo uma organização social baseado na participação popular, na tripartição de poderes e no respeito aos direitos humanos. Essas estruturas organizacionais, em alguns contextos podem trazer perplexidade às populações locais, por falta de compreensão de seu funcionamento.

Com efeito, em Timor-Leste a construção do estado de direito, em alguns aspectos, leva a um choque entre as estruturas forjadas em nome da democracia liberal e a cultura e organizações locais. Em Timor-Leste a sociedade está organizada em torno do vínculo familiar e da vila (suco). De maneira que a ideia de um estado democrático de direito, bem como todas as instituições que lhe dão suporte, é algo que ainda está por ser construído

Essa estrutura segmentada de Timor-Leste é característica também das outras ilhas próximas que compõem os estados da Melanésia. Fukoyama aponta que: "A sociedade melanésia é organizada em tribos, naquilo que os antropólogos chamam linhagens segmentares, grupos de pessoas que traçam a sua descendência a um ancestral 
comum ... A fragmentação social que existe na Melanésia é extraordinária". ${ }^{182}$ A sociedade segmentada que Fukoyama identifica, apoiado na teoria de Durkheim, caracteriza-se por sua autossuficiência. Ou seja, constituem-se grupos que isoladamente conseguem prover suas próprias necessidades. Essa forma de organização social também conta com seus mecanismos próprios de solução de disputas, onde a religião e o sagrado têm um papel central.

Conforma aponta Dionísio Babo-Soares, os elementos sagrados integram o nahe biti, como é conhecido o método local de solução de disputas. ${ }^{183}$ Essa sacralidade e vinculação dos métodos tradicionais de resolução dos conflitos com as crenças religiosas foi levada em conta pela CAVR, que aponta em seu relatório final:

Os participantes acreditam que os seus antepassados, invocados no início
da cerimônia, são testemunhas do ritual de nahe biti boot e validam os
procedimentos. A sua presença torna o processo vinculativo e acredita-se
que a recusa ou incumprimento das decisões acarreta consequências
graves. ${ }^{184}$

Os valores religiosos e seculares atuam de maneira sincrética, permeando toda a sociedade timorense e naturalmente influenciando também os mecanismos de solução de disputas. A visão mística, portanto, que caracteriza a sociedade timorense, também acaba por influenciar o desenvolvimento das instituições democráticas, ainda que não formalmente. Assim, por exemplo a estrutura familiar e em torno da vila, também permanecem em novas formas na prática institucional, mesmo quando em aparente contradição com os ideais de um estado de direito. Portanto, os laços comunais de hierarquia e obediência são transportados para a esfera estatal.

De maneira que são gerados alguns pontos de fricção entre as instituições democráticas que refletem o ideal liberal de estado e as práticas locais, bem como a herança deixada pelo autoritarismo indonésio. Essa diferentes visões de mundo podem gerar atritos políticos e sociais quando não são bem compreendidas e gerenciadas.

\footnotetext{
182 "Melanesian society is organized tribally, into what anthropologists call segmental lineages, groups of people who trace their descendent to a common ancestor...The social fragmentation that exists in Melanesia is extraordininary". FUKUYAMA, Francis. The Origins of Political Order. London: Profile Books, 2012. p. Xii, tradução livre.

183 SOARES, Dionísio Babo. Nahe Biti: The Philosophy and Process of Grassroots Reconciliation (and Justice) in East Timor.In: The Asia Pacific Journal of Anthropology.vol.5, n.1, abril, 2004, p. 31.

${ }^{184}$ CAVR. Relatório Chega! Capítulo 9, 2005, p. 05.
} 
Entender esses aspectos da realidade local é essencial para a análise da reforma institucional, bem como do trabalho e dos resultados produzidos pela CAVR.

Apesar das fricções entre a cultura local e os ideais democráticos e mesmo considerando os obstáculos de ordem material e de capital humano, o que se vê em Timor Leste é um engajamento nacional no sentido de implementar um estado operante e que seja capaz de afirmar sua soberania nacional e internacional. A necessidade de se firmar perante a ordem internacional, como um estado democrático e que é capaz de prover as necessidades de sua população, é reflexo de toda a história de dominação que Timor-Leste sofreu e do papel central exercido pela comunidade internacional na conquista da autodeterminação.

Com a saída da última missão da ONU para Timor Leste em dezembro de 2012, pugna-se pela inauguração de uma nova fase na história do país. Não mais uma fase de pós-conflito, mas uma fase de desenvolvimento, pensamento que se reflete no conhecido slogan: "adeus conflito, bem vindo desenvolvimento". Assim, o verdadeiro obstáculo, de acordo com essa visão, não é mais o fim do conflito, pois este já teria sido superado, e sim o avanço de um estado capaz de prover as necessidade materiais de seu povo. Há uma ênfase, portanto, na efetivação de direitos econômicos e sociais.

Entretanto, é necessário estar atento às heranças deixadas pelo autoritarismo, que permanecem latentes e por vezes podem passar desapercebidas. Não se pode olvidar que, além de se submeter ao regime ditatorial indonésio por vinte quatro anos, Timor-Leste também esteve sob o comando do regime Salazarista de Portugal, desde 1920. Portanto, somam-se mais de sete décadas sob o comando de regimes autoritários. Diante dessa herança é preciso constantemente realizar um exercício de reflexão e de retomada do passado, a fim de se evitar o ressurgimento de novas ondas de autoritarismo, que afetam sobremaneira os direitos civis e individuais. Os regimes autoritários também trazem consequências gravosas aos direitos econômicos e sociais, como se viu com as grandes fomes que ocorreram em Timor-Leste, durante a dominação indonésia. Entretanto, a tensão entre autoritarismo e direitos civis e políticos revela-se ainda mais espinhosa. Assim, é necessário alertar para que na atual conjuntura política de Timor-Leste não se reproduzam as estruturas autoritárias, que tendem a dar maior ênfase aos direitos econômicos e sociais em detrimento dos direitos civis e políticos.

Nesse sentido, cumpre lembrar que o regime militar indonésio sustentou-se por longas décadas apoiado no discurso de segurança social, da realização de direitos 
econômicos e da estabilidade. Ao prover as necessidades básicas de alimentação, todos os demais direitos, sobretudo a liberdade de expressão e pensamento afiguravam-se meramente secundários. Por isso, ao se priorizar novamente a realização desses direitos, que se configuram na prestação positiva de ordem material, não se pode relevar a necessidade de realização das liberdades individuais, sob o risco do ressurgimento de novos elementos do autoritarismo. Outro importante fator de análise a respeito do desenvolvimento das novas instituições, consiste na estrutura social hierarquizada e a reverência às autoridades (ema bot), que caracterizam a sociedade timorense.

De maneira que a herança histórica e aspectos socioculturais da sociedade timorense implicam a necessidade de se promover uma mudança de mentalidade, a fim de garantir uma efetiva participação popular e um estado que respeite os direitos humanos e as minorias. Para que se evite o ressurgimento de novas formas de autoritarismo é imperioso que se edifiquem instituições democráticas sustentáveis e que sejam capazes de dialogar com a população. É preciso, portanto, superar-se o idealismo com que muitas vezes são projetadas tais instituições, levando a um descolamento da realidade e à inefetividade.

Nesse sentido, o relatório Chega! e os demais materiais produzidos pela CAVR, servem como uma plataforma de referência para análise dos elementos do autoritarismo e das violações de direitos humanos praticadas em nome do estado. Constitui-se um importante material no estabelecimento de uma memória coletiva, na educação para direitos humanos, bem como para a elaboração e políticas públicas e instituições democráticas. Ocorre que, com o fim do mandato da CAVR, seu trabalho nem sempre é analisado sob o viés da memória e da garantia de não-repetição. Nesse sentido, é preciso notar que até hoje o Parlamento Nacional não deu seguimento à recomendação da CAVR para estabelecer uma política nacional de reparações, adiando sucessivamente as votações sine dia. Assim, embora o trabalho da CAVR tenha sido encerrado em termos operacionais, o legado que deixa não deve ser esquecido, ao contrário: deve integrar a reforma das instituições do país.

Com efeito, alguns dos desafios institucionais identificados pelo relatório da CAVR permanecem. A consolidação de um estado de direito, que respeite os direitos humanos e minorias encontra-se ainda em construção, uma vez que exige não apenas a elaboração de uma legislação adequada, mas também da formação humanística dos cidadãos, para que possam ser capazes de participar ativamente das decisões políticas e da operacionalização das instituições. Nesse diapasão, a construção de um estado democrático 
de direito compreende não só a realização de eleições periódicas e transparentes, mas depende de outros importantes elementos, que em Timor-Leste ainda estão sendo edificados. Esse processo depende igualmente de recursos financeiros e capital humano, a fim de que possa ser reformulada a relação entre os cidadãos e o estado.

Em relação às necessidade econômicas para o financiamento do desenvolvimento institucional, cumpre frisar que Timor-Leste é fortemente dependente do petróleo, sendo seu principal produto e fonte de $90 \%$ da receita estatal. Disso resulta uma necessidade de boa administração do recurso, considerando as necessidades atuais e futuras do país. ${ }^{185}$ Resulta igualmente em um crescente apelo pela diversificação da economia, buscando diminuir a dependência em um único recurso não renovável. Se por um lado, o petróleo permite que o país tenha recursos suficientes para financiar seu desenvolvimento, por outro também impõe o desafio de superar o paradoxo da abundância, com que muitos países ricos em recursos petrolíferos têm se deparado, uma vez que a riqueza mineral não se traduziu em benefícios efetivos aos cidadãos, ampliando apenas as disparidades sociais. Diante dessa realidade, a reforma institucional necessária e consequente da instalação do regime democrático, deve ainda fornecer estruturas que possam fazer frente à administração desse recurso natural, garantindo que se traduza em benefícios concretos à população.

Portanto, a reforma democrática no período pós-conflito, não se resume à criação de instituições que permitam o livre exercício dos direitos políticos, mas também que possibilitem a participação e o controle popular na administração dos recursos financeiros do país, que deve levar em conta as necessidades sociais. Mecanismos anticorrupção, como a Comissão Anticorrupção de Timor-Leste (CAC) são, portanto, cruciais no contexto da reforma institucional.

Além do suporte financeiro necessário ao desenvolvimento das instituições democráticas, há também a necessidade de se fortalecer o capital humano e construir capacidades (capacity building). Consciente desse desafio, Timor-Leste busca parcerias na forma de cooperação internacional e no apoio de organizações internacionais, que fornecem treinamento e transferência de conhecimento. A dificuldade no desenvolvimento do capital humano é consequência direta do histórico dos conflitos, do legado autoritário e da apropriação do estado pelo regime militar indonésio.

${ }^{185}$ Para garantir maior eficiência na utilização dos recursos foi criado o Fundo Petrolífero de Timor-Leste, através da lei $n^{\circ} 9$, de 2005 . 
Primeiramente, o longo período de conflito levou a uma natural reformulação das prioridades de cada indivíduo, cuja principal preocupação passou a ser a sobrevivência, colocando outras necessidades em um plano secundário. Em segundo lugar, Timor-Leste sofreu com grandes períodos de fome coletiva e hoje a desnutrição ainda constitui-se enorme desafio, impactando portanto na capacidade de aprendizagem e de qualificação da mão de obra. Em terceiro lugar, o sucateamento de educação em Timor-Leste fazia parte de uma política estatal durante o período indonésio, uma vez que a preparação de uma massa populacional consciente e questionadora seria contrário aos interesses do regime, em uma área que reivindicava a libertação.

Por fim, a dificuldade em desenvolver as capacidades e o capital humano também se deve à política do kerkayaan, implementada durante o período de dominação da Indonésia. Durante esse período, mesmo os órgãos administrativos eram ocupados por militares. Essa penetração militar em todos os níveis institucionais caracterizava o kerkayaan. Justificava-se pela necessidade de implementar os projetos do governo e superar a alegada incompetência dos civis. ${ }^{186}$ Essa monopolização na gestão e a execução dos projetos pelos militares, impediu a formação de uma mão de obra capaz de gerir as instituições estatais.

Esse bloqueio à participação civil levou a um enorme desafio na construção das instituições timorenses no pós-independência. Assim, havia uma ausência de mão de obra suficientemente preparada para conduzir as atividades de estado, já que os timorenses eram impedidos de participar de maneira efetiva e concreta nas instituições públicas, durante o tempo da ocupação. De maneira que os desafios atualmente vividos no tocante às reformas institucionais, se devem também em grande medida a esse fator.

A reformulação das instituições no caso de Timor-Leste passa não apenas pela capacitação dos cidadãos no sentido técnico, mas pela construção de um vínculo de identidade. Assim, a valorização da resistência e de construção da identidade nacional são elementos centrais para o sucesso dessas políticas. Nesse sentido a CAVR tem um importante papel, de narração da história e de construção de um passado comum. Assim, ao retratar as histórias individuais permite a identificação de experiências comuns. Além disso, deixa um legado no sentido de não retrocesso, ao afirmar de maneira simbólica que o autoritarismo não pode mais ser aceito no seio das instituições estatais.

${ }^{186}$ HONNA, Jun. Military Politics and Democratization in Indonesia. London: Routledge, 2005, p. 8. 
A garantia da não repetição leva à reflexão acerca do modelo institucional democrático adotado por Timor-Leste no pós-independência. Por isso, sustenta-se neste trabalho a necessidade de não se adotar somente um discurso desenvolvimentista no contexto timorense. É preciso, ter em conta ainda a realidade pós-conflito e o ciclo de violência experienciado pela sociedade timorense. As fragilidades institucionais ainda não foram superadas e ainda afiguram-se como um problema de primeira ordem, que para ser solucionado depende de uma mudança de percepção. A estabilidade das instituições democráticas e a segurança jurídica são valores que não podem ser avaliados sob o impulso do imediatismo. Assim, é necessário construir-se uma base institucional sólida que forneça estabilidade ao país, ao mesmo tempo em que se promove uma mudança de concepção sobre o papel do estado.

Nesse sentido, a CAVR presta uma colaboração significativa para a construção e estabilidade de instituições democráticas. O modo de solucionar controvérsias, adotado pela CAVR, assim como a realização das audiências públicas refletem e ao mesmo tempo informam a própria estrutura do novo paradigma democrático. Assim, ao se permitir a participação das vítimas, há uma valorização do indivíduo e de suas experiências, ao se colocar o abuso do poder estatal como prática inaceitável.

A CAVR, portanto, mais do que o papel que lhe é atribuído quando de sua criação no sentido de investigar as violações de direitos humanos, representa uma ponte entre realidades distintas e entre sujeitos. Ademais, inaugura uma nova forma de pensar as instituições estatais. Há uma relação de confluência entre comissão da verdade e reforma institucional, pois uma fortalece e alimenta a outra. Comissões da verdade, tal como a CAVR servem como base na edificação dos estados democráticos, que emergem do pósconflito.

O relatório Chega! mantém-se atual quase uma década depois, uma vez que suas recomendações e o material produzido ainda são um ponto referencial para o desenvolvimento das instituições e da política nacionais. O material também permite verificar que alguns dos desafios apontados devem ainda ser superados. Dentre as recomendações do relatório final aponta-se, por exemplo, para a necessidade de se desenvolver um poder judiciário independente e que garanta a efetividade dos direitos humanos: 
É essencial dispor de um sistema judicial independente e operacional para garantir a existência do Estado de direito em Timor-Leste. Durante a ocupação indonésia, o sistema judicial estava seriamente viciado. A independência do sistema judiciário face à política governamental foi comprometida e o sistema judicial não foi capaz de proteger os direitos humanos fundamentais dos acusados através da instrução correta do processo. Ao atuar desta forma, deu um contributo substancial para a cultura de impunidade vigente, e para o desrespeito pelo Estado de direito, sendo em si mesmo causa de violações dos direitos humanos. ${ }^{187}$

As recomendações do relatório permitem que se analise em retrospecto os avanços e dificuldades encontradas na construção de um judiciário independente, instituição essencial na construção democrática. As observações realizados pela CAVR mantem-se atuais, na medida em que ainda existem grandes desafios no setor da justiça, por exemplo. Nesse sentido, estudiosos e analistas apontam que:

\begin{abstract}
A debilitada capacidade do sistema judiciário timorense foi agravado pela interferência política que reforçou a impunidade e comprometeu o Estado de direito, especialmente em relação ao setor público e de segurança. Comutações presidenciais de condenações, anistias, promoções, e a nomeações de envolvidos em crimes graves são alguns dos exemplos mais claros dessa interferência política. ${ }^{188}$
\end{abstract}

Verifica-se, portanto, que muitas das questões enfrentadas no relatório Chega! de 2005, permanecem atuais e retratam os desafios ainda a ser vencidos na construção do estado democrático. Com efeito, a superação do paradigma do autoritarismo, deve estar acompanhada não apenas de reformas idealizadas em termos teóricos, mas de uma mudança de concepção e cultura. De maneira que a CAVR deixa não apenas um legado fatual, de registro histórico, mas deixa também um marco de construção de espaços democráticos e de participação popular, bem como referências institucionais e recomendações a serem implementadas.

\footnotetext{
${ }^{187}$ CAVR. Relatório Chega! Recomendações 5.3, 2005.

188 The weak capacity of the Timorese judiciary has been compounded by political interference that has reinforced impunity and undermined the rule of law, especially in relation to the government and security sector. Presidential commutations of sentences, proposed amnesties and promotions, and appointments for those involved in serious crimes are some of the clearest examples of this political interference ICTJ. Country case study: Timor-Leste - Security Sector Reform in Timor-Leste.2009. Disponível em: $<$ https://www.ictj.org/sites/default/files/ICTJ-IFP-TimorLeste-Security-Reform-2009-English.pdf $>\quad$ Acesso em: 29.11.2014.
} 


\subsubsection{As comissões da verdade: CAVR e CTF}

A justiça de transição foi aqui caracterizada por quatro elementos, sendo um deles o principal interesse desse estudo: as comissões da verdade. A fato de terem sido instaladas duas comissões da verdade no contexto transicional timorense, sendo uma de caráter nacional e outra de caráter bilateral imprime maior riqueza à análise do papel das comissões da verdade, permitindo identificar aspectos comuns e dissonantes nos trabalhos de cada um delas. Tanto a CAVR quanto a CTF foram encarregadas de apurar as violações de direitos humanos ocorridas, mas os trabalhos de cada uma delas foi essencialmente diverso. A forma de apuração da verdade e o próprio conceito de verdade que foi incorporado, foram substancialmente distintos.

Primeiramente, o mandato da CAVR abrangia o período compreendido entre abril de 1974 a outubro de 1999. Já a CTF foi encarregada apenas de apurar os fatos ocorridos em 1999, relacionados ao referendo realizado em 30 de agosto do mesmo ano. A limitação temporal do mandato de cada uma das duas comissões é ilustrativa do posicionamento político de cada um dos dois países em relação ao conflito. Com efeito, a Indonésia sempre considerou os acontecimentos ocorridos em Timor-Leste durante a ocupação como uma questão de segurança interna e não sob o prisma dos direitos humanos. Assim, não havia qualquer motivação para que efetivamente se investigassem os fatos ocorridos durante os anos de ocupação.

A CAVR foi um projeto desenvolvido pelo governo de Timor-Leste em conjunto com a ONU, mas não contou com a colaboração da Indonésia, apesar de as principais violações de direitos humanos terem ocorrido sob o regime de ocupação da Indonésia, num contexto de violações sistemáticas cometidas em nome desse estado. Essa observação é ao mesmo tempo sintomática e informativa da atividade estatal e dos princípios que norteiam a organização de cada um desses estados. Assim, os trabalhos da CAVR devem ser analisados tendo em vista essa contextualização que, por si só, demonstra o nível de comprometimento de cada um dos países na realização dos direitos humanos.

A CTF foi composta por um igual número de comissários de cada país, buscando assim, uma maior legitimidade. Em razão da limitação temporal do mandato da CTF, o relatório final apenas contextualizou o conflito durante a ocupação, na medida do necessário para a identificação das causas da violência de 1999. Os trabalhos da CTF 
iniciaram-se no mesmo ano em que a CAVR concluiu seus trabalhos, em $2005 .{ }^{189}$ Sua criação foi vista como uma tentativa de reavaliar as informações trazidas pela CAVR, numa busca por estabelecer a versão final dos fatos. O relatório final da CTF foi concluído em 31 de dezembro de 2008 e intitulado Per memorium Ad Spem (da memória à esperança).

O estabelecimento da CTF foi, para muito analistas, uma reação da Indonésia aos trabalhos da CAVR numa tentativa de amenizar ou reinterpretar os fatos relatados. A CTF foi mandatada para estabelecer a verdade conclusiva dos fatos envolvendo os acontecimentos de 1999. De acordo com o relatório final: "Apesar termos trabalhado com base nos termos de referência, utilizando o termo "akhir kerenaran"190, não temos a intenção de apresentar os resultados da comissão como absolutos. Acreditamos que a única verdade absoluta é aquela que pertence a Deus". ${ }^{191}$

Assim, o próprio conceito de verdade adotado pelo relatório difere do conceito de verdade factual. O direito à verdade consiste no conhecimento dos fatos e não se confunde com interpretação ou opinião. $\mathrm{O}$ conhecimento da verdade é direito coletivo e individual que consiste em ter acesso à informação e ao reconhecimento de violações. Portanto, difere da verdade enquanto revelação divina ou mesmo da interpretação dado pelas partes. Ao contrário do que estabelece o relatório não se trata de estabelecer uma única interpretação dos fatos, mas sim de trazer os acontecimento ao conhecimento público e da admissão pelo estado das violações cometidas.

Há, portanto, uma diferença terminológica e conceitual na verdade buscada pelos trabalhos a CTF e o conceito de direito à verdade. À CTF, assim como à CAVR, foi atribuída a responsabilidade de apurar a verdade e reconhecer as violações de direitos humanos. Mas, os termos em que essa apuração se deu são conceitualmente diversos e tem reflexos práticos no estabelecimento da verdade. A própria limitação temporal do mandato já evidencia esse recorte diferenciado que a CTF adotou.

Por outro lado, enquanto a CAVR caracterizou-se por uma abordagem comunitária, envolvendo a população local e ouvindo as diferentes vozes, a CTF

\footnotetext{
${ }^{189}$ A CTF iniciou seus trabalhos em 11 de agosto de 2005.

${ }^{190} \mathrm{O}$ termo equivalente em língua portuguesa corresponde à "verdade final"

191 "Although we worked based on the Terms of Reference by using the term "kerenaranakhir", we do not intend to place the commission's findings as absolute. We put that on the realization that the only truth is one that belongs to God". CTF. Per Memoriam Ad Spem - Final Report.2008, p. V, tradução livre. Disponível em: <http://www.cja.org/downloads/Per-Memoriam-Ad-Spem-Final-Reeport-of-the-Commission-of-Truthand-Friendship-IndonesiaTimor-Leste.pdf> Acesso em: 07.09.2014.
} 
caracterizou-se muito mais por uma aproximação das relações entre o estado indonésio e timorense, o que torna-se evidente no relatório final: "Essas recomendações visam realizar um registro histórico compartilhado que possa formar a base para um futuro pacífico e próspero para as duas nações". ${ }^{192}$ Com efeito, apesar de ambas as comissões se ocuparem da investigação dos fatos envolvendo as violações de direitos humanos, tiveram abordagens metodológicas e prioridades e objetivos distintos.

$\mathrm{Na}$ CAVR as vítimas tiveram um papel central, enquanto que o trabalho da CTF teve como foco a análise documental produzida pelas instituições transicionais que a antecederam: os Painéis Especiais, a CAVR, o Tribunal Ad hoc de Jakarta e a KPP-HAM. A CTF ouviu algumas vítimas e testemunhas, porém o foco de seu trabalho consistiu na análise dos documentos já produzidos pelas instituições anteriores. Portanto, a CTF procurou aparar as arestas que despontaram a partir das interpretações dissonantes do conflito adotadas em cada um dos dois países. Consistiu, portanto, em uma tentativa de reconciliação de políticas de estado.

Diante dessa abordagem da CTF é pertinente trazer ao debate dois aspectos: primeiramente, as funções de uma comissão da verdade e em segundo lugar o papel das vítimas na apuração da verdade. As funções de uma comissão da verdade são variáveis em razão dos objetivos estabelecidos e dos demais fatores envolvendo o contexto de transição. Assim, não existe uma padrão a ser seguido, mas em geral as comissões da verdade terão entre seus objetivos a apuração dos fatos, afinal uma comissão da verdade que não se preocupa em revelar os fatos, perde sua razon d'etre. Assim como os objetivos, as metodologias para apuração da verdade também podem ser variáveis. Devem, porém estar claras quais as opções metodológicas realizadas, bem como as limitações na investigação e apuração dos fatos. Nesse sentido, a CTF se propôs a analisar a documentação já produzida por outras instituições transicionais. Caracteriza-se, portanto, como uma metodologia de revisão. Os relatos de vítimas e testemunhas tinham por função apenas corroborar ou infirmar os fatos elucidados nos documentos produzidos anteriormente. Assim, a CTF não vem trazer à luz nenhum fato novo e sim realizar uma compilação e interpretação dos trabalhos anteriores.

\footnotetext{
192، These recommendations aim at realizing shared historical record that can form the basis for a peaceful and prosperous future for the two nations". CTF. Per Memoriam Ad Spem - Final Report.2008, p. V, tradução livre. Disponível em: <http://www.cja.org/downloads/Per-Memoriam-Ad-Spem-Final-Reeport-ofthe-Commission-of-Truth-and-Friendship-IndonesiaTimor-Leste.pdf $>$ Acesso em: 07.09.2014.
} 
Cumpre nesse aspecto retomar as lições de Paul Ricoeur que afirma que ao se consultar um arquivo há sempre uma projeção de explicação, ou seja uma hipótese de compreensão. ${ }^{193}$ Com efeito, a análise da documentação parte de uma visão de mundo, em busca de uma explicação, de uma satisfação. No caso da CTF, os documentos consultados eram os mesmos que foram objeto de estudo da CAVR, dos Painéis Especiais, do Tribunal Ad Hoc e da KPP-HAM. Porém, o olhar lançado pela CTF era completamente diferente, na medida em que constituiu-se como instituição bilateral e ao mesmo tempo destituída de qualquer pretensão de responsabilização criminal. Essa inovação, no sentido de estabelecer uma comissão mista sinalizou esforços reconciliatórios na trajetória da política de estado dos dois países, mas colocou a questão das violações e o papel das vítimas em segundo plano.

Portanto, em que pese denominação de comissão da verdade atribuída à CTF, sustenta-se que sua natureza é essencialmente diversa, o que não implica uma inutilização do seu trabalho. Mas, imprime-lhe uma outra função. A CTF, por sua constituição, mandato e objetivos afigurou-se muito mais como um fórum de aproximação nas relações entre Timor-Leste e Indonésia, aparando arestas e procurando conformar as visões do conflito, ao mesmo tempo servindo como uma afirmação política no sentido de que os estados envidariam esforços para manutenção de uma relação de cooperação.

O trabalho da CTF veio assim, interpretar esses acontecimentos de 1999 e garantir o pronunciamento oficial do estado Indonésia e do estado de Timor-Leste. Portanto ao reconhecer a existência de violações, o relatório Per Memorium ad Spem vem de certa forma contribui para o reconhecimento da verdade:

\begin{abstract}
A Comissão concluiu que as provas demonstram que o funcionários da TNI e polícia, bem como funcionários civis, eram, por vezes, envolvidos em praticamente todas as fases dessas atividades que resultaram em graves violações de direitos humanos, incluindo homicídio, estupro, tortura, detenção ilegal e outros sérias privações de liberdade física, e transferência forçada e deportação. Esse tipo de atividade sistemática e coordenada, envolvendo muitas formas de apoio, incentivo, e co-autoria é a base para a conclusão da Comissão de que a TNI, a Polri e governo civil, todos têm a responsabilidade institucional por esses crimes. ${ }^{194}$
\end{abstract}

\footnotetext{
${ }^{193}$ RICOEUR, Paul. A memória, a história, o esquecimento. Campinas: Editora Unicamp, 2007.

194 "The Commission concluded that the evidence demonstrated that the TNI and Police personnel, as well as civilian officials, were at times involved in virtually every phase of these activities that resulted in gross human rights violations including murder, rape, torture, illegal detention and other severe deprivation of
} 
O reconhecimento de que os crimes cometidos em 1999, na verdade resultaram de uma política sistematizada institucional, surpreendeu as expectativas de analistas e ONGs. Nesse sentido, o relatório também contribui para o avanço dos direitos humanos, superando a política do negacionismo. O relatório final e a atuação da CTF tiveram um alcance limitado, tanto pelo mandato, quando pelos recursos e pelas contingências políticas, entretanto, o reconhecimento das violações no relatório deve ser aplaudido. $\mathrm{Na}$ sequencia da submissão do relatório, o então presidente da Indonésia Susilo Bambang Yudhoyono reconheceu oficialmente pela primeira vez as violações de direitos humanos praticadas em Timor-Leste pelas instituições estatais. ${ }^{195}$

A Indonésia, até os dias de hoje, no âmbito doméstico se depara com o conflito de interesses entre os militares e os anseios da nova democracia. Assim, a posição o país em relação aos crimes cometido em Timor-Leste reflete as contradições da própria identidade indonésia e suas tensões internas. Portanto, o reconhecimento das violações no relatório deve ser encarado de maneira positiva e ao mesmo tempo pode se tornar um importante instrumento na preservação e avanço dos direitos humanos em ambos os países. Apesar da passagem dos anos sem que boa parte das recomendações tenham sido implementadas, o trabalho da CTF serve como referencial para a educação em direitos humanos e para o debate público tão caro às democracias.

A CAVR, por seu turno, contou com características bastante distintas, tanto em termos de mandato, como no que se refere aos recursos, metodologia e prioridades. Apesar da CTF também dedicar-se à apuração da verdade, o trabalho da CAVR foi muito mais abrangente, permitindo uma maior participação das vítimas e executando um trabalho de investigação bastante complexo, a fim de revelar os crimes cometidos durante todo o empo do conflito. Com a política da terra arrasada e a queima de documentos após a retirada indonésia, o trabalho da CAVR iniciou-se efetivamente do marco zero. Assim, para revelar os crimes e sistematizar as informações foi preciso um trabalho envolvendo um grande

\footnotetext{
physical liberty, and forcible transfer and deportation. This kind of sustained and coordinated activity involving many forms of support, encouragement, and co-perpetration forms the basis for the Commission's conclusion that the TNI, Polri and civilian government all bear the institutional responsibility for these crimes". CTF. Per Memoriam Ad Spem - Final Report.2008, p. 292, tradução livre. Disponível em: $<$ http:/www.cja.org/downloads/Per-Memoriam-Ad-Spem-Final-Reeport-of-the-Commission-of-Truth-andFriendship-IndonesiaTimor-Leste.pdf> Acesso em: 07.09.2014.

${ }^{195}$ HIRST, Megan. An Unfinished Truth: An Analysis of The Commission of Truth and Friendship's Final Report on the 1999 Atrocities in East Timor.ICTJ. 2009. Disponível em: $<$ http://ictj.org/publication/unfinished-truth-analysis-commission-truth-and-friendships-final-report-1999atrocities> Acesso em: 02.11.2014.
} 
número de audiências, consultas às testemunhas, vítimas e também perpetradores. Essa metodologia de trabalho, fez com que toda a comunidade fosse envolvida e consequentemente se relacionasse de alguma forma aos trabalhos e ao relatório final.

\subsection{A CAVR}

O trabalho de apuração e de reconhecimento da verdade levado a cabo pela CAVR foi influenciado por uma série de fatores externos que devem ser levados em consideração na análise dos resultados. Assim, a implementação do direito à verdade e as dificuldades dela advindas só podem ser compreendidas a partir de uma análise integradora. O reconhecimento do direito à verdade representa um avanço na concepção de direitos humanos, mas deve traduzir-se em sua efetivação. Nesse sentido, a análise dos trabalhos da CAVR pode ser de alguma contribuição ao estudo do direito à verdade.

A CAVR refletiu, não apenas um processo de justiça transicional, mas também um projeto de construção de um novo estado, que para isso precisava lidar com um passado de graves violações de direitos humanos. Ao mesmo tempo em que possuía um viés institucional democrático, também contribuiu para o esclarecimento de violações de direitos humanos. Na qualidade de comissão da verdade, à CAVR coube múltiplas funções, dentre as quais a tarefa de investigar e revelar a verdade, garantindo o conhecimento e o reconhecimento oficial da verdade. Promoveu ainda a reconciliação nacional e teve um importante papel na construção da identidade timorense.

A CAVR foi elogiada por observadores internacionais e representado como um caso de sucesso. Priscilla Hayner aponta a CAVR com uma das cinco comissões da verdade mais efetivas, ao lado das comissões que se instalaram na África do Sul, Peru, Guatemala e Marrocos. ${ }^{196}$ Com efeito, a CAVR conseguiu desenvolver um trabalho compreensivo, que envolveu a participação de toda a sociedade timorense em diversos níveis e regiões. Entretanto, a CAVR não é apenas uma lição de sucesso. Suas deficiências também servem como exemplos das dificuldades que podem emergir na instituição de uma comissão da verdade. Podem ser mencionados assim os desafios de implementação das recomendações como um dos um dos principais entraves. Nesse sentido é possível citar as recomendações no sentido do afastamento de pessoas envolvidas em violações de direitos

${ }^{196}$ HEYNER.Priscilla. Unspeakable Truths. New York: Routledge, $2^{\mathrm{a}}$ ed, 2002. 
humanos das forcas de segurança, bem como as recomendações de promoção do dever de reparação e da responsabilização criminal, que até hoje não foram alcançados.

A CAVR não foi criada com o intuído de estabelecer uma verdade dos vencedores e sim de documentar as violações, independentemente da posição política dos agentes. Assim seu mandato abrangeu o período compreendido entre abril de 1974 a outubro de 1999, incluindo portanto em sua competência o conflito interno, que antecedeu a invasão indonésia. Assim, o relatório endereça não apenas as violações praticadas pela Indonésia, que constituíam a maior parte delas, mas também os crimes cometidos pelos agentes da resistência e pela milícias que recebiam o apoio da Indonésia.

No contexto de Timor-Leste essa diferenciação das violações em razão da posição política adotada pelo sujeito, seria impraticável e ao mesmo tempo teria efeitos deterioradores sobre a tão frágil unidade nacional. Primeiramente porque a sociedade timorense já encontrava-se cingida, antes mesmo da invasão. Isso porquê o período que antecedeu a invasão indonésia, foi também marcado por um conflito armado interno. Assim, não foram apenas os militares indonésios que cometeram violações de direitos humanos, pois os próprios timorenses dividiam-se em seu apoio à anexação da indonésia, recorrendo também à violência, mortes e desaparecimentos forçados.

Em segundo lugar, porque o antagonismo entre os apoiadores do regime indonésio e aqueles que defendiam a independência penetrou no seio da sociedade civil durante todo o período de ocupação. A espionagem e o disfarce foram amplamente utilizado por ambos os lados do conflito com a finalidade obter informações sobre o opositor. Assim, identificar a posição individual adotada em apoio a um ou outro lado seria extremamente problemático devido a esse jogo de informantes infiltrados em ambos os lados e portanto, não poderia servir como critério para o exercício da competência da CAVR. Com efeito, um mesmo indivíduo poderia se encontrar na qualidade de vítima e de perpetrador, dado o alto grau de envolvimento da sociedade civil e ao prolongado período de conflito. Além disso, os civis também eram recrutados à força pelos comandantes da tropas indonésias, através da Operasi Kikis, fenômeno que ocorreu sobretudo em 1981. A respeito das violações investigadas pela CAVR, aponta no relatório Chega!:

Geralmente, o contexto das violações em massa, que é o objeto do inquérito ou investigação duma comissão, envolve tanto os intervenientes estatais, como militares e agentes da polícia e do governo, como também elementos de grupos de oposição, de partidos políticos, de milícias, de grupos empresariais e outros indivíduos. Um relato da "verdade" relativa 
a um conflito será incompleto se não incluir as ações de todos estes intervenientes. ${ }^{197}$

Portanto, o mandato da CAVR se dirigiu à investigação da violações de direitos humanos independentemente da posição política dos autores e das vítimas. Ademais, limitar o mandato da CAVR às violações cometidas pelos indonésios apenas serviria para dividir ainda mais a sociedade timorense, uma vez que houve uma alta miscigenação entre timorenses e indonésios. ${ }^{198}$ Assim, qualquer espécie de polarização poderia levar ao aumento de tensões. Além disso, o dever de proteção e respeito aos direitos humanos aplicam-se a ambos os lados do conflito, uma vez que as obrigações de direitos humanos incidem sobre todos independentemente da posição política adotada. Tratam-se de normas horizontais que impõem obrigações não somente aos estados, mas também aos indivíduos, ainda que na qualidade de combatentes ou civis.

Não obstante, quando as violações de direitos humanos integram uma política de estado, essa violações adquirem outra dimensão pois passam a ser instrumento do autoritarismo. Nesse sentido, o trabalho da CAVR abrangeu não somente a identificação de violações de direitos humanos, dos sujeitos e vítimas envolvidos, mas também a identificação de uma política sistematizada de crimes contra a humanidade. Aponta, por exemplo, que: "os membros das forças de segurança indonésias e os seus auxiliares cometeram e consentiram execuções extrajudiciais e desaparecimentos forçados de maneira generalizada e sistemática durante o período de ocupação indonésia de TimorLeste". ${ }^{199}$ Portanto, o mandato da CAVR se debruçou sobre as violações individuais, mas também se preocupou em delinear um enquadramento geral do período compreendido entre abril de 1974 e outubro de 1999.

Conforme apontado pela CAVR em seu relatório final, a verdade para ser completa e fiel aos fatos deve ser apurada independentemente da posição política da vítima e do perpetrador. Nesse sentido, é preciso evitar os perigos da meia verdade, sob pena de contrariar o próprio conteúdo do direito à verdade, que não se traduz em uma reinvenção

\footnotetext{
${ }^{197}$ CAVR. Relatório Chega! Capítulo2, 2005, p. 4.

198 A miscigenação entre timorenses e indonésios, ocorreu em razão de dois fatores, precipuamente: o casamento entre miliares indonésios e timorenses e a utilização do estupro como tática de guerra e ocupação, com a finalidade de tornar indonésia a população de Timor-Leste.

${ }^{199}$ CAVR. Relatório Chega! Subcapítulo 7.2: Mortes Ilícitas e Desaparecimentos Forçados, 2005, p. 325.
} 
da história e sim na apuração, revelação e reconhecimento dos fatos. ${ }^{200}$ Portanto, a CAVR traçou as violações cometidas por ambos os lados, identificando padrões sistematizados de violações.

Para que a CAVR pudesse exercer suas funções, logo após a promulgação o regulamento UNTAET 10 de 2001, que deu origem à CAVR, foi criado um gabinete temporário, até que se escolhessem os comissários nacionais e regionais. A organização da CAVR compreendia um conselho consultivo que apoiava os trabalhos dos oito comissários nacionais. ${ }^{201}$ A designação de comissários regionais permitiu a aproximação entre a CAVR e as comunidades, que foi crucial para o bom desenvolvimento dos trabalhos e a realização dos objetivos da CAVR.

Com efeito, os trabalhos da CAVR foram orientados por uma abordagem integrada com foco na comunidade. Ademais, outro importante instrumento de aproximação entre os trabalhos da CAVR e as comunidades foi o programa de rádio, transmitido semanalmente, chamado Caminho para a Paz (Dalan ba Dame). Assim, criouse uma elo de comunicação importante entre os trabalhos a nível nacional e as comunidades ao longo de todo o território do país. ${ }^{202}$ A ênfase no processo comunitário e em integrar as regiões remotas no processo de construção dos trabalhos da CAVR foi uma marca caracterizadora da comissão e um elemento chave para sua legitimidade.

A comissão iniciou seus trabalhos em 7 de abril 2002, deparando-se com enormes desafios logísticos. Além da falta de infraestrutura, havia também a questão do idioma, uma vez que Timor-Leste é marcado pelo multilinguíssimo, o que afigurou-se como um desafio para a redação final do relatório. Ainda do ponto de vista organizacional, foram elaborados três projetos pilotos para que se pudesse determinar as dificuldades e o método

\footnotetext{
${ }^{200}$ A esse respeito cumpre notar, que de acordo com as conclusões da CAVR, a resistência foi responsável por cerca de $26 \%$ das mortes e desaparecimentos forçados relatados. CAVR, Relatório Chega! Subcapitulo 7.2: Mortes Ilícitas e Desaparecimentos Forçados, 2005, p. 317.

${ }^{201}$ A comissão foi presidida por Aniceto Guterres Lopes e o vice-presidente escolhido foi o Padre Jovito Rego de Jesus Araújo. A comissão contava com outros sete membros: Maria Olandina Isabel Caeiro Alves, Jacinto das Neves Raimundo, Jose Estevão Soares, Agostinho dos Vasconcelos, Jacinto da Neves Raimundo Alves e Isabel Amaral Guterres

${ }^{202}$ Nesse sentido, cumpre retomar a discussão a respeito do avanço dos direitos humanos e dos novos meios de comunicação. O rádio, a televisão e tiveram um papel crucial na conquista da independência de TimorLeste. Internamente a comunicação entre os membros da resistência era feito através de rádios ,que permitia a coordenação e organização logística. Posteriormente, sobretudo com a visita do Papa João Paulo II e o massacre de Santa Cruz, a divulgação de imagens e informações sobre timor na mídia internacional, foram cruciais para o sucesso da frente diplomática e para chamar a atenção da comunidade internacional à causa timorense. Posteriormente, após a independência, o advento da internet imprimiu um novo significado ao desenvolvimento das comunidades em Timor-Leste e à atuação de organizações de direitos humanos.
} 
a ser empregado. ${ }^{203}$ Também foi elaborado um plano, que previu uma equipe multidisciplinar, formada por mais de 270 pessoas, distribuídas em todo o país.

Os principais programas implementados pela CAVR consistiram: no apuramento da verdade, em audiências públicas e das vítimas, nos processos de reconciliação comunitária (PRC) e no acolhimento e apoio às vítimas. ${ }^{204}$ Para que fosse possível documentar as violações e apurar a verdade, a CAVR recolheu mais de sete mil testemunhos, promoveu investigações e audiências públicas. A CAVR também entrevistou autoridades e requisitou documentos de partes estrangeiras.

Conforme apontado, a participação da comunidade internacional foi decisiva tanto para a independência de Timor-Leste quanto para a manutenção do regime indonésio, durante os 24 anos de ocupação. Nesse sentido, as informações aprestadas por outros países, eram de grande relevância para incremento dos trabalhos. Ainda, de acordo com os Princípios para Proteção e Promoção dos Direitos Humanos através de Ações de Combate à Impunidade, é dever dos estados colaborar com a comunicação e restituição de arquivos relevantes ao apuramento da verdade. ${ }^{205}$ Apesar do dever de colaboração, nenhuma resposta oficial dos outros estados foi encaminhada à CAVR. Ainda sim, representantes locais de alguns países procuraram auxiliar a CAVR nesse sentido. Inúmeras pessoas e organizações contribuíram com o fornecimento de documentos, que tiveram um papel fundamental na investigação e sistematização dos dados.

Inicialmente a Comissão foi instituída para um mandato de 24 meses, mas esse período se estendeu, de maneira que operou efetivamente por 42 meses e culminou na apresentação do relatório Chega! em 2005. O relatório foi divulgado por uma equipe de campanha que percorreu os distritos em 2004, sensibilizando a população e partilhando as informações que seriam inseridas no relatório final. Ademais, para garantir que o relatório fosse acessível foi publicado em tetum, português, inglês e indonésio. Com a finalização

${ }^{203} \mathrm{O}$ primeiro projeto piloto consistiu em um processo de recolha de testemunhos na ilha de Atauro. O segundo projeto piloto foram os seminários promovidos em Dili, com o objetivo de traçar o perfil das comunidades. Já o terceiro projeto piloto traduziu-se em uma audiência de reconciliação com a presença de vitimas, perpetradores, membros da comunidade, o procurador geral e os comissários nacionais.

${ }^{204}$ Para executar esses programas a CAVR foi organizada em seis divisões: apuramento da verdade, acolhimento e apoio à vítima, reconciliação comunitária, apoio a programas, administração e logística e finanças. Posteriormente foi criada uma equipe de Arquivo e Comarca, encarregada da preservação do arquivos.

205 "Principle 18. Specific Measures related to the restoration o for transition to democracy and/or Peace (c) Third countries shall be expected to cooperate with a view to communicating or restituting archives for the purpose of establishing the truth."

ONU. Commission on Human Rights. Promotion and Protection of Human Rights. Report of the Independent Expert to Update the Set of Principles to Combat Impunity, Diane Orientlicher - Updated Set of principles for the protection and promotion E/CN.4/2005/102/Add.1, de 8.02.2005. 
dos trabalhos e o fim da comissão em dezembro de 2005, foi criado um pós-secretariado encarregado de promover a disseminação dos trabalhos da CAVR, bem como de concluir a edição, cuidar dos arquivos e manter o patrimônio da CAVR. Atualmente o antigo presídio de Balide, onde a CAVR tinha sua sede abriga uma biblioteca e arquivos sobre a comissão.

\subsubsection{Objetivos e resultados da CAVR}

O relatório final constitui um legado da CAVR para a posteridade. Foi o maior esforço de documentação empreendido em Timor-Leste e permitiu que se conhecesse a história do país e os elementos formadores da identidade nacional. A CAVR foi encarregada de um mandato amplo, que criou enormes expectativas em relação aos resultados que poderia oferecer. Encontravam-se entre seus objetivos: apurar a verdade, promover a reconciliação, reintegrar indivíduos, reestabelecer a dignidade humana, colaborar com o procurador geral e promover os direitos humanos.

Diante dessa amplitude de finalidades é difícil avaliar todos os resultados efetivamente alcançados. Essa dificuldade de avaliação é devida, não somente, à amplitude dos objetivos estabelecidos, mas à própria ausência de parâmetros objetivos e quantificáveis de avaliação. A influência de fatores externos em relação a esses objetivos também constitui outro óbice para encontrar medidores adequados de avaliação. Conforme assinala Eric Wiebelhaus-Brahm:

Apesar da crescente popularidade das comissões de verdade, nossa
compreensão do seu impacto nas sociedades pós-conflito é limitada por
vários fatores. Primeiramente, embora a literatura sobre comissões de
verdade ofereça várias pistas a respeito de seus efeitos esperados, a
maioria das medidas que foram sugeridas são difíceis de definir e
observar empiricamente. Essas complicações tornaram mais fácil aos
observadores apoiar-se em julgamentos normativos. Em segundo lugar, a
cadeia causal entre comissão da verdade e o desfecho de interesse
raramente é traçado com o cuidado necessário. ${ }^{206}$

206 "Despite the growing popularity of truth commissions, our understanding of their impact on post-conflict societies is limited by several factors. First, while the literature on truth commissions does provide several clues regarding their expected effects, most of the measures that have been suggested are difficult to define and observe empirically. These complications have made it easier for observers to rely on normative judgments. Second, seldom is a casual chain between truth commission and the outcome of interest carefully traced." WIEBELHAUS-BRAHM, Eric. Truth commissions and Transitional Societies - The Impact on Human Rights and Democracy. New York: Routledge, 2010, p. 22. 
Com efeito, é preciso haver certo cuidado ao avaliar o impacto e os efeitos produzidos por uma comissão da verdade. Priscilla Heyner adota posicionamento semelhante ao afirmar que: "é muito mais difícil medir alguns dos outros efeitos esperados seguindo-se o mesmo modelo estatístico. Também é difícil assegurar que todas as diferenças contextuais sejam consideradas ao se realizarem essas comparações e conclusões. ${ }^{207}$ Portanto, primeiramente é necessário reduzir expectativas, uma vez que as comissões da verdade sozinhas não resolvem todos os desafios transicionais. Daí, porque ser necessário compreender sua relação com os demais elementos como responsabilização, reparação e reforma institucional. Cada um desses elementos tem um enfoque diferenciado ao mesmo tempo em que dialoga com o trabalho das comissões da verdade, de forma sinérgica.

Em segundo lugar, é necessário também avaliar os trabalhos da CAVR tendo em vista suas contingências. Assim, as limitações de ordem material, temporal e de recursos humanos não podem ser ignoradas. Conforme assinala Eduardo Gonzalez: "para que os objetivos de uma comissão da verdade sejam alcançados é necessário encontrar um balanço entre a comissão que se revela necessária e a comissão que se mostra possível". ${ }^{208}$ Em terceiro lugar, é preciso direcionar o estudo no sentido de avaliar cuidadosamente cada um dos objetivos propostos em sua totalidade. Avaliar os trabalhos de uma comissão da verdade apenas de forma abrangente, mas não com a necessária profundidade, pode levar a conclusões equivocadas.

Por isso, é necessário debruçar-se individualmente sobre cada um dos objetivos para saber se e em que medida foram atendidas as finalidades a que se propôs. Os objetivos da CAVR foram traçados pelo Regulamento 2001/10:

Artigo $3^{\circ}$
Objetivos e Funções da Comissão
3.1 Os objetivos da Comissão incluirão o seguinte:

(a) conduzir inquéritos sobre violações de direitos humanos que tenham ocorrido no quadro dos conflitos políticos de Timor-Leste;

\footnotetext{
207 "It is much harder to measure some of the other hoped-for effects in the same statistical manner. It is also difficult to ensure that all of the many different contextual issues are taken on board in making these comparisons and conclusions". HEYNER.Priscilla. Unspeakable Truths. New York: Routledge, $2^{\mathrm{a}} \mathrm{ed}, 2002$, p. 26, tradução livre.

${ }^{208}$ GONZÁLES, Eduardo. Set to fail? Assessing tendencies in Truth Commissions Created after Violent Conflict. In: ICTJ. Challenging the Conventional: Can truth Commissions Strengthen Peace Processes? Jun 2014, p.9, tradução livre. Disponível em: <http://www.ictj.org/publication/challenging-conventional-cantruth-commissions-strengthen-peace-processes> Acesso em: 06.12.2014.
} 
(b) estabelecer a verdade em relação às violações de direitos humanos cometidos no passado;

(c) relatar a natureza das violações de direitos humanos que tenham ocorrido e identificar os fatores que possam ter conduzido ao cometimento de tais violações;

(d) identificar as práticas e políticas, quer sejam de atores do Estado ou não do Estado, que necessitem de ser abordadas para prevenir futuras ocorrências de violações de direitos humanos;

(e) encaminhar os casos de violações de direitos humanos ao Gabinete do Procurador Geral com recomendações no sentido do processamento dos autores das ofensas sempre que julgado apropriado;

(f) assistir no restabelecimento da dignidade humana das vítimas;

(g) promover a reconciliação;

(h) apoiar a recepção e reintegração de indivíduos que tenham causado danos às suas comunidades através do cometimento de pequenas ofensas criminais e de outros atos prejudiciais por meio da simplificação de mecanismos de reconciliação baseados na comunidade; e

(i) promover os direitos humanos.

Há, portanto, um objetivo geral de promoção dos direitos humanos, que se desdobra no dever de promover a verdade, relatando a natureza das violações e práticas institucionais, através da condução de inquéritos e investigação. Ademais, prevê-se um dever de colaboração com a esfera da responsabilização criminal, garantida pela necessidade de encaminhamento dos casos ao Procurador Geral. Outros objetivos especificamente delineados são o reestabelecimento da dignidade das vítimas e a reconciliação, na qual se insere o dever de promover a recepção e reintegração dos antigos perpetradores.

Esses objetivos se entrelaçam levando a um delicado balanço entre cada uma das finalidades. A multiplicidade de objetivos pode naturalmente levar a que se privilegie um dos enfoques, levando a uma perda de espaço em relação aos demais, de maneira proporcionalmente inversa. Jon Elster aponta que, em alguns casos, é necessário realizar uma escolha entre justiça e verdade. ${ }^{209}$ Isso porque, o receio de punição pode levar, por exemplo à não revelação por completo dos fatos. Por outro lado, essas influências podem ser positivas, na medida em que o sucesso de uma, implique em um beneficiamento dos demais objetivos.

A condução dos inquéritos, por exemplo, permite que estabeleça a verdade em relação às violações ocorridas. Através do trabalho de investigação emerge a verdade factual, a revelação dos acontecimentos, que culminou na apresentação do relatório final.

${ }^{209}$ ELSTER, Jon. Closing the books - transitional justice in historical perspective. Cambridge: Cambridge University Press, 2004. 
Apurar a verdade significa contextualizar os abusos e identificar as sistemáticas utilizadas. É necessário igualmente identificar-se as pessoas e instituições envolvidas, os fatores internos e externos, bem como a responsabilidade política pelas violações. Algumas das práticas identificadas foram o desaparecimento forçado, execuções sumárias, deslocamento forçado e fome, bem como tortura, maus tratos e prisões arbitrarias. Além disso, o relatório faz um extensa descrição dos julgamentos políticos e da violência sexual.

Ao relatar os desaparecimentos forçados e mortes, a CAVR também identificou os massacres, considerando como tal o homicídio de cinco ou mais pessoas indefesas e marcadas como alvo. Descreve assim alguns dos capítulos mais funestos na história de Timor-Leste, como o massacre de Kraras, de agosto de 1983, o massacre de Santa Cruz, de 12 de novembro de 1991 e o massacre da igreja de Suai em setembro de 1999. O relatório, conclui portanto, que a os massacres não retratavam acontecimentos isolados, mas estavam inseridos em uma política sistematizada de violações de direitos humanos.

As mortes e desaparecimentos forçados fizeram sobretudo vítimas do sexo masculino, em idade adulta. Entretanto, as mulheres também sofreram outros abusos, como a violência sexual. Assim, o relatório dedica uma seção específica à violência sexual, da qual a maior parte das vítimas eram do sexo feminino. São relatados casos de tortura e escravidão sexual, assim como outras formas de violência sexual. Para além da violência infligida à vítima, tratava-se de uma política de humilhação da comunidade:

\begin{abstract}
A dimensão e a natureza das violações demonstram que a intenção subjacente ia para além da gratificação pessoal dos perpetradores ou do impacto direto em cada uma das vítimas. O propósito continha uma tentativa de humilhar e de desumanizar o povo de Timor-Leste. Foi uma tentativa clara de destruir a sua vontade de resistir, de reforçar o facto de que eles eram totalmente impotentes e sujeitos a qualquer capricho cruel e desumano que pudesse brotar nas mentes daqueles que controlavam a situação pela força das armas. Os oficiais militares insistiam em tratar e falar com as vítimas timorenses como se estas fossem "sub-humanas". Estes padrões ajudaram a disseminar esta mentalidade entre todas as forças de segurança, contribuindo para uma justificação mais fácil e uma participação mais generalizada nas violações sexuais. ${ }^{210}$
\end{abstract}

Ao identificar as práticas adotadas pelas forças de segurança indonésias, bem como as violações perpetradas por membros da resistência, a CAVR garante o cumprimento da obrigação do estado em assegurar o direito à verdade, permitindo que se

${ }^{210}$ CAVR. Relatório Chega! Sub-Capítulo 7.7, 2005, p. 120. 
tome conhecimento a respeito dos fatos ocorridos. Mas, a busca da verdade na maior parte das vezes não constitui um objetivo explícito nos mandatos das comissões da verdade, mas o qual deve ser inferido de uma leitura interpretativa. Com efeito, importantes comissões, como a Comissão da Verdade e Reconciliação da África do Sul e a Comissão da Verdade do Peru, contemporânea à CAVR, não preveem expressamente a busca da verdade em seu mandato. Outro exemplo, é a da Comissão Nacional da Verdade, no Brasil, estabelecida em 2011, que tampouco prevê expressamente o estabelecimento da verdade, como um objetivo. Diferentemente, a CAVR prevê a busca da verdade de maneira explícita em seus objetivos. Nesse sentido o relatório final aponta para a necessidade de se valorizar a verdade em torno dos fatos:

Divergências contínuas e a negação de fatos históricos impedem os
diferentes lados de um conflito de encontrar uma base comum para iniciar
o processo doloroso, difícil e lento da reconciliação. As atividades de
apuramento da verdade tinham por objetivo criar uma história dos
acontecimentos baseada em informação objetiva e não em rumores ou
propaganda. Por sua vez, uma versão solidamente fundada da verdade
poderia, abrir caminho à admissão de responsabilidade e viabilizar a
aceitação e o perdão.

O estabelecimento das verdades fatuais coexiste com outros objetivos a serem alcançados pelas comissões da verdade, como a reconciliação e o combate à impunidade. O dever de encaminhar os caso de grave violações ao Procurador Geral e o dever de colaboração asseguraram que a CAVR não fosse instrumentalizada a favor da impunidade. De fato, esse disposição corrobora a afirmação de que os mecanismos de justiça de transição coexistem e operam de forma complementar e não substitutiva. Nesse sentido, o direito à verdade não é um único bem a ser protegido, pois se insere em um âmbito mais abrangente de combate à impunidade, que também se procurou assegurar através do regulamento que instituiu a comissão.

No caso da CAVR, a relação entre a apuração da verdade, e a necessidade de encaminhamento dos casos à procuradoria geral, levou a um aparente antagonismo, já que alguns perpetradores temiam admitir o ocorrido, pois a depender da gravidade poderia darse início a um processo perante os Painéis Especiais. A apresentação perante os PRCs era um ato estritamente voluntário. Portanto, é impossível determinar quantas pessoas

${ }^{211}$ Idem. Introdução, p. 35. 
deixaram de apresentar-se por ter esse receio. ${ }^{212}$ Entretanto, uma análise holística dos trabalhos da CAVR permite concluir que os PRCs tiveram grande êxito, pois foram realizadas 217 audiências de reconciliação e concluídos 1381 processos de PRCs.

Os PRCs, ao promoverem a reconciliação comunitária, permitiram a recepção e reintegração de indivíduos que causaram danos às suas comunidades. Simultaneamente contribuíram também para o restabelecimento da dignidade humana das vítimas ao integrarem-nas no processo reconciliatório. Os PRCs além de promoverem a reconciliação comunitária, contribuíram também para a apuração da verdade, na medida em que exigiam o esclarecimento dos fatos e circunstâncias por parte dos perpetradores. Assim, foi possível conciliar o objetivo de combate à impunidade com a apuração da verdade. Conforme apontado pelo relatório final:

\begin{abstract}
Apesar do objetivo formal das audiências ser o de permitir aos depoentes serem readmitidos nas suas comunidades, através da exposição da verdade e da realização de "atos de reconciliação", na verdade, a troca de informação entre os depoentes e os restantes participantes produziu, frequentemente, uma versão completa e precisa dos acontecimentos, o que beneficiou toda a comunidade. ${ }^{213}$
\end{abstract}

Portanto, os PRCs também permitiram a apuração da verdade, apesar da necessidade de remeter as informações ao Procurador Geral. A integração dos trabalhos entre os diversos mecanismos da justiça de transição permite a criação de condições necessárias à responsabilização. Assim, a aparente dualidade existente entre comissões e o a necessidade de combater a impunidade pôde ser superada a partir de uma visão complementar. Isso porque, a partir da relação entre a CAVR e os Painéis Especiais, forjou-se um processo integrado e holístico, diferenciando aqueles que praticaram pequenos delitos, daqueles que causaram danos maior, assim compreendidas as graves violações de direitos humanos. A relação entre CAVR e os Painéis Especiais foi essencial para evitar que a comissão prejudicasse o elemento da responsabilização no contexto da justiça de transição. Embora a apuração da verdade seja um importante fator, não tem supremacia sobre os demais, razão pela qual é necessário compreender a justiça de transição enquanto um todo sistêmico.

212 “O direito da Procuradoria-Geral em aceder a toda a informação prestada à Comissão traduziu-se na impossibilidade de garantir às potenciais testemunhas que as suas provas e declarações não seriam usadas contra elas próprias em procedimentos judiciais futuros...Esta disposição poderá ter impedido a Comissão de aceder a informação importante que poderia ter auxiliado a sua função de apuramento da verdade" CAVR. Relatório Chega! Capítulo 02, 2005, p. 7.

${ }^{213}$ Idem. Reconciliação Comunitária, p. 44. 
A superação do antagonismo entre justiça e verdade deve ter em conta que o direito à verdade, para que seja efetivado deve ser interpretado a partir da unicidade dos direitos humanos. Portanto, não pode prevalecer como direito absoluto diante dos demais diretos compreendidos no processo transicional. O direito à verdade deve servir como uma elevação das garantias e não como bem absoluto a ser protegido. Assim, a garantia à não impunidade e a responsabilização devem ser considerados também como fatores determinantes na implementação do direito à verdade.

Os processos de apuração da verdade e de reconciliação devem ser guiados pelo reestabelecimento da dignidade humana, que pode ser conduzido de diversas formas. Por um lado, o reconhecimento das violações praticadas, a prestação de contas e a admissão dos fatos pelo estado reformulam a relação entre vítimas, perpetradores e estado. Essa admissão na esfera pública dos crimes cometido permite que as vítimas tenham reconhecido seu sofrimento e a injustiça e violência a que foram expostos. Com efeito, a própria vítima tem plena consciência dos abusos a que foi submetida, mas o reconhecimento público é uma espécie de satisfação. Ao refletir sobre o processo de reconciliação na África do Sul, Edson Teles assinala: “Ao tomarem para si a condição de sujeitos políticos, as vítimas são beneficiadas não por um agir terapêutico, mas ao serem empoderadas por um processo público que concorre para a instauração de sua dignidade e reparação de seu sofrimento",214

O reconhecimento público dos crimes, porém, por si só não esgota a necessidade de se garantir o reestabelecimento dessa dignidade. Nesse sentido, as reparações tem um importantíssimo papel a fim de permitir, tanto quanto possível, oferecer condições às vítimas para que possam recompor-se do trauma sofrido, em termos psicológicos, físicos e econômicos. Infelizmente no caso de Timor-Leste a questão das reparações é um capítulo ainda em aberto, apesar das recomendações realizadas pela CAVR.

A reconciliação integra a ideia de recepção e reintegração dos indivíduos responsáveis pelos crimes cometidos. Mas, o significado de reconciliação pode variar e ser interpretado de maneiras diversas. Para o ICTJ, a reconciliação deve ser um projeto social

${ }^{214}$ TELES, Edson. Brasil e África do Sul: os paradoxos da democracia. Memória política em democracias com herança autoritária. Tese (Doutorado em Direito) - Faculdade de Direito, Universidade de São Paulo, São Paulo, 2010, p. 97. 
de longo prazo, e que não se esgota na comissão. ${ }^{215} \mathrm{O}$ processo de reconciliação requer sobretudo o envolvimento dos indivíduos e a ampla discussão pública.

No caso da CAVR, para compreender o significado de reconciliação, cumpre remeter ao primeiro Congresso Nacional do CNRT, de onde se originou a ideia de estabelecer uma comissão da verdade. No pronunciamento, esclarece-se que por reconciliação entende-se o reconhecimento de erros do passado, bem como arrependimento e perdão. Subjacente está a ideia de incluir a população, de maneira a romper o ciclo de acusações. Por fim finaliza afirmado que não se trata apenas de um processo de resolução de conflitos, mas "um processo do qual deva resultar a verdade". 216 Portanto, a reconciliação pressupõe o reconhecimento das violações, a revelação da verdade.

O reconhecimento da verdade é o pressuposto necessário para que se dê início a qualquer processo de reconciliação. É a base para a reaproximação das relações. Para um processo de reconciliação é imprescindível que se tenha o mesmo ponto de partida: a verdade factual, ou seja a violência originária daquela circunstância. A ruptura na relação ocorre no momento de violência que caracterizou o encontro entre vítima e perpetrador. Ao mesmo tempo em que inflige humilhação à vítima é, por isso mesmo também, o ponto de partida para a reestruturação da relação.

Sob essa perspectiva de reestruturação da relação e ressignificação dos papéis, a reconciliação toma como base a existência de alguma relação anterior ao ato de violência. Por isso, falar em reconciliação entre sujeitos que não tenham tido qualquer vínculo anterior ou posterior ao evento que levou a vítima à essa condição, parece inapropriado. Isso porque a reconciliação pressupõe o reestabelecimento de um consenso, de um entendimento mútuo. Mas, estabelecer novamente uma relação que jamais existiu e que tampouco tem o propósito de ser futuramente é um contrassenso.

Nesse sentido, reconciliação não se confunde com perdão. Embora possam existir simultaneamente, não há uma completa correspondência de termos. A reconciliação pressupõe uma relação passada e leva a uma relação futura. O perdão, ao contrário, não pressupõe essa relação prolongada no tempo - remete apenas ao ato de violência, sem qualquer pretensão de reestabelecer alguma relação. Para Jacques Derrida o verdadeiro perdão é somente aquele incondicional, que independente da atitude do culpado. ${ }^{217} \mathrm{O}$

\footnotetext{
${ }^{215}$ ICTJ. Disponível em: <http://ictj.org/in-search-of-truth/> Acesso em: 01.06.2013.

${ }^{216}$ CAVR. Relatório Chega! Capítulo 1, 2005, p.11.

${ }^{217}$ DERRIDA, Jacques. On Cosmopolitanism and Forgiveness. New York : Routledge, 2006.
} 
perdão resulta da esfera íntima da vítima. A reconciliação, ao contrário implica o reestabelecimento da relação. Há uma espécie de compartilhamento de impressões entre vítima e perpetrador, com a finalidade de garantir uma coexistência pacífica futura. Nesse sentido, a reconciliação difere do perdão pois não é incondicional. A reconciliação pressupõe o envolvimento do ofensor e uma mudança de posicionamento. Já o verdadeiro perdão, não depende dessa troca, é apenas um ato voluntário e incondicional da vítima. Mas, perdão, assim como a reconciliação, encerra o ciclo de violência, ao interromper o curso dos acontecimentos. ${ }^{218}$

Para Jacques Derrida é preciso distinguir o perdão de seus falsos irmãos. O poder de interrupção do perdão e da reconciliação, portanto, não podem ser confundidos com a interrupção que se dá em razão da anistia e da prescritibilidade. Conforma assinala Cláudia Perrone-Moisés, o perdão para Jacques Derrida impõe uma visão ética. ${ }^{219}$ Se tomarmos essa visão como ponto de partida é possível identificar a diferença de natureza entre perdão e reconciliação e anistia e prescritibilidade. O perdão e a reconciliação estão insculpidos em uma moral, que Derrida retrata como moral judaico cristã e nada tem a ver com aspectos jurídicos.

A anistia e a prescritibildiade são institutos jurídicos, criações doutrinarias, encampadas pelos ordenamentos jurídicos ocidentais, como reflexo de uma política criminal. Assim, a anistia e a prescritibilidade, tal como a coisa julgada, provocam uma domesticação do tempo, mas não necessariamente põem fim ao conflito subjacente. Nesse ponto a diferença entre os institutos do perdão e da reconciliação e da anistia e prescritibilidade afloram. Apenas o dois primeiros tem o condão de por fim ao conflito subjacente. Os dois últimos não necessariamente levam ao fim da situação antagônica, apenas blindam os perpetradores das consequências jurídicas de seus atos criminosos, mas não promovem uma reintegração ou uma pacificação social.

As proposições de Jacques Derrida acerca da origem do perdão e seu fundamento judaico-cristão permitem compreender porque nas línguas originárias de Timor-Leste inexiste o termo correspondente ao perdão. Com efeito, a noção de perdão se traduz pelo vocábulo de origem portuguesa desculpa ou perdoa. ${ }^{220}$ Sob esse ponto de vista, identificase facilmente a distinção entre perdão e reconciliação. Os mecanismos de reconciliação

\footnotetext{
${ }^{218}$ PERRONE-MOISÉS. O perdão e os crimes contra a humanidade: um diálogo entre Hannah Arendt e Jacques Derrida. In: CORREIA, Adriano (Org). Hannah Arendt e a condição humana. Quarteto, p. 216. ${ }^{219}$ Idem.

${ }^{220}$ COSTA, Luis. Palestra proferida em maio de 2009, Lisboa.
} 
encontram-se presentes na cultura de Timor-Leste e permitem a recomposição das relações da comunidade, mas exigem uma contrapartida do ofensor ou de sua família. Por outro lado, o tema do perdão é introduzido a partir da ética cristã, incorporada com a colonização portuguesa.

Ao se adentrar a discussão a respeito do perdão e reconciliação é inevitável questionar o fenômeno das anistias nos contextos transicionais. Trata-se de uma questão polêmica, muitas vezes retratada como o suporte necessário ao fim do regime anterior. Por outro lado, a anistia além de ferir o direito das vítimas ao remédio efetivo, contribui para perpetuação do ciclo de impunidade, que tipicamente caracteriza um sistema que se utiliza de violações de direitos humanos para sua manutenção. As anistias e o instituto da prescritibilidade impõem um ponto final às violações apenas sob o aspecto da sanção jurídica, que ainda sim pode ser questionado tendo em vista a natureza das violações de direitos humanos. No caso de Timor-Leste não houve a anistia oficial dos perpetradores. Entretanto, a omissão da Indonésia na responsabilização pelos crimes cometidos durante a ocupação impôs uma anistia silenciosa.

A reconciliação, assim como perdão, parte de um outro enfoque: a quebra do ciclo de violência. $\mathrm{O}$ sentido de reconciliação pode ser compreendido em termos individuais, comunitários ou nacionais. A reconciliação individual toma por base relação entre vítima e perpetrador. A esse respeito assinala, Jina More que esperar a reconciliação com o ofensor, é na verdade impor mais um fardo à vítima. ${ }^{221}$ Nesse sentido, a reconciliação não pode ser um processo necessário, mas deve constituir um processo voluntário, baseado no desejo de recomposição de ambas as partes.

Surge então a pergunta do porquê a vítima buscaria uma reconciliação com seu perpetrador e vice-versa. Ora, conforme apontado, a reconciliação só torna-se significativa quando presente algum tipo de relação anterior ao ato de violação e quando simultaneamente há perspectivas de relação futura. Do contrário, uma reconciliação perde sua própria essência. Partindo-se dessa premissa é de se compreender que seja do interesse da vítima e do perpetrador garantir uma coexistência pacífica e a estabilidade das relações, sem que se tenha o medo de uma retomada no ciclo de violências. Além disso, o ato de reconciliação permite que a vítima se desvencilhe a partir de então de sua posição de vítima, e que o perpetrador também abandone seu papel de seu algoz. Essa

${ }^{221}$ MORE, Jina. Truth Commissions. In: Issues in Peace and Conflict Studies. Thousand Oaks: Sage, p. 317340 . 
descaracterização é especialmente importante em sociedades onde o vínculo comunitário se sobressai em relação às sociedades baseadas em princípios individualistas. Assim, nas sociedades segmentadas, onde a comunidade se sobrepõe ao indivíduo, essa reconciliação entre sujeitos permite também a reconciliação entre famílias. Portanto, a reconciliação ao nível das relações individuais também se reflete nas demais relações existentes no seio dessa comunidade.

Sob esse prisma, os PRCs refletem processos de reconciliação entre indivíduos e entre indivíduos e a comunidade. Conforme apontado, os mecanismos de justiça tradicional, incorporados nos PRCs, partem de um paradigma de justiça coletiva, na qual o papel do indivíduo na comunidade se sobressaí em relação à lógica individualista. Nesse sentido, os trabalhos da CAVR foram extremamente frutíferos.

\begin{abstract}
De acordo com os participantes, o programa do PRC contribuiu significativamente para a reconciliação ao nível individual, da aldeia e da povoação. Disponibilizou um fórum no qual os indivíduos puderam expressar convicções e emoções anteriormente reprimidas, partilhar rancores e arrependimento, e decidir deixar o passado de violência para trás. O conflito político gerou um legado de desconfiança e ressentimento sentido em todos os escalões da sociedade timorense. Ao proporcionar às comunidades a oportunidade de reanalisarem acontecimentos históricos, o PRC ajudou a deslindar a teia de suspeitas que tinham, de facto, impedido a reconciliação. ${ }^{222}$
\end{abstract}

Por isso, os PRCs trouxeram consequências positivas no sentido de possibilitar a reconciliação individual e comunitária. Os resultados desse processos de reconciliação só podem ser efetivamente analisados a longo prazo e se tomados dados concretos a respeito dos índices de violência de cada comunidade que tenha experienciado o processo dos PRCs. Ao considerar o alto valor atribuído aos rituais sagrados e ao nahe biti nas comunidades, é de se esperar que os PRCs tenham sido efetivos na reconciliação individual e comunitária. Cumpre frisar que, o nahe biti incorpora aspectos sacramentais e que o não respeito às decisões tomadas nesse âmbito, gera, no sistema de crenças timorense, uma punição por parte do divino e dos antepassados, tanto ao individuo quanto à comunidade. Nesse sentido, o cumprimento dos rituais e decisões impostos no processo do nahe biti são assumidos com naturalidade pelos participantes do processo.

Além da reconciliação individual e comunitária, também é preciso discutir a questão da reconciliação nacional, ou seja a recomposição das relações indivíduo-estado. 
Sob essa perspectiva é preciso analisar as causas da ruptura e propor reformas governamentais. As propostas devem levar em conta medidas que impeçam a ocorrência de novas violações e que asseguram a devida reparação àqueles que já tiveram seus direitos violados.

No caso de Timor-Leste, há sem dúvida uma necessidade de ressignificação do papel do estado, despindo-se do conceito opressor e que impõe valores e estruturas administrativas a favor do poder central. Embora o estado de Timor-Leste não tenha sido o principal perpetrador das violações ocorridas durante a ocupação, a questão central consiste na reformulação das relações entre estado e indivíduo, abandonando os conceitos e práticas autoritárias. É preciso empoderar os cidadãos, promovendo-se uma mudança de percepção e a transmissão de valores democráticos. Nesse aspecto a reforma institucional, enquanto elemento da justiça de transição, se entrelaça com a educação e formação de cidadãos.

Ao se debruçar sobre a reconciliação nacional em Timor-Leste, é de fundamental importância compreender-se a perspectiva da construção da identidade. Assim, reconciliação nacional deve ser entendida como um fenômeno de aproximação das comunidades, no sentido de forjar um senso de união nacional. Trata-se de reconciliar a nível nacional aqueles que lutaram na resistência e os defensores do estatuto da autonomia, que implicava a manutenção de Timor-Leste como província indonésia. Assim, os relatos comuns levam à uma soma de narrativas, que permitem refletir acerca do futuro que se pretende para o estado de Timor-Leste e como serão estabelecidas as futuras relações entre indivíduos, comunidade e estado.

A CAVR ao conduzir os PRCs, bem como as audiências públicos e através documentos produzidos guiou-se pelo o objetivo mais amplo de promoção dos direitos humanos. Ao fazê-lo considerou diversos aspectos que dizem respeito tanto às vítimas, quanto à coletividade como um todo. A narrativa produzida possibilitou a conciliação dos objetivos compreendidos em seu mandato, contribuindo para a reflexão acerca das violações de direitos humanos e da necessidade de combate à impunidade. Através de seu trabalho de busca da verdade, a CAVR tornou-se instrumento de efetivação dos direitos humanos e do combate à impunidade. 


\subsubsection{As contribuições da CAVR}

A CAVR alcançou mais do que os objetivos enunciados expressamente em seu instrumento de mandato, contribuindo também para o avanço das instituições democráticas, para a construção da identidade nacional e para a educação em direitos humanos

Sob o aspecto simbólico, a CAVR significou a abertura das instituições à participação da população. O paradigma autoritário no qual as instituições públicas eram conduzidas por militares, foi abandonado, democratizando-se o espaço público. Assim, os cidadãos passaram a ter um exemplo concreto de que podem integrar as instituições civis, participando de maneira ativa. Ademais, a CAVR ao documentar as violações e ao dar efetividade ao direito à verdade, demonstrou a necessidade assegurar a publicidade da atuação estatal. Assim, serviu e continua a servir como referencial no acesso à informação a respeito da atuação do estado, preceito essencial na formulação democrática. Permitiu-se pela primeira vez, que os cidadãos fossem ouvidos e que fossem reconhecidos oficialmente os abusos a que foram submetidos.

A partir dos relatos das vítimas, foi possível construir uma identidade e uma história comum. Com efeito, conforme apontado, a identidade timorense resulta de uma construção que se inicia sobretudo, a partir da dominação indonésia e da exclusão sofrida pelos timorenses. Até então, os diversos reinos encontravam-se fragmentados e isolados. Somente apos a invasão indonésia é que começou-se a articular uma identidade nacional em sentido amplo. A esse respeito da construção da nacionalidade cumpre retomar Zygmunt Bauman, que afirma: “a 'naturalidade' do pressuposto de que 'pertencer-pornascimento' significava, automática e inequivocamente, pertencer a uma nação foi uma convenção arduamente construída - a aparência de 'naturalidade' era tudo, menos natural.

Diferentemente a 'minisociedades' de familiaridade mútua...". ${ }^{223}$ Assim, a construção da ideia de nação como vínculo de identidade não nasce naturalmente.

De maneira que a construção da identidade timorense não difere substancialmente dos processos enfrentados quando da criação dos primeiros estados nacionais, nos moldes ocidentais. O que o torna um fenômeno peculiar é o fato de que em pleno século XXI, pode-se observar esse fenômeno de construção da identidade nacional, em uma era marcada cada vez mais pela ausência de fronteiras e pela interação de diferentes grupos. A

${ }^{223}$ BAUMAN, Zygmunt. Identidade. Rio de Janeiro: Zahar, 2005, p. 29. 
construção da identidade timorense se desenvolve em um época de acentuação das dicotomias em torno das culturas locais e o cosmopolitismo.

Para além do papel de reforma institucional e de construção da identidade nacional, é possível verificar-se ainda o papel educativo que a CAVR continua a ter mesmo dez anos após a conclusão de seus trabalhos. Com efeito, todo o trabalho desenvolvido atua como referência na promoção dos direitos humanos demonstrando ser possível, mesmo diante da fragilidade do pós-conflito garantir e respeitar esses direitos. Os documentos produzidos, também possibilitarem um registro histórico dos acontecimentos, que até então encontravam-se apenas inscritos nas lembranças daqueles que viveram durante o período. Assim, o trabalho levado à cabo pela CAVR constitui um importante material na educação pra direitos humanos para as futuras gerações.

Com efeito, os trabalhos da CAVR demonstram a atualidade de algumas questões centrais. Algumas práticas e violações identificadas no relatório foram herdadas e permaneceram na sociedade, mesmo após a independência, como por exemplo a violência de gênero. Segundo o relatório:

Em Timor-Leste, o conflito criou condições limitativas das liberdades das
mulheres e raparigas, também especialmente vulneráveis às violações dos
direitos humanos. Entre essas violações refiram-se a violação, a escravidão
sexual e outras formas de violência sexual que, embora sobretudo
perpetradas pelo aparelho de segurança indonésio, também implicou vários
homens timorenses. As mulheres vítimas de violência sexual foram
frequentemente ostracizadas pela sua comunidade, aumentando a sua
vulnerabilidade a novas violações. Algumas continuam a ser vitimizadas na
atualidade devido à experiência que viveram....

Diante do quadro relatado a CAVR fez recomendações no sentido de desenvolver políticas a fim de superar a violência de gênero. No entanto, as práticas identificadas no relatório continuam a ser uma problemática atual e as recomendações verdadeiros desafios. De maneira que o relatório não apenas atua como referencial em relação ao passado de Timor-Leste, mas também é uma importante contribuição na análise dos problemas atuais, uma vez que o fim do regime militar e a independência do país, não significaram o fim dos abusos e elementos do autoritarismo. Não se faz aqui uma comparação de regimes, mas chama-se a atenção para o fato de que violações de direitos humanos não deixam de ser um questão central apenas com a mudança para o regime democrático. Ao contrário, algumas práticas se perenizam e devem, portanto ser combatidas. Isso porque a mudança de mentalidade - ao contrário da mudança de regime, que se caracteriza por uma ruptura - 
depende de um processo de formação e transformação da sociedade e da cultura.

4.1.7 As Forças de Defesa e os Serviços de Polícia desenvolvam políticas públicas firmes e aplicáveis destinadas a promover a igualdade entre sexos, a ilegalizar a exploração sexual e a violência contra as mulheres e a impor sanções tão firmes quanto possível contra os membros das forças de segurança culpados de infração destas políticas, de maneira que jamais as mulheres de Timor-Leste tenham de sentir medo dos agentes encarregados de proteger e defender os seus direitos.

Sob tal perspectiva, para além do esforço de documentação e reconciliação, a maior contribuição da CAVR só pode ser observada a partir do distanciamento temporal de seus trabalhos. Nesse sentido, dez anos após a divulgação do relatório Chega!, revela-se ainda como uma referência para o desenvolvimento de políticas e instituições em TimorLeste para promoção e respeito aos direitos humanos. 


\section{CONCLUSÃO}

Essencialmente procurou-se apontar que a justiça de transição é tema que vem ocupando lugar de destaque nas últimas décadas, expandindo-se e incorporando dimensões cada vez mais complexas, a medida em que a realidade evidencia os laços sinérgicos entre questões como direitos humanos, desenvolvimento e democracia. No contexto da justiça de transição e, especialmente em decorrência das discussões acerca do crime desaparecimento forçado de pessoas, verifica-se a emergência do direito à verdade. De acordo com o relatório da Comissão Interamericana sobre direito à verdade: "particularmente em contextos transicionais, alcançar uma verdade completa, veraz, imparcial e socialmente construída é um elemento fundamental para a reconstrução da confiança cidadã na institucionalidade estatal". ${ }^{224}$ Dessa forma, a afirmação do direito à verdade têm recebido grande atenção na esteira das democratizações das últimas décadas e da proliferação de comissões da verdade, embora ainda haja um grande debate em torno de sua autonomia.

Inicialmente o direito à verdade foi reconhecido como um direito individual das vítimas e familiares em se ter notícias a respeito do desaparecimento forçado de pessoas em situações de conflito. Com efeito, o direito à verdade surge como um mecanismo de combate à impunidade. Em razão disso, as vítimas possuem um papel central. $\mathrm{O}$ direito à verdade constitui-se, assim, num direito individual de satisfação. Nesse contexto, a atividade das cortes regionais foi fundamental para o avanço e reconhecimento do direito das vítimas e familiares. A Corte Interamericana de Direitos Humanos teve uma atuação pioneira nesse sentido, e foi logo seguida pela Corte Europeia de Direitos Humanos e posteriormente pelo recém criado Tribunal Africano de Direitos Humanos e dos Povos.

A evolução dessa noção passou a incorporar toda a gama de violações de direitos humanos, ocultada pela ação estatal. Assim, o direito à verdade passou então a ser uma temática da justiça de transição, uma vez que a passagem para a democracia sinalizava a necessidade de elucidação dos crimes cometidos em regimes autoritários.

Contudo, o direito à verdade não se circunscreve a contextos transicionais e também não se limita mais a um direito relacionado a situações de conflito armado. Em uma acepção ampla o direito à verdade consiste no acesso às informações, no conhecimento dos fatos e no reconhecimento pelo estado de suas ações. Assim, também se

224 CIDH. Derecho a la verdade en América, 2014, p. 20. Disponível em: $<$ http://www.oas.org/es/cidh/informes/pdfs/Derecho-Verdad-es.pdf> Acesso em: 06.12.2014. 
revela como um elemento central à sobrevivência dos regimes democráticos. Sob essa perspectiva, implica a prestação de satisfação do estado à população e na garantia de transparência.

A dicotomia existente entre verdade e mentira e verdade e segredo permeia toda a formulação política. Enquanto a mentira é a alteração deliberada dos fatos, o segredo consiste na separação entre aqueles que têm acesso às informações e aqueles que não as tem. A partir dessa distinção, o conceito de direito à verdade se desdobra e consiste tanto na não alteração das verdades factuais, quanto na revelação dos acontecimentos e na admissão pelo estado de violações de direitos humanos.

Conforme assinala Sissela Bok, o segredo de estado nem sempre é prejudicial, justificando-se muitas vezes. $^{225}$ Ocorre que, a utilização do segredo deve ser cuidadosamente limitada. Assim, não pode ser presumida. Ao contrario, só pode ser admitida em circunstâncias excepcionais. Partindo-se de tal análise é forçoso concluir que o segredo não se justifica em situações de violações de direitos humanos, prevalecendo o direito à verdade.

Os estudos e a jurisprudência mais recentes apontam em direção ao reconhecimento do direito à verdade também em sua dimensão coletiva. Como direito coletivo, a verdade deve ser entendida como pressuposto para construção do estado democrático de direito. Assim, a representatividade torna imprescindível a transparência estatal e a verificação de responsabilidades.

A emergência e reconhecimento do direito à verdade foram abordados sob a perspectiva histórica do desenvolvimento dos direitos humanos. Mas, conforme pensamento de Norberto Bobbio é indispensável que o direito se debruce, não apenas sobre as questões teóricas, mas também sobre as questões de práticas relacionadas à efetivação dos direitos humanos.

O direito à verdade, assim, pode ser implementado através de diversos instrumentos, como a desclassificação de documentos, por exemplo. Nesse contexto, as comissões da verdade constituem importante mecanismo no estabelecimento da verdade, mas não esgotam as medidas necessárias para que se assegure esse direito. As comissões da verdade são especialmente importantes nos contextos transicionais, mas podem também ser estabelecidas em outras situações. ${ }^{226}$

\footnotetext{
${ }^{225}$ BOK, Sissela. Secrets - On the Ethics of Concealment and Revelation. New York: Vintage Books, 1989.

${ }^{226}$ A Comissão para Verdade e Reconciliação do Canadá, responsável por apurar violações aos direitos dos povos nativos, é uma referencia nesse sentido.
} 
A CAVR foi paradigmática, pois conseguiu realizar um detalhado registro histórico dos acontecimentos, ao mesmo tempo em que envolveu toda a população de Timor-Leste, através dos PRCs. Alguns elementos marcantes e que influenciaram decisivamente nos trabalhos da CAVR devem ser mencionados, como: a tradição oral dos idiomas locais, o caráter segmentado da sociedade e a valorização da família e da comunidade em relação ao indivíduo.

A fragilidade institucional e a cultura da violência, que tipicamente caracterizam as sociedades pós-conflito trouxeram consigo enormes desafios à CAVR, que ainda sim realizou um trabalho admirável, servindo como referência ao estudo da justiça de transição. Em essencial, a CAVR imprimiu efetividade aos direitos humanos como um todo ao garantir o direito à verdade, contribuindo assim, não apenas para a satisfação das vítimas, mas também para a sociedade como um todo. A CAVR ao estabelecer um registro dos acontecimentos e promover os processos de reconciliação, foi além ao contribuir para a construção da identidade nacional e para a edificação de instituições democráticas. Ademais, teve um papel pedagógico ao produzir material que permite traçar os limites da atuação estatal. Suas recomendações são atuais, no sentido de que permanece ainda um longo caminho a ser trilhado para a realização dos direitos humanos e para a garantia da responsabilidade.

O recorte teórico adotado para esta análise permite identificar de que maneira o direito à verdade pode ser implementado e sua relação com outros elementos da justiça de transição. Ademais, aponta no sentido de que o direito à verdade não apenas possui uma dimensão individual, mas permeia toda a construção do espaço público, consubstanciandose na garantia de acesso à informação. Contudo, quando num contexto de violações de direitos humanos, o direito à verdade se insere no combate à impunidade, devendo ser alinhado aos demais preceitos envolvidos. Assim: "a partir de uma perspectiva de direitos humanos, o dever de investigar e processar resulta do direito ao remédio efetivo. $\mathrm{O}$ direito à verdade da vítima, de seus parentes, e em algumas circunstâncias, da sociedade, integra esse direito ao remédio". 227

Portanto, é preciso assegurar que paralelamente ao direito à verdade, seja garantida também a devida responsabilização e a reparação pelas violações de direitos humanos, estabelecendo-se assim uma relação de complementariedade sinérgica. Conforme assinala Hannah Arendt a respeito da relação entre verdade factual e

${ }^{227}$ ONU. Human Rights Council. Report of the Special Rapporteur on the promotion of truth, justice, reparation and guarantees of non-recurrence. A/HRC/27/56, de 27.08.2014. p. 6. 
julgamento: "nenhuma discussão da responsabilidade individual faria muito sentido sem um conhecimento preciso do pano de fundo factual". ${ }^{228}$

${ }^{228}$ ARENDT, Hannah. Responsabilidade e julgamento. São Paulo: Companhia das Letras, 2004, p. 106. 


\section{BIBLIOGRAFIA}

Livros, artigos e relatórios

AMBOS, Kai. A parte geral do direito penal internacional: Bases para uma elaboração dogmática. São Paulo: Editora Revista dos Tribunais, 2008.

ANDERSON, Benedict. Imaginar Timor-Leste. Tradução de Osvaldo M. Silvestre. In: Arena Magazine 4, Abril-Maio 1993.

ARENDT, Hannah. A condição humana. Rio de Janeiro: Forense Universitária, $10^{\mathrm{a}}$ ed. 2008 .

. Crises da República. São Paulo: Perspectiva, $2^{\mathrm{a}}$ ed. 2004.

. As origens do totalitarismo. São Paulo: Companhia das Letras, 2012.

. Entre o passado e o futuro. São Paulo: Perspectiva, 11 a ed. 2011.

. Responsabilidade e julgamento. São Paulo: Companhia das Letras,

2004.

ARRIAZA, Naomi Roht (ed). Impunity and Human Rights in International Law Practice. New York: Oxford University Press, 1995.

BASSIOUNI, Cherif. A Functional Approach to General Principles of International Law. Spring, 1990.

Review. 62, 2006.

. International Recognition of Victims Rights. In: Human Rights Law

$3^{\mathrm{a}}$ ed. 2008.

. International Criminal Court. Leiden: Martinus Nijhoff Publishers,

BAUMAN, Zygmunt. Identidade. Rio de Janeiro: Zahar, 2005.

BELTRAMI, Priscila A. A eficácia do acesso à justiça e a reconstrução institucional em regiões pós-conflito: contribuição ao merco teórico da reconstrução de sistemas de justiça. Dissertação (Mestrado em Direito) - Faculdade de Direito, Universidade de São Paulo, São Paulo, 2011.

BENEDETTI, Juliana Cardoso. Tão próximos, tão distantes: a justiça restaurativa entre comunidade e sociedade. Dissertação (Mestrado em Direito) - Faculdade de Direito, Universidade de São Paulo, São Paulo, 2009.

BERMAN, Harold J. Direito e revolução, a formação da tradição jurídica ocidental. São Leopoldo: Unisinos. 
BOBBIO, Norberto. A era dos direitos. Rio de Janeiro: Elsevier, 2004.

BOK, Sissela. Secrets - On the Ethics of Concealment and Revelation. New York: Vintage Books, 1989.

CASSESE, Antonio. The Contribution of the International Criminal Tribunal for Former Yugoslavia to the ascertainment of general principles of law recognized by the community of nations. In: S. Yee et all (orgs.).International Law in the Post-Cold War World: Essays in Memory of Li Haopi. London: Routledge, 2001.

CAVR. Chega! 2005. Disponível em: <http://www.cavrtimorleste.org/po/Relatorio\%20Chega!.htm> Acesso em: 23.06.2013.

COHEN, David. Intended to Fail - The Trials before the Ad Hoc human Rights Court in Jakarta.Berkeley, 2003. Disponível em $<\mathrm{http} / / /$ socrates.berkeley.edu/ warcrime/Papers/IntendedtoFail.pdf $>$ Acesso em: 07.03.2012.

COMISSÃO AFRICANA DE DIREITOS HUMANOS E DOS POVOS. Principles and Guidelines on the Right to a Fair Trial and Legal Assistance in Africa, 2003.

COMISSÃO INTERAMERICANA DE DIREITOS HUMANOS. Derecho a la verdade en América, 2014. Disponível em: <http://www.oas.org/es/cidh/informes/pdfs/DerechoVerdad-es.pdf> Acesso em: 06.12.2014.

COMPARATO, Fabio K. A afirmação histórica dos direitos humanos. São Paulo: Saraiva, 2010

COOPER, John M. (org). Plato Complete Works. Indianapolis: Hackett Publishing Company, 1997.

COTTON, James. East Timor, Australia and Regional Order Politics.In: Asia Series. London School of Economics, 2004.

CTF. Per Memoriam Ad Spem - Final Report. 2008, p. V. Disponível em: $<\mathrm{http}$ ://www.cja.org/downloads/Per-Memoriam-Ad-Spem-Final-Reeport-of-the-

Commission-of-Truth-and-Friendship-IndonesiaTimor-Leste.pdf $>$ Acesso em: 07.09.2014.

CTR. Truth and Reconciliation Committee Final Report. 2003. Disponível em: $<$ http://www.justice.gov.za/trc/report/>Acesso em: 07.09.2014.

CUNHA, João Solano Carneiro de. A questão do Timor-Leste: origens e evolução. Brasília: Instituto Rio Branco, 2001. Disponível em $<$ http://www.funag.gov.br/biblioteca/index.php?option=com_docman\&task=doc_details\& gid=390\&Itemid=41> Acesso em: 07.03.2012.

DELMAS-MARTY, Mireille. Le champs pénal. In: Mélanges en l'honneur du professeur Reynald Ottenhof. Paris: Dalloz. 
. Le droit penal comme éthique de la mondialisation. In: Annales Internacionales de Criminologie. v. 41, n.1-2, 2003.

DERRIDA, Jacques. On Cosmopolitanism and Forgiveness. New York: Routledge, 2006.

DINIZ, Debora. Antropologia e os limites dos direitos humanos: o dilema moral. . In: NOVAES, Regina Reyes, LIMA, Roberto Kant de (Org.). Antropologia e direitos humanos. Niterói: Editora da Universidade Federal Fluminense, 2001. 17-46 p.

DUMBERRY, Patrick. New State Responsibility for Internationally Wrongful Acts by an Insurrectional Movement. In: The European Journal of International Law. v. 17 no.3, 2006, p. 605-621.

ELLIS, Mark S. HUTTON, Elizabeth. Policy Implications of World War II Reparations and Restitution as Applied to the Former Yugoslavia. In: Berkeley Journal of International Law, v. 20, 2002, p. 342-354. Disponível em: $<\mathrm{http}$ //scholarship.law.berkeley.edu/cgi/viewcontent.cgi?article $=1218 \&$ context $=$ bjil $>$ Acesso em: 07.09.2014.

ELSTER, Jon. Closing the books - Transitional justice in historical perspective. Cambridge: Cambridge University, 2004.

FINNIS, John. Natural Law \& Natural Rights. New York: Oxford University Press, 2011.

FORGANES, Rosely. Queimado queimado, mas agora nosso! Timor: das cinzas à liberdade. São Paulo: Labortexto Editorial, 2002.

FUKUYAMA, Francis. The Origins of Political Order.London: Profile Books, 2012.

GAUER, Ruth M. Chittó, SAAVEDRA, Giovani Agostini, GAUER, Gabriel J. Chittó. Memória, punição e justiça: uma abordagem interdisciplinar. Porto Alegre: Livraria do advogado, 2011.

GONZÁLES, Eduardo. Drafting a Truth Commission Mandate. A Practical Tool. ICTJ, 2013. Disponível em: <http://ictj.org/sites/default/files/ICTJ-Report-DraftingMandateTruth-Commission-2013_0.pdf $>$ Acesso em: 13.06.2013.

GONZALEZ-SALZBERG, Daimián. El derecho a la verdade en situaciones de postconflicto bélico de carácter no-internacional. In: Revista Colombiana de Derecho Internacional, n.12, p. 435-468, 2008. Disponível em: $<$ http://www.scielo.org.co/pdf/ilrdi/n12/n12a16.pdf> Acesso em 01.12.2014.

GORDON, Joana Zühlsdorff de Paiva. Sobre a verdade, a mentira - entre a justiça e a política. Dissertação (Mestrado em Direito) - Faculdade de Direito, Universidade de São Paulo, São Paulo, 2008.

GORJÃO, Paulo. Mudança de regime e política externa: Portugal, Indonésia e o destino do Timor-Leste. In: Análise Social. v. XI (174), 2005, p. 7-35. Disponível em: $<$ http://www.scielo.oces.mctes.pt/pdf/aso/n174/n174a01.pdf $>$ Acesso em: 08.03.2012. 
GROOME, Dermot. The Right to Truth in the Fight against Impunity. In: Berkeley Journal of International Law. 175, v. 29, 2011. Disponível em: $<$ http://scholarship.law.berkeley.edu/cgi/viewcontent.cgi?article=1401\&context=bjil $>$ Acesso em: 20.11.2014.

HEYNER, Priscilla B. Unspeakable Truths. New York: Routledge, 2a ed, 2002.

HEYNES, CRISTOF. A “Struggle Approach" to Human Rights. In: HEYNES, CRISTOF; STEFISZYN, KAREN (edit). Human Rights, Peace and Justice in Africa: a Reader. Pretoria: Pretoria University Law Press, 2006, p. 15-35. Disponível em: $<$ http://www.pulp.up.ac.za/pdf/2006_05/2006_05.pdf> Acesso em: 09.10.2014.

HINTON, Alexandra Laban. Transitional Justice. London: Rutgers University Press, 2011

HIRST, Megan. An Unfinished Truth: An Analysis of The Commission of Truth and Friendship's Final Report on the 1999 Atrocities in East Timor. ICTJ, 2009. Disponível em $\quad<$ http://ictj.org/publication/unfinished-truth-analysis-commission-truth-andfriendships-final-report-1999-atrocities> Acesso em: 29.02.2012.

HONNA, Jun. Military Politics and democratization in Indonesia. London: Routledge, 2005.

HUMAN RIGHTS WATCH. Justice Denied for East Timor. Disponível em: $<$ http://www.hrw.org/legacy/backgrounder/asia/timor/etimor1202bg.htm> Acesso em: 02.09.2014.

HUNTINGTON, Samuel. O choque das civilizações. Rio de Janeiro: Objetiva, 1997.

ICTJ. Challenging the Conventional: Can truth Commissions Strengthen Peace Processes? Jun 2014, tradução livre. Disponível em: <http://www.ictj.org/publication/challengingconventional-can-truth-commissions-strengthen-peace-processes> Acesso em: 06.12.2014.

Country case study: Timor-Leste - Security Sector Reform in Timor-Leste.2009. Disponível em: <https://www.ictj.org/sites/default/files/ICTJ-IFP-TimorLeste-SecurityReform-2009-English.pdf $>$ Acesso em: 29.11.2014.

. The Legal Mandate of a Truth Commission: Objectives, Functions, Competence, and Powers.Disponível em: <http://ictj.org/sites/default/files/ICTJ-Book-Truth-SeekingChapter4-2013-English.pdf $>$ Acesso em: 20.05.2013.

Transitional Justice in the United Nations Human Rights Council.Jun de 2011. Disponível em: <http://www.ictj.org/publication/transitional-justice-united-nations-humanrights-council> Acesso em: 01.09.2014.

. Unfulfilled Expectations: Victims' perceptions of justice and reparations in TimorLeste. 2010. Disponível em: <http://www.ictj.org/sites/default/files/ICTJ-TimorLesteUnfulfilled-Expectations-2010-English.pdf> Acesso em: 05.09.2014.

KATZENSTEIN, Sauzanne. Hybrid Tribunals: Searching for Justice in East Timor. In: Harvard Human Rights Journal.v.16, Cambridge, 2003. 
Disponívelem $<$ http://www.law.harvard.edu/students/orgs/hrj/iss16/katzenstein.pdf $>$ Acesso em 08.03.2012.

LAFER, Celso. Experiência, ação e narrativa: reflexões sobre um curso de Hannah Arendt. In: Revista de Estudos Avançados da Universidade de São Paulo. vol.21 no.60, São Paulo May/Aug. $2007 . \quad$ Disponível em: $<$ http://www.scielo.br/scielo.php?pid=S0103-40142007000200022\&script=sci_arttext> Acesso em: 20.082014.

ed. 2006. . A reconstrução dos direitos humanos. São Paulo: Companhia das letras, $6^{\mathrm{a}}$ . A ruptura totalitária e a reconstrução dos direitos humanos - um diálogo com Hannah Arendt. 1988. Tese (Titularidade) - Faculdade de Direito, Universidade de São Paulo, São Paulo, 1988.

. Hannah Arendt - Pensamento, persuasão e poder. São Paulo: Paz e Terra. 2003.

LINTON, Suzannah. Unraveling the First Three Trials at Indonesia's AdHoc Court for Human Rights Violations in East Timor. In: Leiden Journal of International Law. v. 17, 2004, 303-361 p. Disponível em: $<$ http://journals.cambridge.org/action/displayFulltext?type=1\&pdftype=1\&fid=234266\&ji $\mathrm{d}=\mathrm{LJL} \&$ volumeId=17\&issueId=02\&aid=234265> Acesso em: 27.02.2012.

LORENCINI, Marco Antonio Garcia Lopes. Prestação jurisdicional pelo estado e meios alternativos de solução de controvérsias: convivência e formas de pacificação social. Tese (Doutorado) - Faculdade de Direito, Universidade de São Paulo, São Paulo 2006.

MAGARRELL, Lisa. Reparations in Theory and Practice.New York: ICTJ, 2007. Disponível em: <http://ictj.org/sites/default/files/ICTJ-Global-Reparations-Practice-2007English.pdf> Acesso em: 20.09.2014.

MCAULIFFE, Padraig. UN peace-building, transitional justice and the rule of law in East Timor: the limits of institutional responses to political questions. In: Netherlands International Law Review. LVIII: 103-135, 2011. Disponível em: $<$ http://journals.cambridge.org/action/displayFulltext?type $=1 \&$ pdftype $=1 \&$ fid $=8266562 \&$ j $\mathrm{id}=\mathrm{NLR} \&$ volumeId=58\&issue $\mathrm{Id}=01 \&$ aid $=8266561>$ Acesso em: 12.02 .2012 .

MELLO, Celso. Direito penal internacional e direito internacional penal. Rio de Janeiro, 1978.

MENDEZ, Juan E. Accountability for Past Abuses. In: Human Rights Quarterly. The John Hopkins University Press. 19.2, 1997, p. 255-282.

MENDONÇA, Andrey Borges de. $O$ direito à memória: uma análise de seu conteúdo e efetividade no contexto brasileiro. Dissertação (Mestrado) - Faculdade de Direito, Universidade Pablo de Olavide, Sevilha, 2009. 
MOEKLI, Daniel, SHAH, Sangreeta, SIVAKUMARAN, Sandesh. International Human Rights. Oxford: Oxford University Press, 2010.

MORE, Jina. Truth Commissions. In: Issues in Peace and Conflict Studies. Thousand Oaks: Sage, $317-340 \mathrm{p}$.

MORE, Rodrigo Fernandes. Fundamentos das operações de paz das nações unidas e a questão do Timor-Leste. Dissertação (Mestrado)- Faculdade de Direito, Universidade de São Paulo, São Paulo, 2002.

NAQVI, Yasmin. The Right to the Truth in International Law: Fact or Fiction? In: International Review of the Red Cross. v. 88, n. 862, jun 2006.

ONU. Carta do Secretário Geral da ONU endereçada ao Conselho de Segurança. S/2005/96 Disponível em: $\quad<$ http://daccess-ddsny.un.org/doc/UNDOC/GEN/N05/243/59/PDF/N0524359.pdf?OpenElement> Acesso em: 02.09.2014.

- Commission for Human Rights on Civil and Political Rights. Questions of disappearances and summary executions - Report of the Working Group on Enforced or Involuntary Disappearances. E/CN.4/2006/56 de 27 de dezembro de 2005. Disponível em: $<$ http://daccess-dds-

ny.un.org/doc/UNDOC/GEN/G05/168/77/PDF/G0516877.pdf?OpenElement> Acesso em: 11.09.2014.

. Human Rights Council. Report of the Special Rapporteur on the promotion of truth,

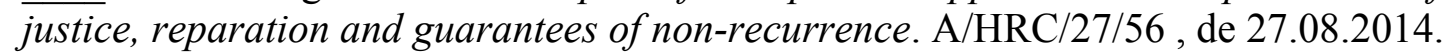

. Office of the High Commissioner for Human Rights. Analytical Study on Human

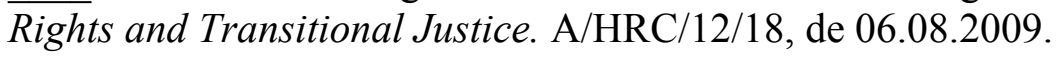

. Office of the High Commissioner for Human Rights. Analytical Study on Human Rights and Transitional Justice, Activities Undertaken by the Human Rights Components of the United Nations System. E/CN.4/2006/93, de 07.02.2006.

. Office of the High Commissioner for Human Rights. Human rights and Transitional Justice. A/HRC/18/23, de 04.06.2011.

. Office of the High Commissioner for Human Rights. Report on the Right to Truth. $\overline{\mathrm{E} / \mathrm{CN}} .4 / 2006 / 91$ de 08.02.2006.

Office of the High Commissioner for Human Rights. Report on the Right to Truth. A/HRC/5/7, de 07.06.2007.

Office of the High Commissioner for Human Rights. Report on the Right to the Truth. A/HRC/12/19 de 21.08.2009.

. Office of the High Commissioner for Human Rights. Report on Right the Right to the Truth. A/HRC/15/33, de 28.07.2010. 
. Secretary General. Report on the Rule of Law and Transitional Justice in Conflict and Post-conflict Societies. Ago de 2004. Disponível em: $<$ http://www.unrol.org/files/2004\%20report.pdf> Acesso em 01.09.2014.

Secretary General. Report on the United Nations Integrated Mission in Timor-Leste (for the period from 20 September 2011 to 6 January 2012) de 18.01.2012. Disponível em: $<$ http://www.un.org/ga/search/view_doc.asp?symbol=S/2012/43> Acesso em 08.03.2012.

_. Secretary General. United Nations Approach to Transitional Justice, Guidance note. 2010. Disponível em: $<$ http://www.unrol.org/files/TJ_Guidance_Note_March_2010FINAL.pdf $>$ Acesso em: 11.09.2010.

.UNDP. Human Development Report 2013.The Rise of the South: Human Progress in a diverse World.2013. Disponível em: $<$ http://hdr.undp.org/en/media/HDR2013_EN_Summary.pdf $>$ Acesso em: 25.05.2013.

PERRONE-MOISÉS, Claudia. Antecedentes históricos do estabelecimento do Tribunal Penal Internacional. In: Revista da Faculdade de Direito da Universidade de São Paulo, São Paulo, vol. 98, 2003. p. 574-575.

. Direito internacional penal. Barueri: Manole, 2012.

. Imunidades de chefes de Estado e crimes internacionais. Tese (Livre Docência) - Faculdade de Direito, Universidade de São Paulo, São Paulo, 2009.

"desaparecimentos" e direito à verdade. In: Piovesan, Flavia (org.). Direitos humanos, globalização econômica e integração regional, São Paulo: Max Limonad, 2002, p. 285205

. O perdão e os crimes contra a humanidade: um diálogo entre Hannah Arendt e Jacques Derrida. In: CORREIA, Adriano (Org). Hannah Arendt e a condição humana. Quarteto.

PERRUSO, Camila Akemi. O desaparecimento forçado de pessoas no sistema Interamericano de Direitos Humanos - direitos humanos e memória. Dissertação (Mestrado em Direito) - Faculdade de Direito, Universidade de São Paulo, São Paulo, 2010.

POLLAK, Michael. Memória, esquecimento, silêncio. In: Estudos Históricos. Rio de Janeiro, vol.2, n.3, 1989. 3-15 p.

QUINALHA, Renan Honório. Justiça de transição: contornos do conceito. São Paulo: Outras Expressões, 2013.

RAMOS, André de Carvalho. Responsabilidade Internacional por violação de Direitos Humanos: seus elementos, a reparação devida e as sanções possíveis: teoria e prática. Rio de Janeiro: Renovar, 2004. 
REIGER, Caitlin, WIERDA, Marieke. The Serious Crimes Process in Timor-Leste: In Retrospect. Internacional Centre for Transitional Justice. 2006. Disponível em: $<$ http://www.ictj.org/sites/default/files/ICTJ-TimorLeste-Criminal-Process-2006English.pdf $>$ Acesso em: 20.09.2014.

RICOEUR, Paul. A memória, a história, o esquecimento. Campinas: Editora Unicamp, 2007.

ROSSI, Paolo. O passado, a memória, o esquecimento. São Paulo: UNESP, 2010.

ROTH-ARRIAZA, Naomi. MARIEZCURRENA, Javier. Transitional Justice in theTwenty-FirstCentury - BeyondTruth versus Justice. Cambridge: Cambridge University Press, 2006.

SANTOS, Boaventura de Sousa. Direitos Humanos: o desafio da interculturalidade.In: Revista Direitos Humanos. v. 02, jun de 2009.

SEBASTIAN, Leonard C. Realpolitik Ideology Indonesia's Use of Military Force. Singapore: Institute of Southeast Asian Studies, 2006.

SEN, Amartya. Desenvolvimento como liberdade. São Paulo: Companhia das Letras, 2012.

SHAFFER, Matthew Shaffer. An Arendtian Analysis of the Truth and Reconciliation Commission. In: The Yale Review of International Studies, volume 03, 2012. Disponível em: <http://yris.yira.org/essays/833> Acesso em 12.02.2013.

SILVA, Kelly. As nações (des)unidas. Práticas da ONU e a construção do Estado em Timor-Leste.

SIMIÃO, Daniel Schroeter. Sensibilidade jurídica e diversidade cultural: dilemas timorenses em perspectiva comparada. In: SILVA, Kelly; SOUZA, Lúcio (orgs.). Ita maunalin: o livro do irmão mais novo. Lisboa: Edições Colibri, 2011.

SOARES, Dionísio. Nahe Biti: The Philosophy and Process of Grassroots Reconciliation (and Justice) in East Timor. In: The Asia Pacific Journal of Anthropology. v. 5, n.1, abril, 2004, p. 15-33.

SOARES, Inês Virgínia Prado. KISHI, Sandra Akemi Shimada (org.). Memória e verdade: A justiça de transição no estado democrático brasileiro. Belo Horizonte: Fórum, 2009.

STEINER, Henry J., ALSTON, Philip. International Human Rights in Context. New York: Oxford, 2000.

TEITEL, Ruti G..Transitional Justice Genealogy. In: Harvard Human Rights Journal, vol. 16, p. 69 - 85. Disponível em: <http://www.hcdh-togo.org/documentation/hcdh26082011151336-tjgenealogy.pdf> Acesso em: 30.08.2014.

TELES, Edson. Brasil e África do Sul: os paradoxos da democracia. Memória politica em democracias com herança autoritária. Tese (Doutorado em Direito) - Faculdade de Direito, Universidade de São Paulo, São Paulo, 2010. 
VAN DER MERWE, Hugo. BAXTER, Victoria. CHAPMAN, Audrey R. Assessing the Impact of Transitional Justice. Washington: United States Institute of Peace, 2009.

WIEBELHAUS-BRAHM, Eric. Truth commissions and Transitional Societies - The Impact on Human Rights and Democracy. New York: Routledge, 2010.

WILLIAMS, Bernard. Truth and Truthfulness. Princeton: Princeton University press, 2002 .

YOUNG-BRUEHL. Elisabeth. Why Arendt matters. New Haven: Yale University Press, 2006.

Sites

CAVR. Disponível em: <http://www.cavr-timorleste.org/po/home.htm> Acesso em: 23.06.2012.

CEDH. Disponível em: http://www.echr.coe.int/Pages/home.aspx?p=home $>$ Acesso em 01.12.2014.

CIDH. Disponível em: <http://www.corteidh.or.cr> Acesso em: 01.12.2014

CONSELHO DE DIREITOS HUMANOS DA ONU. Disponível em: $<$ http://www.africancourt.org/pt/> Acesso em 01.12.2014

CTF. Disponível em: <http://www.ctf-ri-tl.org/terms-of-reference/> Acesso em: 07.03.2012.

ICTJ. Disponível em: <ww.ictj.org> Acesso em 01.12.2014.

TADHP. Disponível em: http://www.african-court.org/pt/. Acesso em: 01.12.2014

UNMIT. Disponível em:

$<$ http://unmit.unmissions.org/Default.aspx?tabid=156\&ctl=Details\&mid=456\&ItemID=16 461>Acesso em : 07.03.2012.

UNTAET. Disponível em:

$<$ http://www.un.org/en/peacekeeping/missions/past/etimor/etimor.htm> Acesso em: 01.12.2014.

WAR CRIMES STUDY CENTRE, Califórnia. Disponível em: $<$ http://socrates.berkeley.edu/ warcrime/ET.htm> Acesso em: 07.03.2012. 